\title{
Studies on the Synthesis of (-)-Gymnodimine.
}

\section{Subunit Synthesis and Coupling}

\author{
James D. White,* Laura Quaranta, and Guoqiang Wang \\ Department of Chemistry, Oregon State University, Corvallis, Oregon 97331-4003. \\ james.white@oregonstate.edu
}

\section{SUPPORTING INFORMATION}

Table of Contents

- General techniques

- Experimental procedures for 18, 19, 21, 22, 23, 24, 25, 26, 27, 29, $31,32,34,35,39,40,41,42,44,45,53,54,55,56,57,60,67$, $71,73,74,75,76,79,80,81$, and 82

- $\quad{ }^{1} \mathrm{H}$ and ${ }^{13} \mathrm{C}$ NMR spectra of 18, 19, 21, 22, 23, 24, 25, 26, 27, $29,31,32,34,35,39,40,41,42,43,44,45,55,56,57,61,62$, $65,71,73,74,75,76,79,80,81,82,83,84,89,90,92,93,94$, 95, and 98

- X-ray crystallographic data for $\mathbf{1 9}$

- X-ray crystallographic data for $\mathbf{6 1}$

- X-ray crystallographic data for 62

S167-S179

- X-ray crystallographic data for $\mathbf{7 4}$

S180-S185 


\section{Experimental Section}

General techniques: All reactions requiring anhydrous conditions were conducted in flamedried glass apparatus under an atmosphere of argon. THF and $\mathrm{Et}_{2} \mathrm{O}$ were freshly distilled from sodium benzophenone ketyl prior to use. DMSO and DMF were distilled from $\mathrm{CaH}_{2}$ at $15 \mathrm{~mm}$ Hg. $\mathrm{CH}_{2} \mathrm{Cl}_{2}$ was freshly distilled from $\mathrm{CaH}_{2}$, and toluene was distilled from molten sodium metal. Anhydrous $\mathrm{MeOH}$ was obtained by distillation from magnesium alkoxide and stored under argon over activated $4 \AA$ molecular sieves. Preparative chromatographic separations were performed on silica gel (35-75 $\mu \mathrm{m})$; reactions were followed by TLC analysis using silica plates with fluorescent indicator $(254 \mathrm{~nm})$ and visualized with a UV lamp, phosphomolybdic acid or 4hydroxy-3-methoxybenzaldehyde. All commercially available reagents were purchased and were typically used as supplied.

Melting points were recorded using open capillary tubes and are uncorrected. Optical rotations were measured at ambient temperature $\left(22{ }^{\circ} \mathrm{C}\right)$ on $\mathrm{CHCl}_{3}$ solutions with a polarimeter using a 1 $\mathrm{mL}$ capacity cell with $1 \mathrm{dm}$ path length. Infrared spectra were recorded using a thin film supported between $\mathrm{NaCl}$ plates or as a solid embedded in a $\mathrm{KBr}$ disc. ${ }^{1} \mathrm{H}$ and ${ }^{13} \mathrm{C}$ NMR spectra were recorded in Fourier transform mode at the field strength specified either on a $300 \mathrm{MHz}$ or a $400 \mathrm{MHz}$ spectrometer. Spectra were obtained on $\mathrm{CDCl}_{3}$ solutions in $5 \mathrm{~mm}$ diameter tubes; chemical shifts in ppm are quoted relative to the residual signals of chloroform $\left(\delta_{\mathrm{H}} 7.25 \mathrm{ppm}\right.$, or $\left.\delta_{\mathrm{C}} 77.0 \mathrm{ppm}\right)$. Multiplicities in the ${ }^{1} \mathrm{H}$ NMR spectra are described as: $\mathrm{s}=\operatorname{singlet}, \mathrm{d}=$ doublet, $\mathrm{t}=$ triplet, $\mathrm{q}=$ quartet, $\mathrm{m}=$ multiplet, $\mathrm{br}=$ broad; coupling constants are reported in Hz. For low (MS) and high (HRMS) resolution mass spectra ion mass/charge $(\mathrm{m} / \mathrm{z})$ ratios are reported as values in atomic mass units. 


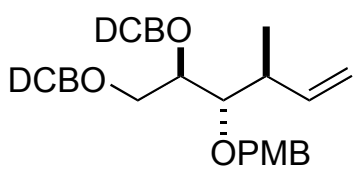

18

\section{(3S,4S,5R)-5,6-Bis-(2,6-dichlorobenzyloxy)-4-(4-methoxybenzyloxy)-3-methylhex-1-ene}

(18). To a suspension of $\mathrm{NaH}(1.15 \mathrm{~g}, 48 \mathrm{mmol})$ in dry DMF (100 mL) was added a solution of diol $17(3.25 \mathrm{~g}, 12 \mathrm{mmol})$ in dry DMF $(10 \mathrm{~mL})$ at $0{ }^{\circ} \mathrm{C}$. The mixture was stirred for $20 \mathrm{~min}$ at 0 ${ }^{\circ} \mathrm{C}$, and a solution of 2,6-dichlorobenzyl bromide $(11.5 \mathrm{~g}, 48 \mathrm{mmol})$ in dry DMF (20 mL) was added slowly, followed by $\mathrm{Bu}_{4} \mathrm{NI}(17.7 \mathrm{~g}, 48 \mathrm{mmol})$ at $0{ }^{\circ} \mathrm{C}$. The resulting mixture was stirred overnight at room temperature. The reaction was quenched by addition of saturated $\mathrm{NH}_{4} \mathrm{Cl}$ and the mixture was diluted with $\mathrm{Et}_{2} \mathrm{O}$. The phases were separated, and the organic layer was washed with water and brine. The solution was dried over $\mathrm{Na}_{2} \mathrm{SO}_{4}$, and concentrated under vacuum. Flash chromatography (hexane-EtOAc, 15:1) of the residue yielded $6.55 \mathrm{~g}(92 \%)$ of 18: $[\alpha]_{\mathrm{D}}^{23}+0.01\left(\mathrm{c} 0.77, \mathrm{CHCl}_{3}\right.$ ); IR (neat) 3073, 2959, 2878, 1613, 1583, 1564, 1514, 1436, 1249, 1197, 1098, 1037, 993, 916, 822, 767, $733 \mathrm{~cm}^{-1} ;{ }^{1} \mathrm{H}$ NMR (300 MHz, $\left.\mathrm{CDCl}_{3}\right) \delta 1.04(\mathrm{~d}, J$ $=7.0 \mathrm{~Hz}, 1 \mathrm{H}), 2.67(\mathrm{~m}, 1 \mathrm{H}), 3.53(\mathrm{dd}, J=3.9,7.7 \mathrm{~Hz}, 1 \mathrm{H}), 3.58(\mathrm{~m}, 1 \mathrm{H}), 3.79(\mathrm{~s}, 3 \mathrm{H}), 3.82(\mathrm{dd}$, $J=3.5,10.5 \mathrm{~Hz}, 1 \mathrm{H}), 4.01(\mathrm{dd}, J=3.2,10.5 \mathrm{~Hz}, 1 \mathrm{H}), 4.47(\mathrm{~d}, J=10.9 \mathrm{~Hz}, 1 \mathrm{H}), 4.59(\mathrm{~d}, J=$ $10.9 \mathrm{~Hz}, 1 \mathrm{H}), 4.80-5.0(\mathrm{~m}, 6 \mathrm{H}), 5.85(\mathrm{ddd}, J=8.5,11.1,16.6 \mathrm{~Hz}, 1 \mathrm{H}), 7.81(\mathrm{~m}, 2 \mathrm{H}), 7.12-$ $7.33(\mathrm{~m}, 8 \mathrm{H}) ;{ }^{13} \mathrm{C} \mathrm{NMR}\left(100 \mathrm{Mz}, \mathrm{CDCl}_{3}\right) \delta 18.6,40.0,55.7,66.4,68.1,69.5,74.7,79.9,82.1$, 114.0, 115.5, 129.7, 130.2, 131.6, 134.1, 134.2, 137.4, 137.4, 140.7, 159.2; HRMS (FAB) $\mathrm{m} / \mathrm{z}$ 583.0996 ([M+H]+; calcd for $\mathrm{C}_{29} \mathrm{H}_{31} \mathrm{O}_{4}{ }^{35} \mathrm{Cl}_{4}:$ 583.0977). 


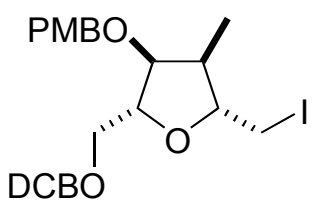

19

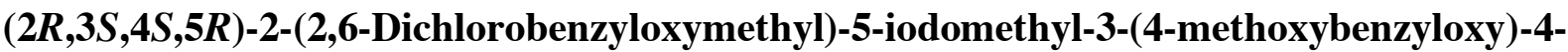

methyltetrahydrofuran (19). A solution of alkene $18(2.60 \mathrm{~g}, 4.40 \mathrm{mmol})$ in dry $\mathrm{CH}_{3} \mathrm{CN}(450$ $\mathrm{mL}$ ) was cooled to $-20{ }^{\circ} \mathrm{C}$ and a solution of iodine in dry $\mathrm{CH}_{3} \mathrm{CN}$ (34 mL of a $0.2 \mathrm{M}$ solution, 6.8 mmol) was added slowly via syringe. The dark-brown mixture was stirred for $3 \mathrm{~h}$ at $-20{ }^{\circ} \mathrm{C}$ and was diluted with $\mathrm{Et}_{2} \mathrm{O}$ and saturated $\mathrm{Na}_{2} \mathrm{~S}_{2} \mathrm{O}_{3}(50 \mathrm{~mL})$. The phases were separated and the aqueous phase was extracted with $\mathrm{Et}_{2} \mathrm{O}(200 \mathrm{~mL}$ x 2). The combined organic layer was washed with brine and dried over $\mathrm{Na}_{2} \mathrm{SO}_{4}$, filtered, and concentrated. Flash chromatography (hexaneEtOAc, 10:1) of the residue gave $2.10 \mathrm{~g}(87 \%)$ of 19: $[\alpha]_{\mathrm{D}}^{23}-35.8\left(\mathrm{c} 0.34, \mathrm{CHCl}_{3}\right)$; IR (neat) 2961, 2921, 2852, 1558, 1508, 1457, 1247, 1104, 1035, 812, $767 \mathrm{~cm}^{-1} ;{ }^{1} \mathrm{H}$ NMR (300 MHz, $\left.\mathrm{CDCl}_{3}\right) \delta 1.02(\mathrm{~d}, J=7.0 \mathrm{~Hz}, 3 \mathrm{H}), 1.99(\mathrm{~m}, 1 \mathrm{H}), 3.20(\mathrm{dd}, J=5.0,10.6 \mathrm{~Hz}, 1 \mathrm{H}), 3.43(\mathrm{dd}, J=$ 3.7, 10.6 Hz, 1H), $3.48(\mathrm{~m}, 1 \mathrm{H}), 3.49(\mathrm{dd}, J=7.0,9.9 \mathrm{~Hz}, 1 \mathrm{H}), 3.60(\mathrm{dd}, J=4.5,9.9 \mathrm{~Hz}, 1 \mathrm{H})$, $3.81(\mathrm{~s}, 3 \mathrm{H}), 3.87(\mathrm{dd}, J=2.0,5.8 \mathrm{~Hz}, 1 \mathrm{H}), 4.15(\mathrm{ddd}, J=2.1,4.5,6.7 \mathrm{~Hz}, 1 \mathrm{H}), 4.28(\mathrm{~d}, J=$ $11.6 \mathrm{~Hz}, 1 \mathrm{H}), 4.47$ (d, $J=11.6 \mathrm{~Hz}, 1 \mathrm{H}), 4.78(\mathrm{~d}, J=10.8 \mathrm{~Hz}, 1 \mathrm{H}), 4.83(\mathrm{~d}, J=10.8 \mathrm{~Hz}, 1 \mathrm{H})$, $6.82(\mathrm{~m}, 2 \mathrm{H}), 7.15-7.35(\mathrm{~m}, 5 \mathrm{H}) ;{ }^{13} \mathrm{C} \mathrm{NMR}\left(100 \mathrm{Mz}, \mathrm{CDCl}_{3}\right) \delta$ 10.5, 42.8, 55.7, 68.1, 71.4, 71.6, 82.6, 82.8, 82.9, 114.1, 128.8, 129.7, 130.3, 133.8, 137.3, 160.0 ; HRMS (FAB) $m / z .550 .0168$ ([M] $]^{+}$; calcd for $\mathrm{C}_{22} \mathrm{H}_{25} \mathrm{O}_{4}{ }^{35} \mathrm{Cl}_{2} \mathrm{I}: 550.0175$ ).

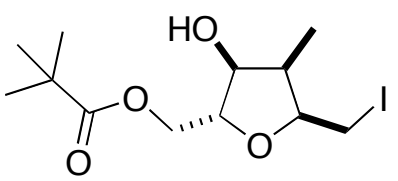

21 


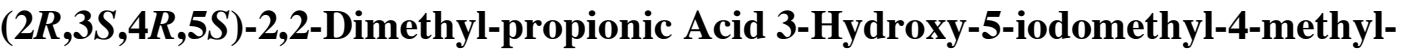

tetrahydrofuran-2-ylmethyl Ester (21). A solution of 20 (14.7 mg, $0.042 \mathrm{mmol}$ ) in dry $\mathrm{MeCN}$ (2 mL) was cooled to $-20{ }^{\circ} \mathrm{C}$ and a solution of iodine in dry $\mathrm{MeCN}$ (1.65 mL of a $0.038 \mathrm{M}$ soln, $0.063 \mathrm{mmol}$ ) was slowly added via syringe. The brown mixture was stirred for $3 \mathrm{~h}$ at $-20{ }^{\circ} \mathrm{C}$ then was allowed to warm to ambient temperature and was stirred until no starting material remained. After $5 \mathrm{~h}$, the mixture was diluted with saturated aqueous $\mathrm{Na}_{2} \mathrm{~S}_{2} \mathrm{O}_{3}(2 \mathrm{~mL})$ and $\mathrm{Et}_{2} \mathrm{O}$ and was stirred until it became colorless. The separated organic phase was dried over $\mathrm{MgSO}_{4}$. After concentration under reduced pressure, the residue was purified by flash chromatography (hexane-EtOAc, $4: 1)$ to give $12 \mathrm{mg}(80 \%)$ of $\mathbf{2 1}$ as a colorless oil: $[\alpha]_{\mathrm{D}}^{23}+15.4\left(\mathrm{c} 0.37, \mathrm{CHCl}_{3}\right)$; IR (neat) 3473, 2970, 2933, 2872, 1730, 1480, 1460, 1286, 1163, 1092, 1045, 961, 879, $802 \mathrm{~cm}^{-}$

${ }^{1} ;{ }^{1} \mathrm{H}$ NMR (400 MHz, $\left.\mathrm{CDCl}_{3}\right) \delta 1.04$ (d, $\left.J=7 \mathrm{~Hz}, 3 \mathrm{H}\right), 1.21$ (s, 9H), 1.92 (bs, 1H), 2.43-2.52 $(\mathrm{m}, 1 \mathrm{H}), 3.16(\mathrm{dd}, J=7,10 \mathrm{~Hz}, 1 \mathrm{H}), 3.32(\mathrm{dd}, J=8,10 \mathrm{~Hz}, 1 \mathrm{H}), 4.06(\mathrm{q}, J=5 \mathrm{~Hz}, 1 \mathrm{H}), 4.18$ $(\mathrm{dd}, J=3,4 \mathrm{~Hz}), 4.24(\mathrm{t}, J=6 \mathrm{~Hz}, 1 \mathrm{H}), 4.30(\mathrm{ddd}, J=6,7,8 \mathrm{~Hz}, 1 \mathrm{H}) ;{ }^{13} \mathrm{C} \mathrm{NMR}(100 \mathrm{MHz}$, $\left.\mathrm{CDCl}_{3}\right) \delta 5.4,7.3,27.6,39.3,40.8,64.8,75.3,82.0,82.3,179.0 ; \mathrm{MS}(\mathrm{CI}) \mathrm{m} / \mathrm{z} 357(\mathrm{M}+1)^{+}, 338$, 273, 254, 175, 109, 95; HRMS (CI) $m / z 357.0558\left([\mathrm{M}+1]^{+}\right.$; calc for $\left.\mathrm{C}_{12} \mathrm{H}_{22} \mathrm{O}_{4} \mathrm{I}: 357.0563\right)$.

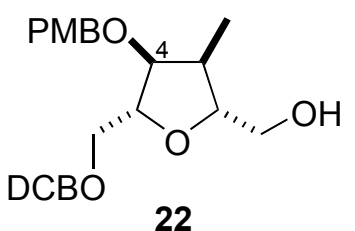

(2R,3S,4S,5R)-[5-(2,6-Dichlorobenzyloxymethyl)-4-(4-methoxyphenoxy-methyl)-3methyltetrahydrofuran-2-yl]methanol (22). To a solution of iodide 19 (9.40 g, $17 \mathrm{mmol})$ in DMF $(150 \mathrm{~mL})$ was added cesium trifluoroacetate $(20.9 \mathrm{~g}, 85 \mathrm{mmol})$ at room temperature. The mixture was stirred for $36 \mathrm{~h}$ at $90{ }^{\circ} \mathrm{C}$ and then cooled to room temperature. Diethylamine (10 
$\mathrm{mL}$ ) was added, and the resulting solution was stirred for $3 \mathrm{~h}$ at room temperature. The mixture was diluted with $\mathrm{Et}_{2} \mathrm{O}$ and washed with water and brine, and the organic layer was dried over $\mathrm{Na}_{2} \mathrm{SO}_{4}$, filtered, and concentrated. Flash chromatography (hexane-EtOAc, 2:1) of the residue afforded $6.80 \mathrm{~g}(92 \%)$ of 22: $[\alpha]_{\mathrm{D}}^{23}+2.4\left(\mathrm{c} 0.70, \mathrm{CHCl}_{3}\right)$; IR (neat) 3454, 2926, 2874, 1612, 1583, $1563,1513,1437,1247,1105,1035,822,780,768,783 \mathrm{~cm}^{-1} ;{ }^{1} \mathrm{H}$ NMR $\left(300 \mathrm{MHz}, \mathrm{CDCl}_{3}\right) \delta$ $1.02(\mathrm{~d}, J=7.0 \mathrm{~Hz}, 3 \mathrm{H}), 2.28(\mathrm{~m}, 1 \mathrm{H}), 2.31(\mathrm{brs}, 1 \mathrm{H}), 3.47(\mathrm{~m}, 1 \mathrm{H}), 3.54(\mathrm{dd}, J=3.6,9.8 \mathrm{~Hz}$, 1H), $3.62(\mathrm{dd}, J=4.9,9.8 \mathrm{~Hz}, 1 \mathrm{H}), 3.80(\mathrm{~s}, 3 \mathrm{H}), 3.81(\mathrm{~m}, 2 \mathrm{H}), 3.95(\mathrm{dd}, J=3.0,6.1 \mathrm{~Hz}, 1 \mathrm{H})$, $4.12(\mathrm{~m}, 1 \mathrm{H}), 4.39(\mathrm{~d}, J=11.5 \mathrm{~Hz}, 1 \mathrm{H}), 4.47(\mathrm{~d}, J=11.5 \mathrm{~Hz}, 1 \mathrm{H}), 4.80(\mathrm{~s}, 2 \mathrm{H}), 6.81(\mathrm{~d}, J=8.6$ $\mathrm{Hz}, 2 \mathrm{H}), 7.27(\mathrm{~m}, 3 \mathrm{H}), 7.34(\mathrm{~d}, J=8.0 \mathrm{~Hz}, 1 \mathrm{H}) ;{ }^{13} \mathrm{C} \mathrm{NMR}\left(100 \mathrm{Mz}, \mathrm{CDCl}_{3}\right) \delta 13.6,37.3,55.5$, 63.3, 67.8, 71.2, 71.6, 82.1, 82.4, 85.6, 114.0, 128.6, 129.5, 130.3, 130.6, 133.2, 137.1, 159.4; HRMS (CI) $m / z$ 440.1161 ([M] $]^{+}$; calcd for $\left.\mathrm{C}_{22} \mathrm{H}_{26} \mathrm{O}_{5}{ }^{35} \mathrm{Cl}_{2}: 440.1157\right)$.

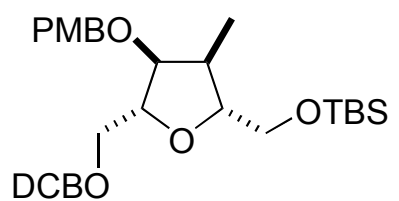

23

\section{$(2 R, 3 S, 4 S, 5 R)$-tert-Butyl-[5-(2,6-dichlorobenzyloxymethyl)-4-(4-methoxy-benzyloxy)-3-}

methyltetrahydrofuran-2-yl-methoxy]dimethylsilane (23). To a solution of alcohol 22 (6.8 g, $15 \mathrm{mmol})$ in DMF $(50 \mathrm{~mL})$ at $0{ }^{\circ} \mathrm{C}$ was added $\mathrm{TBSCl}(2.60 \mathrm{~g}, 17 \mathrm{mmol})$ and imidazole $(1.60 \mathrm{~g}$, $20 \mathrm{mmol}$ ). The mixture was stirred overnight at room temperature and DMF was removed under high vacuum. The residue was diluted with $\mathrm{Et}_{2} \mathrm{O}$ and water. After the phases were separated, the aqueous phase was extracted with $\mathrm{Et}_{2} \mathrm{O}(200 \mathrm{~mL}$ x 2). The combined organic layer was washed with brine and dried over $\mathrm{Na}_{2} \mathrm{SO}_{4}$, filtered and concentrated. Flash chromatography (hexaneEtOAc, 6:1) of the residue afforded $8.20 \mathrm{~g}(95 \%)$ of 23: $[\alpha]_{\mathrm{D}}^{23}-21.4\left(\mathrm{c} 1.51, \mathrm{CHCl}_{3}\right)$; IR (neat) 
$2954,2928,2857,1614,1583,1563,1513,1461,1248,1109,1004,837,778,768 \mathrm{~cm}^{-1} ;{ }^{1} \mathrm{H}$ NMR (300 MHz, CDCl $) \delta 0.05(\mathrm{~s}, 6 \mathrm{H}), 0.89(\mathrm{~s}, 9 \mathrm{H}), 1.02(\mathrm{~d}, J=7.0 \mathrm{~Hz}, 3 \mathrm{H}), 2.18(\mathrm{~m}, 1 \mathrm{H})$, $3.48(\mathrm{~m}, 1 \mathrm{H}), 3.60(\mathrm{~m}, 2 \mathrm{H}), 3.72(\mathrm{~m}, 2 \mathrm{H}), 3.81(\mathrm{~s}, 3 \mathrm{H}), 3.81(\mathrm{~m}, 1 \mathrm{H}), 4.12(\mathrm{~m}, 1 \mathrm{H}), 4.37(\mathrm{~d}, J=$ $11.5 \mathrm{~Hz}, 1 \mathrm{H}), 4.49(\mathrm{~d}, J=11.5 \mathrm{~Hz}, 1 \mathrm{H}), 4.77(\mathrm{~d}, J=10.8 \mathrm{~Hz}, 1 \mathrm{H}), 4.52(\mathrm{~d}, J=10.8 \mathrm{~Hz}, 1 \mathrm{H})$, $6.81(\mathrm{~d}, J=8.6 \mathrm{~Hz}, 2 \mathrm{H}), 7.19(\mathrm{~m}, 3 \mathrm{H}), 7.34(\mathrm{~d}, J=8.0 \mathrm{~Hz}, 1 \mathrm{H}) ;{ }^{13} \mathrm{C} \mathrm{NMR}\left(100 \mathrm{Mz}, \mathrm{CDCl}_{3}\right) \delta-$ $5.1,-5.2,10.8,26.2,37.8,55.4,64.3,67.9,71.1,81.9,82.6,85.1,113.8,128.6,129.5,130.0$, 130.8, 133.7, 137.1, 159.2; HRMS (CI) $\mathrm{m} / \mathrm{z} 553.1958\left([\mathrm{M}-\mathrm{H}]^{+}\right.$; calcd for $\mathrm{C}_{28} \mathrm{H}_{39} \mathrm{O}_{5}{ }^{35} \mathrm{Cl}_{2} \mathrm{Si}$ : 553.1944).

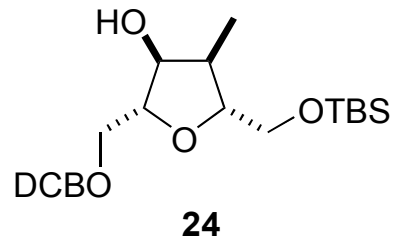

$(2 R, 3 R, 4 S, 5 R)-5$-(tert-Butyldimethylsilanyloxymethyl)-2-(2,6-dichloro-benzyloxymethyl)-

4-methyltetrahydrofuran-3-ol (24). To a solution of ether $23(0.67 \mathrm{~g}, 1.20 \mathrm{mmol})$ in a mixture of $\mathrm{CH}_{2} \mathrm{Cl}_{2}(10 \mathrm{~mL})$ and buffer $(\mathrm{pH}=7,0.5 \mathrm{~mL})$ at $0{ }^{\circ} \mathrm{C}$ was added 2,3-dichloro-4,5-dicyano-1,4benzoquinone $(0.32 \mathrm{~g}, 1.40 \mathrm{mmol})$, and the mixture was stirred for $3 \mathrm{~h}$ at room temperature. The reaction was quenched by addition of saturated aqueous $\mathrm{NaHCO}_{3}$, and the mixture was diluted with $\mathrm{CH}_{2} \mathrm{Cl}_{2}$. The phases were separated and the aqueous phase was extracted with $\mathrm{CH}_{2} \mathrm{Cl}_{2}$. The combined organic phase was washed with brine, dried over $\mathrm{Na}_{2} \mathrm{SO}_{4}$, and concentrated under vacuum. Flash chromatography (hexane-EtOAc, 4:1) of the residue afforded $0.48 \mathrm{~g}(94 \%)$ of $\mathbf{2 4}$ : $[\alpha]_{\mathrm{D}}^{23}-20.3$ (c 2.15, $\mathrm{CHCl}_{3}$ ); IR (neat) 3439, 2954, 2928, 2883, 2857, 1582, 1564, 1471, 1462, 1437, 1252, 1197, 1108, 1003, 837, $777 \mathrm{~cm}^{-1} ;{ }^{1} \mathrm{H}$ NMR $\left(300 \mathrm{MHz}, \mathrm{CDCl}_{3}\right) \delta 0.04(\mathrm{~s}, 6 \mathrm{H}), 0.9(\mathrm{~s}$, 9H), $1.02(\mathrm{~d}, J=7.1 \mathrm{~Hz}, 3 \mathrm{H}), 1.87(\mathrm{~d}, J=3.6 \mathrm{~Hz}, 1 \mathrm{H}), 2.12(\mathrm{~m}, 1 \mathrm{H}), 3.43(\mathrm{dd}, J=7.4,9.8 \mathrm{~Hz}$, 
1H), $3.65-3.70(\mathrm{~m}, 4 \mathrm{H}), 4.00(\mathrm{~m}, 1 \mathrm{H}), 4.12(\mathrm{~m}, 1 \mathrm{H}), 4.75(\mathrm{~d}, J=10.8 \mathrm{~Hz}, 2 \mathrm{H}), 4.81(\mathrm{~d}, J=$ $10.9 \mathrm{~Hz}, 1 \mathrm{H}), 7.17(\mathrm{dd}, J=7.4,8.9 \mathrm{~Hz}, 1 \mathrm{H}), 7.31(\mathrm{~d}, J=8.1 \mathrm{~Hz}, 2 \mathrm{H}) ;{ }^{13} \mathrm{C} \mathrm{NMR}(100 \mathrm{Mz}$, $\left.\mathrm{CDCl}_{3}\right) \delta-5.0,10.7,18.8,26.4,38.8,64.7,68.1,72.0,76.9,84.5,85.1,128.8,130.3,133.7$ 137.3; HRMS (CI) $m / z 434.1444$ ([M] $]^{+}$; calcd for $\mathrm{C}_{20} \mathrm{H}_{32} \mathrm{Cl}_{2} \mathrm{O}_{4} \mathrm{Si}$ : 434.1447).

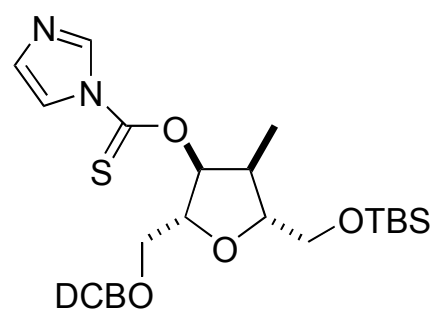

\section{(2R,3S,4S,5R)-tert-Butyl-[5-(2,6-dichlorobenzyloxymethyl)-4-(1H-imidazole-1-}

carbothioate)-3-methyltetrahydrofuran-2-yl-methoxy]dimethylsilane. To a solution of alcohol $24(0.42 \mathrm{~g}, 0.96 \mathrm{mmol})$ in dry toluene $(10 \mathrm{~mL})$ at room temperature was added thiocarbonyldiimidazole $(0.51 \mathrm{~g}, 2.9 \mathrm{mmol})$ under argon. The mixture was heated at $100{ }^{\circ} \mathrm{C}$ for $3 \mathrm{~h}$. After the mixture was cooled to room temperature, the solvent was removed under vacuum. Flash chromatography (hexane-EtOAc, $1: 1)$ of the residue gave $0.48 \mathrm{~g}(92 \%)$ of a thioate: $[\alpha]_{D}^{23}-$ 24.2 (c $0.73, \mathrm{CHCl}_{3}$ ); IR (neat) 3128, 2953, 2928, 2882, 2856, 1582, 1564, 1471, 1462, 1437, 1390, 1337, 1285, 1230, 1101, 1038, 838, $778 \mathrm{~cm}^{-1} ;{ }^{1} \mathrm{H}$ NMR (300 MHz, $\left.\mathrm{CDCl}_{3}\right) \delta 0.08$ (s, 6H), $0.90(\mathrm{~s}, 9 \mathrm{H}), 1.08(\mathrm{~d}, J=7.0 \mathrm{~Hz}, 1 \mathrm{H}), 2.41(\mathrm{~m}, 1 \mathrm{H}), 3.68(\mathrm{dd}, J=4.2,10.2 \mathrm{~Hz}, 1 \mathrm{H}), 3.73-3.83$ $(\mathrm{m}, 4 \mathrm{H}), 4.25(\mathrm{td}, J=1.6,4.0 \mathrm{~Hz}, 1 \mathrm{H}), 4.82(\mathrm{~s}, 2 \mathrm{H}), 5.84(\mathrm{dd}, J=1.6,4.5 \mathrm{~Hz}, 1 \mathrm{H}), 7.03(\mathrm{~s}, 1 \mathrm{H})$, $7.19(\mathrm{dd}, J=7.2,8.8 \mathrm{~Hz}, 1 \mathrm{H}), 7.32(\mathrm{dd}, J=1.0,7.6 \mathrm{~Hz}, 2 \mathrm{H}), 7.59(\mathrm{~s}, 1 \mathrm{H}), 8.32(\mathrm{~s}, 1 \mathrm{H}) ;{ }^{13} \mathrm{C}$ NMR $\left(100 \mathrm{Mz}, \mathrm{CDCl}_{3}\right) \delta-5.0,10.9,18.8,26.4,39.6,64.8,68.4,71.3,83.1,85.8,88.7,118.2$, $128.8,130.4,131.3,133.3,137.3,183.8 ;$ HRMS (CI) $m / z \quad 545.1460\left([\mathrm{M}]^{+}\right.$; calcd for $\left.\mathrm{C}_{24} \mathrm{H}_{35} \mathrm{O}_{4} \mathrm{~N}_{2} \mathrm{Si}^{35} \mathrm{Cl}_{2} \mathrm{~S}: 545.1464\right)$. 


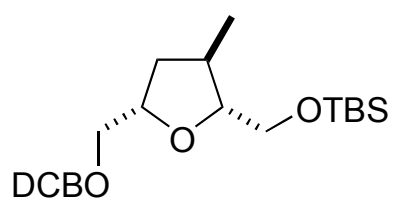

25

\section{$(2 R, 3 R, 5 S)$-tert-Butyl-[5-(2,6-dichlorobenzyloxymethyl)-3-methyltetrahydrofuran-2-yl-}

methoxy]dimethylsilane (25). To a solution of $n$ - $\mathrm{Bu}_{3} \mathrm{SnH}(0.21 \mathrm{~mL}, 0.79 \mathrm{mmol})$ and a catalytic amount of AIBN in dry, deoxygenated toluene $(30 \mathrm{~mL})$ at $100{ }^{\circ} \mathrm{C}$ was slowly added a solution of the thioate prepared above $(0.22 \mathrm{~g}, 0.39 \mathrm{mmol})$ in toluene $(10 \mathrm{~mL})$ via syringe during $30 \mathrm{~min}$. The mixture was stirred for $5 \mathrm{~min}$ at $100{ }^{\circ} \mathrm{C}$, then was cooled to room temperature and concentrated under vacuum. Flash chromatography (hexane-EtOAc, 10:1) of the residue afforded $0.16 \mathrm{~g}(96 \%)$ of 25 as a colorless oil: $[\alpha]_{\mathrm{D}}^{23}-10.6\left(\mathrm{c} 0.32, \mathrm{CHCl}_{3}\right)$; IR (neat) 2955, 2928, $2856,1564,1471,1461,1437,1254,1103,836,776 \mathrm{~cm}^{-1}$; $1 \mathrm{H}$ NMR $\left(300 \mathrm{MHz}, \mathrm{CDCl}_{3}\right) \delta 0.05$ (s, 6H), $0.89(\mathrm{~s}, 9 \mathrm{H}), 1.02(\mathrm{~d}, J=6.7 \mathrm{~Hz}, 3 \mathrm{H}), 1.60(\mathrm{~m}, 1 \mathrm{H}), 1.95(\mathrm{~m}, 1 \mathrm{H}), 2.08(\mathrm{~m}, 1 \mathrm{H}), 3.40-$ $3.65(\mathrm{~m}, 5 \mathrm{H}), 4.18(\mathrm{~m}, 1 \mathrm{H}), 4.79(\mathrm{~d}, J=11.8 \mathrm{~Hz}, 1 \mathrm{H}), 4.82(\mathrm{~d}, J=11.8 \mathrm{~Hz}, 1 \mathrm{H}), 7.18(\mathrm{dd}, J=$ 7.4, 8.6 Hz, $1 \mathrm{H}), 7.31(\mathrm{~d}, J=7.9 \mathrm{~Hz}, 2 \mathrm{H}) ;{ }^{13} \mathrm{C} \mathrm{NMR}\left(100 \mathrm{Mz}, \mathrm{CDCl}_{3}\right) \delta-4.9,18.4,18.8,26.4$, 35.0, 37.3, 65.5, 68.1, 74.0, 77.4, 87.2, 128.7, 130.2, 133.9, 137.3; HRMS (CI) $\mathrm{m} / z 417.1422$ $\left([\mathrm{M}]^{+}\right.$; calcd for $\mathrm{C}_{20} \mathrm{H}_{31} \mathrm{O}_{3}{ }^{35} \mathrm{Cl}_{2} \mathrm{Si}: 417.1420$ ).

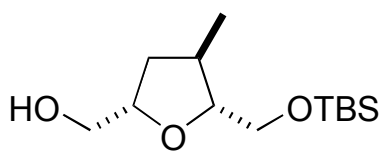

26

\section{$(2 S, 3 R, 5 R)$-[5-(tert-Butyldimethylsilanyloxymethyl)-4-methyltetrahydrofuran-2-}

yl]methanol (26). To a solution of lithium $(68.0 \mathrm{mg}, 6.18 \mathrm{mmol})$ in liquid $\mathrm{NH}_{3}(3 \mathrm{~mL})$ at $-78{ }^{\circ} \mathrm{C}$ was added a solution of ether $\mathbf{2 5}(408.0 \mathrm{mg}, 0.98 \mathrm{mmol})$ in THF ( $3 \mathrm{~mL})$. The mixture was stirred 
at $-78{ }^{\circ} \mathrm{C}$ for $30 \mathrm{~min}$ and the reaction was quenched with saturated $\mathrm{NH}_{4} \mathrm{Cl}$. The resulting mixture was stirred at room temperature for $3 \mathrm{~h}$ and diluted with EtOAc. The organic layer was separated, washed with water and brine, dried over $\mathrm{Na}_{2} \mathrm{SO}_{4}$, and concentrated under vacuum. Flash chromatography (hexane-EtOAc, 2:1) of the residue afforded $183.0 \mathrm{mg}(72 \%)$ of $\mathbf{2 6}$ as a colorless oil: $[\alpha]_{\mathrm{D}}^{23}-2.9\left(\mathrm{c} 1.0, \mathrm{CHCl}_{3}\right)$; IR (neat) 3463, 2956, 2929, 2857, 1461, 1255, 1103, 837, $777 \mathrm{~cm}^{-1} ;{ }^{1} \mathrm{H}$ NMR (400 MHz, $\left.\mathrm{CDCl}_{3}\right) \delta 0.05(\mathrm{~s}, 6 \mathrm{H}), 0.91(\mathrm{~s}, 9 \mathrm{H}), 1.05(\mathrm{~d}, J=6.8 \mathrm{~Hz}, 3 \mathrm{H}), 1.69$ (ddd, $J=8.7,8.8,12.3 \mathrm{~Hz}, 1 \mathrm{H}), 2.09$ (ddd, $J=4.0,8.0,12.1 \mathrm{~Hz}, 1 \mathrm{H}), 2.35(\mathrm{~m}, 1 \mathrm{H}), 2.83$ (brs,

$1 \mathrm{H}), 3.52(\mathrm{ddd}, J=3.0,3.0,8.0 \mathrm{~Hz}, 1 \mathrm{H}), 3.65(\mathrm{dd}, J=2.7,11.0 \mathrm{~Hz}, 1 \mathrm{H}), 3.75(\mathrm{dd}, J=2.8,11.5$ $\mathrm{Hz}, 1 \mathrm{H}), 3.85(\mathrm{dd}, J=3.2,11.0 \mathrm{~Hz}, 1 \mathrm{H}), 4.15(\mathrm{~m}, 1 \mathrm{H}) ;{ }^{13} \mathrm{C} \mathrm{NMR}\left(100 \mathrm{Mz}, \mathrm{CDCl}_{3}\right) \delta-5.3,-5.2$, 17.8, 18.7, 16.2, 34.3, 37.0, 65.9, 66.4, 78.8, 87.0; HRMS (CI) $\mathrm{m} / z 261.1889\left([\mathrm{M}+\mathrm{H}]^{+}\right.$; calcd. for $\left.\mathrm{C}_{13} \mathrm{H}_{29} \mathrm{O}_{3} \mathrm{Si}: 261.1886\right)$.

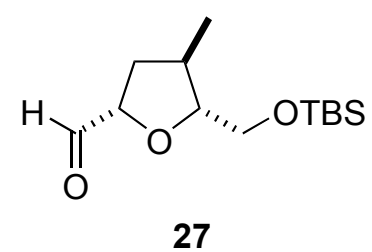

\section{$(2 S, 3 R, 5 R)$-[5-(tert-Butyldimethylsilanyloxymethyl)-4-methyltetrahydrofuran-2-}

carbaldehyde (27). To a solution of oxalyl chloride (10 $\mu \mathrm{L}, 0.12 \mathrm{mmol})$ in $\mathrm{CH}_{2} \mathrm{Cl}_{2}(1 \mathrm{~mL})$ at $78{ }^{\circ} \mathrm{C}$ was added DMSO $(13 \mu \mathrm{L}, 0.16 \mathrm{mmol})$. The mixture was stirred for $5 \mathrm{~min}$, and a solution of alcohol 26 (21.0 mg, $0.081 \mathrm{mmol})$ in $\mathrm{CH}_{2} \mathrm{Cl}_{2}(0.5 \mathrm{~mL})$ was added. The mixture was stirred for $15 \mathrm{~min}$ at $-78{ }^{\circ} \mathrm{C}, \mathrm{Et}_{3} \mathrm{~N}(22 \mu \mathrm{L}, 0.16 \mathrm{mmol})$ was added, and the resulting mixture was allowed to warm to room temperature. The reaction was quenched by addition of saturated aqueous $\mathrm{NaHCO}_{3}$, and the mixture was diluted with $\mathrm{CH}_{2} \mathrm{Cl}_{2}$. After the phases were separated, the aqueous phase was extracted with $\mathrm{CH}_{2} \mathrm{Cl}_{2}(2 \mathrm{x})$. The combined organic layer was washed with brine, 
dried over $\mathrm{Na}_{2} \mathrm{SO}_{4}$, and concentrated under vacuum. Flash chromatography (hexane-EtOAc, 4:1)

of the residue gave $19.0 \mathrm{mg}(91 \%)$ of 27 : $[\alpha]_{\mathrm{D}}^{23}-46.4$ (c 0.85, $\mathrm{CHCl}_{3}$ ); IR (neat) 2956, 2928, 2857, 1735, 1462, 1255, 1101, 837, $777 \mathrm{~cm}^{-1} ;{ }^{1} \mathrm{H}$ NMR (400 MHz, $\left.\mathrm{CDCl}_{3}\right) \delta 0.10(\mathrm{~s}, 6 \mathrm{H}), 0.92$ (s, 9H), $1.10(\mathrm{~d}, J=6.6 \mathrm{~Hz}, 3 \mathrm{H}), 1.85(\mathrm{~m}, 1 \mathrm{H}), 2.13(\mathrm{~m}, 1 \mathrm{H}), 2.30(\mathrm{ddd}, J=4.2,7.4,11.9 \mathrm{~Hz}$, 1H), $3.70(\mathrm{~m}, 2 \mathrm{H}), 3.80(\mathrm{~m}, 1 \mathrm{H}), 4.32(\mathrm{ddd}, J=1.2,4.0,8.7 \mathrm{~Hz}, 1 \mathrm{H}), 9.74(\mathrm{~d}, J=1.4 \mathrm{~Hz}, 1 \mathrm{H})$; ${ }^{13} \mathrm{C}$ NMR $\left(100 \mathrm{Mz}, \mathrm{CDCl}_{3}\right) \delta-5.0(-5.0), 17.8,18.8,26.3,35.0,37.0,64.7,82.9,88.2,209.5$; HRMS (CI) $\mathrm{m} / z 259.1718\left([\mathrm{M}+\mathrm{H}]^{+}\right.$; calcd for $\left.\mathrm{C}_{13} \mathrm{H}_{27} \mathrm{O}_{3} \mathrm{Si}: 259.1729\right)$.

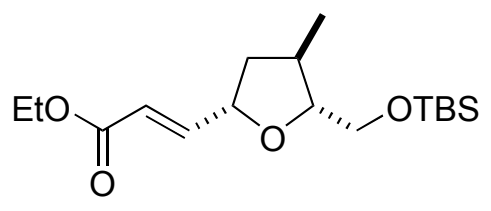

29

\section{$\left(2^{\prime} S, 3^{\prime} R, 5^{\prime} R\right)-3-\left[5^{\prime}\right.$-(tert-Butyldimethylsilanyloxymethyl)-4'-methyltetrahydrofuran-2'-yl]-}

2-E-acrylic Acid Ethyl Ester (29). To a solution of triethyl phosphonoacetate (28, $29 \mu \mathrm{L}, 0.15$ mmol) in THF $(1 \mathrm{~mL})$ at $0{ }^{\circ} \mathrm{C}$ was added $n$-BuLi $(56 \mu \mathrm{L}$ of $1.95 \mathrm{M}$ in hexane, $0.11 \mathrm{~mL})$. The mixture was stirred at $0{ }^{\circ} \mathrm{C}$ for $10 \mathrm{~min}$ and at room temperature for $10 \mathrm{~min}$. The mixture was cooled to $0{ }^{\circ} \mathrm{C}$ and a solution of aldehyde $27(19.0 \mathrm{mg}, 0.073 \mathrm{ml})$ in THF $(0.5 \mathrm{~mL})$ was added. The resulting mixture was stirred at room temperature for $1 \mathrm{~h}$ and the reaction was quenched by addition of saturated $\mathrm{NH}_{4} \mathrm{Cl}$. The mixture was diluted with EtOAc and water. The phases were separated and the aqueous phase was extracted with EtOAc $(2 \mathrm{x})$. The combined organic layer was washed with brine, dried over $\mathrm{Na}_{2} \mathrm{SO}_{4}$, and concentrated under vacuum. Flash chromatography (hexane-EtOAc, 4:1) of the residue gave $19.7 \mathrm{~g}(82 \%)$ of 29 : $[\alpha]_{D}^{23}-1.5$ (c 0.60 , $\mathrm{CHCl}_{3}$ ); IR (neat) 2957, 2929, 2857, 1723, 1660, 1462, 1367, 1301, 1258, 1171, 1135, 1101, 1044, 982, 837, $777 \mathrm{~cm}^{-1}$; 1H NMR (400 MHz, $\left.\mathrm{CDCl}_{3}\right) \delta 0.11(\mathrm{~s}, 3 \mathrm{H}), 0.12(\mathrm{~s}, 3 \mathrm{H}), 0.94(\mathrm{~s}, 9 \mathrm{H})$, 
$1.09(\mathrm{~d}, J=7.0 \mathrm{~Hz}, 3 \mathrm{H}), 1.31(\mathrm{t}, J=7.1 \mathrm{~Hz}, 3 \mathrm{H}), 1.85(\mathrm{~m}, 1 \mathrm{H}), 1.95(\mathrm{~m}, 1 \mathrm{H}), 2.20(\mathrm{~m}, 1 \mathrm{H}), 3.60$ (m, 1H), $3.72(\mathrm{~d}, \mathrm{~J}=4.4 \mathrm{~Hz}, 2 \mathrm{H}), 4.22(\mathrm{q}, J=7.1 \mathrm{~Hz}, 2 \mathrm{H}), 4.64(\mathrm{~m}, 1 \mathrm{H}), 6.10(\mathrm{dd}, J=1.4,15.5$ $\mathrm{Hz}, 1 \mathrm{H}), 6.94(\mathrm{dd}, J=5.0,15.6 \mathrm{~Hz}, 1 \mathrm{H}) ;{ }^{13} \mathrm{C} \mathrm{NMR}\left(100 \mathrm{Mz}, \mathrm{CDCl}_{3}\right) \delta-5.0,-4.9,14.7,17.8$, 26.4, 34.7, 40.2, 60.7, 64.9, 77.0, 87.7, 120.7, 149.5, 172.5; HRMS (CI) $\mathrm{m} / z$ 329.2134([M+H $]^{+}$; calcd for $\left.\mathrm{C}_{17} \mathrm{H}_{33} \mathrm{O}_{4} \mathrm{Si}: 329.2148\right)$.

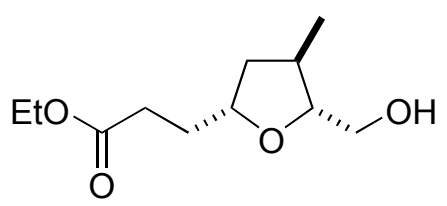

31

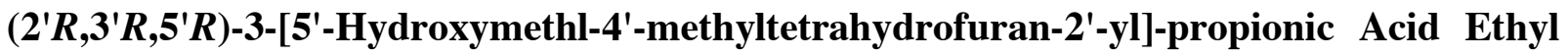

Ester (31). From 29. To a solution of ester $29(22 \mathrm{mg}, 0.067 \mathrm{mmol})$ in EtOH $(0.8 \mathrm{~mL})$ was added 5\% $\mathrm{Pd} / \mathrm{C}(5 \mathrm{mg})$ and the mixture was stirred under a $\mathrm{H}_{2}$ atmosphere for $12 \mathrm{~h}$ at room temperature. After filtration, the filtrate was concentrated.

To a solution of the residue obtained above in THF $(0.9 \mathrm{~mL})$ at $0{ }^{\circ} \mathrm{C}$ was added TBAF $(0.1 \mathrm{~mL}$ of $1 \mathrm{M}$ solution in THF, $0.1 \mathrm{mmol}$ ). The mixture was stirred at room temperature for $3 \mathrm{~h}$ and the reaction was quenched by addition of saturated $\mathrm{NH}_{4} \mathrm{Cl}$ solution and the mixture was diluted with EtOAc and water. After the phases had separated, the aqueous phase was extracted with EtOAc $(2 \mathrm{x})$. The combined organic layer was washed with brine, dried over $\mathrm{Na}_{2} \mathrm{SO}_{4}$, and concentrated under vacuum. Flash chromatography (hexane-EtOAc, 3:1) of the residue gave $12 \mathrm{mg}(83 \%)$ of 31: $[\alpha]_{\mathrm{D}}^{23}-10.0\left(\mathrm{c} 0.69, \mathrm{CHCl}_{3}\right)$; IR (neat) $3437,2956,2924,2872,1734,1457,1374,1259$, 1175, 1109, $1038 \mathrm{~cm}^{-1}$; 1H NMR (400 MHz, $\left.\mathrm{CDCl}_{3}\right) \delta 1.05(\mathrm{~d}, J=6.7 \mathrm{~Hz}, 3 \mathrm{H}), 1.30(\mathrm{t}, J=7.1$ $\mathrm{Hz}, 3 \mathrm{H}), 1.70-1.92(\mathrm{~m}, 4 \mathrm{H}), 2.21(\mathrm{~m}, 1 \mathrm{H}), 2.35-2.45(\mathrm{~m}, 3 \mathrm{H}), 3.52(\mathrm{~m}, 2 \mathrm{H}), 3.76(\mathrm{~m}, 1 \mathrm{H})$, $4.05(\mathrm{~m}, 1 \mathrm{H}), 4.16(\mathrm{q}, J=7.1 \mathrm{~Hz}, 2 \mathrm{H}) ;{ }^{13} \mathrm{C} \mathrm{NMR}\left(100 \mathrm{Mz}, \mathrm{CDCl}_{3}\right) \delta 14.6,17.7,31.7,31.8,33.5$, 
40.2, 60.9, 63.4, 77.0, 87.3, 174.7; HRMS (CI) $\mathrm{m} / \mathrm{z} 217.1430\left([\mathrm{M}+\mathrm{H}]^{+}\right.$; calcd for $\mathrm{C}_{11} \mathrm{H}_{20} \mathrm{O}_{4}$ :

217.1440).

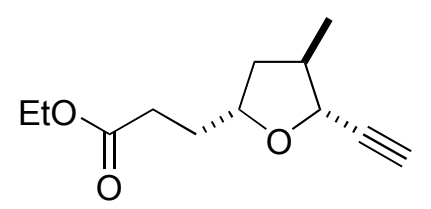

32

$\left(2^{\prime} R, 3^{\prime} R, 5^{\prime} R\right)-3-\left(5^{\prime}-\right.$ Ethynyl-4'-methyltetrahydrofuran-2'-yl)propionic Acid Ethyl Ester (32). To a solution of oxalyl chloride $(7.0 \mu \mathrm{L}, 0.074 \mathrm{mmol})$ in $\mathrm{CH}_{2} \mathrm{Cl}_{2}(0.3 \mathrm{~mL})$ at $-78{ }^{\circ} \mathrm{C}$ was added DMSO $(11.0 \mu \mathrm{L}, 0.15 \mathrm{mmol})$. The mixture was stirred for $20 \mathrm{~min}$, and a solution of alcohol $31(8.0 \mathrm{mg}, 0.037 \mathrm{mmol})$ in $\mathrm{CH}_{2} \mathrm{Cl}_{2}(0.2 \mathrm{~mL})$ was added. After the mixture had stirred for $30 \mathrm{~min}$ at $-78{ }^{\circ} \mathrm{C}, \mathrm{Et}_{3} \mathrm{~N}(20 \mu \mathrm{L}, 0.15 \mathrm{mmol})$ was added, and the resulting mixture was stirred at $-78{ }^{\circ} \mathrm{C}$ for $30 \mathrm{~min}$ and at $0{ }^{\circ} \mathrm{C}$ for $10 \mathrm{~min}$. The reaction was quenched by addition of saturated aqueous $\mathrm{NaHCO}_{3}$, and the mixture was diluted with $\mathrm{CH}_{2} \mathrm{Cl}_{2}$. After the phases had separated, the aqueous phase was extracted with $\mathrm{CH}_{2} \mathrm{Cl}_{2}(2 \mathrm{x})$. The combined organic layer was washed with brine, dried over $\mathrm{Na}_{2} \mathrm{SO}_{4}$, and concentrated to afford crude aldehyde.

To a solution of potassium tert-butoxide $(0.5 \mathrm{M}$ in THF, $0.19 \mathrm{~mL}, 0.093 \mathrm{mmol})$ in THF (0.3 $\mathrm{mL}$ ) at $-78{ }^{\circ} \mathrm{C}$ was added a solution of diethyl (diazomethyl)phosphonate $(\mathbf{3 3}, 20 \mathrm{mg}, 0.11$ mmol) in THF $(0.2 \mathrm{~mL})$. The mixture was stirred for $5 \mathrm{~min}$, and a solution of the aldehyde obtained above in THF $(0.3 \mathrm{~mL})$ was added slowly. The mixture was allowed to warm to room temperature, after which the reaction was quenched by addition of water $(2 \mathrm{~mL})$. The solvent was removed under vacuum and the residue was partitioned between EtOAc and water. The phases were separated, the aqueous phase was extracted with EtOAc $(2 \mathrm{x})$, and the combined organic layer was washed with brine, dried over $\mathrm{Na}_{2} \mathrm{SO}_{4}$, and concentrated under vacuum. Flash 
chromatography (hexane-EtOAc, 5:1) of the residue afforded $4.1 \mathrm{mg}(51 \%)$ of alkyne 32: $[\alpha]_{D}^{23}$ +9.7 (c 0.75, $\left.\mathrm{CHCl}_{3}\right)$; IR (neat) 3292, 2961, 2927, 2873, 2856, 2119, 1733, 1456, 1373, 1303, 1260, 1164, 1104, 1062, 932, $803 \mathrm{~cm}^{-1} ;{ }^{1} \mathrm{H}$ NMR $\left(400 \mathrm{MHz}, \mathrm{CDCl}_{3}\right) \delta 1.13(\mathrm{~d}, \mathrm{~J}=6.7 \mathrm{~Hz}, 3 \mathrm{H})$, $1.29(\mathrm{t}, J=7.1 \mathrm{~Hz}, 3 \mathrm{H}), 1.73(\mathrm{~m}, 1 \mathrm{H}), 1.89-1.96(\mathrm{~m}, 3 \mathrm{H}), 2.34-2.55(\mathrm{~m}, 3 \mathrm{H}), 2.49(\mathrm{~d}, J=2.0$ $\mathrm{Hz}, 1 \mathrm{H}), 4.08-4.10(\mathrm{~m}, 2 \mathrm{H}), 4.16(\mathrm{q}, J=7.1 \mathrm{~Hz}, 2 \mathrm{H}) ;{ }^{13} \mathrm{C} \mathrm{NMR}\left(100 \mathrm{Mz}, \mathrm{CDCl}_{3}\right) \delta$ 14.6, 17.4, $31.3,31.8,39.3,41.5,60.8,73.4,75.2,78.4,83.6,173.9$; HRMS (CI) $m / z 211.1333\left([\mathrm{M}+\mathrm{H}]^{+}\right.$; calcd for $\mathrm{C}_{12} \mathrm{H}_{19} \mathrm{O}_{3}:$ 211.1334).

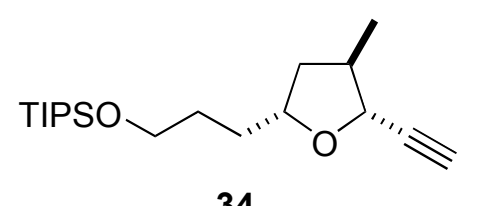

34

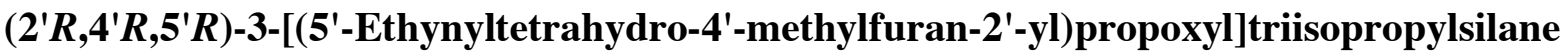

(34). To a solution of ethyl ester $32(21.5 \mathrm{mg}, 0.10 \mathrm{mmol})$ in $\mathrm{Et}_{2} \mathrm{O}(1 \mathrm{ml})$ at $0{ }^{\circ} \mathrm{C}$ was added $\mathrm{LiAlH}_{4}(10 \mathrm{mg}, 0.26 \mathrm{mmol})$. After stirring for $1 \mathrm{~h}$, the reaction was quenched by sequential addition of water $(10 \mu \mathrm{L}), \mathrm{NaOH}(15 \%, 10 \mu \mathrm{L})$, and water $(30 \mu \mathrm{L})$. The mixture was dried over $\mathrm{Na}_{2} \mathrm{SO}_{4}$, filtered, and concentrated.

To a solution of the residue obtained above in $\mathrm{CH}_{2} \mathrm{Cl}_{2}(1 \mathrm{~mL})$ at $0{ }^{\circ} \mathrm{C}$ was added imidazole (20 $\mathrm{mg}, 0.29 \mathrm{mmol})$, DMAP $(2 \mathrm{mg})$, and TIPSCl $(0.05 \mathrm{~mL}, 0.23 \mathrm{mmol})$. The mixture was stirred overnight at room temperature, after which a saturated solution of $\mathrm{NH}_{4} \mathrm{Cl}$ was added and the mixture was diluted with EtOAc. The phases were separated, the aqueous phase was extracted with EtOAc (2 x), and the combined organic layer was washed with brine, dried over $\mathrm{Na}_{2} \mathrm{SO}_{4}$, and concentrated under vacuum. Flash chromatography (hexane-EtOAc, 15:1) of the residue yielded $37.2 \mathrm{mg}(86 \%)$ of 34: $[\alpha]_{\mathrm{D}}^{23}-7.3\left(\mathrm{c} 1.04, \mathrm{CHCl}_{3}\right)$; IR (neat) 3313, 2942, 2891, 2866, 
2120, 1463, 1382, 1102, 1064, 999, 919, 882, 792, $727 \mathrm{~cm}^{-1} ;{ }^{1} \mathrm{H}$ NMR (400 MHz, $\left.\mathrm{CDCl}_{3}\right) \delta 1.04$ $(\mathrm{m}, 3 \mathrm{H}), 1.05(\mathrm{~s}, 18 \mathrm{H}), 1.10(\mathrm{~d}, J=6.7 \mathrm{~Hz}, 3 \mathrm{H}), 1.60-1.75(\mathrm{~m}, 5 \mathrm{H}), 1.88(\mathrm{~m}, 1 \mathrm{H}), 2.35(\mathrm{~m}$, $1 \mathrm{H}), 2.43(\mathrm{~d}, J=2.0 \mathrm{~Hz}, 1 \mathrm{H}), 3.69(\mathrm{~m}, 2 \mathrm{H}), 3.99(\mathrm{dd}, J=1.9,7.0 \mathrm{~Hz}, 2 \mathrm{H}) ;{ }^{13} \mathrm{C}$ NMR $(100 \mathrm{Mz}$, $\left.\mathrm{CDCl}_{3}\right) \delta 12.4,17.5,18.4,29.9,33.1,39.5,41.5,63.3,73.2,75.1,79.5,83.8$; HRMS (FAB) $\mathrm{m} / \mathrm{z}$ $325.2541\left([\mathrm{M}+\mathrm{H}]^{+}\right.$; calcd for $\left.\mathrm{C}_{19} \mathrm{H}_{37} \mathrm{O}_{2} \mathrm{Si}: 325.2563\right)$.

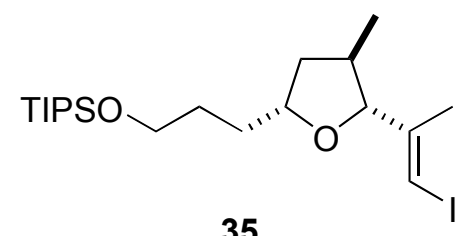

\section{$(2 R, 4 R, 5 R)-[3-(5-((E)-1-I o d o p r o p-1-e n-2-y l)-4-m e t h y l f u r a n-2-$}

yl)propoxy]triisopropylsilane (35). To a suspension of $\mathrm{CuCN}$ (54 mg, $0.60 \mathrm{mmol}$ ) in THF (2 $\mathrm{mL})$ at $-78{ }^{\circ} \mathrm{C}$ was added $n$-BuLi $(0.48 \mathrm{~mL}$ of $2.50 \mathrm{M}$ in hexane, $1.20 \mathrm{mmol})$. After stirring for $20 \mathrm{~min}$ at $-65{ }^{\circ} \mathrm{C}$, the mixture was recooled to $-78{ }^{\circ} \mathrm{C}$, and $n$ - $\mathrm{Bu} 3 \mathrm{SnH} \mathrm{Sn}(0.21 \mathrm{~mL}, 1.2 \mathrm{mmol})$ was added. After stirring for $10 \mathrm{~min}$ at $-78{ }^{\circ} \mathrm{C}$, the mixture was added to a solution of alkyne $\mathbf{3 4}$ (65 $\mathrm{mg}, 0.20 \mathrm{mmol})$ in THF $(0.5 \mathrm{~mL})$. The mixture was stirred for $30 \mathrm{~min}$ at $-78{ }^{\circ} \mathrm{C}$, and $\mathrm{MeI}(0.12$ $\mathrm{mL})$ and DMPU $(60 \mu \mathrm{L})$ were added. The mixture was allowed to warm to room temperature, and the reaction was quenched by addition of a saturated solution of $\mathrm{NH}_{4} \mathrm{Cl}$ and extracted with $\mathrm{Et}_{2} \mathrm{O}$. The organic layer was washed with brine, dried over $\mathrm{Na}_{2} \mathrm{SO}_{4}$, and concentrated to give crude vinyl stannane.

To a solution of crude stannane in $\mathrm{Et}_{2} \mathrm{O}(2 \mathrm{~mL})$ at $0{ }^{\circ} \mathrm{C}$ was added $\mathrm{I}_{2}(101 \mathrm{mg}, 0.4 \mathrm{mmol})$. The mixture was stirred for $0.5 \mathrm{~h}$ at room temperature, diluted with water and extracted with hexane. The combined hexane layer was washed with brine, dried over $\mathrm{Na}_{2} \mathrm{SO}_{4}$, and concentrated. Flash chromatography (hexane-EtOAc $80: 1$ ) of the residue furnished $83 \mathrm{mg}(89 \%)$ of $\mathbf{3 5}:[\alpha]_{\mathrm{D}}^{23}-13.8$ 
(c 1.0, $\mathrm{CHCl}_{3}$ ); IR (neat) 2942, 2865, 1457, 1381, 1282, 1100, 1031, 1016, 882, $778 \mathrm{~cm}^{-1} ; 1 \mathrm{H}$ NMR (400 MHz, $\left.\mathrm{CDCl}_{3}\right) \delta 1.04(\mathrm{~d}, J=6.7 \mathrm{~Hz}, 3 \mathrm{H}), 1.07(\mathrm{~m}, 3 \mathrm{H}), 1.09(\mathrm{~s}, 18 \mathrm{H}), 1.55-1.75(\mathrm{~m}$, $5 \mathrm{H}), 1.81(\mathrm{~m}, 1 \mathrm{H}), 1.84(\mathrm{~s}, 3 \mathrm{H}), 2.05(\mathrm{~m}, 1 \mathrm{H}), 3.75(\mathrm{t}, J=5.9 \mathrm{~Hz}, 2 \mathrm{H}), 3.89(\mathrm{~d}, J=7.5 \mathrm{~Hz}, 1 \mathrm{H})$, $4.05(\mathrm{~m}, 1 \mathrm{H}), 6.28(\mathrm{~m}, 1 \mathrm{H}) ;{ }^{13} \mathrm{C} \mathrm{NMR}\left(100 \mathrm{Mz}, \mathrm{CDCl}_{3}\right) \delta 12.4,18.0,18.5,20.2,30.0,33.0,37.4$, 39.8, 63.7, 78.7, 78.7, 90.9, 147.9; HRMS (CI) $\mathrm{m} / z$ 467.1854([M+H] $]^{+}$; calcd for $\mathrm{C}_{20} \mathrm{H}_{40} \mathrm{O}_{2} \mathrm{ISi}$ : 467.1843).

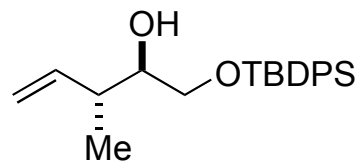

39

(2R,3R)-1-tert-Butyldiphenylsilanyloxy-3-methylpent-4-en-2-ol (39). To a solution of potassium tert-butoxide $(5.8 \mathrm{~g}, 45.4 \mathrm{mmol})$ in $\mathrm{THF}(250 \mathrm{~mL})$ at $-78{ }^{\circ} \mathrm{C}$ was added trans-2-butene and $n$-BuLi $(2.5 \mathrm{M}, 19 \mathrm{~mL}, 45.4 \mathrm{mmol})$. The mixture was stirred at $-45^{\circ} \mathrm{C}$ for $10 \mathrm{~min}$, the resulting orange solution was re-cooled to $-78 \quad{ }^{\circ} \mathrm{C}$ and a solution of (+)methoxydiisopinocampheylborane $(17 \mathrm{~g}, 48.9 \mathrm{mmol})$ in THF $(100 \mathrm{~mL})$ that had been pre-cooled to $-78{ }^{\circ} \mathrm{C}$ was added. After the mixture had been stirred at $-78{ }^{\circ} \mathrm{C}$ for $30 \mathrm{~min}$, a solution of boron trifluoride etherate $(6.2 \mathrm{~mL})$ was added slowly. The resulting solution was stirred at $-78{ }^{\circ} \mathrm{C}$ for $30 \mathrm{~min}$, after which a solution of aldehyde $\mathbf{3 8}(10.41 \mathrm{~g}, 34.9 \mathrm{mmol})$ was added slowly. The mixture was stirred at $-78{ }^{\circ} \mathrm{C}$ for $12 \mathrm{~h}$, then treated with $3 \mathrm{~N} \mathrm{NaOH}(19 \mathrm{~mL})$ and $30 \% \mathrm{H}_{2} \mathrm{O}_{2}(7.5$ $\mathrm{mL}$ ). The mixture was allowed to warm to room temperature and was stirred overnight. The organic layer was separated, washed with water and brine, dried over $\mathrm{Na}_{2} \mathrm{SO}_{4}$, and concentrated. Flash chromatography (hexane-EtOAc, 50:1) of the residue gave $6.54 \mathrm{~g}(52 \%, 90 \%$ ee) of $\mathbf{3 9}$ : $[\alpha]_{\mathrm{D}}^{23}+4.6\left(\mathrm{c} 1.30, \mathrm{CHCl}_{3}\right) ; \mathrm{IR}$ (neat) $3443,2958,2928,2856,1472,1457,1112,998,915,822$, 
738, $710 \mathrm{~cm}^{-1}$; ${ }^{1} \mathrm{H}$ NMR (400 MHz, $\left.\mathrm{CDCl}_{3}\right) \delta 1.05(\mathrm{~d}, \mathrm{~J}=6.9 \mathrm{~Hz}, 3 \mathrm{H}), 1.15(\mathrm{~s}, 9 \mathrm{H}), 2.38(\mathrm{~m}$, 1H), $2.49(\mathrm{~d}, \mathrm{~J}=2.9 \mathrm{~Hz}, 1 \mathrm{H}), 3.64(\mathrm{~m}, 2 \mathrm{H}), 3.73(\mathrm{~m}, 1 \mathrm{H}), 5.06-5.09(\mathrm{~m}, 2 \mathrm{H}), 5.85(\mathrm{~m}, 1 \mathrm{H})$, 7.45 (m, $6 \mathrm{H}), 5.72(\mathrm{~m}, 4) ;{ }^{13} \mathrm{C} \mathrm{NMR}\left(100 \mathrm{Mz}, \mathrm{CDCl}_{3}\right) \delta$ 16.6, 19.7, 27.3, 40.8, 66.4, 75.4, 115.6, 128.2, 130.2, 133.6, 136.0, 140.6; HRMS (EI) $\mathrm{m} / z 355.2075\left([\mathrm{M}+\mathrm{H}]^{+}\right.$; calcd for $\mathrm{C}_{22} \mathrm{H}_{31} \mathrm{O}_{2} \mathrm{Si}$ : 355.2093).

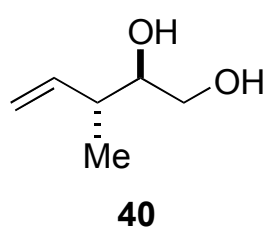

(2R,3R)-3-Methylpent-4-ene-1,2-diol (40). To a solution of ether 39 (6.34 g, $17.9 \mathrm{mmol})$ in THF $(500 \mathrm{~mL})$ at $0{ }^{\circ} \mathrm{C}$ was added tetra- $n$-butylammonium fluoride $(27 \mathrm{~mL}$ of a $1 \mathrm{M}$ solution, $27.0 \mathrm{mmol})$. The mixture was stirred at $0{ }^{\circ} \mathrm{C}$ for $1 \mathrm{~h}$ and the reaction was quenched by addition of saturated $\mathrm{NH}_{4} \mathrm{Cl}$. The organic layer was separated, washed with water and brine, dried over $\mathrm{Na}_{2} \mathrm{SO}_{4}$, and concentrated. Flash chromatography (hexane-EtOAc, 1:2) of the residue gave 1.46 $\mathrm{g}(71 \%)$ of $\mathbf{4 0}$ as a colorless oil: $[\alpha]_{\mathrm{D}}^{23}+14.0\left(\mathrm{c} 0.82, \mathrm{CHCl}_{3}\right)$; IR (neat) $3359,2964,2927,2878$, 1639, 1456, 1418, 1065, 998, 914, 873, $725 \mathrm{~cm}^{-1} ;{ }^{1} \mathrm{H}$ NMR $\left(400 \mathrm{MHz}, \mathrm{CDCl}_{3}\right) \delta 1.05(\mathrm{~d}, J=6.9$ $\mathrm{Hz}, 3 \mathrm{H}), 2.30(\mathrm{~m}, 1 \mathrm{H}), 2.74(\mathrm{~s}, 1 \mathrm{H}), 2.81(\mathrm{~s}, 1 \mathrm{H}), 3.55(\mathrm{~m}, 2 \mathrm{H}), 3.72(\mathrm{~d}, J=9.5 \mathrm{~Hz}, 1 \mathrm{H}), 5.11(\mathrm{~s}$, $1 \mathrm{H}), 5.15(\mathrm{~d}, J=3.6 \mathrm{~Hz}, 1 \mathrm{H}), 5.80(\mathrm{ddd}, J=1.2,9.7,17.9 \mathrm{~Hz}, 1 \mathrm{H}) ;{ }^{13} \mathrm{C} \mathrm{NMR}\left(100 \mathrm{Mz}, \mathrm{CDCl}_{3}\right) \delta$ 16.6, 30.1, 41.5, 65.3, 117.7, 140.6; HRMS (CI) $\mathrm{m} / z 117.0921\left([\mathrm{M}+\mathrm{H}]^{+}\right.$; calcd for $\mathrm{C}_{18} \mathrm{H}_{25} \mathrm{O}_{5}$ : 117.0916).

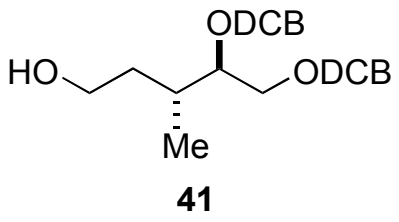


(2R,3R)-4,5-(2,6-Dichlorobenzyloxy)-3-methylpentan-1-ol (41). To a suspension of $\mathrm{NaH}$ $(1.96 \mathrm{~g}, 49.0 \mathrm{mmol})$ in dry DMF $(150 \mathrm{~mL})$ at $0{ }^{\circ} \mathrm{C}$ was added a solution of diol $40(1.90 \mathrm{~g}$, $16.4 \mathrm{mmol})$ in dry DMF $(14 \mathrm{~mL})$. The mixture was stirred for $5 \mathrm{~min}$ at $0{ }^{\circ} \mathrm{C}$, and a solution of 2,6-dichlorobenzyl bromide $(11.80 \mathrm{~g}, 49.0 \mathrm{mmol})$ in dry DMF $(20 \mathrm{~mL})$ was added slowly, followed by $\mathrm{Bu}_{4} \mathrm{NI}(18.1 \mathrm{~g}, 49.0 \mathrm{mmol})$. The mixture was stirred overnight at room temperature, the reaction was quenched by addition of saturated $\mathrm{NH}_{4} \mathrm{Cl}$ and the mixture was diluted with hexane. The phases were separated, and the aqueous layer was extracted with hexane $(2 \mathrm{x})$. The combined organic layer was washed with water and brine, dried over $\mathrm{Na}_{2} \mathrm{SO}_{4}$, and concentrated under vacuum. Flash chromatography (hexane-EtOAc, 20:1) of the residue afforded $8.0 \mathrm{~g}$ of a mixture of recovered 2,6-dichlorobenzyl bromide and $(3 R, 4 R)-4,5$-bis-(2,6dichlorobenzyloxy)-3-methyl-pent-1-ene: IR (neat) 2961, 2881, 1582, 1563, 1437, 1197, 1098, 1077, 1062, 994, 916, 776, 767, $728 \mathrm{~cm}^{-1} ;{ }^{1} \mathrm{H}$ NMR $\left(400 \mathrm{MHz}, \mathrm{CDCl}_{3}\right) \delta 1.05(\mathrm{~d}, J=7.0 \mathrm{~Hz}$, $3 \mathrm{H}), 2.55(\mathrm{~m}, 1 \mathrm{H}), 3.53(\mathrm{dd}, J=5.0,9.5 \mathrm{~Hz}, 1 \mathrm{H}), 3.66(\mathrm{dd}, J=5.1,9.9 \mathrm{~Hz}, 1 \mathrm{H}), 3.73(\mathrm{dd}, J=$ 5.4, $9.9 \mathrm{~Hz}, 1 \mathrm{H}), 4.84(\mathrm{~m}, 3 \mathrm{H}), 4.90-5.02(\mathrm{~m}, 3 \mathrm{H}), 5.85(\mathrm{ddd}, J=7.9,9.3,17.5 \mathrm{~Hz}, 1 \mathrm{H}), 7.20$ (m, 2H), $7.33(\mathrm{~m}, 4 \mathrm{H}) ;{ }^{13} \mathrm{C} \mathrm{NMR}\left(100 \mathrm{Mz}, \mathrm{CDCl}_{3}\right) \delta$ 16.7, 40.3, 67.4, 67.5, 68.0, 71.8, 82.3, 115.3, 128.7, 128.8, 130.1, 130.2, 130.4, 133.5, 133.9. 134.4, 137.4 (137.4), 137.6, 140.4; HRMS (FAB) $m / z 436.0147\left([\mathrm{M}]^{+}\right.$; calcd for $\left.\mathrm{C}_{20} \mathrm{H}_{20} \mathrm{O}_{2} \mathrm{Cl}_{2}{ }^{35} \mathrm{Cl}_{2}: 436.0159\right)$.

To a suspension of the mixture obtained above $(8.0 \mathrm{~g})$ in THF $(150 \mathrm{~mL})$ at $0{ }^{\circ} \mathrm{C}$ was added $\mathrm{BH}_{3} \cdot \mathrm{THF}(26 \mathrm{ml}$ of a $1 \mathrm{M}$ solution in THF, $26 \mathrm{mmol}$ ) and the mixture was stirred at room temperature for $10 \mathrm{~h}$. The reaction was quenched at $0{ }^{\circ} \mathrm{C}$ by addition of water $(5 \mathrm{~mL}), 10 \%$ aqueous $\mathrm{NaOH}(10 \mathrm{~mL})$, and $30 \% \mathrm{H}_{2} \mathrm{O}_{2}$. The mixture was stirred at room temperature overnight before the solvent was removed under vacuum. The residue was dissolved in $\mathrm{Et}_{2} \mathrm{O}$, washed with water and brine, dried over $\mathrm{MgSO}_{4}$, and concentrated. Flash chromatography (hexane-EtOAc, 
5:1) of the residue afforded $5.28 \mathrm{~g}$ (71\% over two steps) of 41 : $[\alpha]_{\mathrm{D}}^{23}-4.7\left(\mathrm{c} 1.20, \mathrm{CHCl}_{3}\right), \mathrm{IR}$ (neat) $3410,2958,2926,2878,1582,1563,1437,1197,1097,1059,993,767,727 \mathrm{~cm}^{-1} ;{ }^{1} \mathrm{H}$ NMR (400 MHz, $\left.\mathrm{CDCl}_{3}\right) \delta 0.97(\mathrm{~d}, J=7.0 \mathrm{~Hz}, 3 \mathrm{H}), 1.55(\mathrm{~m}, 1 \mathrm{H}), 1.73(\mathrm{~m}, 1 \mathrm{H}), 2.03(\mathrm{~m}, 1 \mathrm{H})$, $3.57-3.61(\mathrm{~m}, 2 \mathrm{H}), 3.69(\mathrm{td}, \mathrm{J}=6.4,10.8 \mathrm{~Hz}, 1 \mathrm{H}), 3.79(\mathrm{~m}, 2 \mathrm{H}), 4.81(\mathrm{~d}, \mathrm{~J}=10.4 \mathrm{~Hz}, 1 \mathrm{H}), 4.85$ $(\mathrm{s}, 2 \mathrm{H}), 5.03(\mathrm{~d}, \mathrm{~J}=10.4 \mathrm{~Hz}, 1 \mathrm{H}), 7.21(\mathrm{~m}, 2 \mathrm{H}), 7.33(\mathrm{~m}, 4 \mathrm{H}) ;{ }^{13} \mathrm{C} \mathrm{NMR}\left(100 \mathrm{Mz}, \mathrm{CDCl}_{3}\right) \delta$ 16.6, 32.6, 35.0, 60.7, 67.5, 68.0, 71.7, 83.1, 128.8 (128.8), 130.3 (130.3), 133.8, 134.0, 137.3 (137.3); HRMS (FAB) $m / z 451.0390\left([\mathrm{M}+\mathrm{H}]^{+}\right.$; calcd for $\left.\mathrm{C}_{20} \mathrm{H}_{23} \mathrm{O}_{3} \mathrm{Cl}^{35} \mathrm{Cl}_{3}: 451.0401\right)$.

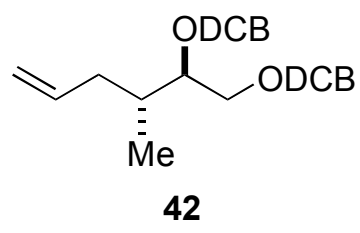

(4R,5R)-5,6-Bis-(2,6-dichlorobenzyloxy)-4-methylhex-1-ene (42). To a solution of alcohol $41(5.28 \mathrm{~g}, 11.7 \mathrm{mmol})$ in $\mathrm{CH}_{2} \mathrm{Cl}_{2}(230 \mathrm{~mL})$ at $0{ }^{\circ} \mathrm{C}$ was added Dess-Martin periodinane $(6.0 \mathrm{~g}$, $13.8 \mathrm{mmol}$ ). The mixture was stirred at $0{ }^{\circ} \mathrm{C}$ for $1 \mathrm{~h}$ and at room temperature for $1 \mathrm{~h}$. After removal of most of the solvent, the residue was taken up in $\mathrm{Et}_{2} \mathrm{O}(200 \mathrm{~mL})$. To the solution was added a mixture of saturated $\mathrm{NaHCO}_{3}(40 \mathrm{~mL}), \mathrm{Na}_{2} \mathrm{~S}_{2} \mathrm{O}_{3}(10 \%, 40 \mathrm{~mL})$, and brine $(20 \mathrm{~mL})$. The phases were separated, and the aqueous layer was extracted with $\mathrm{Et}_{2} \mathrm{O}(2 \mathrm{x})$. The combined organic layer was washed with water and brine, dried over $\mathrm{Na}_{2} \mathrm{SO}_{4}$, and concentrated to yield $5.20 \mathrm{~g}(99 \%)$ of $(3 R, 4 R)-4,5-\left(2,6\right.$-dichlorobenzyloxy)-3-methylpentanal: $[\alpha]_{\mathrm{D}}^{23}-4.3(\mathrm{c} \quad 1.50$, $\mathrm{CHCl}_{3}$ ), IR (neat) 2881, 2719, 1723, 1582, 1563, 1437, 1197, 1097, 1077, 1060, 778, 767, 728 $\mathrm{cm}^{-1} ;{ }^{1} \mathrm{H}$ NMR $\left(300 \mathrm{MHz}, \mathrm{CDCl}_{3}\right) \delta 0.94(\mathrm{~d}, J=6.8 \mathrm{~Hz}, 3 \mathrm{H}), 2.21(\mathrm{ddd}, J=2.5,8.1,16.4 \mathrm{~Hz}$, 1H), $2.42(\mathrm{~m}, 1 \mathrm{H}), 2.65(\mathrm{dd}, J=4.1,15.8 \mathrm{~Hz}, 1 \mathrm{H}), 3.41(\mathrm{~m}, 1 \mathrm{H}), 3.74(\mathrm{ddd}, J=4.3,10.3,19.4$ $\mathrm{Hz}, 1 \mathrm{H}), 4.72(\mathrm{~d}, J=10.4 \mathrm{~Hz}, 1 \mathrm{H}), 4.79(\mathrm{~d}, J=10.7 \mathrm{~Hz}, 1 \mathrm{H}), 4.84(\mathrm{~d}, J=10.7 \mathrm{~Hz}, 1 \mathrm{H}), 4.95(\mathrm{~d}$, 
$J=10.4, \mathrm{~Hz}, 1 \mathrm{H}), 7.17(\mathrm{~m}, 2 \mathrm{H}), 7.3(\mathrm{~m}, 4 \mathrm{H}), 9.64(\mathrm{~s}, 1 \mathrm{H}) ;{ }^{13} \mathrm{C} \mathrm{NMR}\left(100 \mathrm{Mz}, \mathrm{CDCl}_{3}\right) \delta ; \mathrm{HRMS}$ (FAB) $m / z$ 449.0229 ([M+H] $]^{+}$; calcd for $\left.\mathrm{C}_{20} \mathrm{H}_{21} \mathrm{O}_{3} \mathrm{Cl}_{4}: 449.0245\right)$.

To a suspension of methyltriphenylphosphonium bromide $(7.0 \mathrm{~g}, 19.6 \mathrm{mmol})$ in THF (100 $\mathrm{mL})$ at $0{ }^{\circ} \mathrm{C}$ was added $n$ - $\mathrm{BuLi}(6 \mathrm{~mL}$ of a $2.5 \mathrm{M}$ solution in hexane, $15.0 \mathrm{mmol})$. After the mixture had stirred for $1 \mathrm{~h}$, a solution of the aldehyde obtained above $(5.2 \mathrm{~g})$ in THF $(20 \mathrm{~mL})$ was added slowly. The resulting mixture was stirred at $0{ }^{\circ} \mathrm{C}$ for $1 \mathrm{~h}$ and the reaction was quenched by addition of saturated $\mathrm{NH}_{4} \mathrm{Cl}$ solution. The mixture was diluted with EtOAc and water. After the phases had separated, the aqueous phase was extracted with EtOAc $(2 \mathrm{x})$. The combined organic layer was washed with brine, dried over $\mathrm{Na}_{2} \mathrm{SO}_{4}$, and concentrated under vacuum. Flash chromatography (hexane-EtOAc, 15:1) of the residue afforded $4.6 \mathrm{~g}(90 \%)$ of $\mathbf{4 2}$ : $[\alpha]_{\mathrm{D}}^{23}-2.4\left(\mathrm{c} 1.03, \mathrm{CH}_{3} \mathrm{Cl}\right), \mathrm{IR}$ (neat) 3075, 2961, 2879, 1582, 1564, 1437, 1197, 1098, 1078, 1063, 994, 913, 777, 768, 728 $\mathrm{cm}^{-1} ;{ }^{1} \mathrm{H}$ NMR (400 MHz, $\left.\mathrm{CDCl}_{3}\right) \delta 0.91(\mathrm{~d}, J=6.4 \mathrm{~Hz}, 3 \mathrm{H}), 1.95$ (m, 2H), $2.33(\mathrm{~m}, 1 \mathrm{H}), 3.44(\mathrm{dd}, J=4.7,9.7 \mathrm{~Hz}, 1 \mathrm{H}), 3.75(\mathrm{dd}, \mathrm{J}=4.8,10.2 \mathrm{~Hz}, 1 \mathrm{H}), 3.83(\mathrm{dd}, J$ $=3.9,10.2 \mathrm{~Hz}, 1 \mathrm{H}), 4.79(\mathrm{~d}, J=10.2 \mathrm{~Hz}, 1 \mathrm{H}), 4.85(\mathrm{~s}, 2 \mathrm{H}), 4.96-5.04(\mathrm{~m}, 3 \mathrm{H}), 5.76(\mathrm{~m}, 1 \mathrm{H})$, $7.20(\mathrm{~m}, 2 \mathrm{H}), 7.33(\mathrm{~m}, 4 \mathrm{H}) ;{ }^{13} \mathrm{C} \mathrm{NMR}\left(100 \mathrm{Mz}, \mathrm{CDCl}_{3}\right) \delta$ 15.9, 35.1, 40.0, 67.1, 68.0, 71.2, 82.7, $116.3,128.7,128.8,130.1,130.2,133.9,134.4,137.4,137.4,138.0$; HRMS (CI) $m / z .447 .0459$ $\left([\mathrm{M}+\mathrm{H}]^{+}\right.$; calcd for $\left.\mathrm{C}_{21} \mathrm{H}_{23} \mathrm{O}_{2} \mathrm{Cl}_{4}: 447.0452\right)$.

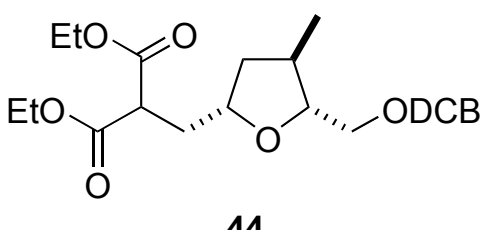

(2'S,4'R,5'R)-Diethyl 2-[(5'-(2,6-Dichlorobenzyloxymethyl)tetrahydro-4'-methylfuran-2'yl)methyl]malonate (44). To a suspension of $\mathrm{NaH}(122 \mathrm{mg}, 5.1 \mathrm{mmol})$ in DMF (8 mL) was 
added diethyl malonate $(0.81 \mathrm{~mL}, 5.1 \mathrm{mmol})$. The mixture was stirred for $30 \mathrm{~min}$ and a solution of iodide 43 (528 mg, $1.27 \mathrm{mmol}$ ) in DMF (2 mL) was added. The resulting mixture was stirred at $90{ }^{\circ} \mathrm{C}$ overnight. After the mixture had cooled to room temperature, the solvent was removed under vacuum. The residue was partioned in EtOAc and water, the phases were separated and the aqueous phase was extracted with EtOAc $(2 \mathrm{x})$. The combined organic layer was washed with brine, dried over $\mathrm{Na}_{2} \mathrm{SO}_{4}$, filtered, and concentrated. Flash chromatography (hexaneEtOAc, 5:1) of the residue produced $520 \mathrm{mg}(92 \%)$ of $44:[\alpha]_{\mathrm{D}}^{23}+1.2\left(\mathrm{c} 1.12, \mathrm{CHCl}_{3}\right)$; IR (neat) 2954, 2930, 2873, 1749, 1733, 1565, 1437, 1237, 1154, 1099, 1040, 781, $766 \mathrm{~cm}^{-1} ;{ }^{1} \mathrm{H}$ NMR $\left(400 \mathrm{MHz}, \mathrm{CDCl}_{3}\right) \delta 1.03(\mathrm{~d}, J=6.7 \mathrm{~Hz}, 3 \mathrm{H}), 1.25-1.31(\mathrm{~m}, 6 \mathrm{H}), 1.68(\mathrm{~m}, 1 \mathrm{H}), 1.79(\mathrm{~m}, 1 \mathrm{H})$, $1.99-2.19(\mathrm{~m}, 3 \mathrm{H}), 3.55-3.65(\mathrm{~m}, 4 \mathrm{H}), 4.02(\mathrm{~m}, 1 \mathrm{H}), 4.16-4.30(\mathrm{~m}, 4 \mathrm{H}), 4.81(\mathrm{~d}, J=10.7$ $\mathrm{Hz}, 1 \mathrm{H}), 4.87(\mathrm{~d}, J=10.7 \mathrm{~Hz}, 1 \mathrm{H}), 7.20(\mathrm{t}, J=8.0 \mathrm{~Hz}, 1 \mathrm{H}), 7.34(\mathrm{~d}, J=8.0 \mathrm{~Hz}, 2 \mathrm{H}) ;{ }^{13} \mathrm{C} \mathrm{NMR}$ $\left(100 \mathrm{Mz}, \mathrm{CDCl}_{3}\right) \delta 14.5,14.5,18.2,35.7,35.8,40.0,49.5,51.7,61.7,68.2,73.0,76.0,85.7$, $128.7,130.2,134.0,137.3,169.9,170.1$; HRMS $(\mathrm{FAB}) \mathrm{m} / z 447.1326\left([\mathrm{M}+\mathrm{H}]^{+}\right.$; calcd for $\left.\mathrm{C}_{21} \mathrm{H}_{29} \mathrm{O}_{6} \mathrm{Cl}_{2}: 447.1341\right)$.

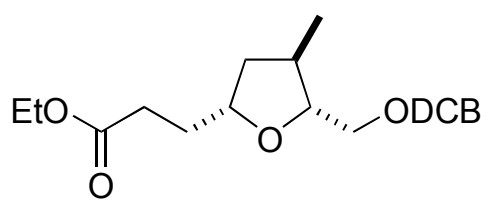

45

\section{$\left(2^{\prime} R, 4^{\prime} R, 5^{\prime} R\right)$-Ethyl $\quad 3$-[5'-(2,6-Dichlorobenzyloxy)methyltetrahydro-4'-methylfuran-2'-}

yl]propanoate (45). To a solution of diethyl ester 44 (2.46 g, $5.5 \mathrm{mmol})$ in DMSO (6 mL) was added $\mathrm{LiCl}(377 \mathrm{mg}, 8.9 \mathrm{mmol})$ and water $(0.43 \mathrm{~mL}, 23.7 \mathrm{mmol})$. The mixture was stirred for 7 h at $160{ }^{\circ} \mathrm{C}$. After being cooled to room temperature, the mixture was diluted with $\mathrm{Et}_{2} \mathrm{O}$ and $\mathrm{H}_{2} \mathrm{O}$ and the aqueous layer was extracted with $\mathrm{Et}_{2} \mathrm{O}$. The combined organic layer was washed with 
brine, dried over $\mathrm{Na}_{2} \mathrm{SO}_{4}$, and concentrated. Flash chromatography (hexane-EtOAc, 10:1) of the residue provided $1.59 \mathrm{~g}(77 \%)$ of $\mathbf{4 5}$ and $0.28 \mathrm{~g}(11 \%)$ of recovered 44: $[\alpha]_{\mathrm{D}}^{23}-2.04$ (c 1.37, $\mathrm{CHCl}_{3}$ ); IR (neat) 2957, 2934, 2872, 1734, 1582, 1564, 1437, 1371, 1249, 1197, 1175, 1101, 779, $767 \mathrm{~cm}^{-1} ;{ }^{1} \mathrm{H}$ NMR $\left(400 \mathrm{MHz}, \mathrm{CDCl}_{3}\right) \delta 1.05(\mathrm{~d}, J=6.7 \mathrm{~Hz}, 3 \mathrm{H}), 1.29(\mathrm{t}, J=7.2 \mathrm{~Hz}, 3 \mathrm{H})$, $1.66(\mathrm{~m}, 1 \mathrm{H}), 1.73-1.87(\mathrm{~m}, 3 \mathrm{H}), 2.07(\mathrm{~m}, 1 \mathrm{H}), 2.53(\mathrm{~m}, 2 \mathrm{H}), 3.57-3.65(\mathrm{~m}, 3 \mathrm{H}), 4.02(\mathrm{~m}$, 1H), $4.15(\mathrm{q}, J=7.1 \mathrm{~Hz}, 2 \mathrm{H}), 4.83(\mathrm{~d}, J=10.8 \mathrm{~Hz}, 1 \mathrm{H}), 4.88(\mathrm{~d}, J=10.8 \mathrm{~Hz}, 1 \mathrm{H}), 7.20(\mathrm{t}, J=$ $8.0 \mathrm{~Hz}, 1 \mathrm{H}), 7.34(\mathrm{~d}, J=8.0 \mathrm{~Hz}, 2 \mathrm{H}) ;{ }^{13} \mathrm{C} \mathrm{NMR}\left(100 \mathrm{Mz}, \mathrm{CDCl}_{3}\right) \delta$ 14.6, 18.3, 31.3, 31.8, 35.7, 39.7, 60.7, 68.2, 73.0, 77.6, 85.5, 128.7, 130.2, 134.0, 137.3, 174.1; HRMS (FAB) $\mathrm{m} / \mathrm{z} 375.1121$ $\left([\mathrm{M}+\mathrm{H}]^{+}\right.$; calcd for $\left.\mathrm{C}_{18} \mathrm{H}_{25} \mathrm{O}_{4} \mathrm{Cl}_{2}: 375.1130\right)$.

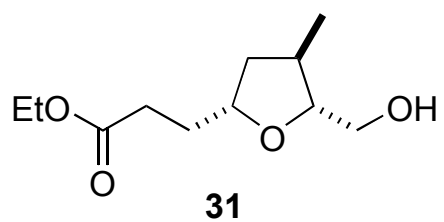

$\left(2^{\prime} R, 3^{\prime} R, 5^{\prime} R\right)-3-\left[5^{\prime}-\right.$ Hydroxymethyl-4'-methyltetrahydrofuran-2'-yl]propionic Acid Ethyl Ester (31). From 45. To a solution of $45(1.38 \mathrm{~g}, 3.68 \mathrm{mmol})$ in $\mathrm{CH}_{2} \mathrm{Cl}_{2}(35 \mathrm{~mL})$ at $-78{ }^{\circ} \mathrm{C}$ was added $\mathrm{BCl}_{3}\left(18.4 \mathrm{~mL}\right.$ of a $1 \mathrm{M}$ solution in $\left.\mathrm{CH}_{2} \mathrm{Cl}_{2}, 18.4 \mathrm{mmol}\right)$. The mixture was stirred for $2.5 \mathrm{~h}$ while the reaction temperature rose from $-78{ }^{\circ} \mathrm{C}$ to $0{ }^{\circ} \mathrm{C}$. The solution was re-cooled to $-78{ }^{\circ} \mathrm{C}$, and $\mathrm{MeOH}(1.5 \mathrm{~mL})$ was added. The mixture was slowly warmed to $0{ }^{\circ} \mathrm{C}$ and a saturated solution of $\mathrm{NH}_{4} \mathrm{Cl}$ was added. The phases were separated, the aqueous phase was extracted with $\mathrm{CH}_{2} \mathrm{Cl}_{2}(2 \mathrm{x})$, and the combined organic layer was washed with brine, dried over $\mathrm{Na}_{2} \mathrm{SO}_{4}$, and concentrated under vacuum. Flash chromatography (hexane-EtOAc, 3:1) of the residue gave 684 $\mathrm{mg}(86 \%)$ of 31: $[\alpha]_{\mathrm{D}}^{23}-9.7\left(\mathrm{c} 1.05, \mathrm{CHCl}_{3}\right)$ identical to material obtained from 29. 


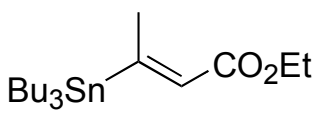

53

Ethyl (E)-3-Tributylstannyl-2-butenoate (53). To a solution of hexabutylditin (10.0 g, 17.20 mmol) in dry THF $(70 \mathrm{~mL})$ was added $n$-BuLi $(10.8 \mathrm{~mL}$ of a $1.6 \mathrm{M}$ solution in hexane, 17.28 mmol) at $-20{ }^{\circ} \mathrm{C}$ under argon. The pale yellow solution was stirred for 30 min and cooled to -50 ${ }^{\circ} \mathrm{C}$. $\mathrm{CuCN}(1.54 \mathrm{~g}, 17.21 \mathrm{mmol})$ was added, and the mixture was stirred for $30 \mathrm{~min}$ to give an orange solution of the cuprate reagent. The solution was cooled to $-100{ }^{\circ} \mathrm{C}$, and a mixture of ethyl-2-butynoate 52, $(1.61 \mathrm{~g}, 14.40 \mathrm{mmol})$ and dry EtOH $(890 \mu \mathrm{L}, 15.7 \mathrm{mmol})$ in dry THF (10 $\mathrm{mL}$ ) was added via cannula over $10 \mathrm{~min}$. The mixture was stirred for $4 \mathrm{~h}$ at $-78{ }^{\circ} \mathrm{C}$ and the reaction was quenched by addition of aqueous saturated $\mathrm{NH}_{4} \mathrm{Cl}$. The mixture was allowed to warm to room temperature and was diluted with $\mathrm{Et}_{2} \mathrm{O}$. The phases were separated and the aqueous layer was extracted with $\mathrm{Et}_{2} \mathrm{O}(2 \mathrm{x})$. The combined organic layer was washed with brine, dried over $\mathrm{Na}_{2} \mathrm{SO}_{4}$, and concentrated under vacuum. Flash chromatography (EtOAchexane, 1:50) of the residue afforded $5.28 \mathrm{~g}(90 \%)$ of $\mathbf{5 3}$ : IR (neat) 2957, 2927, 2872, 1715, 1599, 1464, 1338, 1175, 1039, $863 \mathrm{~cm}^{-1} ;{ }^{1} \mathrm{H}$ NMR $\left(300 \mathrm{MHz}, \mathrm{CDCl}_{3}\right) \delta 0.85-1.05(\mathrm{~m}, 6 \mathrm{H})$, $0.90(\mathrm{t}, J=7.2 \mathrm{~Hz}, 9 \mathrm{H}), 1.26-1.38(\mathrm{~m}, 6 \mathrm{H}), 1.30(\mathrm{t}, J=7.1 \mathrm{~Hz}, 3 \mathrm{H}), 1.46-1.56(\mathrm{~m}, 6 \mathrm{H}), 2.33$ $-1.48(\mathrm{~m}, 3 \mathrm{H}), 4.17(\mathrm{q}, J=7.1 \mathrm{~Hz}, 2 \mathrm{H}), 5.85-6.07(\mathrm{~m}, 1 \mathrm{H}) ;{ }^{13} \mathrm{C} \mathrm{NMR}\left(100 \mathrm{Mz}, \mathrm{CDCl}_{3}\right) \delta 9.8$, 14.0, 14.8, 22.8, 27.7, 29.4, 59.9, 128.5, 164.8, 169.5; HRMS (CI) $\mathrm{m} / \mathrm{z}$ 405.1812 ([M+H $]^{+}$; calcd for $\left.\mathrm{C}_{18} \mathrm{H}_{37} \mathrm{O}_{2}{ }^{120} \mathrm{Sn}: 405.1815\right)$.

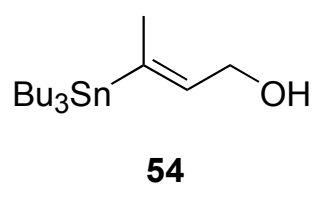


(E)-3-Tributylstannylbut-2-en-1-ol (54). To stannane 53 (2.22 g, $5.50 \mathrm{mmol})$ in dry THF (50 $\mathrm{mL})$ at $-78{ }^{\circ} \mathrm{C}$ was added dropwise neat diisobutylaluminum hydride $(2.35 \mathrm{~mL}, 13.20 \mathrm{mmol})$ under argon. The mixture was stirred at the same temperature for $2.5 \mathrm{~h}$, then and quenched with addition of a $1 \mathrm{M}$ aqueous solution of sodium and potassium tartrate $(20 \mathrm{~mL})$. The phases were separated and the aqueous layer was extracted with $\mathrm{Et}_{2} \mathrm{O}(2 \mathrm{x})$. The combined organic layer was washed with brine, dried over MgSO4, and concentrated under vacuum. Flash chromatography $\left(\mathrm{Et}_{2} \mathrm{O}\right.$-hexane, 1:4) of the residue afforded 1.95 (98\%) of 54: IR (neat) 3305, 2926, 2867, 1457, $1381,1061,1006,876 \mathrm{~cm}^{-1} ;{ }^{1} \mathrm{H}$ NMR $\left(300 \mathrm{MHz}, \mathrm{CDCl}_{3}\right) \delta 0.79-1.01(\mathrm{~m}, 6 \mathrm{H}), 0.90(\mathrm{t}, J=7.2$ $\mathrm{Hz}, 9 \mathrm{H}), 1.26-1.38(\mathrm{~m}, 6 \mathrm{H}), 1.45-1.56(\mathrm{~m}, 6 \mathrm{H}), 1.82-1.97(\mathrm{~m}, 3 \mathrm{H}), 4.26(\mathrm{t}, J=5.6 \mathrm{~Hz}, 2 \mathrm{H})$, $5.88-5.65(\mathrm{~m}, 1 \mathrm{H}) ;{ }^{13} \mathrm{C} \mathrm{NMR}\left(100 \mathrm{Mz}, \mathrm{CDCl}_{3}\right) \delta 9.5,14.1,19.8,27.8,29.5,59.2,139.7,142.8 ;$ HRMS (CI) $m / z 365.1547\left([\mathrm{M}-\mathrm{H}]^{+}\right.$; calcd for $\left.\mathrm{C}_{16} \mathrm{H}_{33} \mathrm{O}^{120} \mathrm{Sn}: 365.1553\right)$.

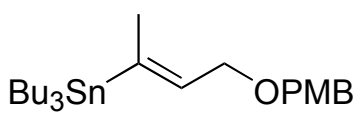

55

(E)-Tributyl-[3-(4-methoxybenzyloxy)-1-methylpropenyl]stannane (55). To a suspension of $\mathrm{NaH}(0.41 \mathrm{~g}, 17.08 \mathrm{mmol})$ in dry DMF $(20 \mathrm{~mL})$ at $0{ }^{\circ} \mathrm{C}$ was added a solution of alcohol 54 $(3.61 \mathrm{~g}, 9.88 \mathrm{mmol})$ in dry $\mathrm{DMF}(20 \mathrm{~mL})$. The mixture was stirred for $20 \mathrm{~min}$ at $0{ }^{\circ} \mathrm{C}$ and $4-$ methoxylbenzyl chloride $(1.90 \mathrm{ml}, 14.01 \mathrm{mmol})$ was added. The mixture was stirred overnight at room temperature and the reaction was quenched with aqueous saturated $\mathrm{NH}_{4} \mathrm{Cl}$. The mixture was diluted with $\mathrm{Et}_{2} \mathrm{O}$, the phases were separated and the aqueous layer was extracted with $\mathrm{Et}_{2} \mathrm{O}$ $(2 \mathrm{x})$. The organic layer was washed with water and brine, dried over $\mathrm{Na}_{2} \mathrm{SO}_{4}$, and concentrated under vacuum. Flash chromatography $\left(\mathrm{Et}_{2} \mathrm{O}\right.$-hexane, 1:50) of the residue gave $3.85 \mathrm{~g}(80 \%)$ of 55: IR (neat) 2955, 2925, 2851, 1613, 1513, 1248, 1087, 1039, 818 $\mathrm{cm}^{-1} ;{ }^{1} \mathrm{H}$ NMR (300MHz, 
$\left.\mathrm{CDCl}_{3}\right) 0.85(\mathrm{t}, J=7.3 \mathrm{~Hz}, 9 \mathrm{H}), 0.85(\mathrm{~m}, 6 \mathrm{H}), 1.30(\mathrm{~m}, 6 \mathrm{H}), 1.45(\mathrm{~m}, 6 \mathrm{H}), 1.72-1.92(\mathrm{~m}, 3 \mathrm{H})$, $3.79(\mathrm{~s}, 3 \mathrm{H}), 4.15(\mathrm{~m}, 2 \mathrm{H}), 4.43(\mathrm{~s}, 2 \mathrm{H}), 5.65-5.84(\mathrm{~m}, 1 \mathrm{H}), 6.65(\mathrm{~m}, 2 \mathrm{H}), 7.25(\mathrm{~m}, 2 \mathrm{H}) ;{ }^{13} \mathrm{C}$ NMR (100Mz, $\left.\mathrm{CDCl}_{3}\right)$ 9.5, 14.1, 20.0, 27.8, 29.6, 55.7, 66.3, 72.1, 114.2, 129.9, 131.0, 137.3, 143.5, 159.8; HRMS (CI) m/z $481.2117\left([\mathrm{M}-\mathrm{H}]^{+}\right.$cacld for $\mathrm{C}_{24} \mathrm{H}_{41} \mathrm{O}_{2}{ }^{120} \mathrm{Sn}:$ 481.2128).

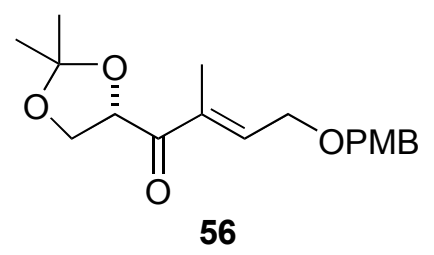

$(4 S)-(E)$-1-(2,2-Dimethyl-[1,3]dioxolan-4-yl)-4-(4-methoxybenzyloxy)-2-methylbut-2-en-1one (56). To a solution of stannane $55(2.73 \mathrm{~g}, 5.67 \mathrm{mmol})$ in dry THF $(10 \mathrm{~mL})$ at $-78{ }^{\circ} \mathrm{C}$ was added $n$-BuLi ( $3.15 \mathrm{~mL}$ of a 1.8M solution in hexane, $5.68 \mathrm{mmol}$ ) over $45 \mathrm{~min}$. After stirring for $1 \mathrm{~h}$, the yellow solution was transferred via cannula to a solution of amide 51 (1.07 g, 5.67 mmol) in dry THF $(10 \mathrm{~mL})$ that was precooled to $-78{ }^{\circ} \mathrm{C}$. The mixture was stirred for $1.5 \mathrm{~h}$ at $78{ }^{\circ} \mathrm{C}$ and the reaction was quenched by addition of saturated aqueous $\mathrm{NH}_{4} \mathrm{Cl}$. The mixture was diluted with $\mathrm{Et}_{2} \mathrm{O}$, the phases were separated and the aqueous phase was extracted with $\mathrm{Et}_{2} \mathrm{O}$. The combined organic layer was washed with brine, dried over $\mathrm{Na}_{2} \mathrm{SO}_{4}$, filtered, and concentrated under vacuum. Flash chromatography (hexane-EtOAc, 4:1) of the residue gave $1.28 \mathrm{~g}(71 \%)$ of $\mathbf{5 6}$ as a colorless oil: $[\alpha]_{\mathrm{D}}^{23}-23.5\left(\mathrm{c} 1.3, \mathrm{CHCl}_{3}\right)$; IR (neat) 2987, 2936, 2903, 2867, 2836, 1685, 1612, 1513, 1457, 1372, 1248, 1213, 1067, 911, $844 \mathrm{~cm}^{-1} ;{ }^{1} \mathrm{H}$ NMR (300 $\left.\mathrm{MHz}, \mathrm{CDCl}_{3}\right) \delta 1.42(\mathrm{~s}, 3 \mathrm{H}), 1.43(\mathrm{~s}, 3 \mathrm{H}), 1.77(\mathrm{~d}, J=1.2 \mathrm{~Hz}, 3 \mathrm{H}), 3.82(\mathrm{~s}, 3 \mathrm{H}), 4.07$ (dd, $J=$ $6.3,8.3 \mathrm{~Hz}, 1 \mathrm{H}), 4.21(\mathrm{dd}, J=7.3,8.4 \mathrm{~Hz}, 1 \mathrm{H}), 4.26(\mathrm{~d}, J=5.2 \mathrm{~Hz}, 2 \mathrm{H}), 4.5(\mathrm{~s}, 2 \mathrm{H}), 5.06(\mathrm{dd}, J$ $=6.4,7.1 \mathrm{~Hz}, 1 \mathrm{H}), 6.73(\mathrm{td}, J=1.2,5.4 \mathrm{~Hz}, 1 \mathrm{H}), 6.82(\mathrm{~m}, 2 \mathrm{H}), 7.25(\mathrm{~m}, 2 \mathrm{H}) ;{ }^{13} \mathrm{C} \mathrm{NMR}(100 \mathrm{Mz}$ 
$\left.\mathrm{CDCl}_{3}\right) \delta 12.3,26.0,26.3,55.7,67.1,67.4,73.2,76.9,111.2,114.3,130.0,136.2,141.6,159.9$, 197.3; HRMS (CI) $m / z, 321.1700\left([\mathrm{M}+\mathrm{H}]^{+}\right.$; calcd for $\left.\mathrm{C}_{18} \mathrm{H}_{25} \mathrm{O}_{5}: 321.1702\right)$.

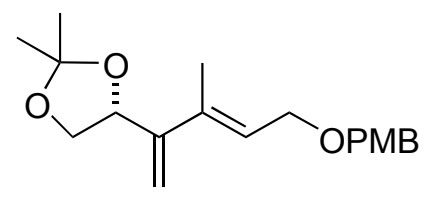

57

\section{(4R)-(E)-4-[4-(4-Methoxybenzyloxy)-2-methyl-1-methylenebut-2-enyl]-2,2-dimethyl-[1,3]-}

dioxolane (57). To a suspension of methyltriphenylphosphonium bromide (7.84 g, $21.6 \mathrm{mmol})$ in dry THF $(60 \mathrm{~mL})$ at $-78{ }^{\circ} \mathrm{C}$ was added $n$-BuLi $(10.45 \mathrm{~mL}$ of a $1.98 \mathrm{M}$ solution in hexane, 20.7 mmol). The mixture was warmed to $0{ }^{\circ} \mathrm{C}$ and stirred for $1 \mathrm{~h}$. The mixture was cooled to $-78{ }^{\circ} \mathrm{C}$ and a solution of $\mathbf{5 6}(6.30 \mathrm{~g}, 19.7 \mathrm{mmol})$ in THF (40 mL) was added slowly. The resulting mixture was allowed to warm to $0{ }^{\circ} \mathrm{C}$, stirred for $5 \mathrm{~h}$ and the reaction was quenched by addition of saturated aqueous $\mathrm{NH}_{4} \mathrm{Cl}$. The mixture was diluted with $\mathrm{Et}_{2} \mathrm{O}$, the phases were separated and the aqueous phase was extracted with $\mathrm{Et}_{2} \mathrm{O}$. The combined organic phase was washed with brine, dried over $\mathrm{Na}_{2} \mathrm{SO}_{4}$, and concentrated under vacuum. Flash chromatography (hexaneEtOAc, 10:1) of the residue yielded $5.25 \mathrm{~g}(84 \%)$ of 57: $[\alpha]_{\mathrm{D}}^{23}-34.2$ (c 1.15, $\mathrm{CHCl}_{3}$ ); IR (neat) 2997, 2938, 2850, 1608, 1511, 1456, 1368, 1296, 1241, 1170, 1060, 1039, $824 \mathrm{~cm}^{-1}$; ${ }^{1} \mathrm{H}$ NMR $\left(300 \mathrm{MHz}, \mathrm{CDCl}_{3}\right) \delta 1.43(\mathrm{~s}, 3 \mathrm{H}), 1.48(\mathrm{~s}, 3 \mathrm{H}), 1.81(3 \mathrm{H}), 3.55(\mathrm{t}, J=7.8 \mathrm{~Hz}, 1 \mathrm{H}), 3.80(\mathrm{~s}, 3 \mathrm{H})$, $4.14(\mathrm{~d}, J=6.2 \mathrm{~Hz}, 1 \mathrm{H}), 4.27(\mathrm{dd}, J=6.6,8.0 \mathrm{~Hz}, 1 \mathrm{H}), 4.45(\mathrm{~s}, 2 \mathrm{H}), 4.89(\mathrm{t}, J=7.0 \mathrm{~Hz}, 1 \mathrm{H})$, $5.21(\mathrm{~s}, 1 \mathrm{H}), 5.46(\mathrm{~s}, 1 \mathrm{H}), 5.55(\mathrm{t}, J=6.0 \mathrm{~Hz}, 1 \mathrm{H}), 6.87(\mathrm{~m}, 2 \mathrm{H}), 7.26(\mathrm{~m}, 2 \mathrm{H}) ;{ }^{13} \mathrm{C} \mathrm{NMR}(100 \mathrm{Mz}$, $\left.\mathrm{CDCl}_{3}\right) \delta 15.4,26.0,26.7,55.7,67.2,70.9,72.6,75.7,109.4,111.4,114.3,124.5,129.9,130.6$, 136.2, 147.2, 159.7; HRMS (CI) $m / z 318.1830$ ([M]+; calcd for $\mathrm{C}_{19} \mathrm{H}_{26} \mathrm{O}_{4}: 318.1831$ ). 


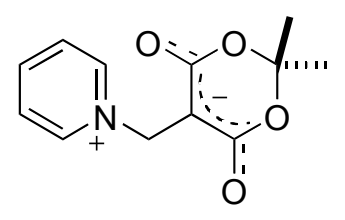

60

\section{1-[(6-Hydroxy-2,2-dimethyl-4-oxo-4H-1,3-dioxin-5-yl)methyl]pyridinium Hydroxide,}

Inner Salt (60). Meldrum's acid 59, (5.41 g, $27.5 \mathrm{mmol})$ was dissolved in dry pyridine (35 mL) and to the colorless solution was added formaldehyde $(2.80 \mathrm{~mL}$ of a $37 \%$ aqueous solution, 37.5 mmol) in one portion. The yellow mixture was stirred for $2 \mathrm{~h}$ and the solvent was removed under vacuum at $55^{\circ} \mathrm{C}$, after which a crystalline precipitate was formed. The crystals were collected and washed with hexane $(100 \mathrm{~mL})$ to give pure $\mathbf{6 0}$ as a pale yellow solid. The product was dried under vacuum overnight to yield $8.20 \mathrm{~g}(93 \%)$ of $\mathbf{6 0}:{ }^{1} \mathrm{H}$ NMR (400 $\mathrm{MHz}, \mathrm{CDCl}_{3}$ ) $\delta 1.64(\mathrm{~s}, 6 \mathrm{H}), 5.57(\mathrm{br} \mathrm{s}, 2 \mathrm{H}), 7.73(\mathrm{t}, J=6.6 \mathrm{~Hz}, 2 \mathrm{H}), 8.16(\mathrm{t}, J=7.5 \mathrm{~Hz}, 2 \mathrm{H}), 8.99(\mathrm{~d}, J=5.5$ $\mathrm{Hz}, 1 \mathrm{H})$.

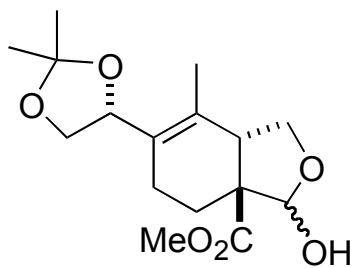

67

\section{(3aS,7aS,4'R)-6-(2',2'-Dimethyl-[1',3']dioxolan-4'-yl)-3-hydroxy-7-methyl-1,4,5,7a-} tetrahydroisobenzofuran-3a-carboxylic Acid Methyl Ester (67). To a solution of 65 (22 mg, $0.07 \mathrm{mmol})$ in dry THF $(1 \mathrm{~mL})$ under argon at $-35^{\circ} \mathrm{C}$ was added DIBAL-H $(80 \mu \mathrm{L}$ of a $1 \mathrm{M}$ solution in hexane, $0.08 \mathrm{mmol}$ ). The mixture was stirred at $-35{ }^{\circ} \mathrm{C}$ for $24 \mathrm{~h}$ and the reaction was quenched by the addition of an aqueous solution of Rochelle's salt. The mixture was diluted with $\mathrm{Et}_{2} \mathrm{O}$ and was warmed to room temperature. The organic layer was separated, washed with 
brine, dried over $\mathrm{Na}_{2} \mathrm{SO}_{4}$, and concentrated under vacuum. Flash chromatography (hexaneEtOAc, 2:1) of the residue gave $17 \mathrm{mg}(75 \%)$ of $\mathbf{6 7}$ as a $12: 1$ mixture of diastereoisomers: major isomer, $[\alpha]_{\mathrm{D}}^{23}-20.8\left(\mathrm{c} 0.36, \mathrm{CHCl}_{3}\right)$; IR (neat) 3419, 2984, 2935, 2886, 1742, 1454, 1372, 1259 , 1208, 1179, 1050, 926, $860 \mathrm{~cm}^{-1} ;{ }^{1} \mathrm{H}$ NMR (400 MHz, $\left.\mathrm{CDCl}_{3}\right) \delta 1.39$ (s, 3H), 1.44 (s, 3H), 1.50 $-1.80(\mathrm{~m}, 2 \mathrm{H}), 1.74(\mathrm{~s}, 3 \mathrm{H}), 2.22(\mathrm{~m}, 1 \mathrm{H}), 2.38(\mathrm{~m}, 1 \mathrm{H}), 2.71(\mathrm{br} \mathrm{s}, 1 \mathrm{H}), 3.38(\mathrm{t}, J=9.0 \mathrm{~Hz}, 1 \mathrm{H})$ $3.56(\mathrm{t}, J=8.1 \mathrm{~Hz}, 1 \mathrm{H}), 3.70(\mathrm{t}, J=8.1 \mathrm{~Hz}, 1 \mathrm{H}), 3.73(\mathrm{~s}, 3 \mathrm{H}), 3.97(\mathrm{dd}, J=7.0,8.1 \mathrm{~Hz}, 1 \mathrm{H})$, $4.50(\mathrm{dd}, J=8.2,9.1 \mathrm{~Hz}, 1 \mathrm{H}), 5.02(\mathrm{t}, J=7.3 \mathrm{~Hz}, 1 \mathrm{H}), 5.25(\mathrm{~s}, 1 \mathrm{H}) ;{ }^{13} \mathrm{C} \mathrm{NMR}\left(100 \mathrm{Mz}, \mathrm{CDCl}_{3}\right)$ $\delta 18.7,20.2,26.0,26.7,43.6,52.6,57.6,67.3,73.3,74.4,103.5,109.4,127.1,130.7,172.8$; HRMS (CI) $m / z 312.1567$ ([M] $]^{+}$; calcd for $\mathrm{C}_{16} \mathrm{H}_{24} \mathrm{O}_{6}: 312.1573$ ).

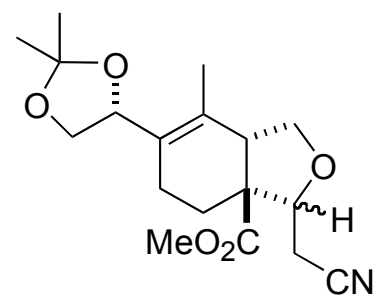

71

\section{(3aS,7aS,4'R)-3-Cyanomethyl-6-(2',2'-dimethyl-[1',3']-dioxolan-4'-yl)-7-methyl-1,4,5,7a-}

tetrahydroisobenzofuran-3a-carboxylic Acid Methyl Ester (71). To a solution of diethyl cyanomethylphosphonate $(69,20 \mu \mathrm{L}, 0.12 \mathrm{mmol})$ in dry THF $(0.5 \mathrm{~mL})$ at $0{ }^{\circ} \mathrm{C}$ was added $n$ $\operatorname{BuLi}(46 \mu \mathrm{L}$ of a $2.5 \mathrm{M}$ in hexane solution, $0.12 \mathrm{mmol}$ ). The mixture was stirred for $10 \mathrm{~min}$, and a solution of $67(18 \mathrm{mg}, 0.06 \mathrm{mmol})$ in dry THF $(0.5 \mathrm{~mL})$ was added slowly. The mixture was stirred overnight at room temperature and the reaction was quenched by addition of saturated $\mathrm{NH}_{4} \mathrm{Cl}$. The mixture was diluted with $\mathrm{Et}_{2} \mathrm{O}$, the phases were separated and the aqueous phase was extracted with $\mathrm{Et}_{2} \mathrm{O}(2 \mathrm{x})$. The combined organic layer was washed with brine, dried over $\mathrm{Na}_{2} \mathrm{SO}_{4}$, and concentrated under vacuum. Flash chromatography (hexane-EtOAc, 3:1) of the 
residue yielded $17 \mathrm{mg}(86 \%)$ of $\mathbf{7 1}$ as a 2:1 mixture of diastereoisomers: IR (neat) 2984, 2933, 2882, 2253, 1732, 1454, 1437, 1382, 1370, 1261, 1212, 1057, 858, $795 \mathrm{~cm}^{-1} ;{ }^{1} \mathrm{H}$ NMR (400 $\left.\mathrm{MHz}, \mathrm{CDCl}_{3}\right)$ (major) $\delta 1.39(\mathrm{~s}, 3 \mathrm{H}), 1.42(\mathrm{~s}, 3 \mathrm{H}), 1.60(\mathrm{~m}, 1 \mathrm{H}), 1.78-2.10(\mathrm{~m}, 3 \mathrm{H}), 2.55(\mathrm{dd}, J$ $=8.4,16.7 \mathrm{~Hz}, 1 \mathrm{H}), 2.75(\mathrm{dd}, J=4.3,16.7 \mathrm{~Hz}, 1 \mathrm{H}), 3.25(\mathrm{~m}, 1 \mathrm{H}), 3.51(\mathrm{~m}, 1 \mathrm{H}), 3.68(\mathrm{dd}, J=$ 8.1, $9.0 \mathrm{~Hz}, 1 \mathrm{H}), 3.70(\mathrm{~s}, 3 \mathrm{H}), 3.98(\mathrm{~m}, 1 \mathrm{H}), 4.21(\mathrm{dd}, J=4.30,8.4 \mathrm{~Hz}, 1 \mathrm{H}), 4.32(\mathrm{dd}, J=8.1$, $10.8 \mathrm{~Hz}, 1 \mathrm{H}), 5.00(\mathrm{dd}, J=6.2,6.8 \mathrm{~Hz}, 1 \mathrm{H}) ;{ }^{13} \mathrm{C} \mathrm{NMR}\left(100 \mathrm{Mz}, \mathrm{CDCl}_{3}\right)$ (major) $\delta 18.5,19.4$, $20.3,21.8,26.7,28.5,48.1,53.0,67.3,72.8,74.3,80.1,109.5,117.7,127.5,129.9,173.2,213.0$ HRMS (CI) $\mathrm{m} / z 335.1729$ ([M] ${ }^{+}$; calcd for $\left.\mathrm{C}_{18} \mathrm{H}_{25} \mathrm{O}_{5} \mathrm{~N}: 335.1733\right)$.

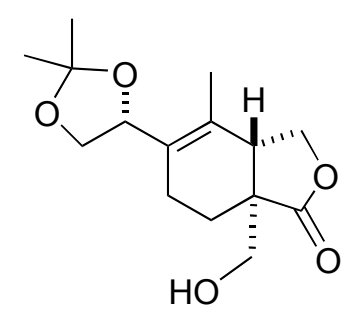

73

\section{(3aS,7aS,4'R)-5-(2',2'-Dimethyl-[1',3']-dioxolan-4'-yl)-7a-hydroxymethyl-4-methyl-}

3a,6,7,7a-tetrahydro-3H-isobenzofuran-1-one (73). To a solution of $\mathbf{6 1}(312 \mathrm{mg}, 0.66 \mathrm{mmol})$ in a mixture of $\mathrm{CH}_{2} \mathrm{Cl}_{2}(6.0 \mathrm{~mL})$ and $\mathrm{pH} 7$ buffer $(0.3 \mathrm{~mL})$ at $0{ }^{\circ} \mathrm{C}$ was added DDQ $(180 \mathrm{mg}$, $0.79 \mathrm{mmol})$. The mixture was stirred for $8 \mathrm{~h}$ at room temperature and $\mathrm{NaHCO}_{3}$ powder $(224 \mathrm{mg}$, $2.6 \mathrm{mmol}$ ) was added. Removal of solvent gave crude $\mathbf{6 4}$ which was dried under vacuum.

The crude 64 obtained above was suspended in a mixture of THF $(6.0 \mathrm{~mL})$ and $\mathrm{H}_{2} \mathrm{O}(0.75$ $\mathrm{mL})$. To the mixture at $-10{ }^{\circ} \mathrm{C}$ was added $\mathrm{NaBH}_{4}(240 \mathrm{mg}, 6.3 \mathrm{mmol})$ and the mixture was stirred at $-10{ }^{\circ} \mathrm{C}$ for $6 \mathrm{~h}$ and was neutralized by addition of $1 \mathrm{~N}$ citric acid to $\mathrm{pH}$ 6-7. Removal of solvent under vacuum gave crude $\mathbf{7 2}$ which was dried under vacuum overnight. 
To a suspension of crude 72 obtained above in THF $(60 \mathrm{~mL})$ at $-10{ }^{\circ} \mathrm{C}$ was added $\mathrm{Et}_{3} \mathrm{~N}(0.54$ $\mathrm{mL}, 3.9 \mathrm{mmol})$ and methyl chloroformate $(0.3 \mathrm{~mL}, 3.9 \mathrm{mmol})$. The mixture was stirred at room temperature for $60 \mathrm{~h}$. After removal of solvent under vacuum, the residue was diluted with EtOAc and $\mathrm{H}_{2} \mathrm{O}$. The layers were separated and the aqueous layer was extracted with EtOAc (2 $\mathrm{x}$ ). The combined organic extract was washed with brine, dried over $\mathrm{Na}_{2} \mathrm{SO}_{4}$, and concentrated under vacuum. Flash chromatography (hexane-EtOAc, 1:1) of the residue afforded $110 \mathrm{mg}$ $(61 \%)$ of 73: $[\alpha]_{\mathrm{D}}^{23}+25.6\left(c 1.8 \mathrm{CHCl}_{3}\right)$; IR (neat) 3457, 2984, 2924, 1770, 1453, 1372, 1214, 1057, 984, $855 \mathrm{~cm}^{-1} ;{ }^{1} \mathrm{H}$ NMR (400 MHz, $\left.\mathrm{CDCl}_{3}\right) \delta 1.38(\mathrm{~s}, 3 \mathrm{H}), 1.44(\mathrm{~s}, 3 \mathrm{H}), 1.68(\mathrm{~m}, 1 \mathrm{H}), 1.75$ (s, 3H), $2.22(\mathrm{~m}, 2 \mathrm{H}), 2.52(\mathrm{~m}, 1 \mathrm{H}), 3.16(\mathrm{t}, J=9.8 \mathrm{~Hz}, 1 \mathrm{H}), 3.58(\mathrm{t}, J=8.0 \mathrm{~Hz}, 1 \mathrm{H}), 3.79(\mathrm{dd}, J$ $=7.4,12.4 \mathrm{~Hz}, 1 \mathrm{H}), 3.86(\mathrm{dd}, J=4.3,11.5 \mathrm{~Hz}, 1 \mathrm{H}), 4.01(\mathrm{dd}, J=6.1,8.2 \mathrm{~Hz}, 1 \mathrm{H}), 4.38-4.41$ $(\mathrm{m}, 1 \mathrm{H}), 5.02(\mathrm{t}, J=7.4 \mathrm{~Hz}, 1 \mathrm{H}) ;{ }^{13} \mathrm{C} \mathrm{NMR}\left(100 \mathrm{Mz}, \mathrm{CDCl}_{3}\right) \delta 15.1,21.9,25.3,25.9,26.7,47.5$, 48.0, 61.4, 67.8, 69.0, 74.1, 109.6, 127.2, 130.0 179.3; HRMS (FAB) $m / z$ 282.1473(calcd for $\left.\mathrm{C}_{15} \mathrm{H}_{22} \mathrm{O}_{5}, 282.1467\right)$.

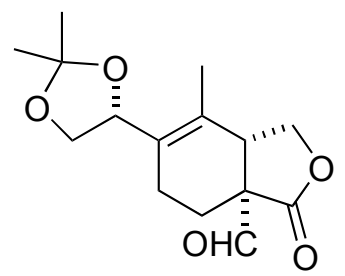

74

(3aS,7aS,4'R)-6-(2',2'-Dimethyl-[1',3']-dioxolan-4'-yl)-7-methyl-3-oxo-1,4,5,7a-

tetrahydroisobenzofuran-3a-carbaldehyde (74). To a solution of oxalyl chloride $(32 \mu \mathrm{L}, 0.36$ mmol) in $\mathrm{CH}_{2} \mathrm{Cl}_{2}(0.5 \mathrm{~mL})$ at $-78{ }^{\circ} \mathrm{C}$ was added a solution of DMSO $(51 \mu \mathrm{L}, 0.72 \mathrm{mmol})$ in $\mathrm{CH}_{2} \mathrm{Cl}_{2}(0.4 \mathrm{~mL})$. The mixture was stirred for $5 \mathrm{~min}$, and a solution of alcohol 73 (68.5 $\mathrm{mg}, 0.24$ mmol $)$ in $\mathrm{CH}_{2} \mathrm{Cl}_{2}(1.8 \mathrm{~mL})$ was added. The mixture was stirred for $10 \mathrm{~min}$ at $-78{ }^{\circ} \mathrm{C}, \mathrm{Et}_{3} \mathrm{~N}(0.17$ 
$\mathrm{mL}, 1.2 \mathrm{mmol}$ ) was added, and the mixture was allowed to warm to room temperature slowly. The reaction was quenched by addition of saturated aqueous $\mathrm{NaHCO}_{3}$ and the mixture was diluted with $\mathrm{CH}_{2} \mathrm{Cl}_{2}$. The phases were separated, the aqueous phase was extracted with $\mathrm{CH}_{2} \mathrm{Cl}_{2}$ $(2 \mathrm{x})$, and the combined organic extract was washed with brine, dried over $\mathrm{Na}_{2} \mathrm{SO}_{4}$, and concentrated under vacuum. Flash chromatography (hexane-EtOAc, 4:1) of the residue afforded $60.5 \mathrm{mg}(89 \%)$ of 74 as prisms: $\mathrm{mp} 118-121{ }^{\circ} \mathrm{C} ;[\alpha]_{\mathrm{D}}^{23}-6.6\left(\mathrm{c} 1.1, \mathrm{CHCl}_{3}\right)$; IR (neat) 2933, 1782, 1716, 1455, 1371, 1212, 1155, 1055, 982, $856 \mathrm{~cm}^{-1} ;{ }^{1} \mathrm{H}$ NMR $\left(300 \mathrm{MHz}, \mathrm{CDCl}_{3}\right) \delta 1.36(\mathrm{~s}$, 3H), $1.43(\mathrm{~s}, 3 \mathrm{H}), 1.76(\mathrm{~d}, J=1.7 \mathrm{~Hz}, 3 \mathrm{H}), 1.92(\mathrm{~m}, 1 \mathrm{H}), 2.32(\mathrm{~m}, 1 \mathrm{H}), 2.60(\mathrm{~m}, 2 \mathrm{H}), 3.24(\mathrm{~m}$, 1H), $3.55(\mathrm{t}, J=7.9 \mathrm{~Hz}, 1 \mathrm{H}), 4.03(\mathrm{~d}, J=6.9,8.3 \mathrm{~Hz}, 1 \mathrm{H}), 4.55(\mathrm{~m}, 2 \mathrm{H}), 5.00(\mathrm{t}, J=7.7 \mathrm{~Hz}$, 1H), $9.6(\mathrm{~d}, J=1.3 \mathrm{~Hz}, 1 \mathrm{H}) ;{ }^{13} \mathrm{C} \mathrm{NMR}\left(100 \mathrm{Mz}, \mathrm{CDCl}_{3}\right) \delta 15.3,22.2,24.3,25.7,26.7,47.8,67.8$, 69.0, 74.1, 77.0, 109.8, 127.0, 132.1, 180.2, 196.4; HRMS (FAB) m/z 279.1232 ([M-H] ${ }^{+}$; calcd for 279.1233).

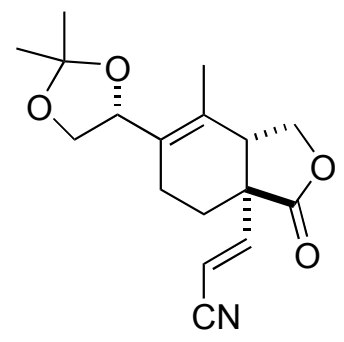

75

$\left(3 \mathrm{a} R, 7 \mathrm{a} S, 4^{\prime \prime} R\right)-(E)-3-\left[6 '-\left(2^{\prime \prime}, 2^{\prime \prime}-D i m e t h y l-\left[1^{\prime \prime}, 3^{\prime \prime}\right]-d i o x o l a n-4{ }^{\prime \prime}-y l\right)-7-m e t h y l-3-o x o-1,4,5,7 a-\right.$ tetrahydroisobenzofuran-3a-yl]acrylonitrile (75). To a solution of diethyl (cyanomethyl)phosphonate $(\mathbf{6 9}, 0.12 \mathrm{~mL}, 0.74 \mathrm{mmol})$ in $\mathrm{THF}(0.8 \mathrm{~mL})$ at $0{ }^{\circ} \mathrm{C}$ was added $n$ $\operatorname{BuLi}(0.16 \mathrm{~mL}$ of a $2.2 \mathrm{M}$ solution in hexane, $0.35 \mathrm{mmol})$. The mixture was stirred at $0{ }^{\circ} \mathrm{C}$ for 20 min and at room temperature for $20 \mathrm{~min}$. The mixture was re-cooled to $0{ }^{\circ} \mathrm{C}$ and a solution of the aldehyde $74(50.2 \mathrm{mg}, 0.18 \mathrm{mmol})$ in THF $(1.0 \mathrm{~mL})$ was added. The solution was allowed to 
warm to room temperature and stirring was continued for $2 \mathrm{~h}$. The reaction was quenched by addition of saturated aqueous $\mathrm{NaHCO}_{3}$, and the mixture was diluted with EtOAc. The layers were separated and the aqueous layer was extracted with EtOAc $(2 \mathrm{x})$. The combined organic extract was washed with brine, dried over $\mathrm{Na}_{2} \mathrm{SO}_{4}$, and concentrated under vacuum. The residue was purified by chromatography (hexane-EtOAc, $2: 1)$ to give $46.5 \mathrm{mg}(85 \%)$ of $\mathbf{7 5}:[\alpha]_{\mathrm{D}}^{23}+1.8(c$ 1.0 $\mathrm{CHCl}_{3}$ ); IR (neat) 2923, 2853, 2226, 1778, 1458, 1372 1210, 1155, 1110, 1056, 978, $858 \mathrm{~cm}^{-}$ ${ }^{1} ;{ }^{1} \mathrm{H}$ NMR (400 MHz, CDCl $)$ $\delta 1.39$ (s, 3H), 1.45 (s, 3H), 1.75 (s, 3H), 1.91 (m, 1H), 2.18 (m, 1H), $2.22(\mathrm{~m}, 1 \mathrm{H}), 2.45(\mathrm{~m}, 1 \mathrm{H}), 3.13(\mathrm{~m}, 1 \mathrm{H}), 3.55(\mathrm{t}, J=8.0 \mathrm{~Hz}, 1 \mathrm{H}), 4.03(\mathrm{t}, J=8.4 \mathrm{~Hz}, 1 \mathrm{H})$, $4.06(\mathrm{dd}, J=3.3,8.7 \mathrm{~Hz}, 1 \mathrm{H}), 4.45(\mathrm{dd}, J=6.7,8.5 \mathrm{~Hz}, 1 \mathrm{H}), 5.03(\mathrm{t}, J=7.4 \mathrm{~Hz}, 1 \mathrm{H}), 5.66(\mathrm{~d}, J$ $=17.1 \mathrm{~Hz}, 1 \mathrm{H}), 6.88(\mathrm{~d}, J=17.1 \mathrm{~Hz}, 1 \mathrm{H}) ;{ }^{13} \mathrm{C} \mathrm{NMR}\left(100 \mathrm{Mz}, \mathrm{CDCl}_{3}\right) \delta 15.2,21.9,25.5,26.6$, 28.9, 48.6, 49.5, 67.6, 68.5, 73.9, 105.0, 109.7. 116.4, 125.2. 131.5, 148.8, 175.4; HRMS (CI) $m / z 303.1470$ (calcd for $\mathrm{C}_{17} \mathrm{H}_{21} \mathrm{O}_{4} \mathrm{~N}: 303.1471$ ).

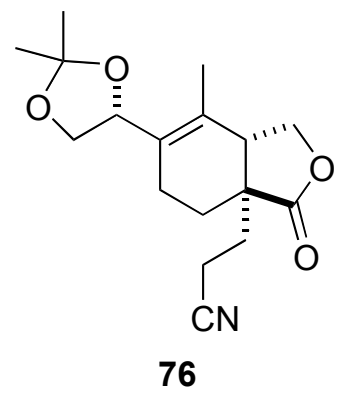

\section{$\left(3 \mathrm{a} R, 7 \mathrm{a} S, 44^{\prime \prime} R\right)-3-\left[6 '-\left(2^{\prime \prime}, 2^{\prime \prime}-\right.\right.$ Dimethyl-[1',3']-dioxolan-4"'-yl)-7-methyl-3-oxo-1,4,5,7a-} tetrahydroisobenzofuran-3a-yl]propionitrile (76). To a solution of $75(57 \mathrm{mg}, 0.19 \mathrm{mmol})$ in EtOAc $(1.9 \mathrm{~mL})$ at $0{ }^{\circ} \mathrm{C}$ was added $\mathrm{Pd} / \mathrm{C}(30 \mathrm{mg}, 10 \%)$. The mixture was stirred for $12 \mathrm{~h}$ at $0{ }^{\circ} \mathrm{C}$ under a $\mathrm{H}_{2}$ atmosphere. After filtration, the filtrate was concentrated under vacuum and the residue was purified by chromatography (hexane-EtOAc, $3: 1)$ to give $46 \mathrm{mg}(80 \%)$ of $\mathbf{7 6}:[\alpha]_{\mathrm{D}}^{23}$ +29.2 (c 0.24, $\left.\mathrm{CHCl}_{3}\right)$; IR (neat) 2928, 2248, 1766, 1453, 1371, 1260, 1212, 1156, 1056, 1028, 
859, $799 \mathrm{~cm}^{-1} ;{ }^{1} \mathrm{H}$ NMR (400 MHz, $\left.\mathrm{CDCl}_{3}\right) \delta 1.43(\mathrm{~s}, 3 \mathrm{H}), 1.49(\mathrm{~s}, 3 \mathrm{H}), 1.75(\mathrm{~s}, 3 \mathrm{H}), 1.69-1.79$ $(\mathrm{m}, 2 \mathrm{H}), 2.11-2.34(\mathrm{~m}, 3 \mathrm{H}), 2.49(\mathrm{~m}, 2 \mathrm{H}), 3.16(\mathrm{~m}, 1 \mathrm{H}), 3.59(\mathrm{t}, J=8.0 \mathrm{~Hz}, 1 \mathrm{H}), 4.07(\mathrm{dd}, J=$ 6.9, $8.0 \mathrm{~Hz}, 1 \mathrm{H}), 4.25(\mathrm{dd}, J=8.7,12.1 \mathrm{~Hz}, 1 \mathrm{H}), 4.46(\mathrm{t}, J=7.8 \mathrm{~Hz}, 1 \mathrm{H}), 5.05(\mathrm{t}, J=7.2 \mathrm{~Hz}$, 1H); ${ }^{13} \mathrm{C}$ NMR (100Mz, $\left.\mathrm{CDCl}_{3}\right) \delta$ 12.7, 15.2, 21.8, 22.2, 25.3, 25.8, 26.7, 44.0, 49.1, 67.8, 68.1, 74.0, 109.8, 119.5, 126.0, 130.3, 178.1; HRMS (FAB) $\mathrm{m} / z 305.1620\left([\mathrm{M}]^{+}\right.$; calcd for $\mathrm{C}_{17} \mathrm{H}_{23} \mathrm{O}_{4} \mathrm{~N}$ : 305.1627).

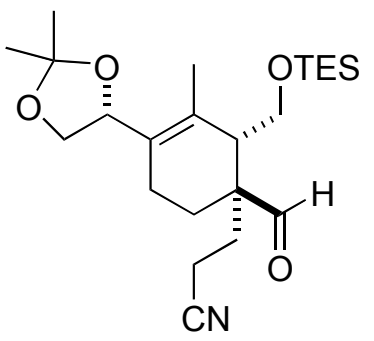

79

\section{$(3 R, 2 ' S, 4 " R)-3-[1 '-F o r m y l-4$ '-(2",2"'-dimethyl-[1",3"']-dioxolan-4' '-yl)-3'-methyl-2'-}

triethylsilanyloxymethylcyclohex-3'-enyl]propionitrile (79). To a solution of lactone 76 (35.3 $\mathrm{mg}, 0.12 \mathrm{mmol})$ in $\mathrm{Et}_{2} \mathrm{O}(1.2 \mathrm{~mL})$ at $-78{ }^{\circ} \mathrm{C}$ was added DIBAL-H $(0.14 \mathrm{~mL}$ of a $1 \mathrm{M}$ solution in toluene, $0.14 \mathrm{mmol}$ ) dropwise. The mixture was stirred for $10 \mathrm{~min}$ and a second portion of DIBAL-H $(50 \mu \mathrm{L}$ of a $1 \mathrm{M}$ solution in toluene, $0.05 \mathrm{mmol})$ was added slowly. After $10 \mathrm{~min}$, the reaction was quenched by addition of a saturated solution of Rochelle's salt and the mixture was diluted with EtOAc. The mixture was warmed to room temperature and stirred for $8 \mathrm{~h}$. The two phases were separated, and the aqueous layer was extracted with EtOAc. The combined organic extract was washed with brine, dried over $\mathrm{Na}_{2} \mathrm{SO}_{4}$, and concentrated. Flash chromatography (hexane-EtOAc, 2:1) of the residue yielded $21.2 \mathrm{mg}(60 \%)$ of a mixture of lactol 77 and aldehyde $\mathbf{7 8 .}$ 
To a solution of the mixture of 77 and $78(21.2 \mathrm{mg}, 0.069 \mathrm{mmol})$ in $\mathrm{CH}_{2} \mathrm{Cl}_{2}(1 \mathrm{~mL})$ at $0{ }^{\circ} \mathrm{C}$ was added imidazole $(14.0 \mathrm{mg}, 0.21 \mathrm{mml})$, DMAP $(2 \mathrm{mg})$, and TESCl $(29 \mu \mathrm{L}, 0.17 \mathrm{mmol})$. The mixture was stirred for $20 \mathrm{~min}$ at room temperature and the reaction was quenched by addition of a saturated solution of $\mathrm{NH}_{4} \mathrm{Cl}$. The aqueous layer was extracted with $\mathrm{CH}_{2} \mathrm{Cl}_{2}$, and the combined organic extract was washed with brine, dried over $\mathrm{Na}_{2} \mathrm{SO}_{4}$, and concentrated. Flash chromatography (hexane-EtOAc, $4: 1)$ of the residue yielded $21.8 \mathrm{mg}(75 \%)$ of 79: $[\alpha]_{\mathrm{D}}^{23}+30.6(\mathrm{c}$ 0.34, $\mathrm{CHCl}_{3}$ ); IR (neat) 2955, 2934, 2876, 2252, 1726, 1456, 1379, 1260, 1159, 1059, 1016, 860, 804, $750 \mathrm{~cm}^{-1} ;{ }^{1} \mathrm{H} \mathrm{NMR}\left(400 \mathrm{MHz}, \mathrm{CDCl}_{3}\right) \delta 0.65$ (q, $\left.J=7.9 \mathrm{~Hz}, 6 \mathrm{H}\right), 1.01(\mathrm{t}, J=7.7 \mathrm{~Hz}, 9 \mathrm{H})$, $1.39(\mathrm{~s}, 3 \mathrm{H}), 1.44(\mathrm{~s}, 3 \mathrm{H}), 1.74(\mathrm{~m}, 1 \mathrm{H}), 1.82(\mathrm{~s}, 3 \mathrm{H}), 1.85-2.02(\mathrm{~m}, 3 \mathrm{H}), 2.14(\mathrm{~m}, 2 \mathrm{H}), 2.31(\mathrm{~m}$, $1 \mathrm{H}), 2.50(\mathrm{~d}, J=7.8 \mathrm{~Hz}, 1 \mathrm{H}), 2.72(\mathrm{~m}, 1 \mathrm{H}), 3.41(\mathrm{t}, J=8.1 \mathrm{~Hz}, 1 \mathrm{H}), 3.61(\mathrm{dd}, J=8.4,11.1 \mathrm{~Hz}$, 1H), $3.69(\mathrm{dd}, J=2.7,11.4 \mathrm{~Hz}, 1 \mathrm{H}), 4.00(\mathrm{t}, J=8.0 \mathrm{~Hz}, 1 \mathrm{H}), 4.97(\mathrm{t}, J=7.3 \mathrm{~Hz}, 1 \mathrm{H}), 9.38(\mathrm{~s}$, $1 \mathrm{H}) ;{ }^{13} \mathrm{C}$ NMR $\left(100 \mathrm{Mz}, \mathrm{CDCl}_{3}\right) \delta 4.6,7.2,13.0,19.1,20.6,25.5,25.9,26.7,29.8,46.5,51.2$, 61.9, 67.4, 75.0, 109.5, 120.1, 129.4, 130.5, 204.4; HRMS (CI) $m / z$ 422.2731([M+H] $]^{+}$; calcd for $\mathrm{C}_{23} \mathrm{H}_{40} \mathrm{NO}_{4} \mathrm{Si}:$ 422.2727).

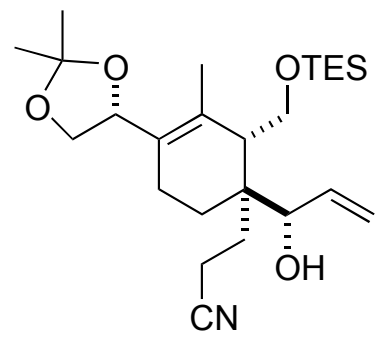

80

$(3 R, 2 ' S, 4$ ' $R)-3-\left[4^{\prime}-\left(2^{\prime \prime}, 2\right.\right.$ '-Dimethyl-[1',3']-dioxolan-4"'-yl)-3'-methyl-1'-hydroxyallyl-2'triethylsilanyloxymethylcyclohex-3'-enyl]propionitrile (80). To a solution of aldehyde 79 (77.2 $\mathrm{mg}, 0.18 \mathrm{mmol})$ in $\mathrm{THF}(2 \mathrm{~mL})$ at $-78{ }^{\circ} \mathrm{C}$ was added vinyllithium $(0.3 \mathrm{~mL}$ of a $0.92 \mathrm{M}$ solution in $\mathrm{Et}_{2} \mathrm{O}, 0.28 \mathrm{mmol}$ ) dropwise. The mixture was stirred for $1 \mathrm{~h}$ at $-78{ }^{\circ} \mathrm{C}$ and the reaction 
was quenched by addition of a saturated solution of $\mathrm{NH}_{4} \mathrm{Cl}$. After warming to room temperature, the mixture was extracted with EtOAc. The combined organic extract was washed with brine, dried over $\mathrm{Na}_{2} \mathrm{SO}_{4}$, and concentrated. Flash chromatography (hexane-EtOAc, 4:1) of the residue afforded $60.0 \mathrm{mg}(73 \%)$ of a mixture (4:1) of diastereomeric allylic alcohols. Major isomer $\mathbf{8 0}$ : $[\alpha]_{\mathrm{D}}^{23}+7.14\left(\mathrm{c} 0.21, \mathrm{CHCl}_{3}\right) ;$ IR (neat) 3472, 2954, 2933, 2876, 2248, 1456, 1417, 1379, 1242, 1157, 1062, 1005, 924, 861, 809, 746cm ${ }^{-1} ;{ }^{1} \mathrm{H}$ NMR $\left(400 \mathrm{MHz}, \mathrm{CDCl}_{3}\right) \delta 0.65$ (q, $J=7.8 \mathrm{~Hz}$ 6H), $1.00(\mathrm{t}, J=7.9 \mathrm{~Hz}, 9 \mathrm{H}), 1.41(\mathrm{~s}, 3 \mathrm{H}), 1.47(\mathrm{~s}, 3 \mathrm{H}), 1.54(\mathrm{~m}, 1 \mathrm{H}), 1.71(\mathrm{~s}, 3 \mathrm{H}), 1.78(\mathrm{~m}, 1 \mathrm{H})$, $1.84(\mathrm{~m}, 1 \mathrm{H}), 1.93-2.15(\mathrm{~m}, 3 \mathrm{H}), 2.25(\mathrm{~d}, J=8.4 \mathrm{~Hz}, 1 \mathrm{H}), 2.46(\mathrm{ddd}, J=5.0,11.8,16.7 \mathrm{~Hz}$ 1H), $2.63(\mathrm{ddd}, J=5.0,11.8,16.7 \mathrm{~Hz}, 1 \mathrm{H}), 2.84(\mathrm{~d}, J=5.9 \mathrm{~Hz}, 1 \mathrm{H}), 3.50-3.59(\mathrm{~m}, 2 \mathrm{H}), 3.71$ $(\mathrm{dd}, J=2.7,11.3 \mathrm{~Hz}, 1 \mathrm{H}), 3.91(\mathrm{t}, J=6.1 \mathrm{~Hz}, 1 \mathrm{H}), 4.08(\mathrm{dd}, J=6.7,7.8 \mathrm{~Hz}, 1 \mathrm{H}), 4.98(\mathrm{t}, J=7.1$ $\mathrm{Hz}, 1 \mathrm{H}), 5.22(\mathrm{~d}, J=18.4 \mathrm{~Hz}, 1 \mathrm{H}), 5.25(\mathrm{~d}, J=11.4 \mathrm{~Hz}, 1 \mathrm{H}), 5.95(\mathrm{ddd}, J=6.3,10.5,16.9 \mathrm{~Hz}$ $1 \mathrm{H}) ;{ }^{13} \mathrm{C}$ NMR (100Mz, $\left.\mathrm{CDCl}_{3}\right) \delta$ 4.6, 7.2, 12.9, 19.0, 20.6, 25.8, 26.0, 26.8, 28.4, 41.7, 49.4, 62.0, 67.4, 75.5, 75.9, 109.5, 117.5, 121.4, 128.8, 130.7, 138.0; HRMS (CI) $\mathrm{m} / \mathrm{z}\left([\mathrm{M}+\mathrm{H}]^{+}\right.$: 450.3049; calcd for $\mathrm{C}_{23} \mathrm{H}_{44} \mathrm{NO}_{4} \mathrm{Si}: 450.3040$ ).

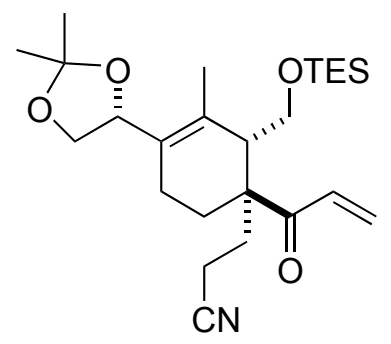

81

\section{$\left(3 R, 2^{\prime} S, 4 " R\right)-3-[1 '-A c r y l o y l-4 '-(2 ", 2$ '-dimethyl-[1",3']-dioxolan-4"'-yl)-3'-methyl-2'-}

triethylsilanyloxymethylcyclohex-3'-enyl]propionitrile (81). To a solution of oxalyl chloride (5 $\mu \mathrm{l}, 0.040 \mathrm{mmol})$ in $\mathrm{CH}_{2} \mathrm{Cl}_{2}(0.5 \mathrm{~mL})$ at $-78{ }^{\circ} \mathrm{C}$ was added a solution of DMSO (10 $\mu \mathrm{L}, 0.10$ $\mathrm{mmol})$ in $\mathrm{CH}_{2} \mathrm{Cl}_{2}(0.3 \mathrm{~mL})$. The mixture was stirred for $5 \mathrm{~min}$, and a solution of alcohol $\mathbf{8 0}$ (9.0 
$\mathrm{mg}, 0.020 \mathrm{mmol})$ in $\mathrm{CH}_{2} \mathrm{Cl}_{2}(0.3 \mathrm{~mL})$ was added. The mixture was stirred for $10 \mathrm{~min}$ at $-78{ }^{\circ} \mathrm{C}$, $\mathrm{Et}_{3} \mathrm{~N}(11 \mu \mathrm{L}, 0.080 \mathrm{mmol})$ was added, and the mixture was allowed to warm to room temperature. The reaction was quenched by addition of saturated aqueous $\mathrm{NaHCO}_{3}$, and the mixture was diluted with $\mathrm{CH}_{2} \mathrm{Cl}_{2}$. The phases were separated, the aqueous phase was extracted with $\mathrm{CH}_{2} \mathrm{Cl}_{2}(2 \mathrm{x})$, and the combined organic extract was washed with brine, dried over $\mathrm{Na}_{2} \mathrm{SO}_{4}$, and concentrated under vacuum. Flash chromatography (hexane-EtOAc, 4:1) of the residue afforded recovered $\mathbf{8 0}(5.4 \mathrm{mg})$ and $3.2 \mathrm{mg}(36 \%)$ of $\mathbf{8 1}:[\alpha]_{\mathrm{D}}^{23}+70.8\left(\mathrm{c} 0.13, \mathrm{CHCl}_{3}\right)$; IR (neat) 2954, 2925, 2875, 2854, 2249, 1692, 1456, 1400, 1379, 1243, 1157, 1086, 1062, 1017, 861, 812, $746 \mathrm{~cm}^{-1} ;{ }^{1} \mathrm{H}$ NMR $\left(400 \mathrm{MHz}, \mathrm{CDCl}_{3}\right) \delta 0.66(\mathrm{q}, J=7.9 \mathrm{~Hz}, 6 \mathrm{H}), 1.01(\mathrm{t}, J=7.9 \mathrm{~Hz}, 9 \mathrm{H}), 1.37$ (s, 3H), $1.42(\mathrm{~s}, 3 \mathrm{H})), 1.83(\mathrm{~s}, 3 \mathrm{H}), 1.82-2.22(\mathrm{~m}, 4 \mathrm{H}), 2.07(\mathrm{~m}, 1 \mathrm{H}), 2.27(\mathrm{~m}, 2 \mathrm{H}), 2.66(\mathrm{~m}$, 2H), $3.32(\mathrm{t}, J=8.0 \mathrm{~Hz}, 1 \mathrm{H}), 3.56-3.62(\mathrm{~m}, 2 \mathrm{H}), 3.93(\mathrm{dd}, J=6.6,8.2 \mathrm{~Hz}, 1 \mathrm{H}), 4.94(\mathrm{t}, J=7.3$ $\mathrm{Hz}, 1 \mathrm{H}), 5.75(\mathrm{dd}, J=1.8,10.3 \mathrm{~Hz}, 1 \mathrm{H}), 6.43(\mathrm{dd}, J=1.8,16.8 \mathrm{~Hz}, 1 \mathrm{H}), 6.85(\mathrm{dd}, \mathrm{J}=10.3,16.8$ $\mathrm{Hz}, 1 \mathrm{H}) ;{ }^{13} \mathrm{C} \mathrm{NMR}\left(100 \mathrm{Mz}, \mathrm{CDCl}_{3}\right) \delta 4.2,6.9,12.8,18.9,20.5,25.4,26.3,26.5,31.8,45.9,52.4$, 62.0, 66.9, 74.5, 109.0, 119.7, 128.2, 129.7, 130.2, 130.6, 200.6; HRMS (CI) $\mathrm{m} / \mathrm{z}$ found 448.2895; $\left([\mathrm{M}+\mathrm{H}]^{+}\right.$calcd for $\left.\mathrm{C}_{25} \mathrm{H}_{42} \mathrm{O}_{4} \mathrm{SiN}: 448.2883\right)$.

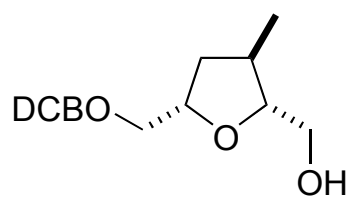

(2R,3R,5S)-5-(2,6-Dichlorobenzyloxymethyl)-3-methyltetrahydrofuran-2-ylmethanol. To a solution of ether $25(1.10 \mathrm{~g}, 2.60 \mathrm{mmol})$ in $\mathrm{THF}(30 \mathrm{~mL})$ at $0{ }^{\circ} \mathrm{C}$ was added a solution of TBAF in THF (1 M, $3.7 \mathrm{~mL})$ under argon, and the mixture was stirred for $2 \mathrm{~h}$ at room temperature. The reaction was quenched by addition of saturated aqueous $\mathrm{NH}_{4} \mathrm{Cl}$, and the mixture was diluted with EtOAc. The phases were separated and the aqueous phase was 
extracted with EtOAc $(2 \mathrm{x})$. The organic layer was washed with brine, dried over $\mathrm{Na}_{2} \mathrm{SO}_{4}$, and concentrated under vacuum. Flash chromatography (hexane-EtOAc, 2:1) of the residue gave $0.76 \mathrm{~g}(95 \%)$ of an alcohol as a colorless oil: $[\alpha]_{\mathrm{D}}^{23}-6.1$ (c $\left.0.72, \mathrm{CHCl}_{3}\right)$; IR (neat) 3443, 2956, 2924, 1872, 1582, 1564, 1456, 1437, 1379, 1198, 1102, 779, $767 \mathrm{~cm}^{-1} ;{ }^{1} \mathrm{H}$ NMR (300 MHz, $\left.\mathrm{CDCl}_{3}\right) \delta 1.05(\mathrm{~d}, J=6.7 \mathrm{~Hz}, 3 \mathrm{H}), 1.64(\mathrm{ddd}, J=7.8,12.4,15.6 \mathrm{~Hz}, 1 \mathrm{H}), 2.03(\mathrm{ddd}, J=3.6,9.8$ $\mathrm{Hz}, 1 \mathrm{H}), 3.55(\mathrm{~m}, 1 \mathrm{H}), 3.62(\mathrm{dd}, J=4.1,9.8 \mathrm{~Hz}, 1 \mathrm{H}), 3.75(\mathrm{~m}, 1 \mathrm{H}), 4.23(\mathrm{ddd}, J=4.6,9.4,12.5$ $\mathrm{Hz}, 1 \mathrm{H}), 4.80(\mathrm{~s}, 2 \mathrm{H}), 7.15-7.35(\mathrm{~m}, 3 \mathrm{H}) ;{ }^{13} \mathrm{C} \mathrm{NMR}\left(100 \mathrm{Mz}, \mathrm{CDCl}_{3}\right) \delta$ 18.1, 34.1, 37.3, 63.9, 68.0, 73.6, 77.4, 87.4, 128.8, 130.4, 135.5, 137.3; HRMS (CI) m/z $305.0713\left([\mathrm{M}]^{+}\right.$; calcd. for $\left.\mathrm{C}_{14} \mathrm{H}_{19} \mathrm{O}_{3}{ }^{35} \mathrm{Cl}_{2}: 305.0711\right)$.

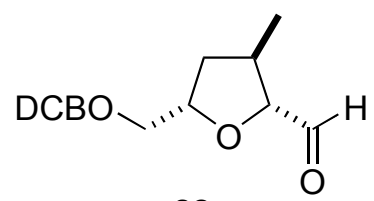

82

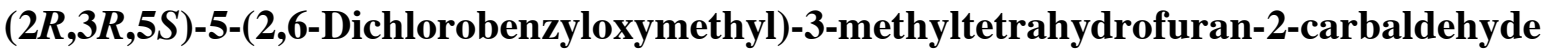

(82). To a solution of oxalyl chloride $(0.41 \mathrm{~mL}, 4.6 \mathrm{mmol})$ in $\mathrm{CH}_{2} \mathrm{Cl}_{2}(4 \mathrm{~mL})$ was added a solution of DMSO $(0.65 \mathrm{~mL}, 9.24 \mathrm{mmol})$ in $\mathrm{CH}_{2} \mathrm{Cl}_{2}(2 \mathrm{~mL})$ at $-78{ }^{\circ} \mathrm{C}$. The mixture was stirred for $5 \mathrm{~min}$, and a solution of the alcohol prepared above $(0.71 \mathrm{~g}, 2.3 \mathrm{mmol})$ in $\mathrm{CH}_{2} \mathrm{Cl}_{2}(14 \mathrm{~mL})$ was added. The mixture was stirred for $15 \mathrm{~min}$ at $-78{ }^{\circ} \mathrm{C}, \mathrm{Et}_{3} \mathrm{~N}(1.3 \mathrm{~mL}, 9.2 \mathrm{mmol})$ was added, and the resulting mixture was allowed to warm to room temperature. The reaction was quenched by addition of saturated aqueous $\mathrm{NaHCO}_{3}$, and the mixture was diluted with $\mathrm{CH}_{2} \mathrm{Cl}_{2}$. After the phases were separated, the aqueous phase was extracted with $\mathrm{CH}_{2} \mathrm{Cl}_{2}(2 \mathrm{x})$. The combined organic layer was washed with brine, dried over $\mathrm{Na}_{2} \mathrm{SO}_{4}$, and concentrated under vacuum. Flash chromatography (hexane-EtOAc, $4: 1)$ of the residue afforded $0.66 \mathrm{~g}(93 \%)$ of $82:[\alpha]_{\mathrm{D}}^{23}+22.8(\mathrm{c}$ 
$0.24, \mathrm{CHCl}_{3}$ ); IR (neat) 2958, 2923, 1852, 1731, 1461, 1436, 1277, 1101, 767, $728 \mathrm{~cm}^{-1} ;{ }^{1} \mathrm{H}$ $\operatorname{NMR}\left(300 \mathrm{MHz}, \mathrm{CDCl}_{3}\right) \delta 1.70(\mathrm{~m}, 1 \mathrm{H}), 1.95(\mathrm{~m}, 1 \mathrm{H}), 2.35(\mathrm{~m}, 1 \mathrm{H}), 3.59(\mathrm{dd}, J=1.7,4.76 \mathrm{~Hz}$, 2H), $3.75(\mathrm{dd}, J=2.5,7.5 \mathrm{~Hz}, 1 \mathrm{H}), 4.38(\mathrm{~m}, 1 \mathrm{H}), 4.82(\mathrm{~d}, J=1.8 \mathrm{~Hz}, 2 \mathrm{H}), 7.15-7.35(\mathrm{~m}, 3 \mathrm{H})$, $9.62(\mathrm{~d}, J=2.5 \mathrm{~Hz}, 1 \mathrm{H}) ;{ }^{13} \mathrm{C} \mathrm{NMR}\left(100 \mathrm{Mz}, \mathrm{CDCl}_{3}\right) \delta 17.9,36.4,36.9,68.1,73.5,79.4,90.2$, 128.8, 130.4, 133.6, 137.3, 203.6; HRMS (FAB) $\mathrm{m} / \mathrm{z} 303.0561$ ([M] $]^{+}$; calcd for $\mathrm{C}_{14} \mathrm{H}_{17} \mathrm{O}_{3}{ }^{35} \mathrm{Cl}_{2}$ : 303.0555). 


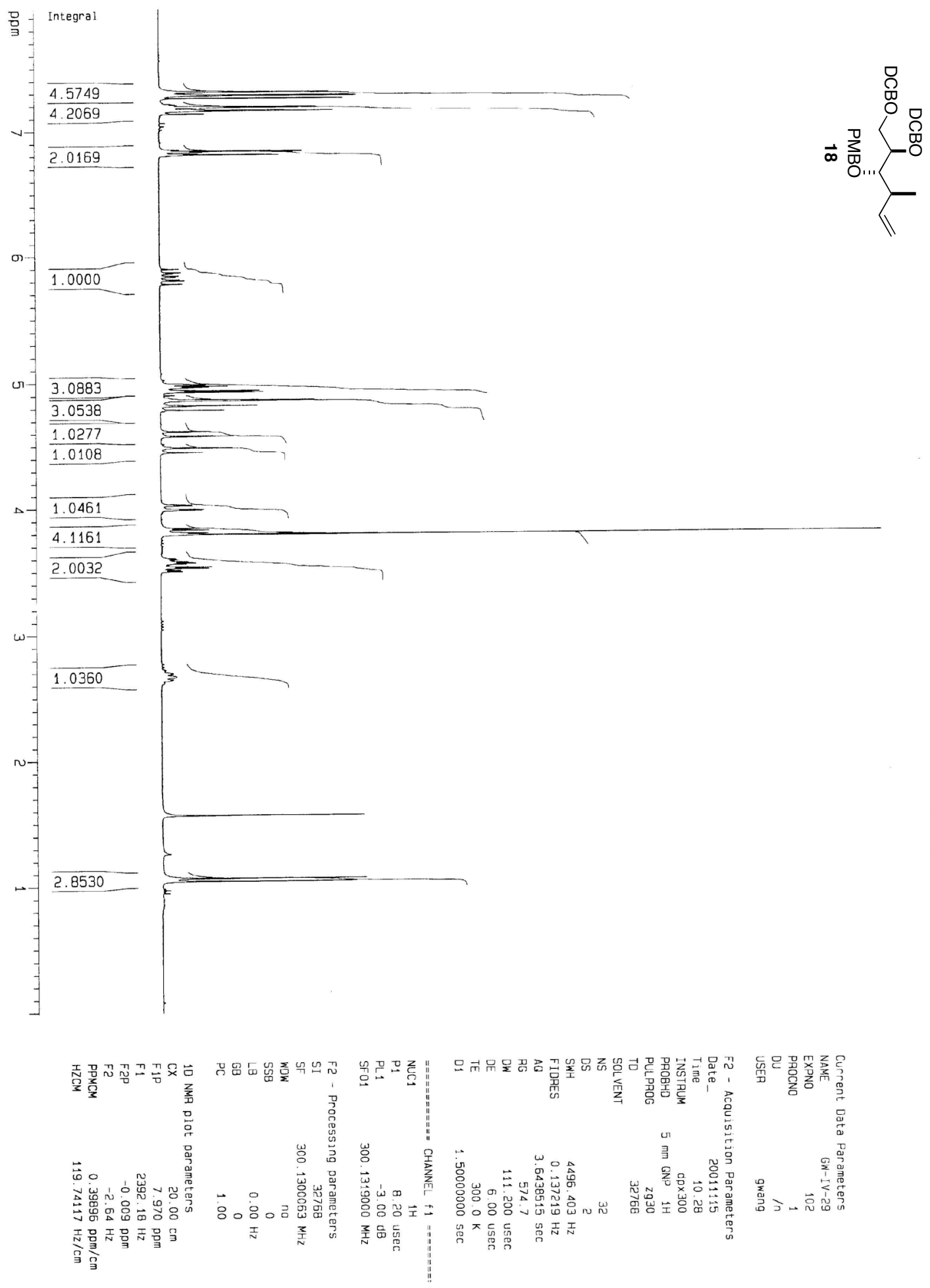




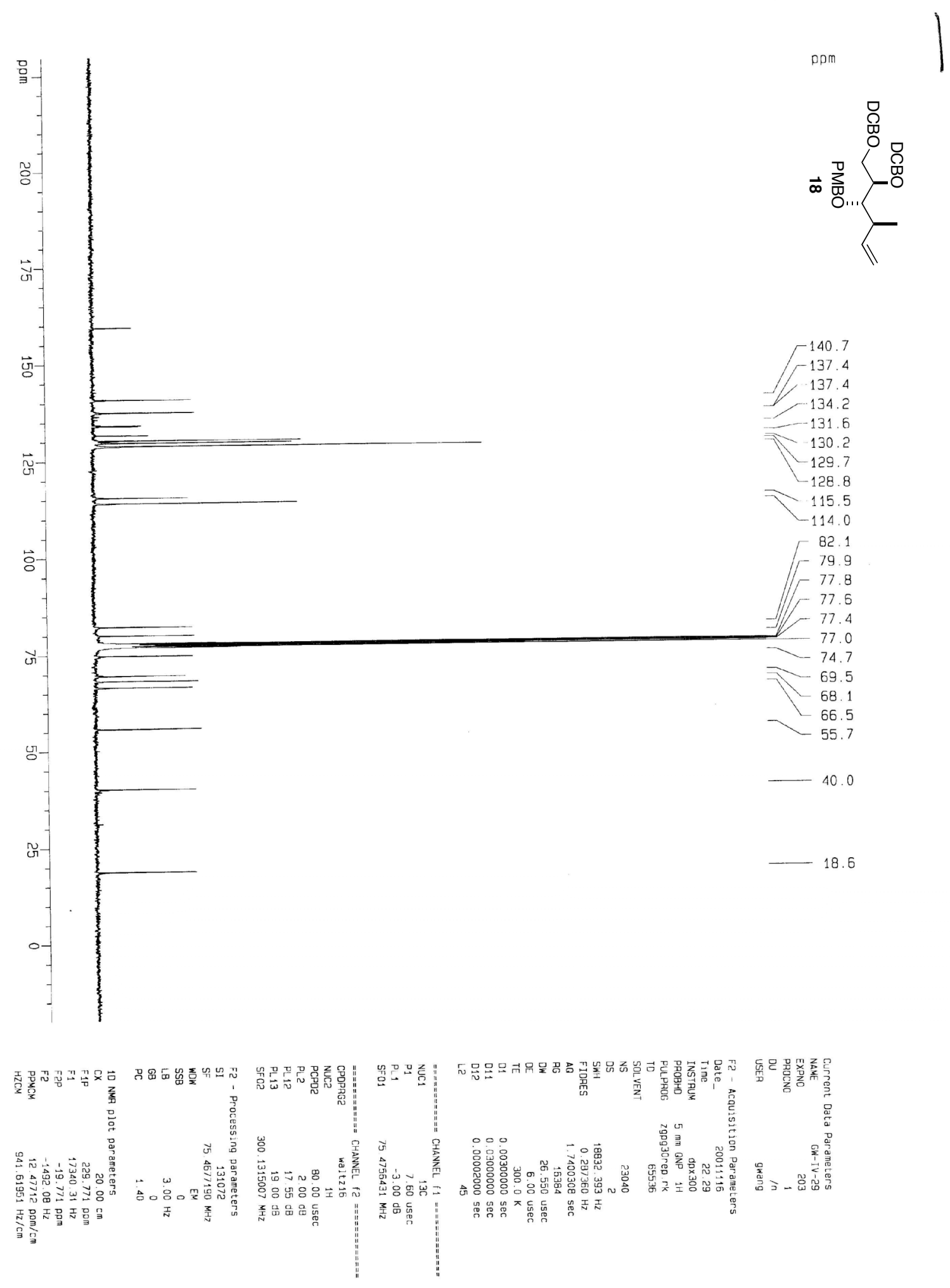




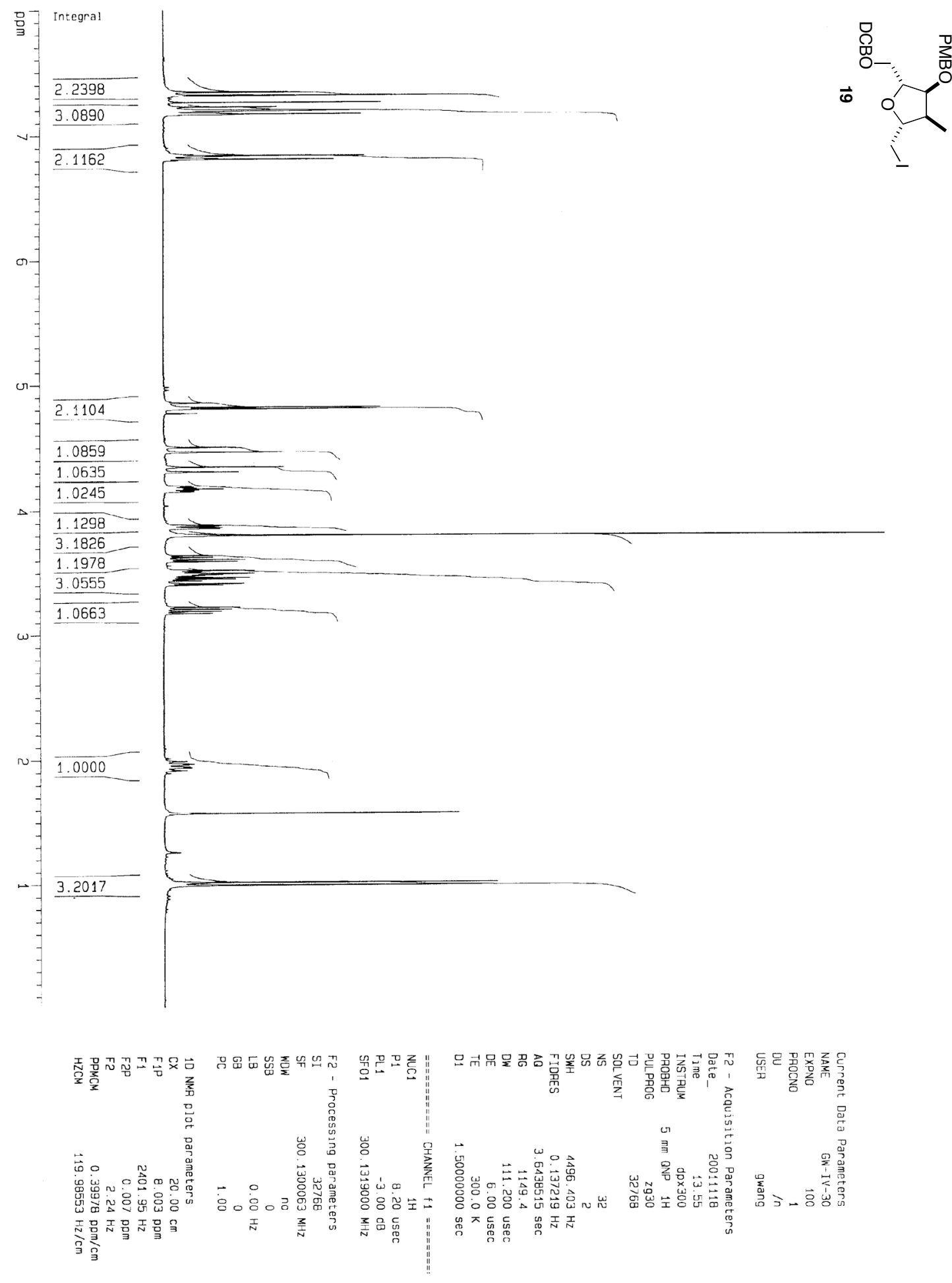



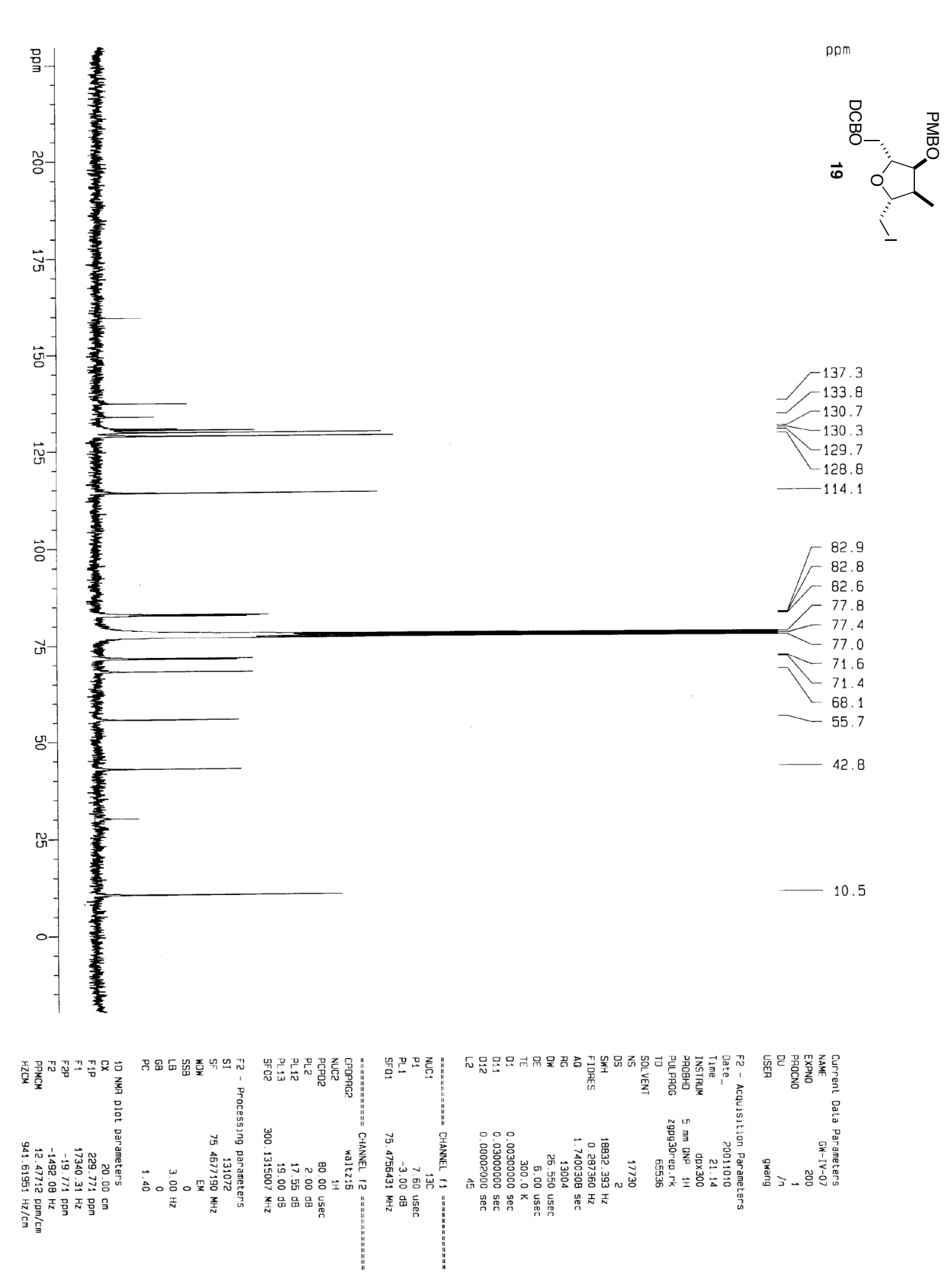


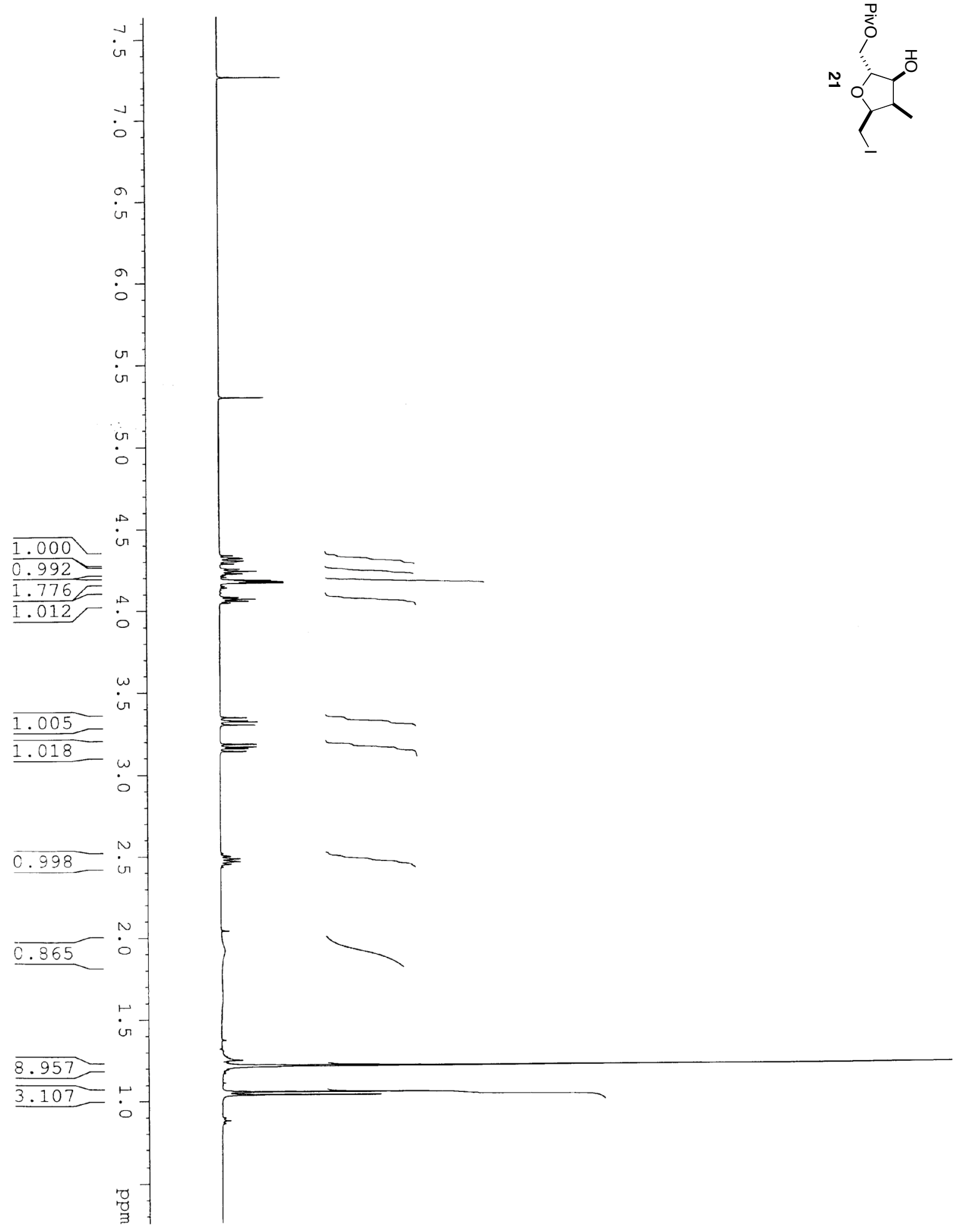




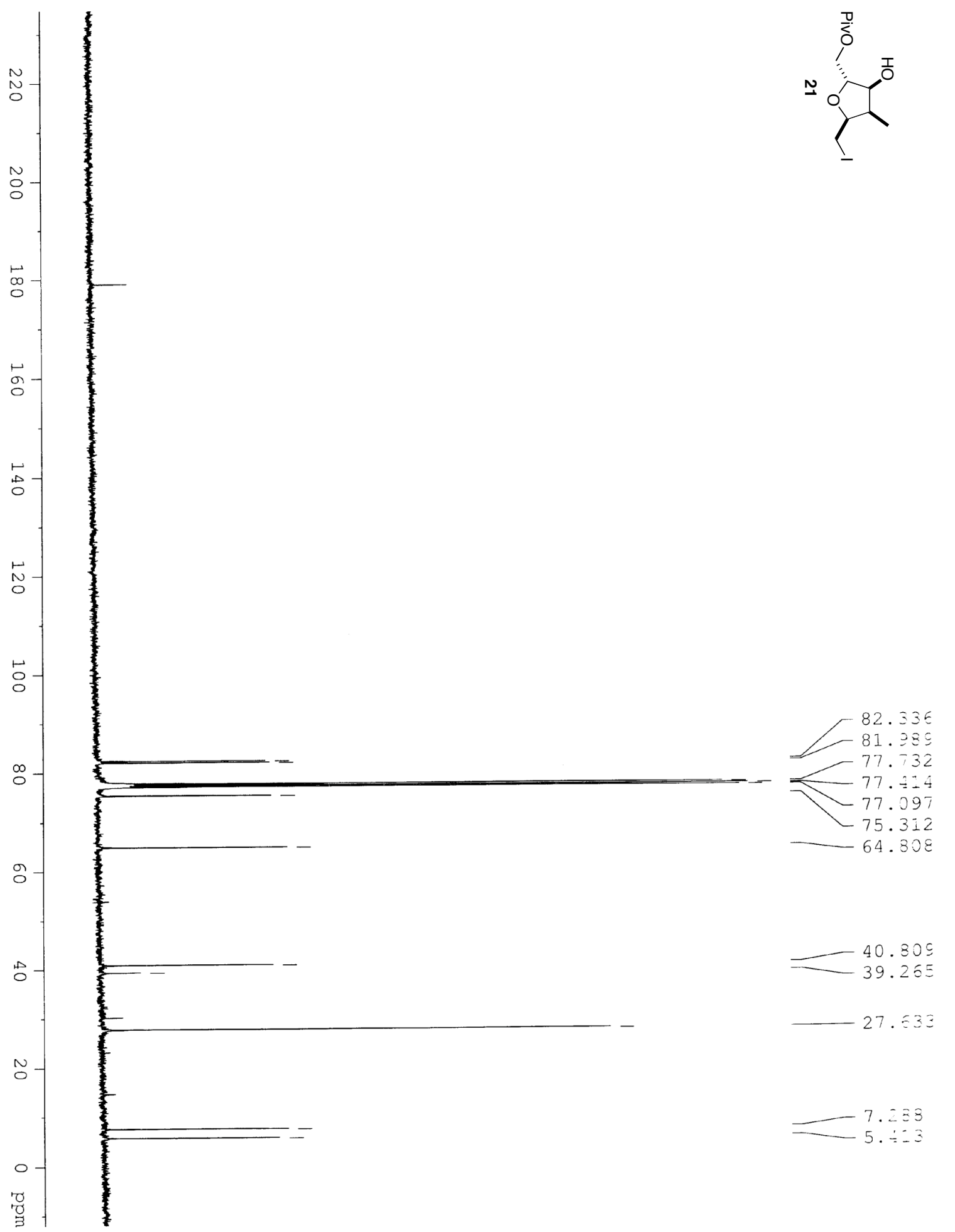




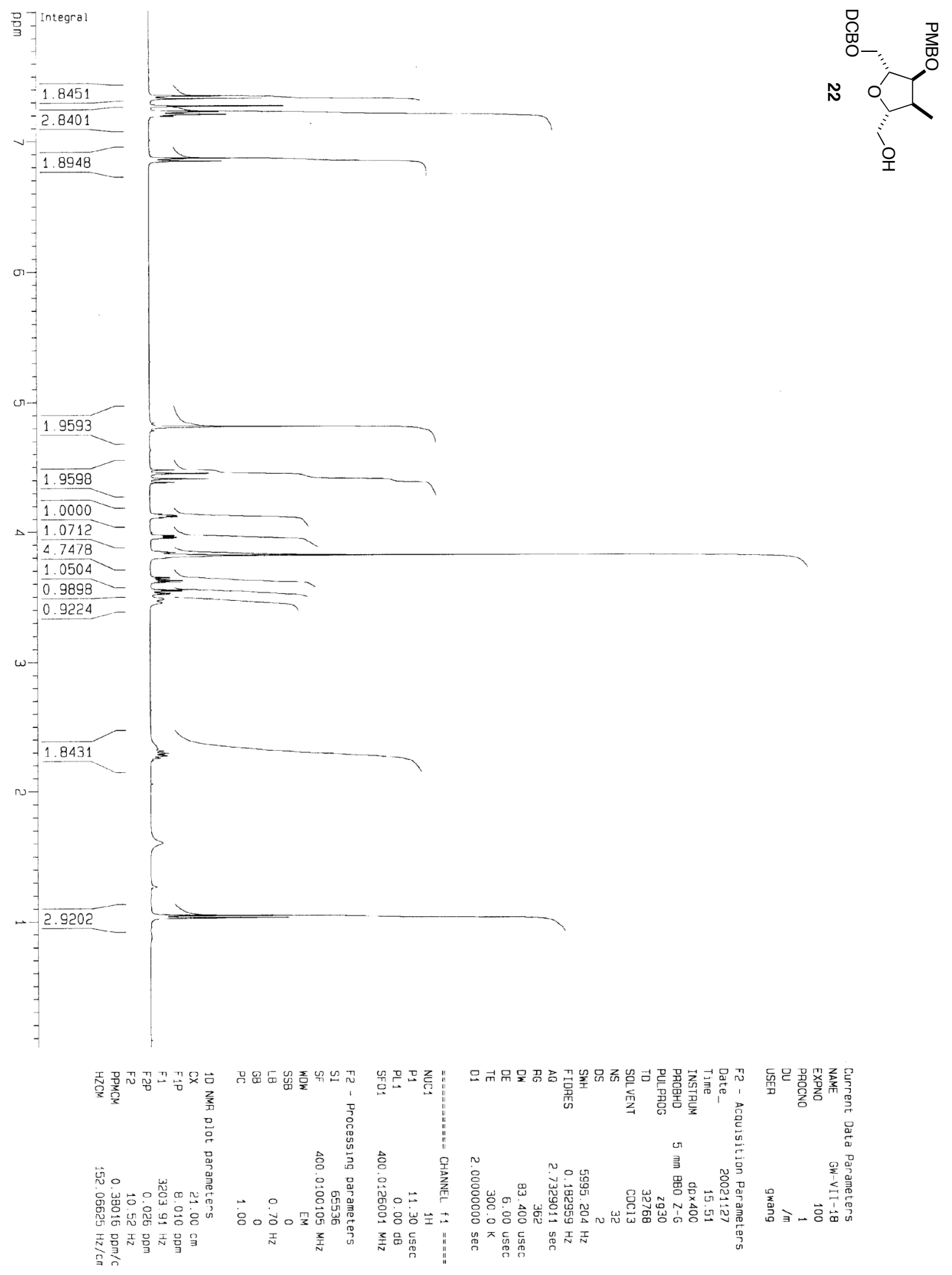



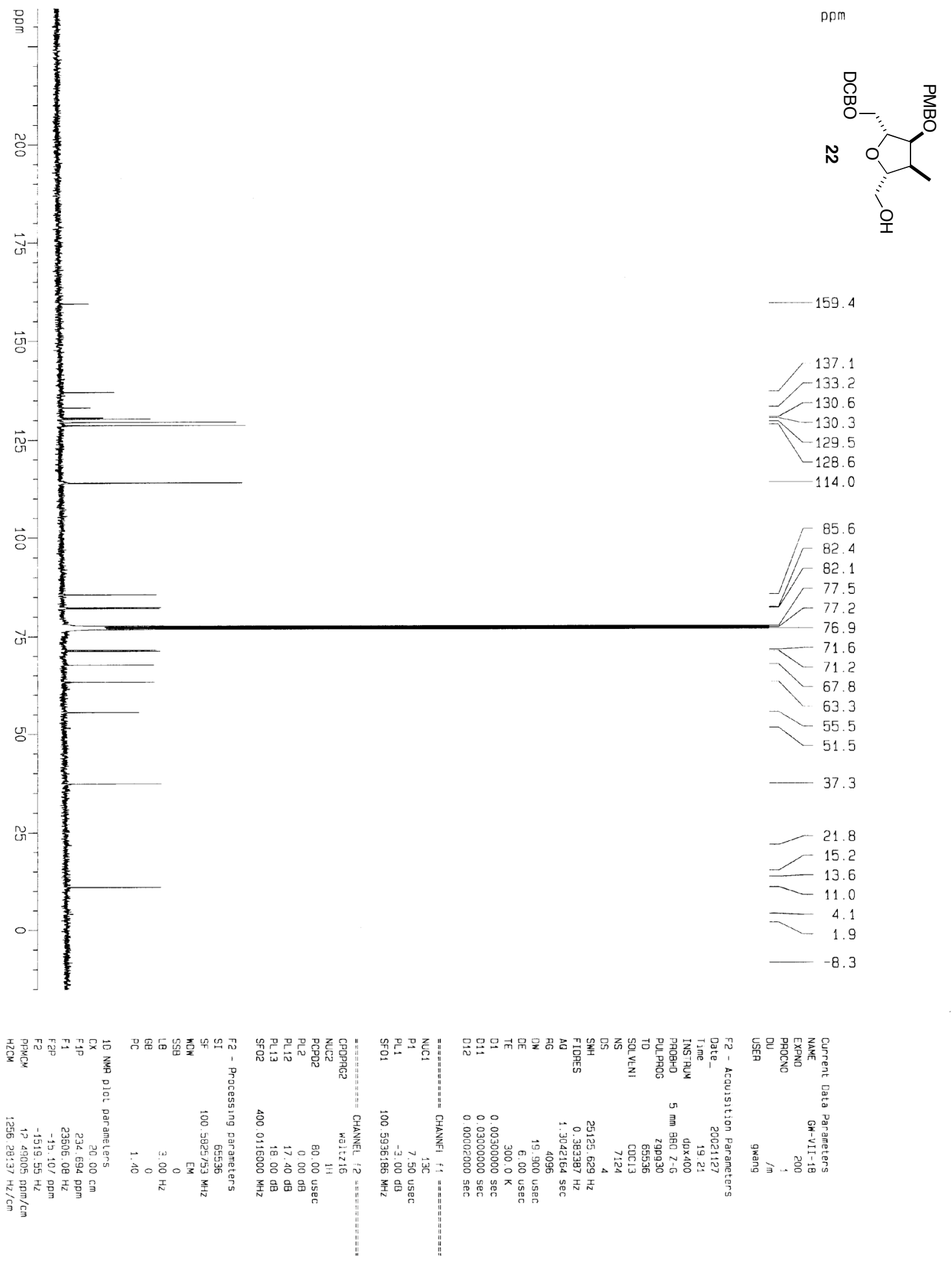


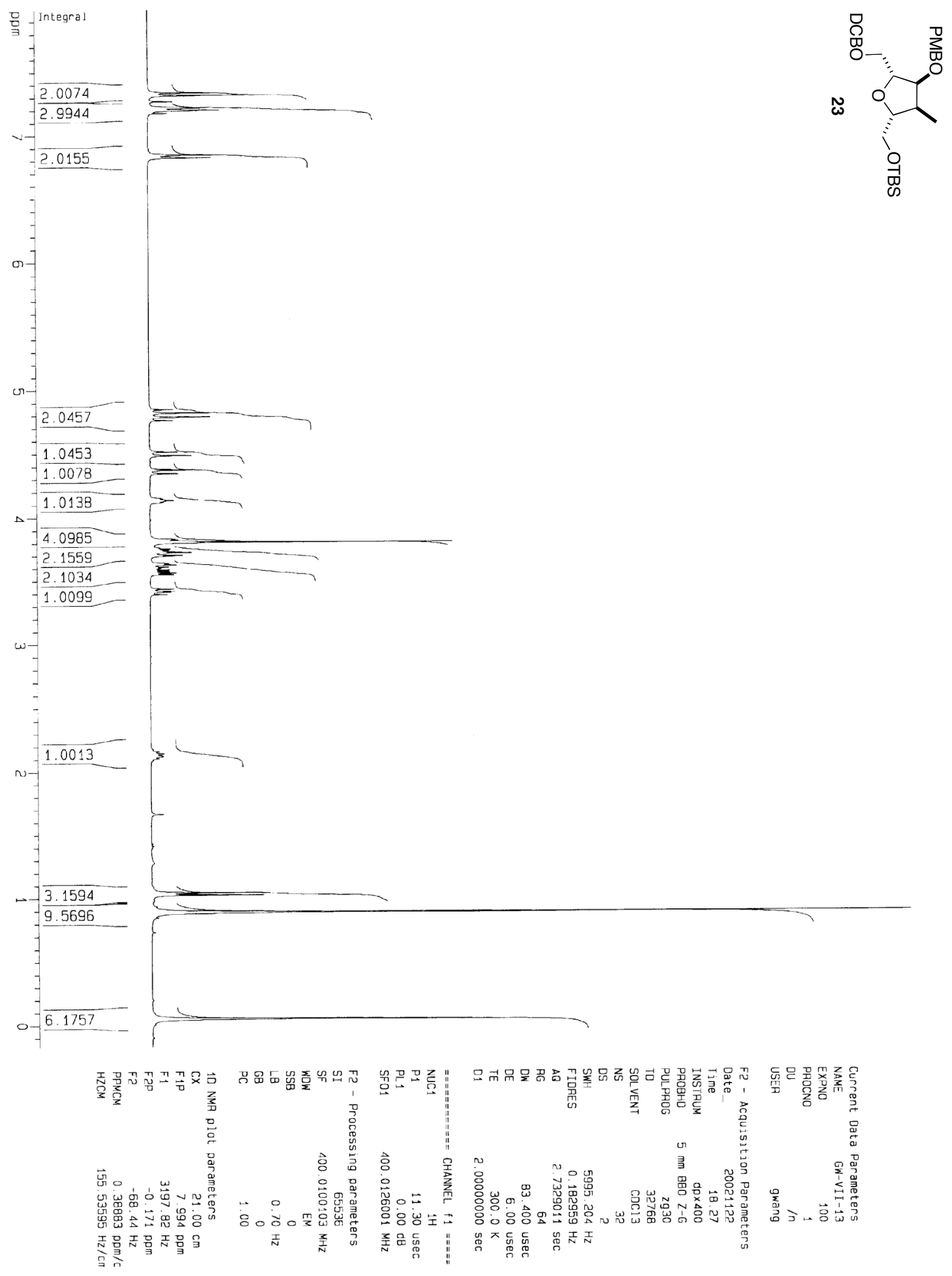



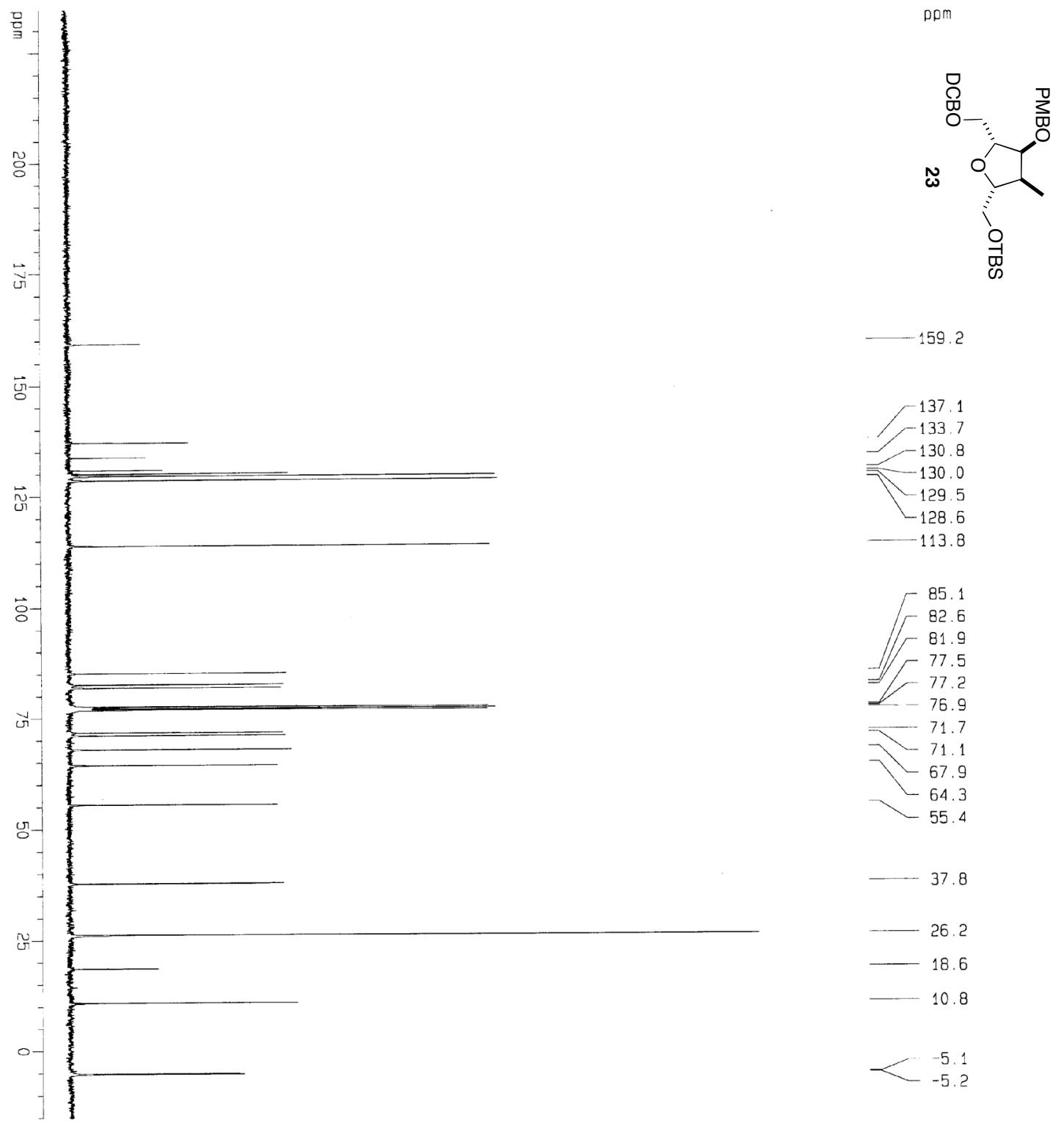

- 26.2

$-18.6$

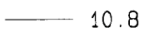

$<\begin{array}{r}-5.1 \\ -5.2\end{array}$

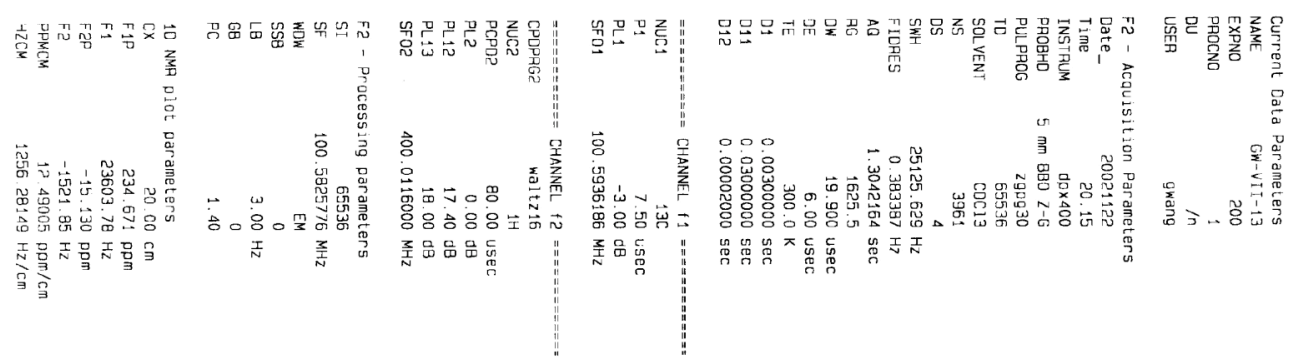




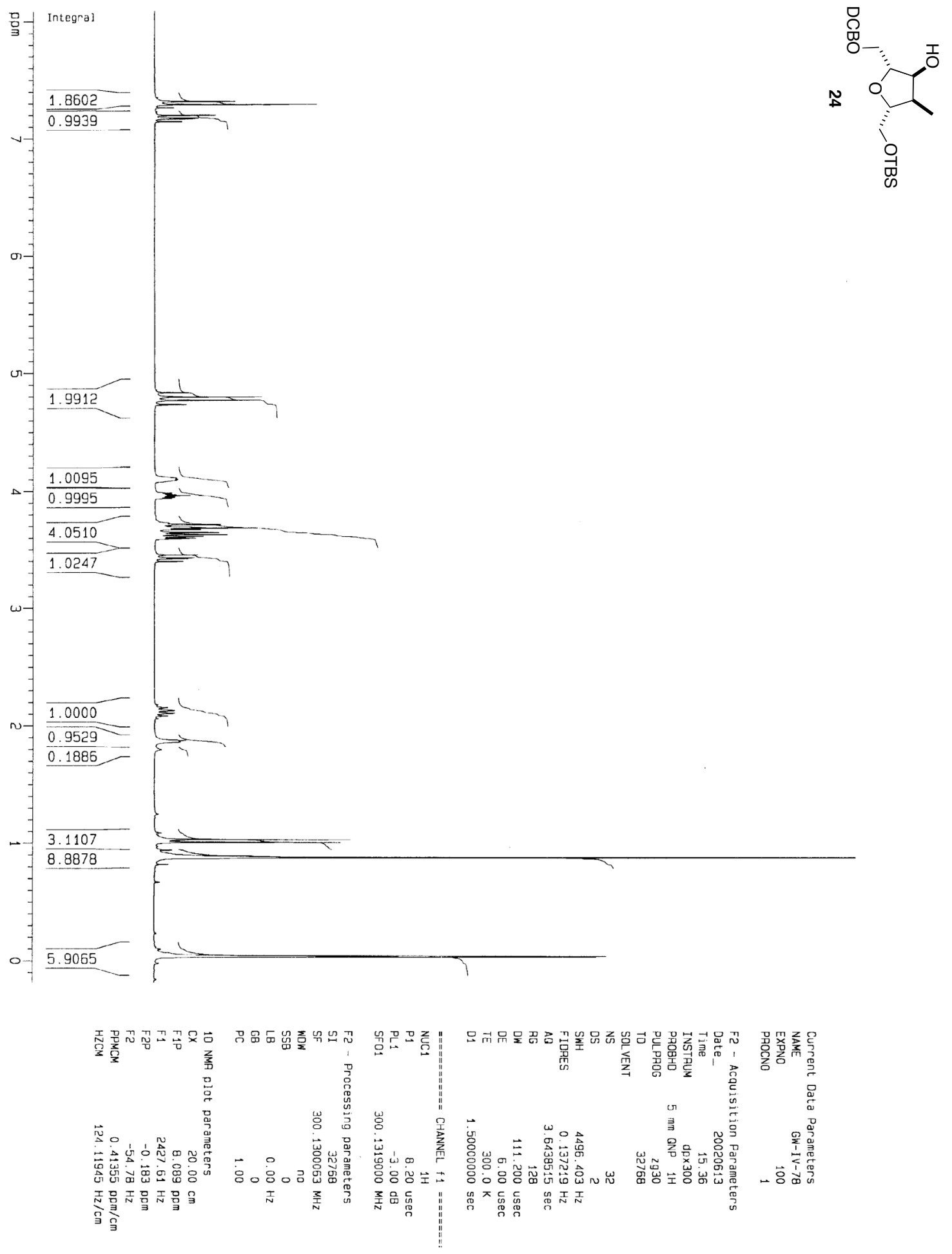




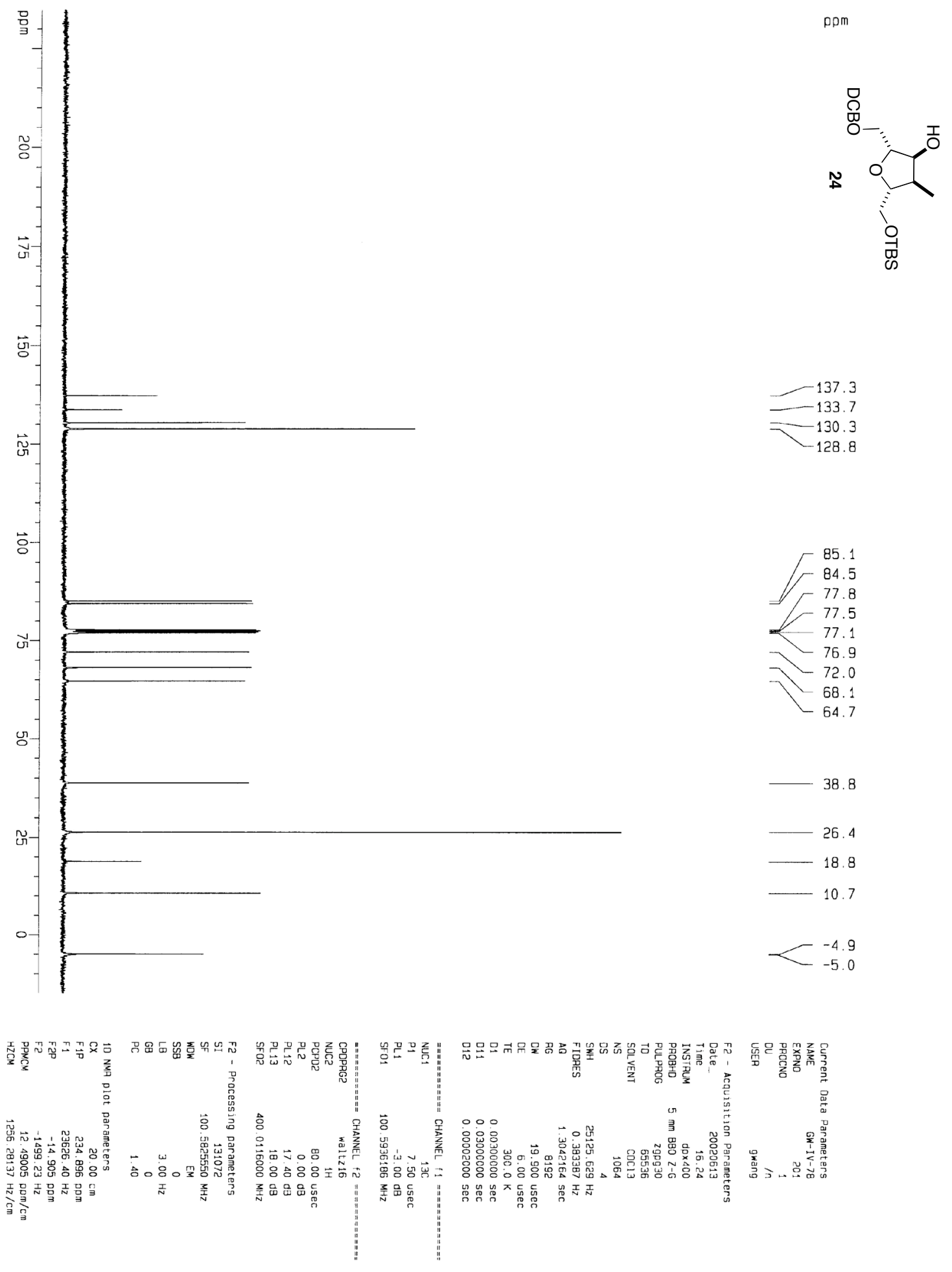




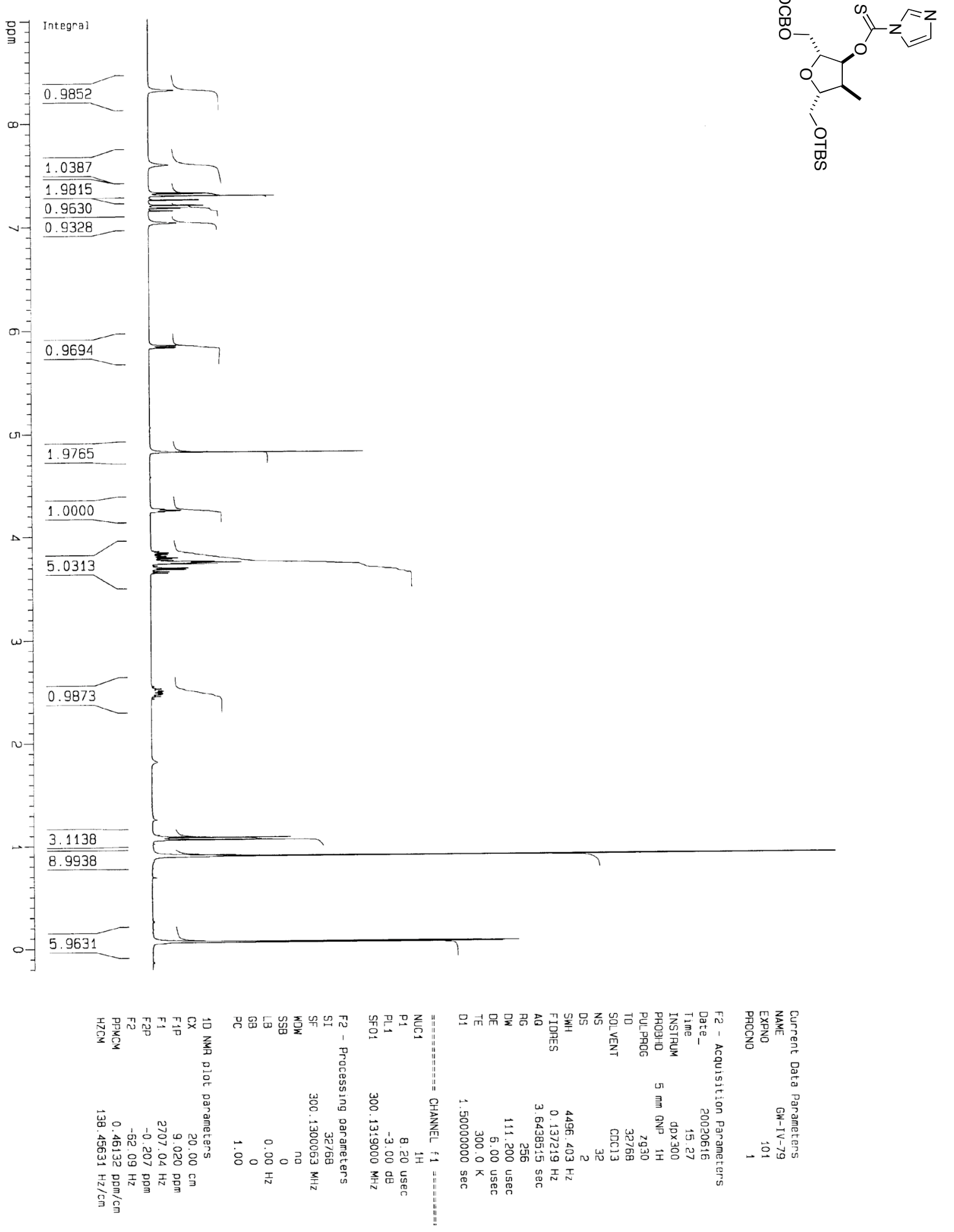




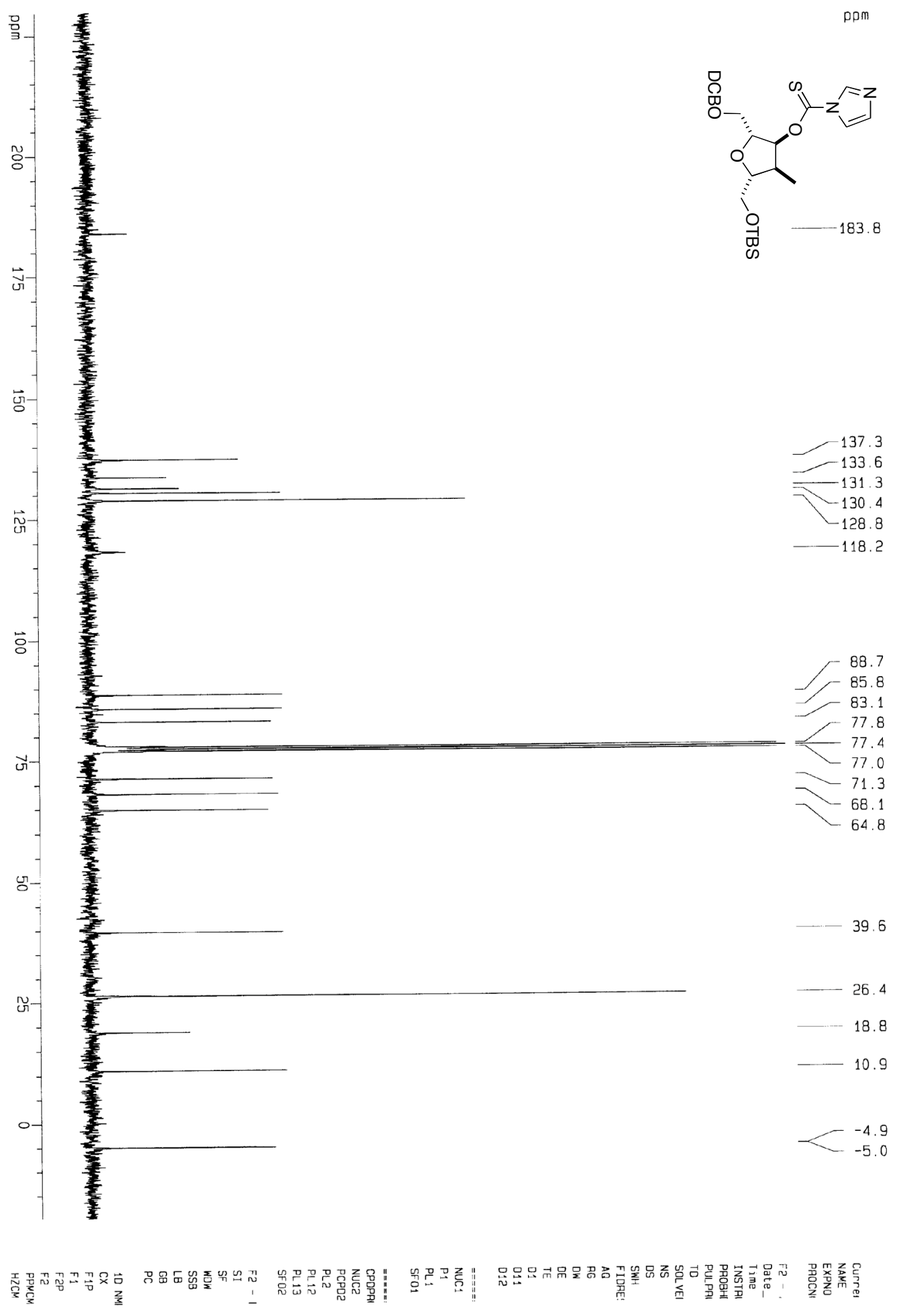




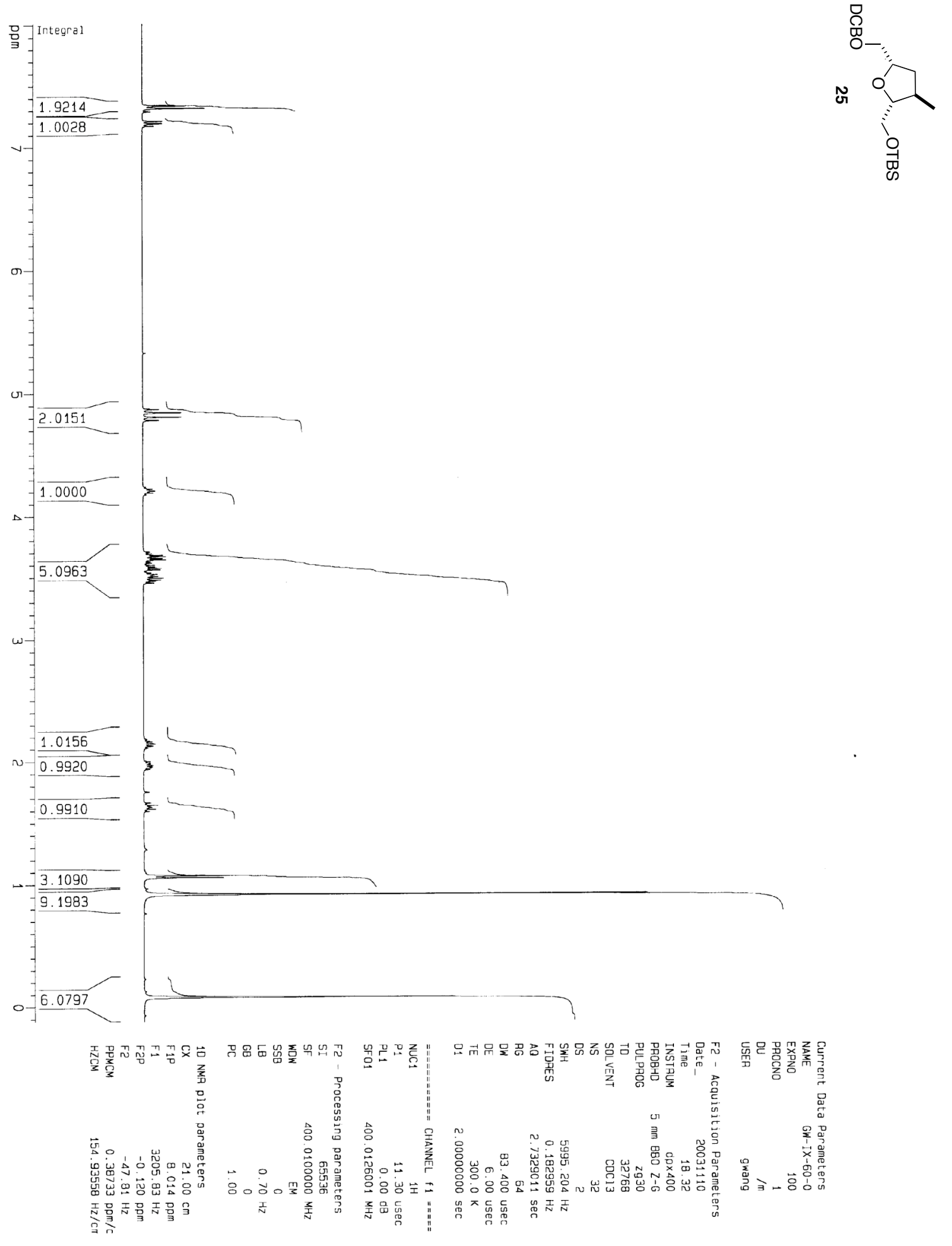



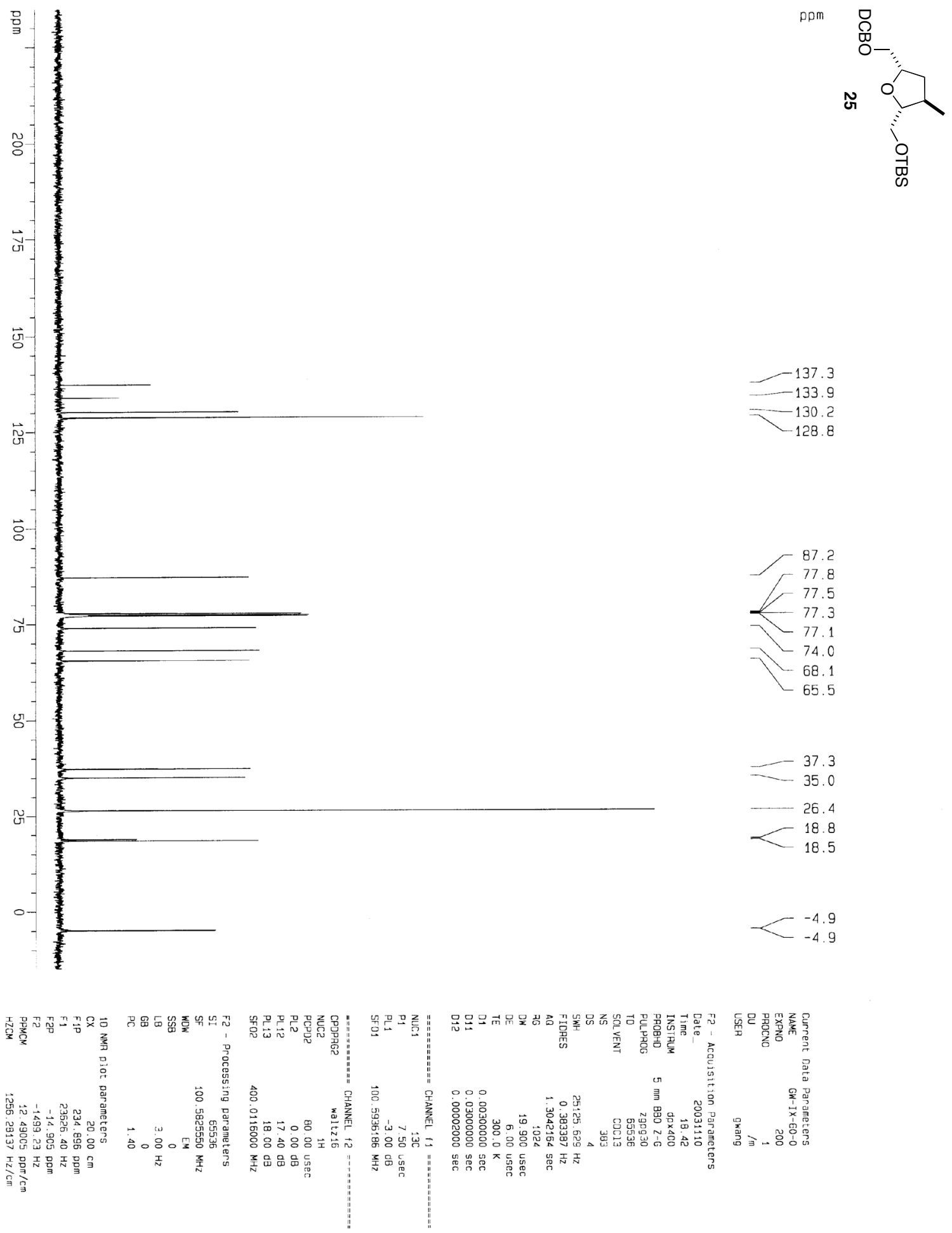


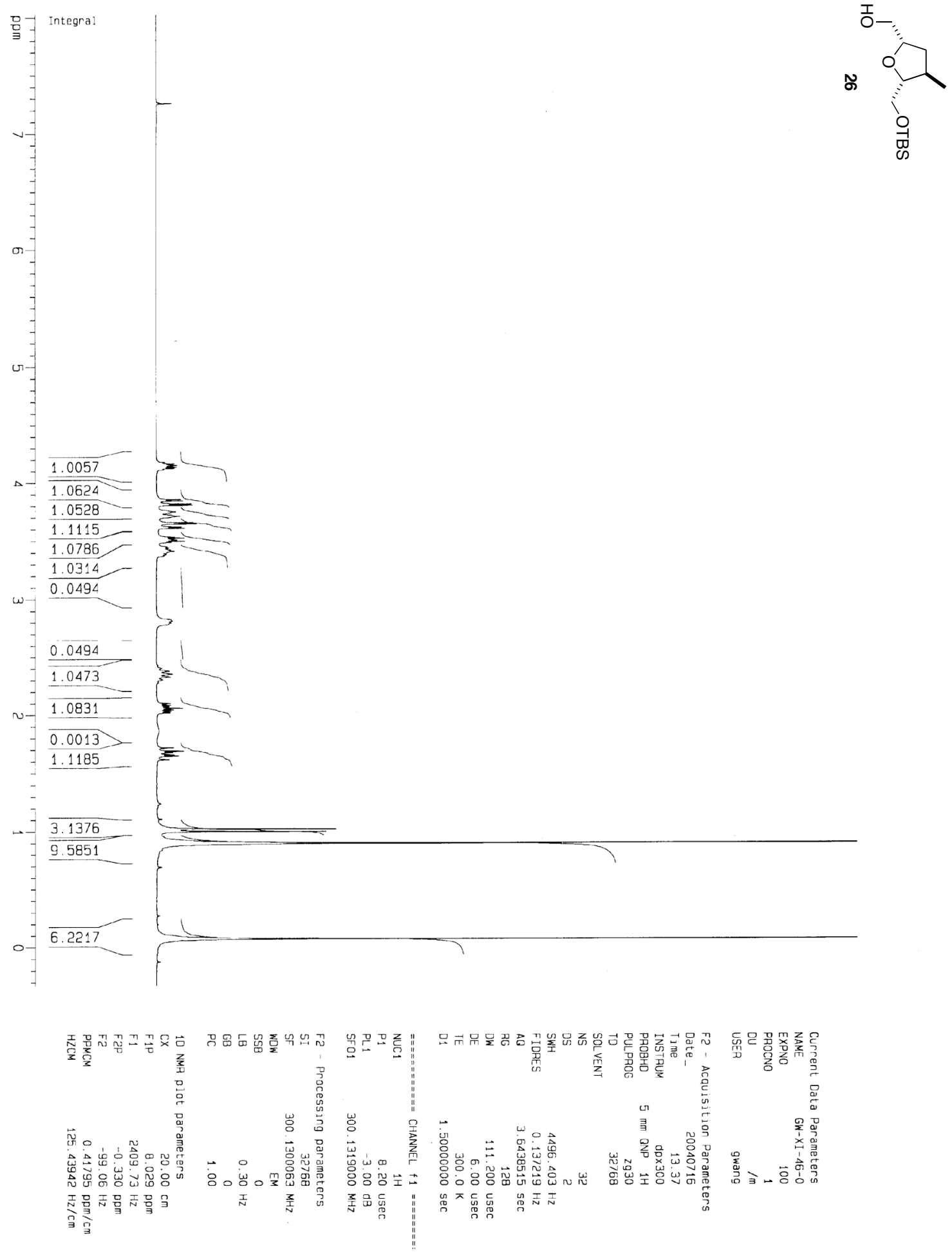



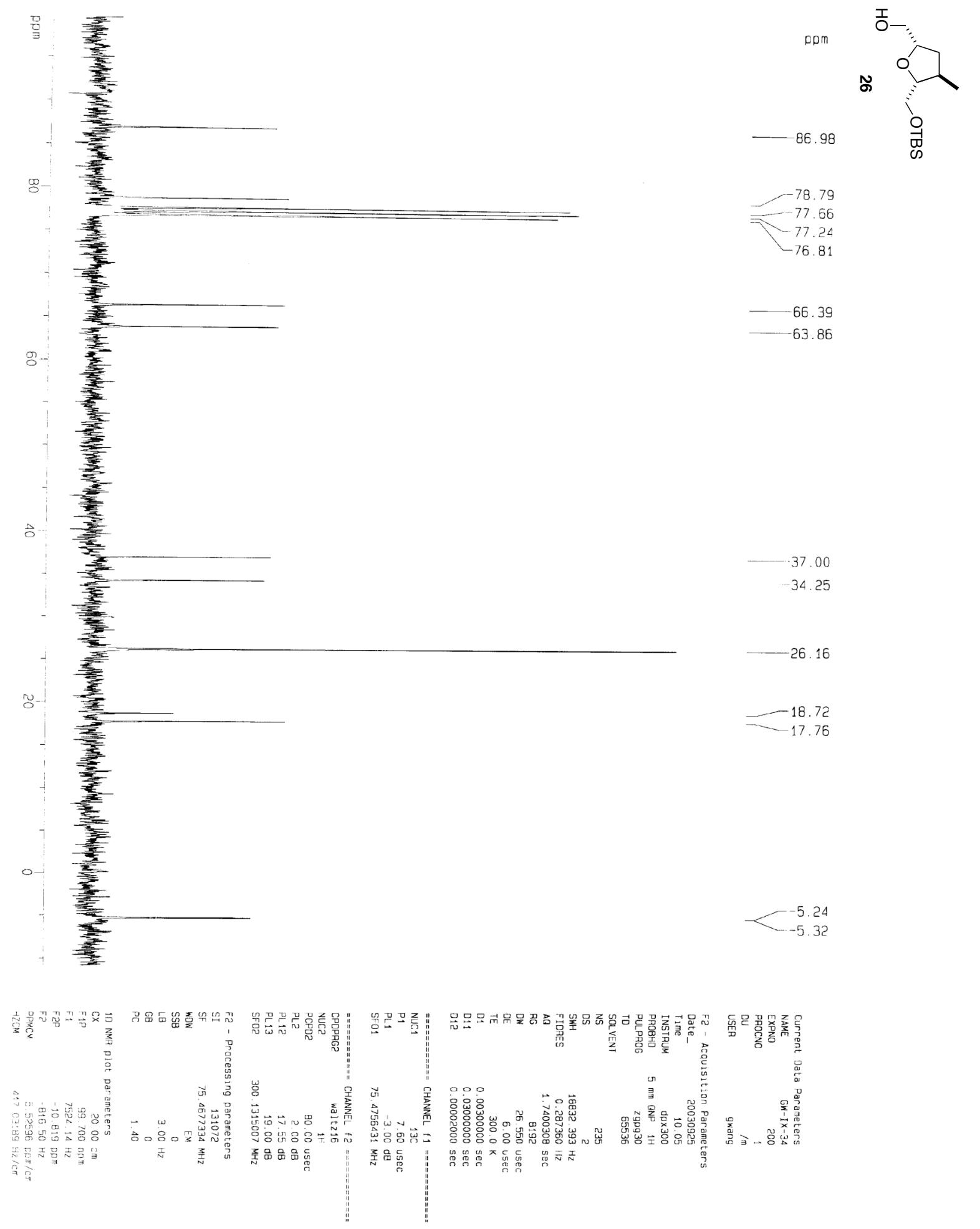


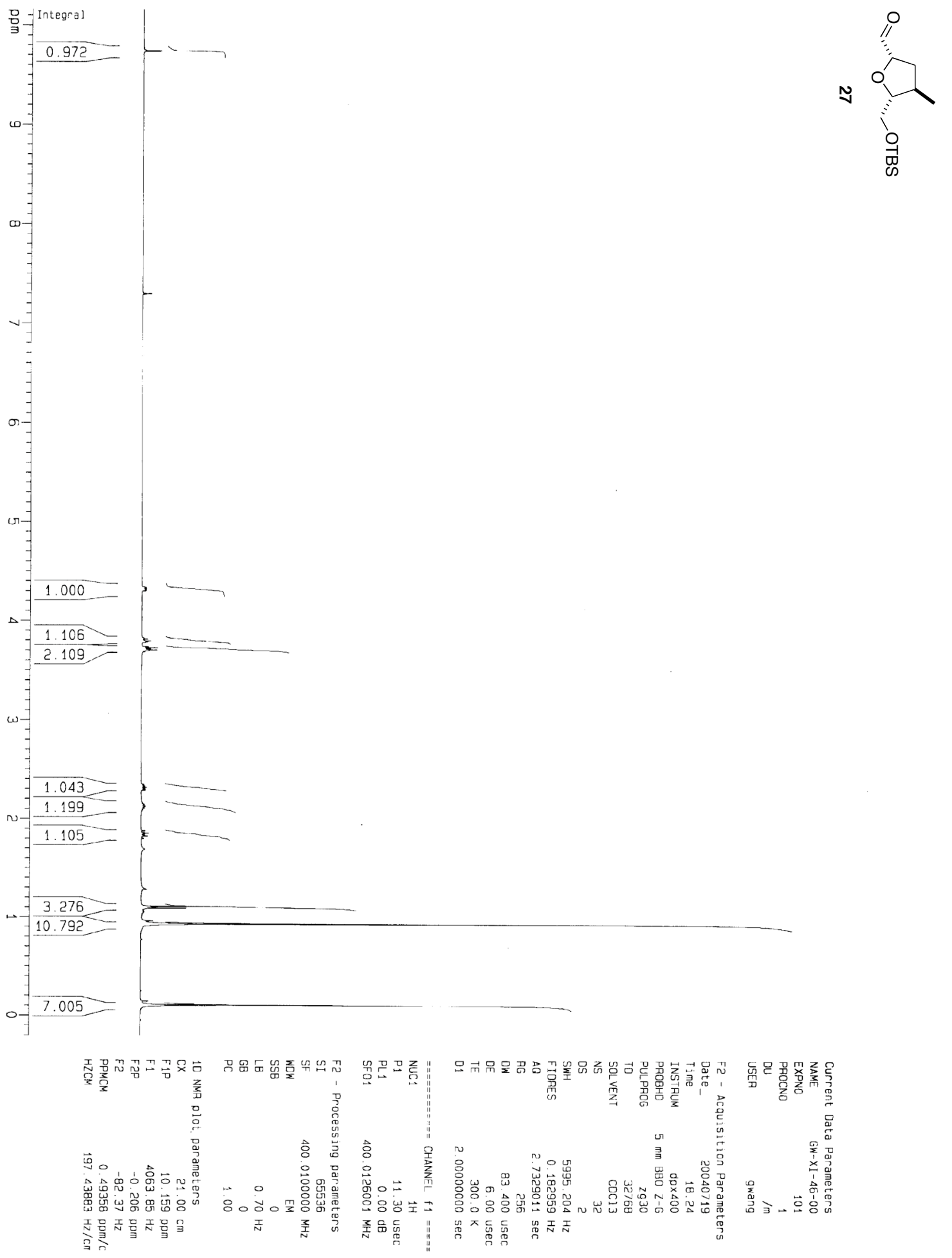




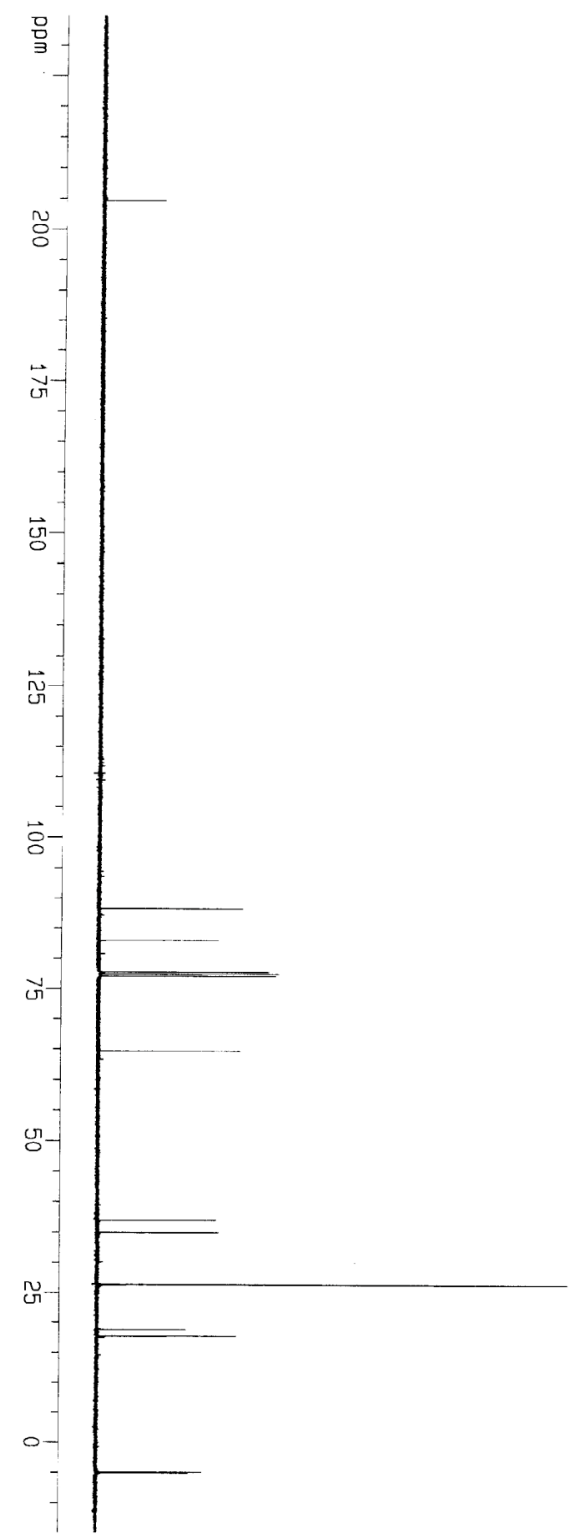

ppm

ง
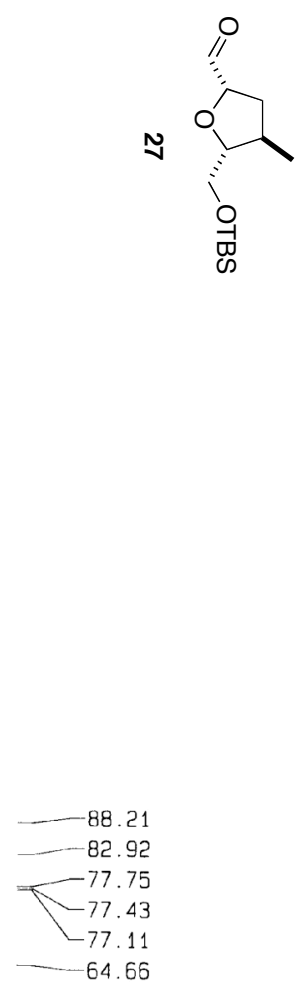

$\quad 37.02$
$-\quad 34.97$

$-26.34$

-18.80
$-\quad 17.75$

-4.95
+-5.04
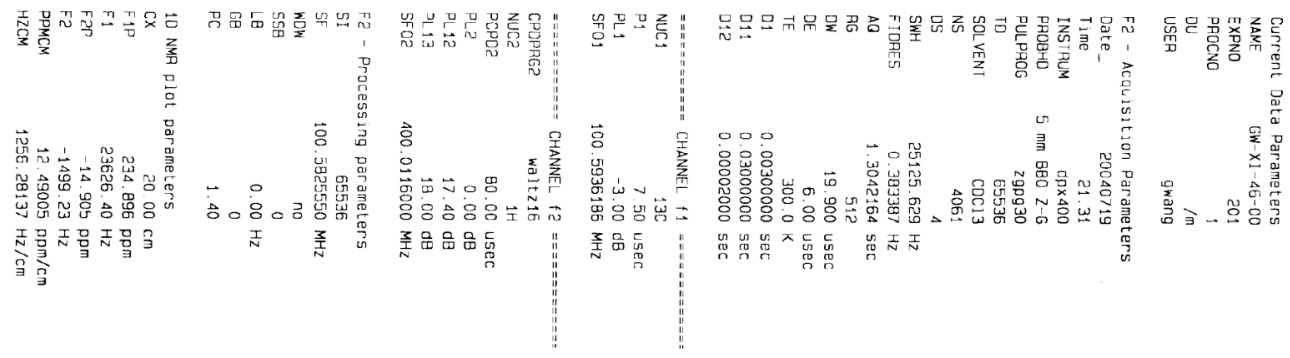


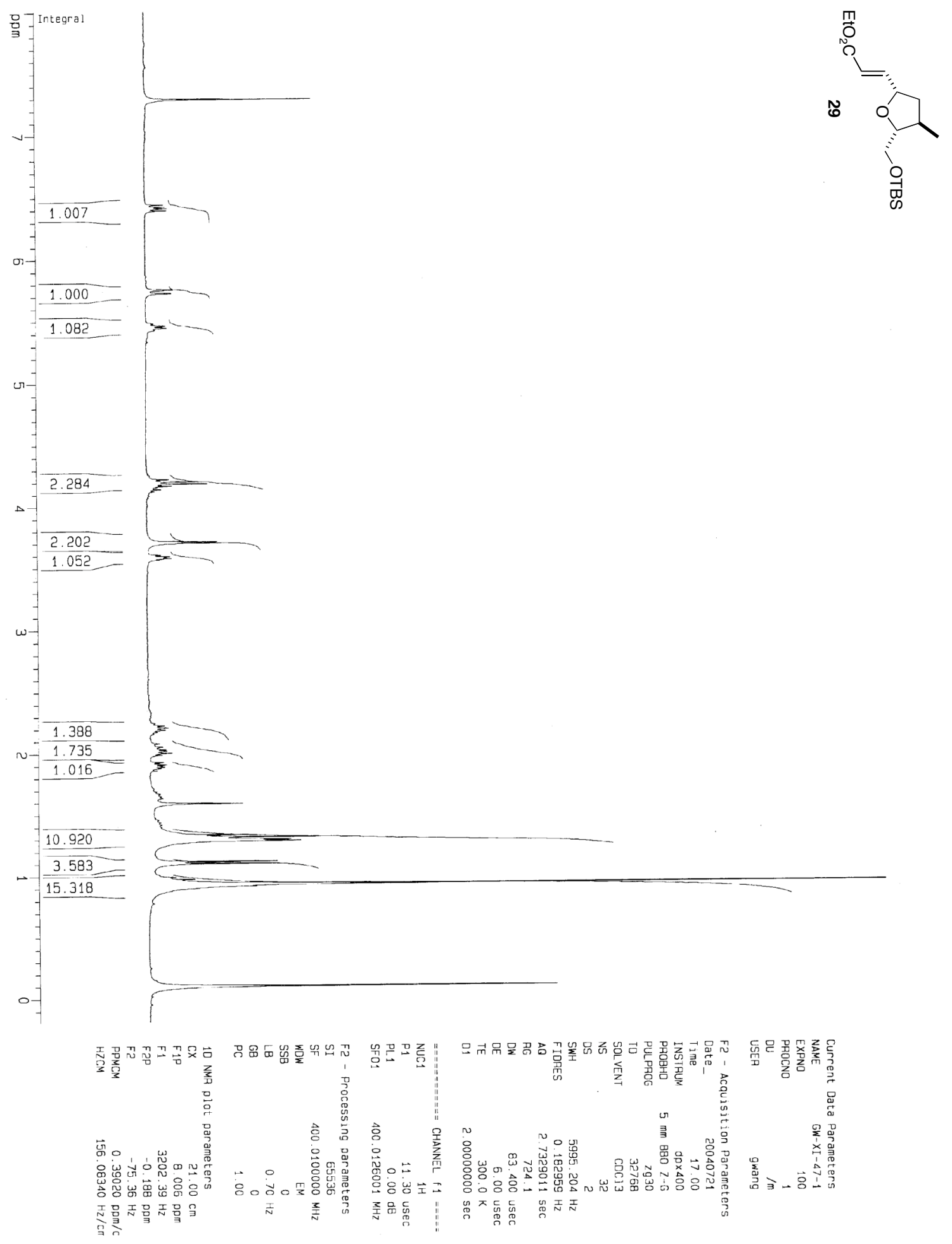




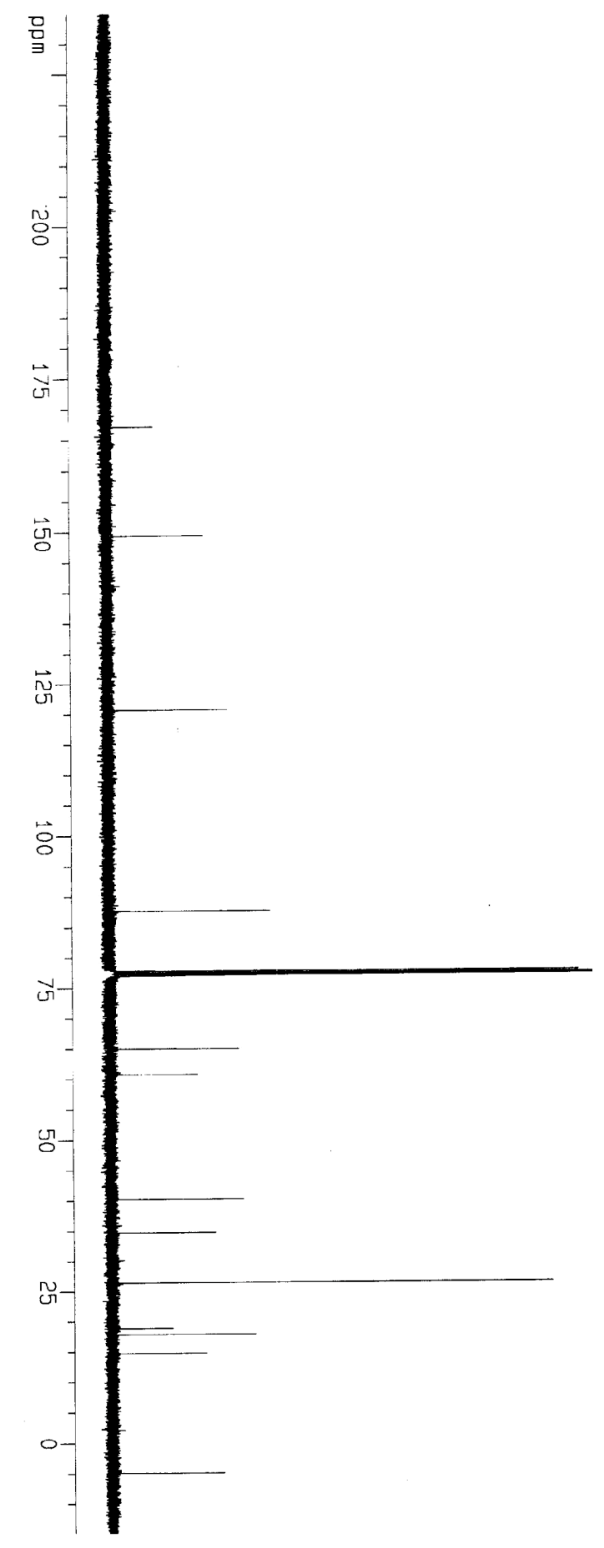

$p p m$
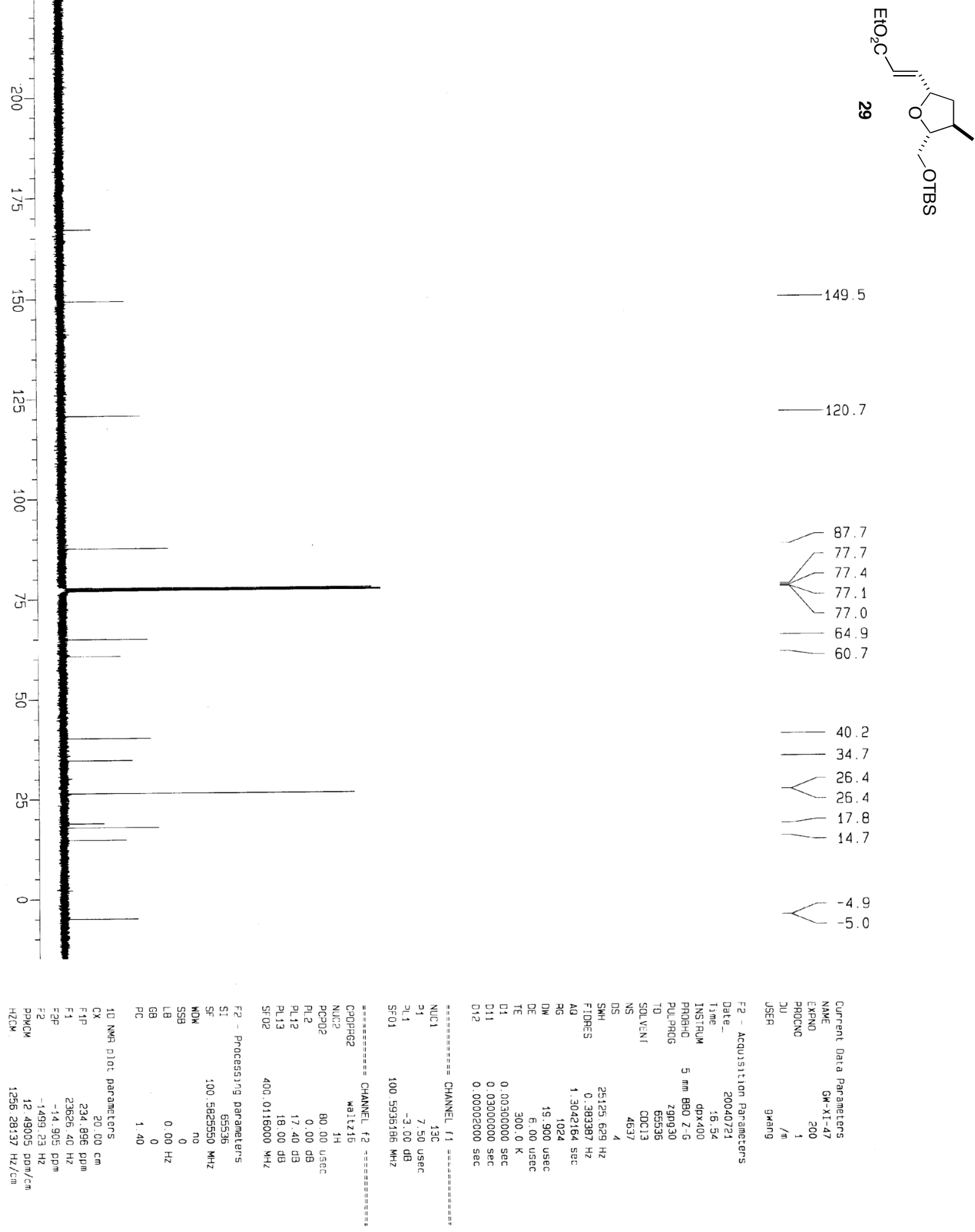


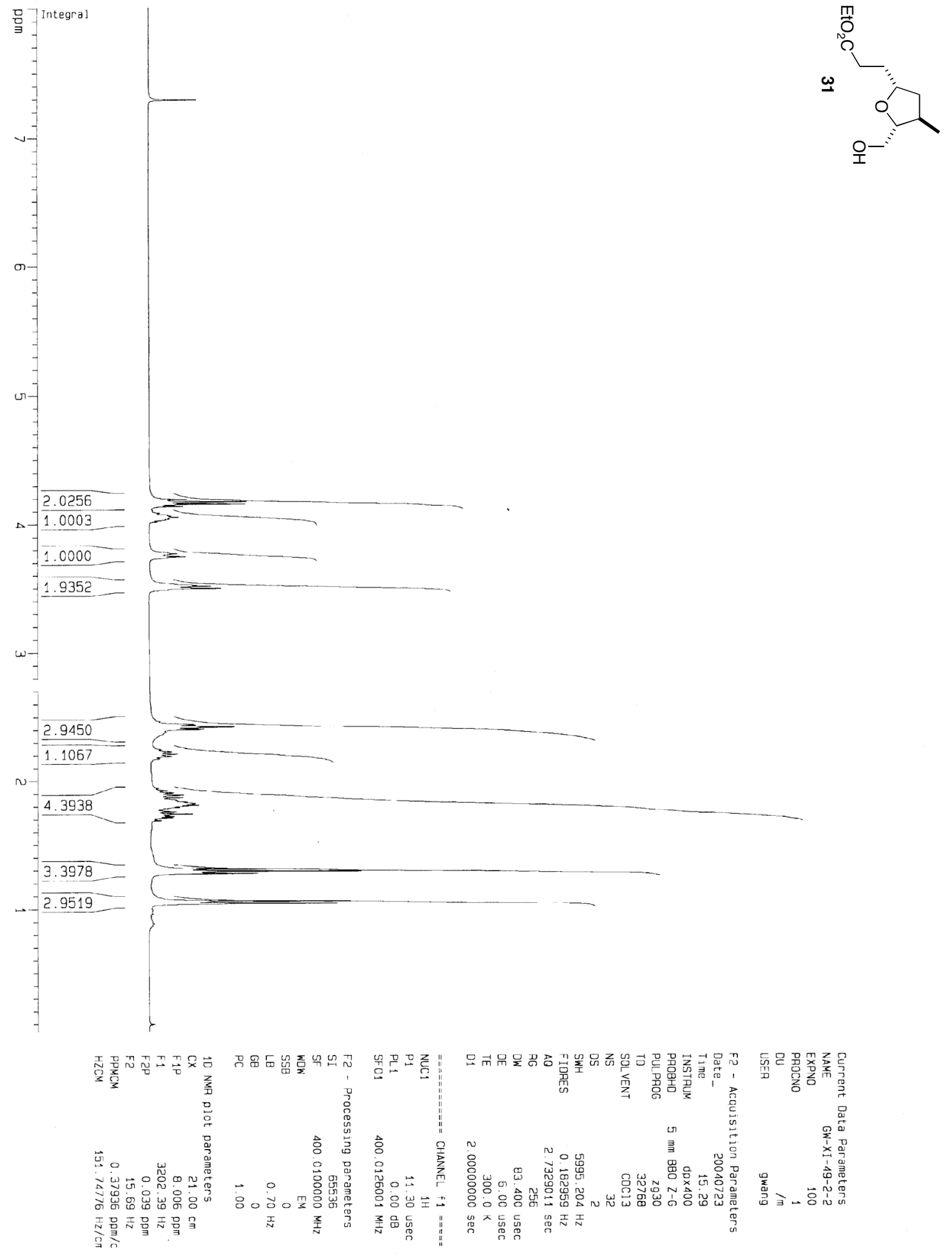




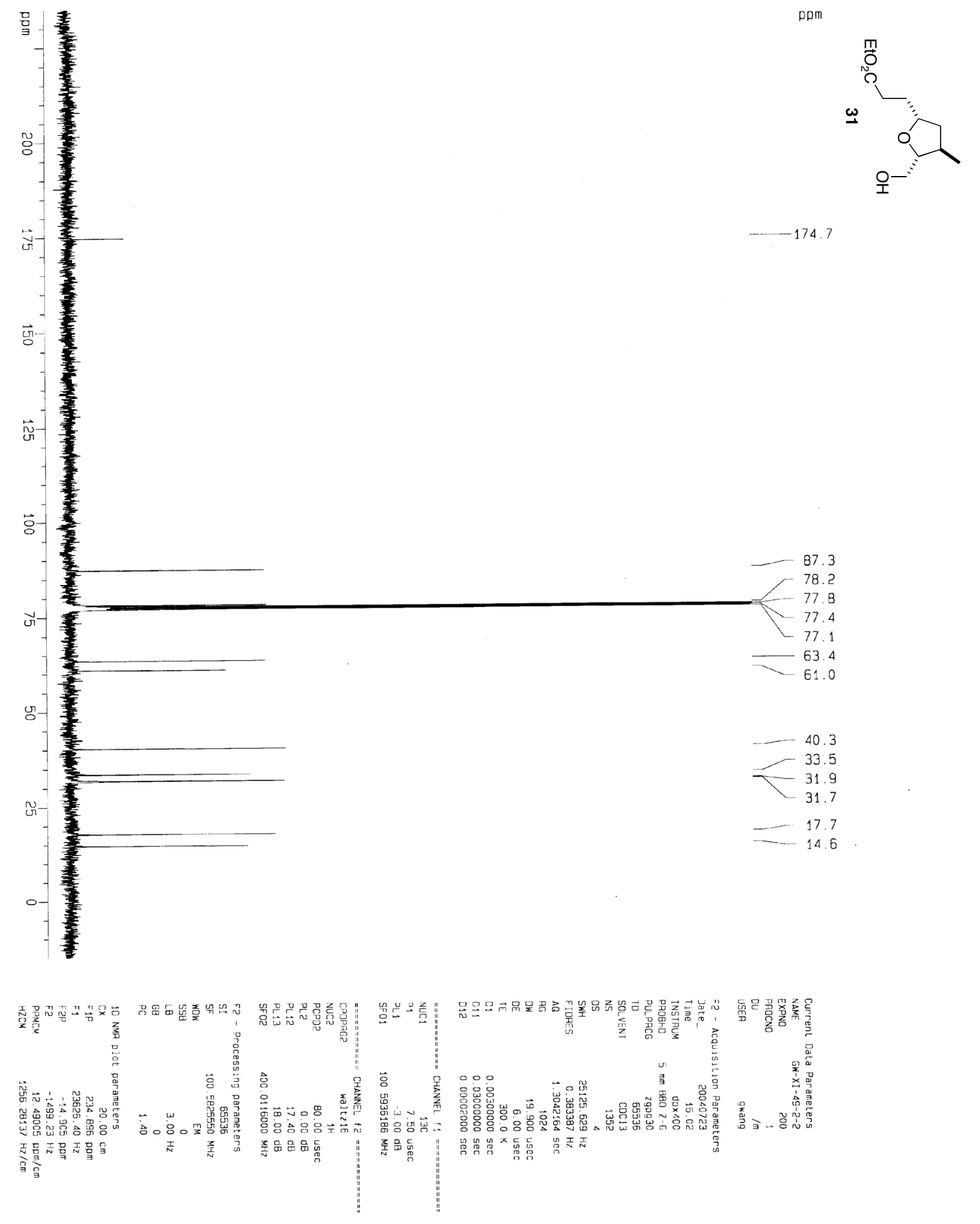




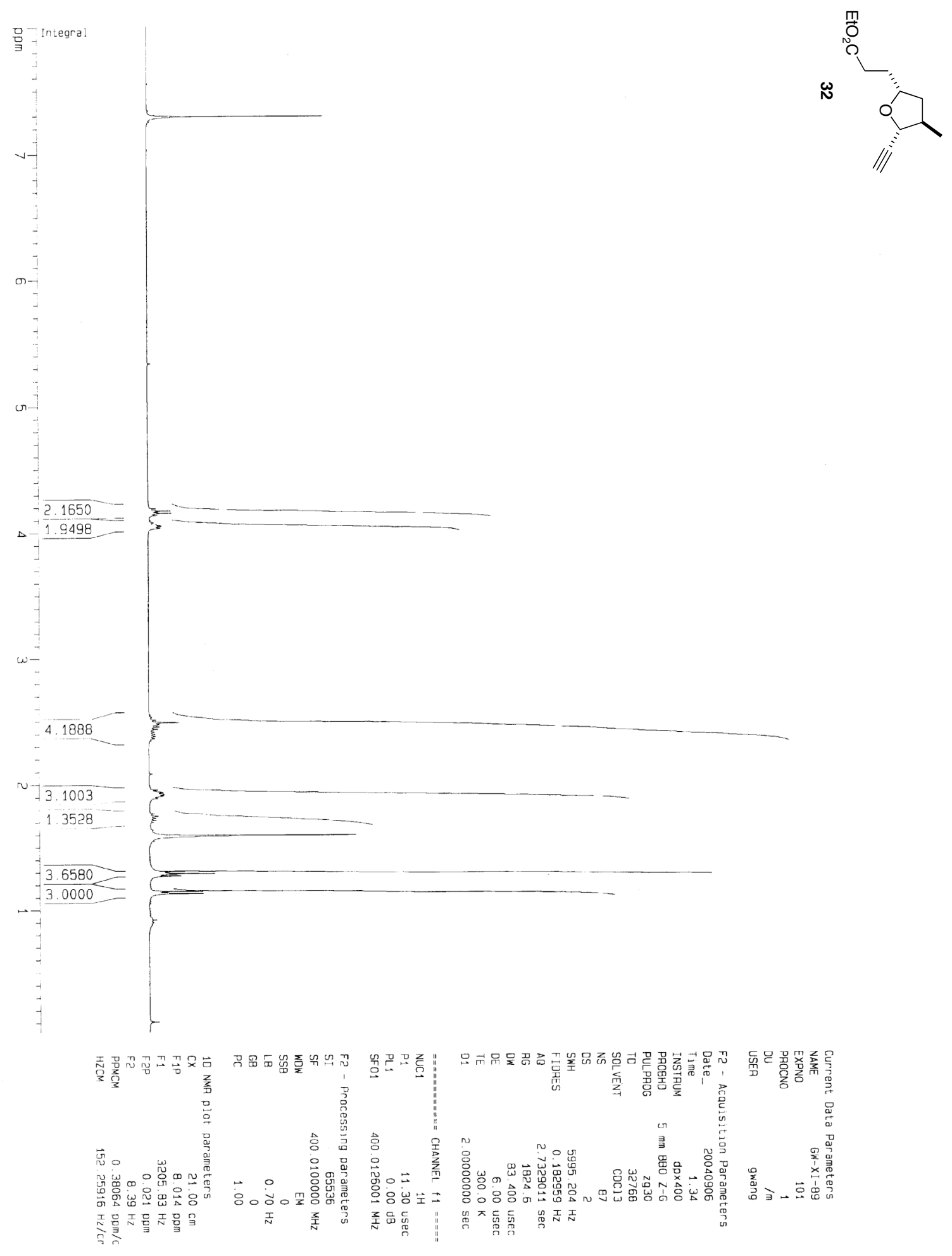



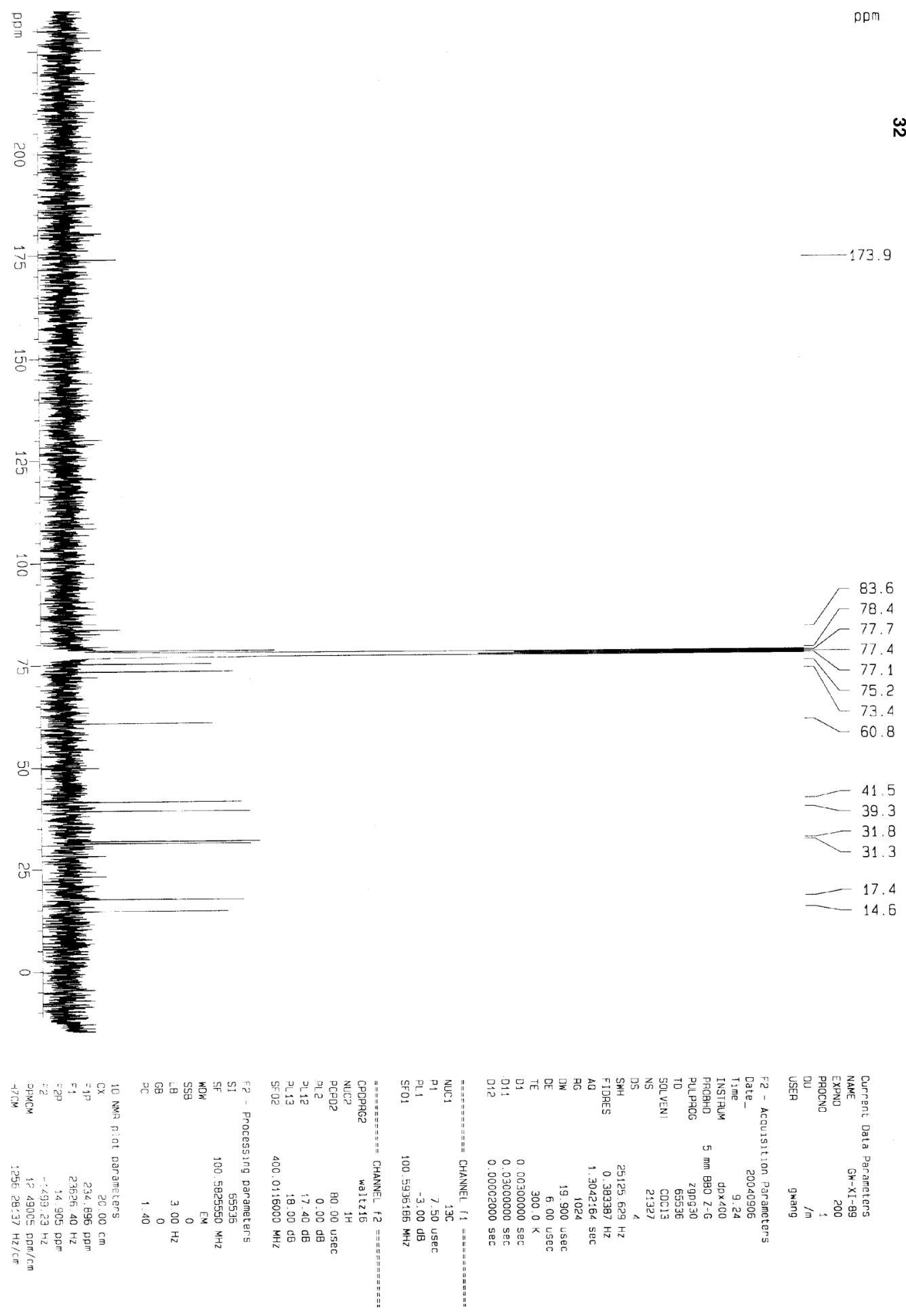


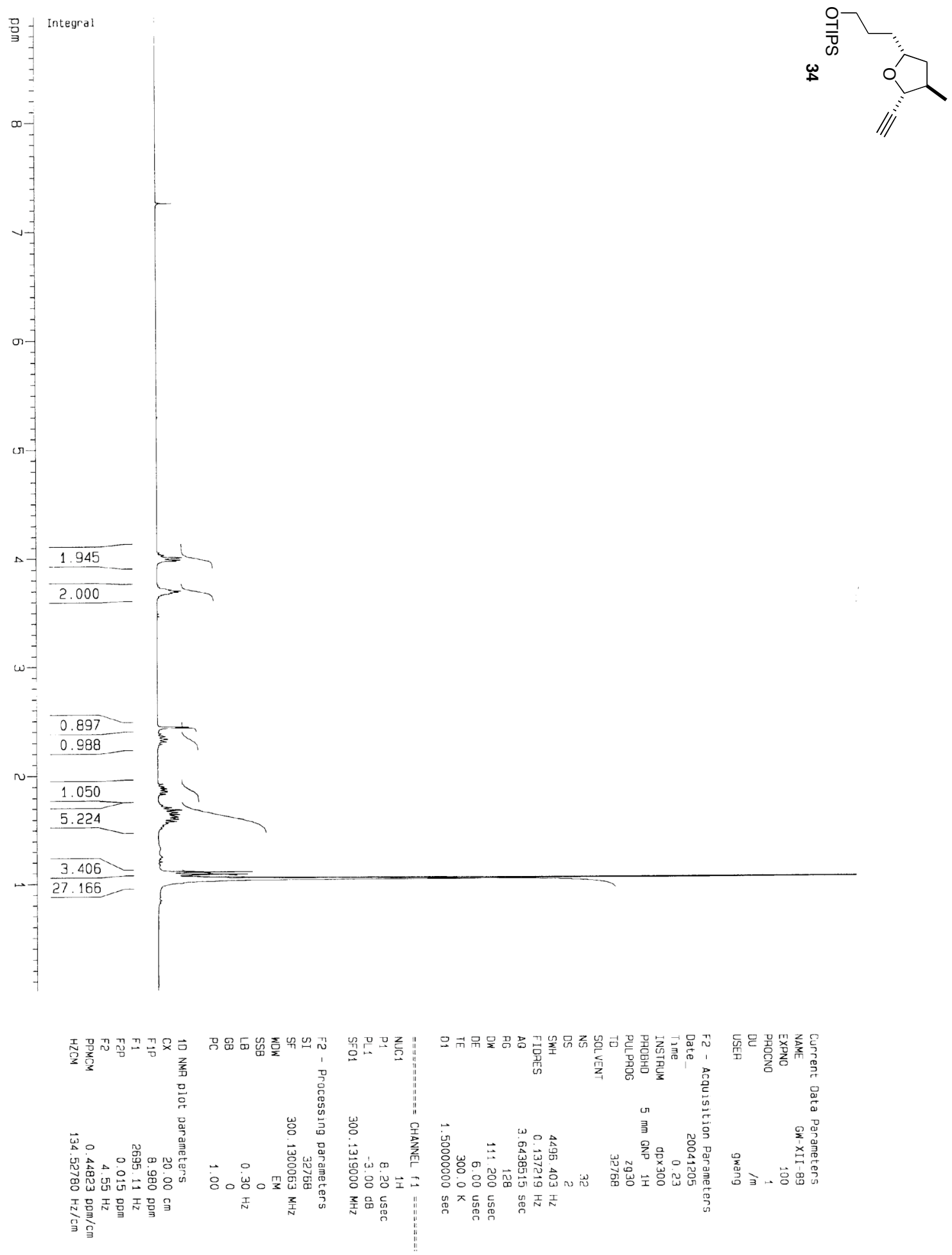




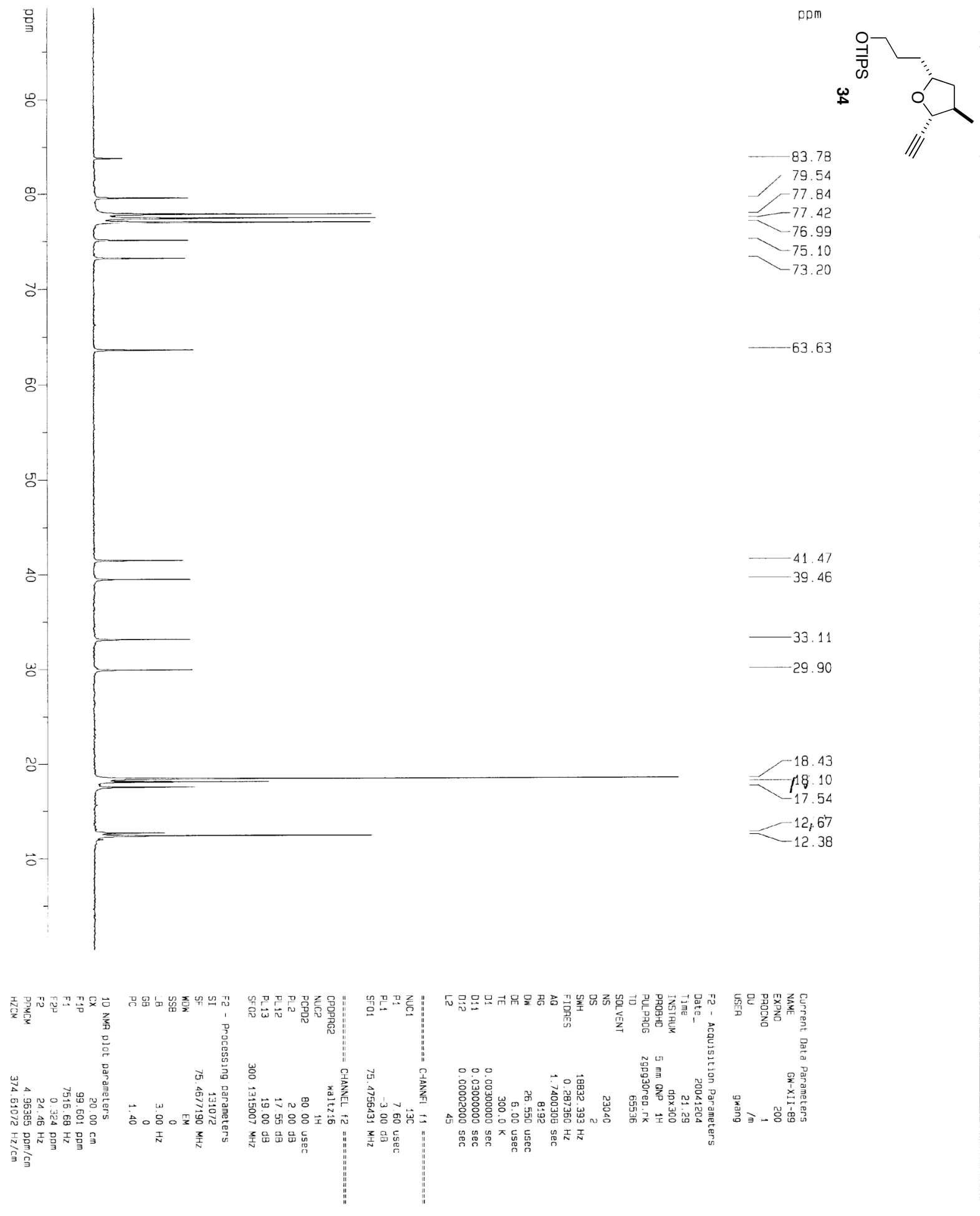




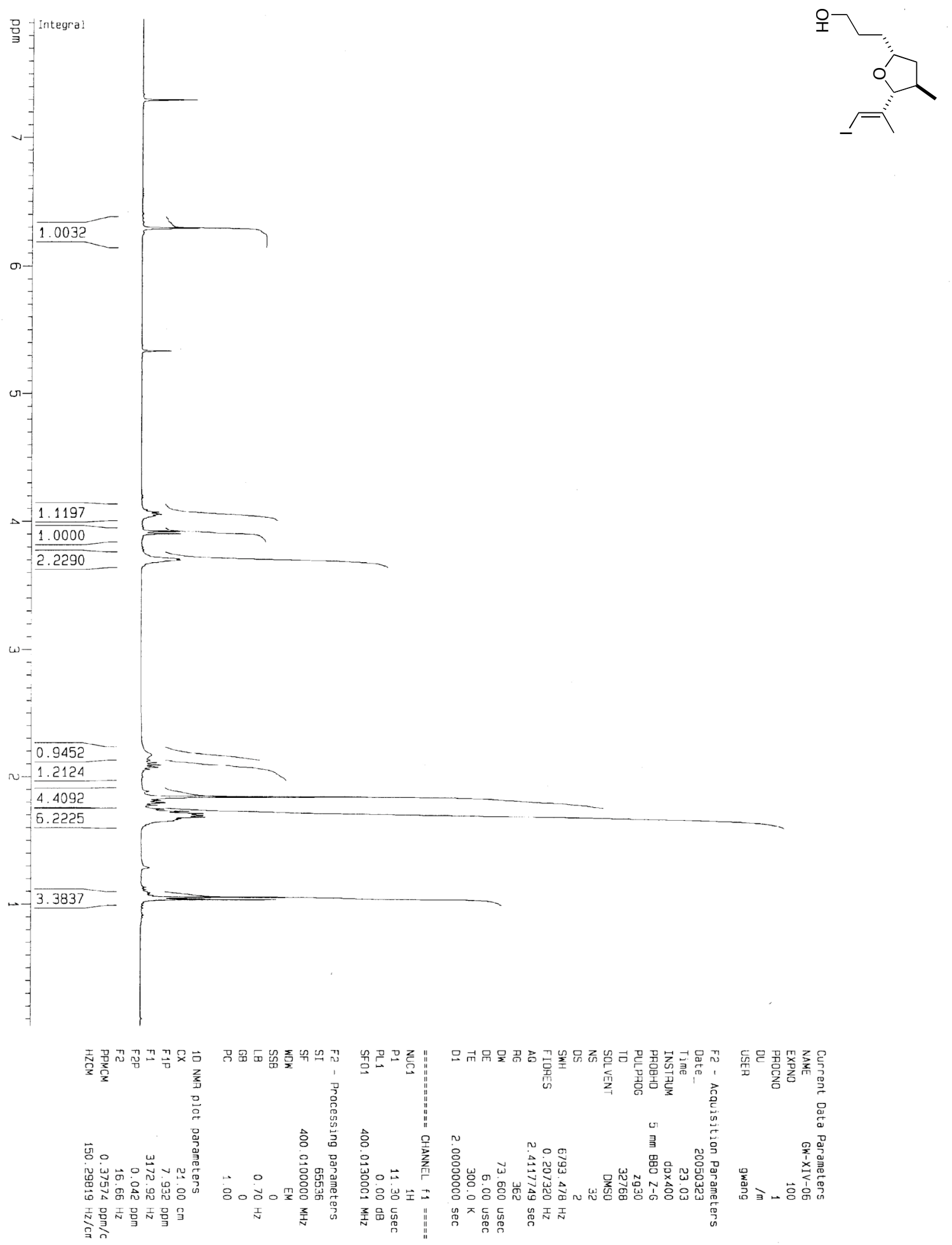




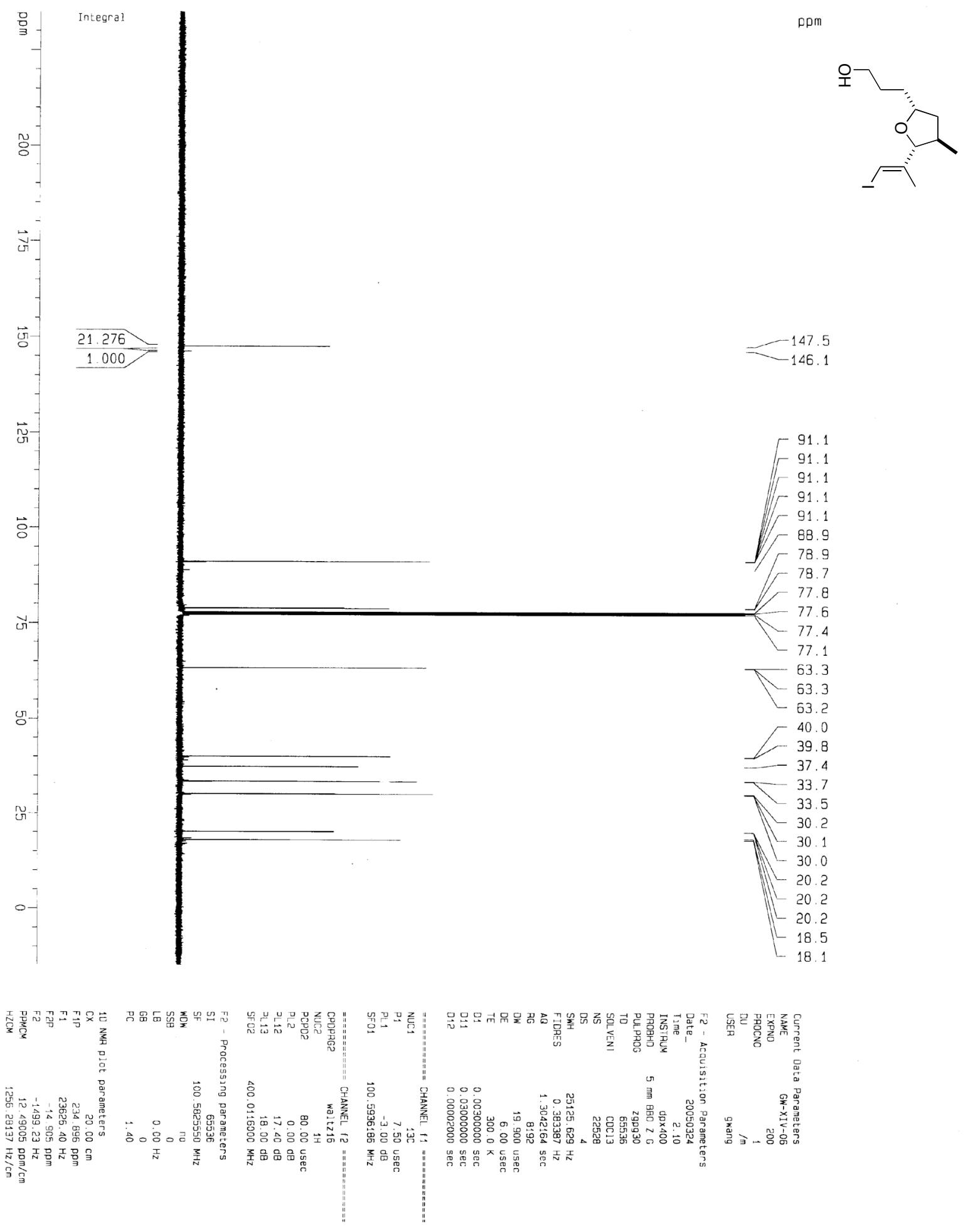




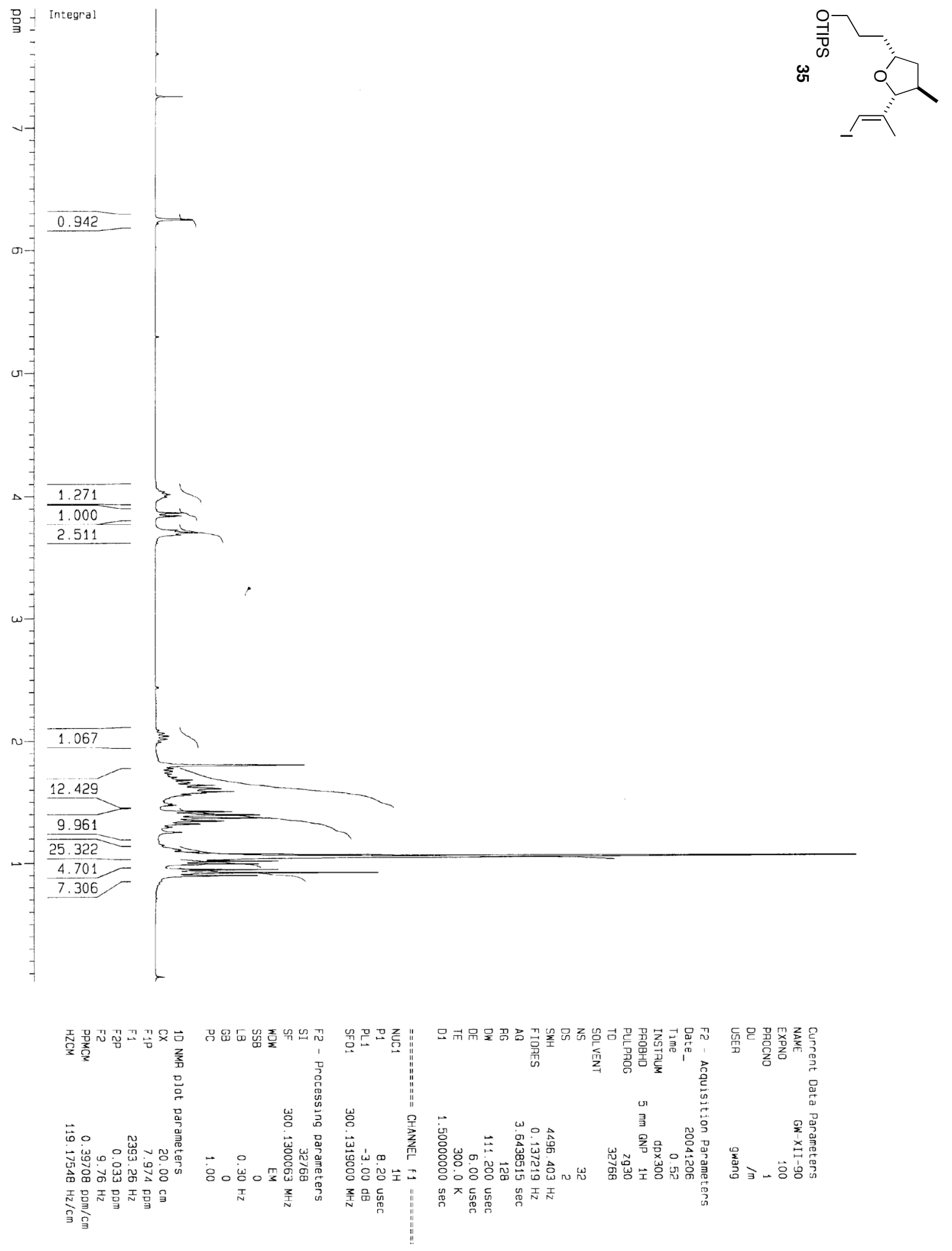




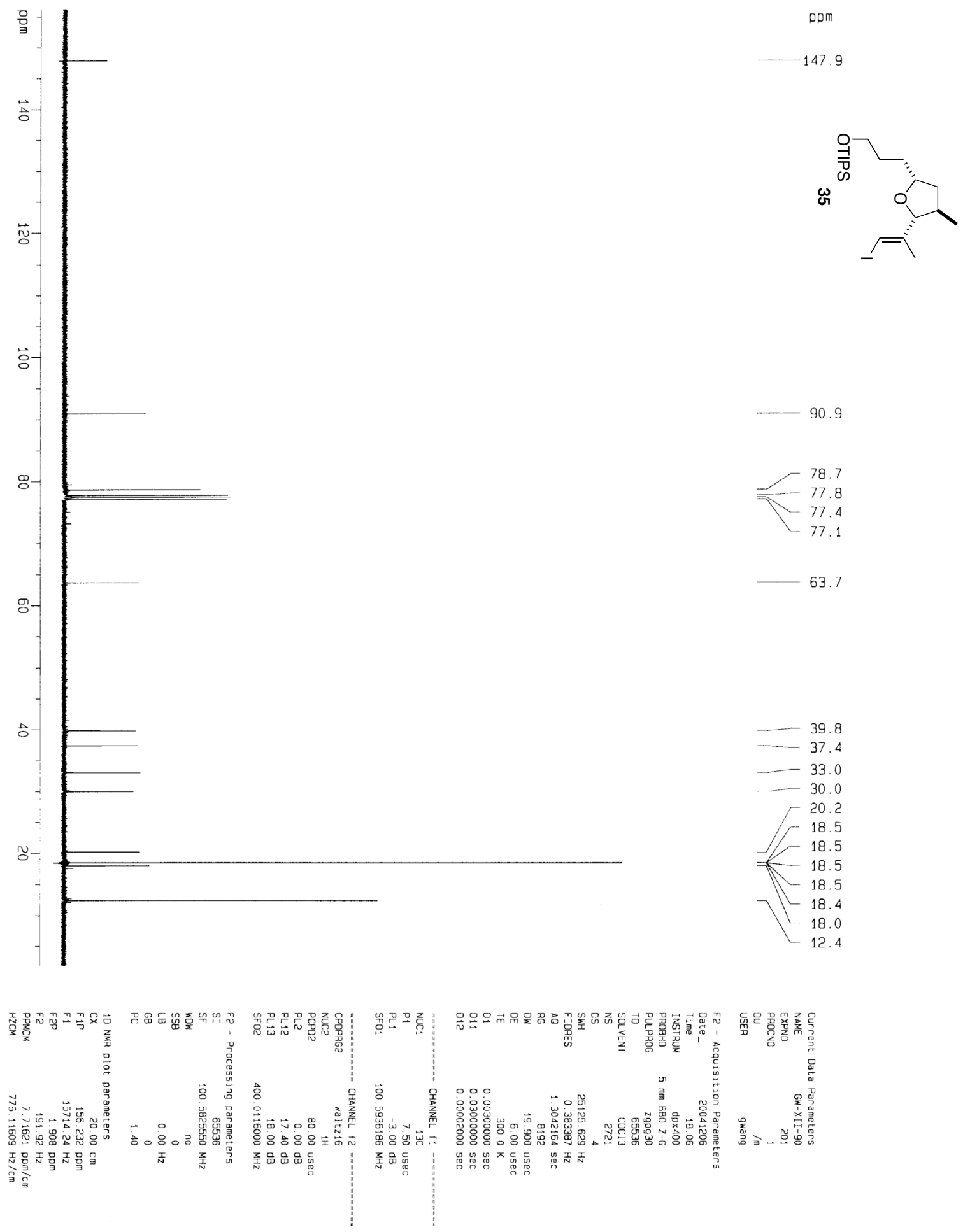




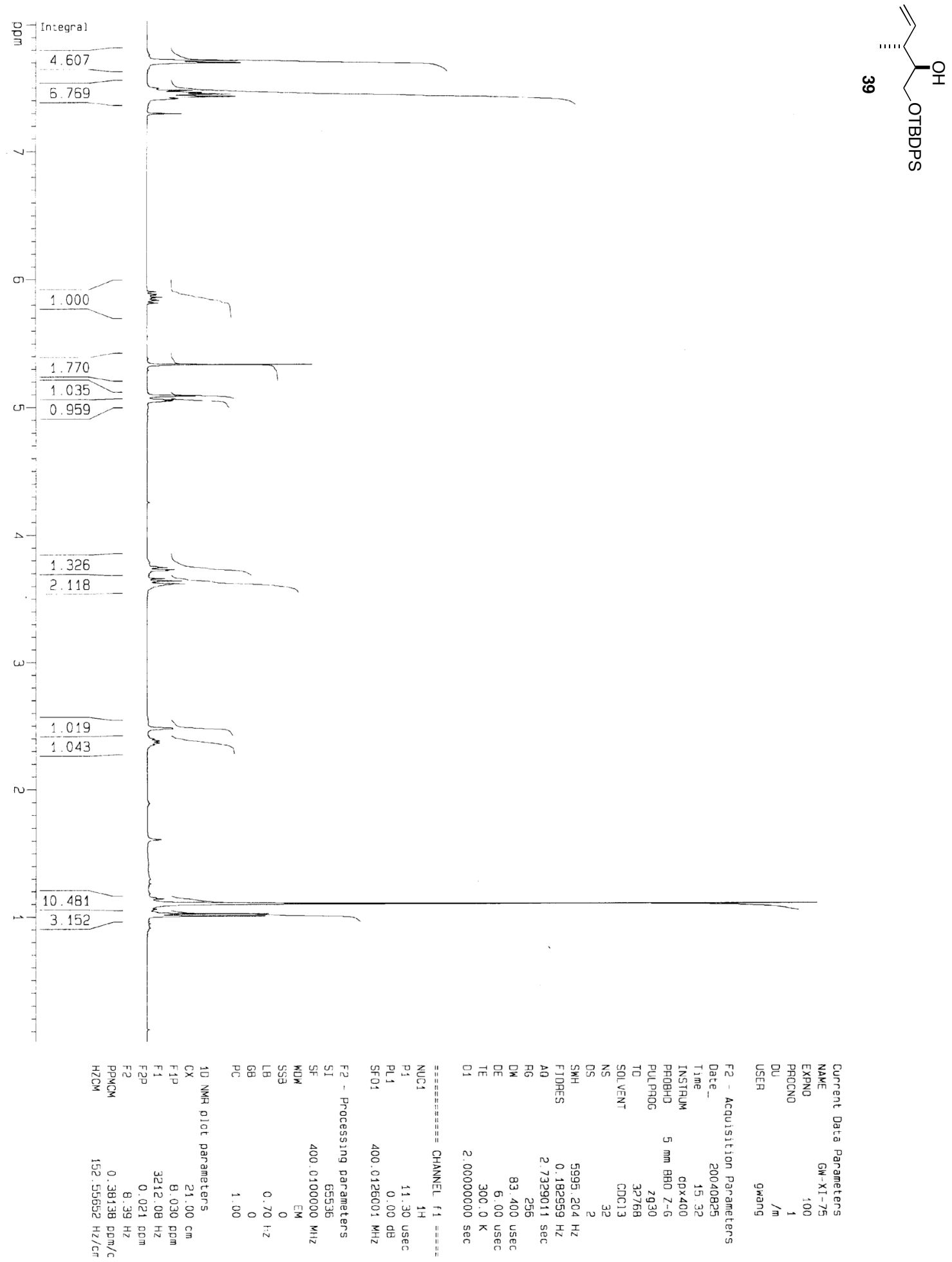




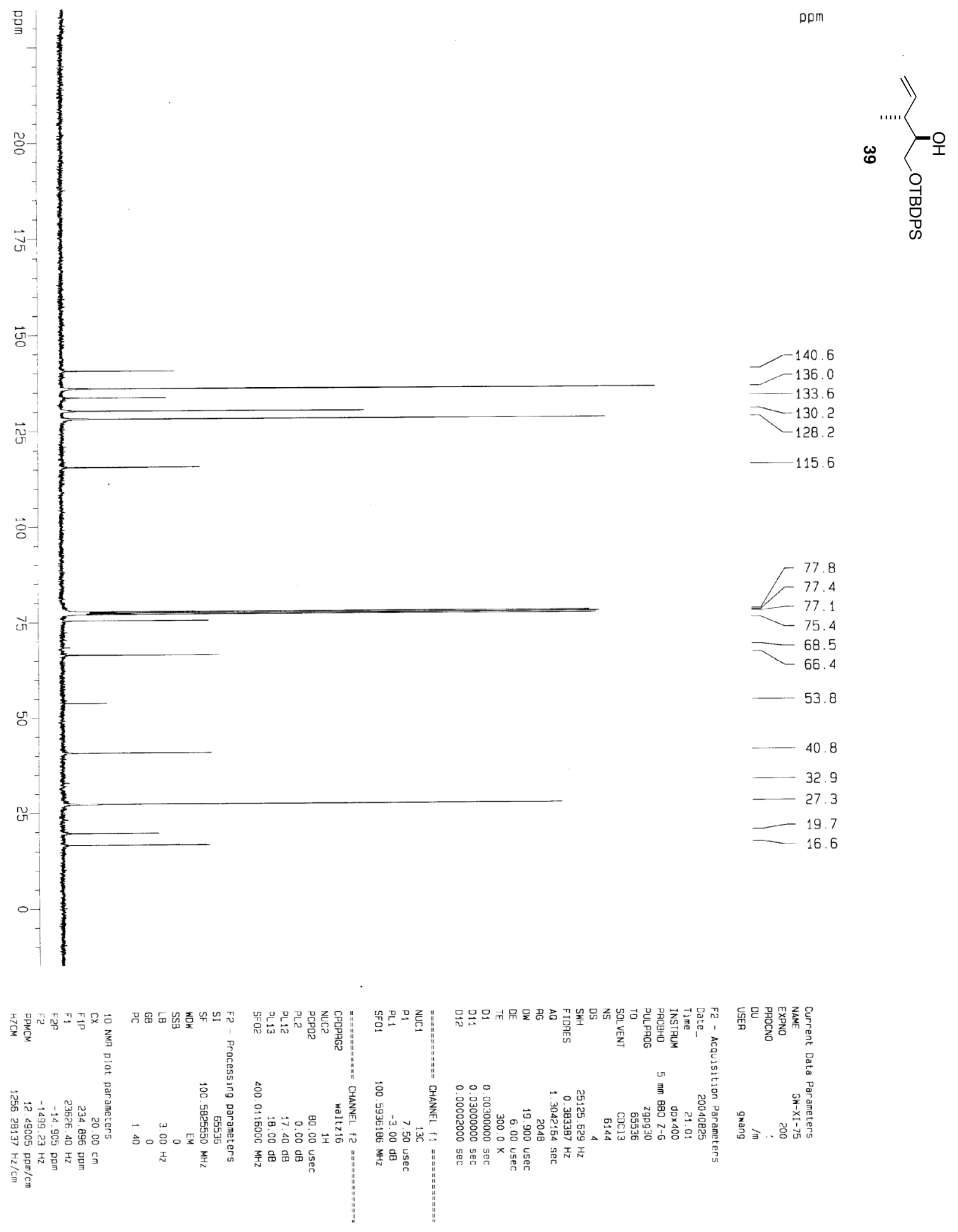




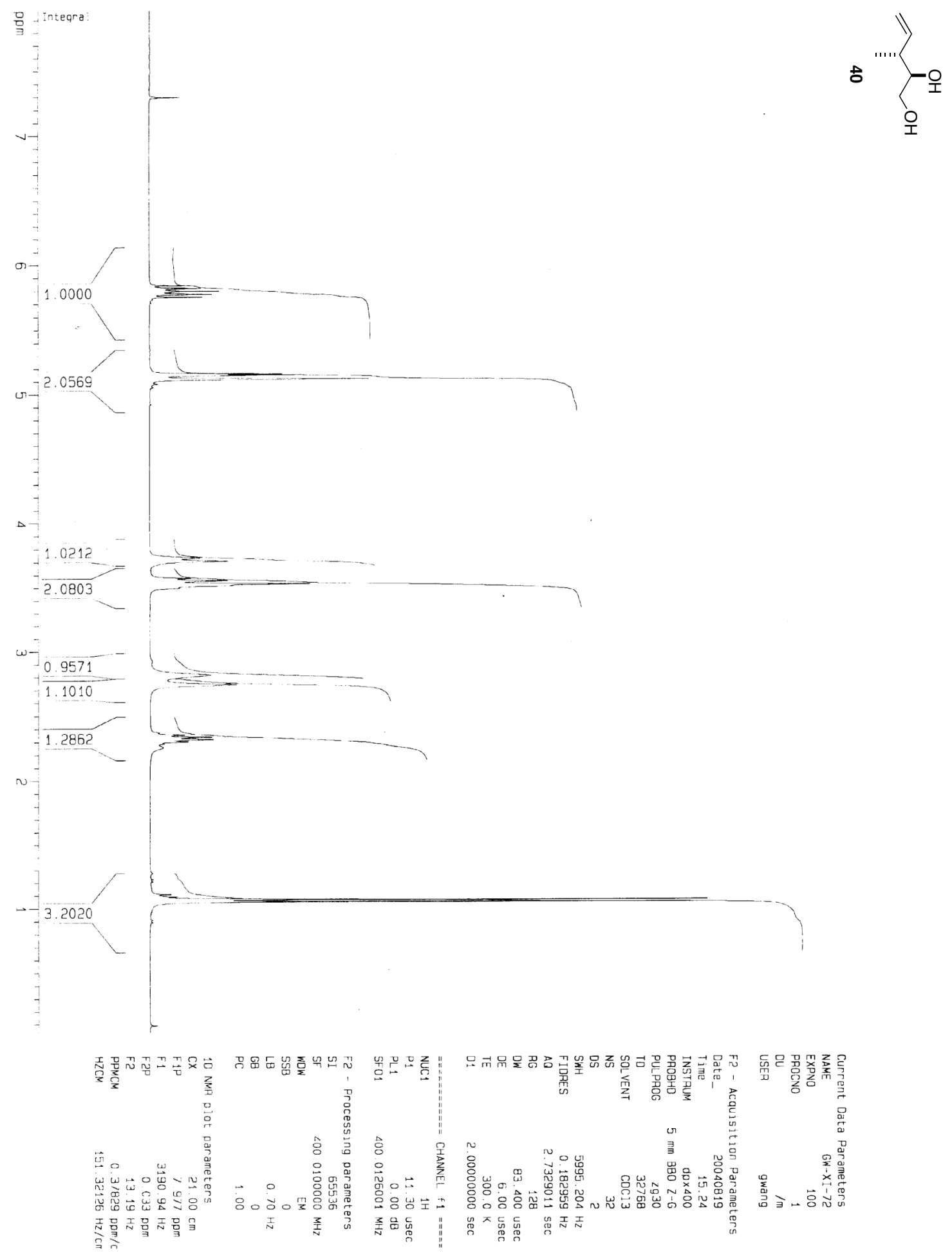




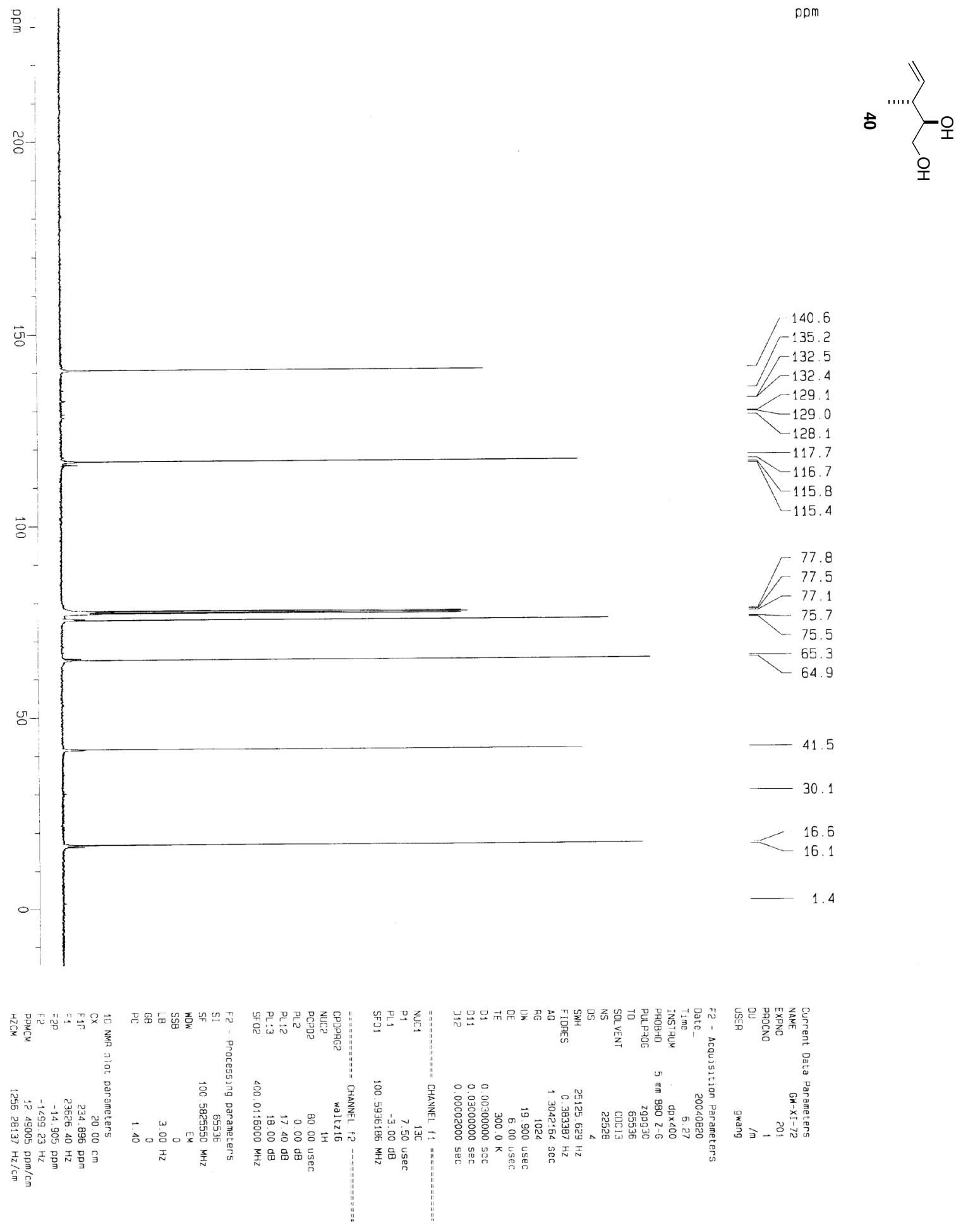




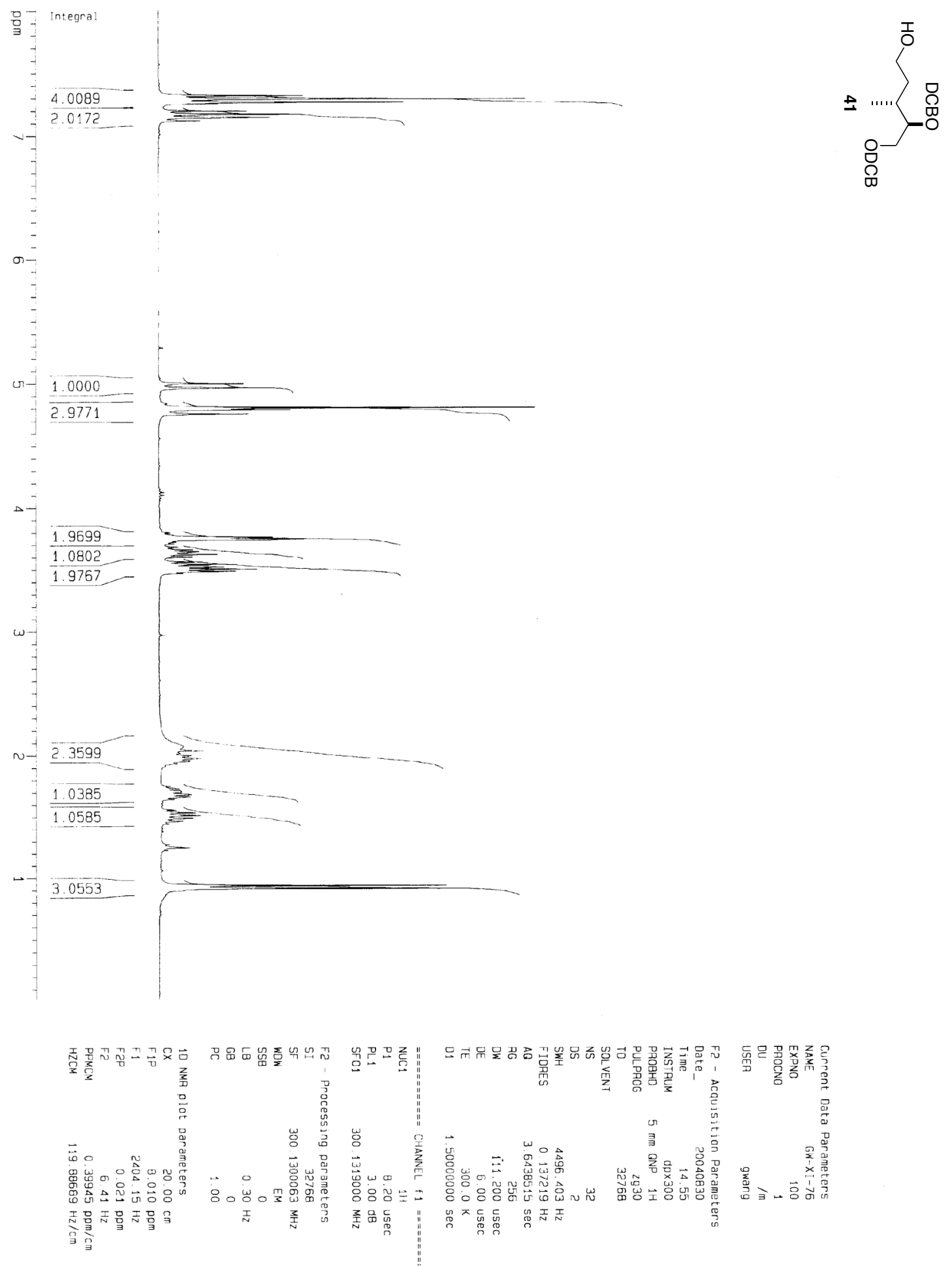




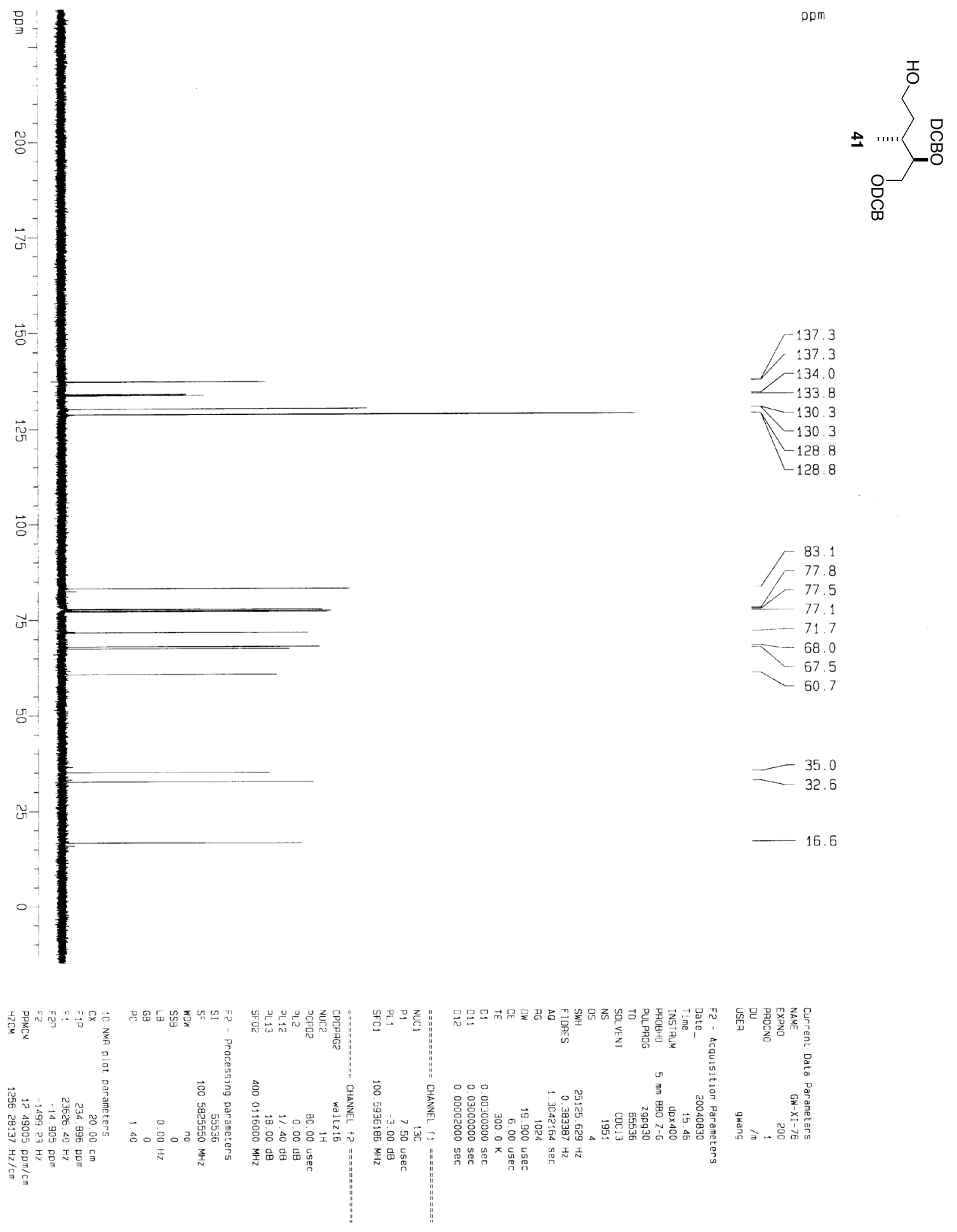




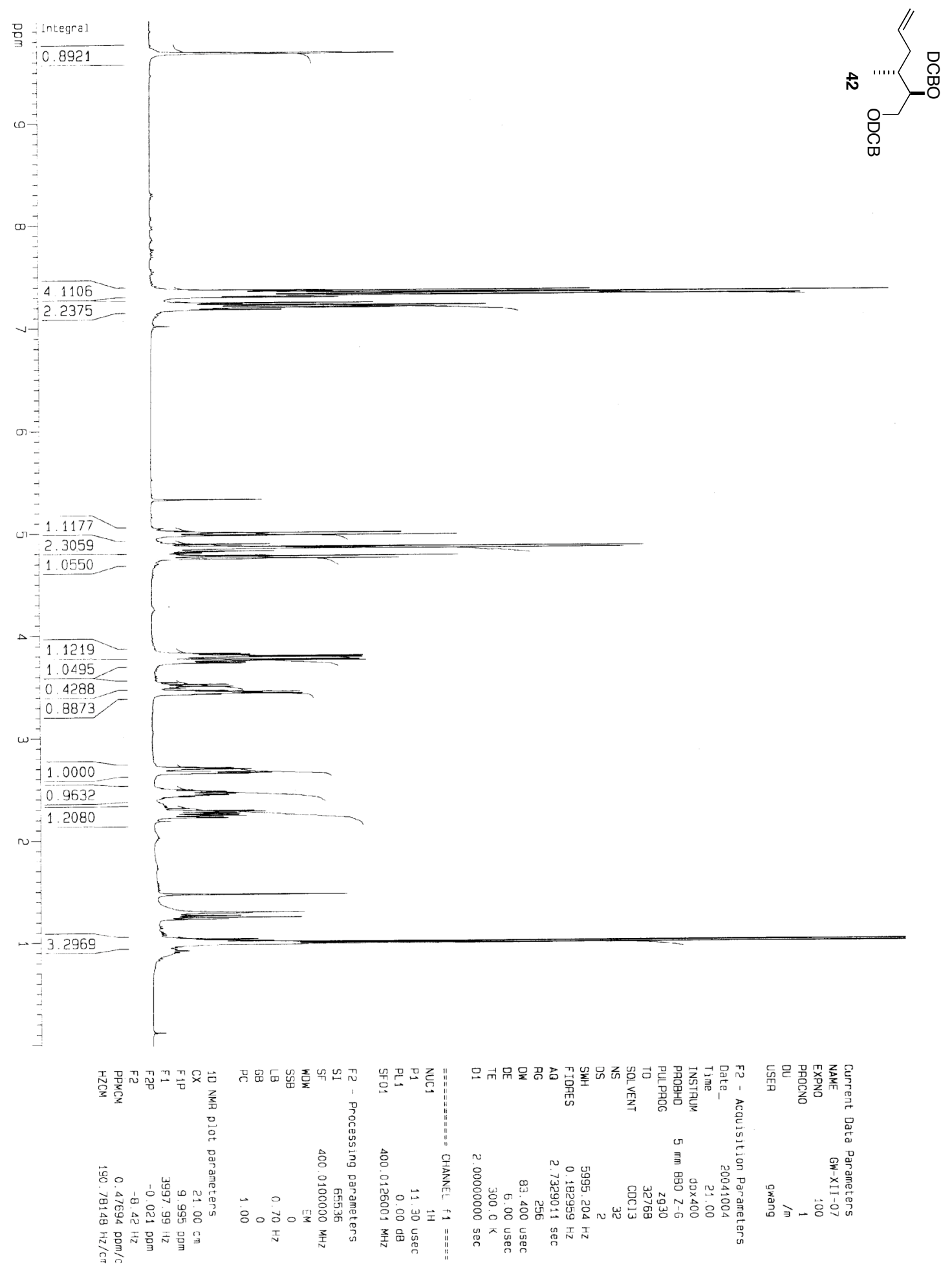




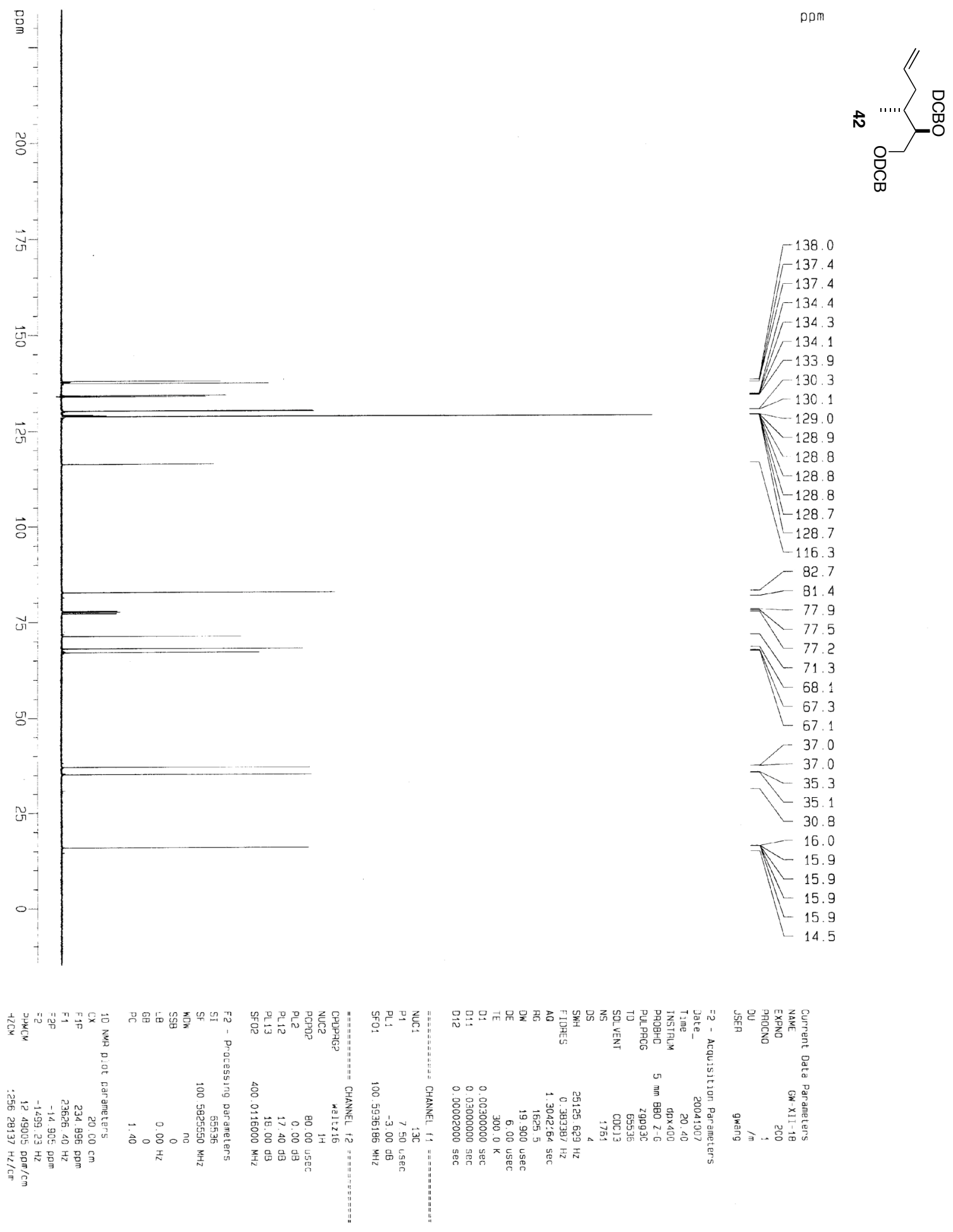




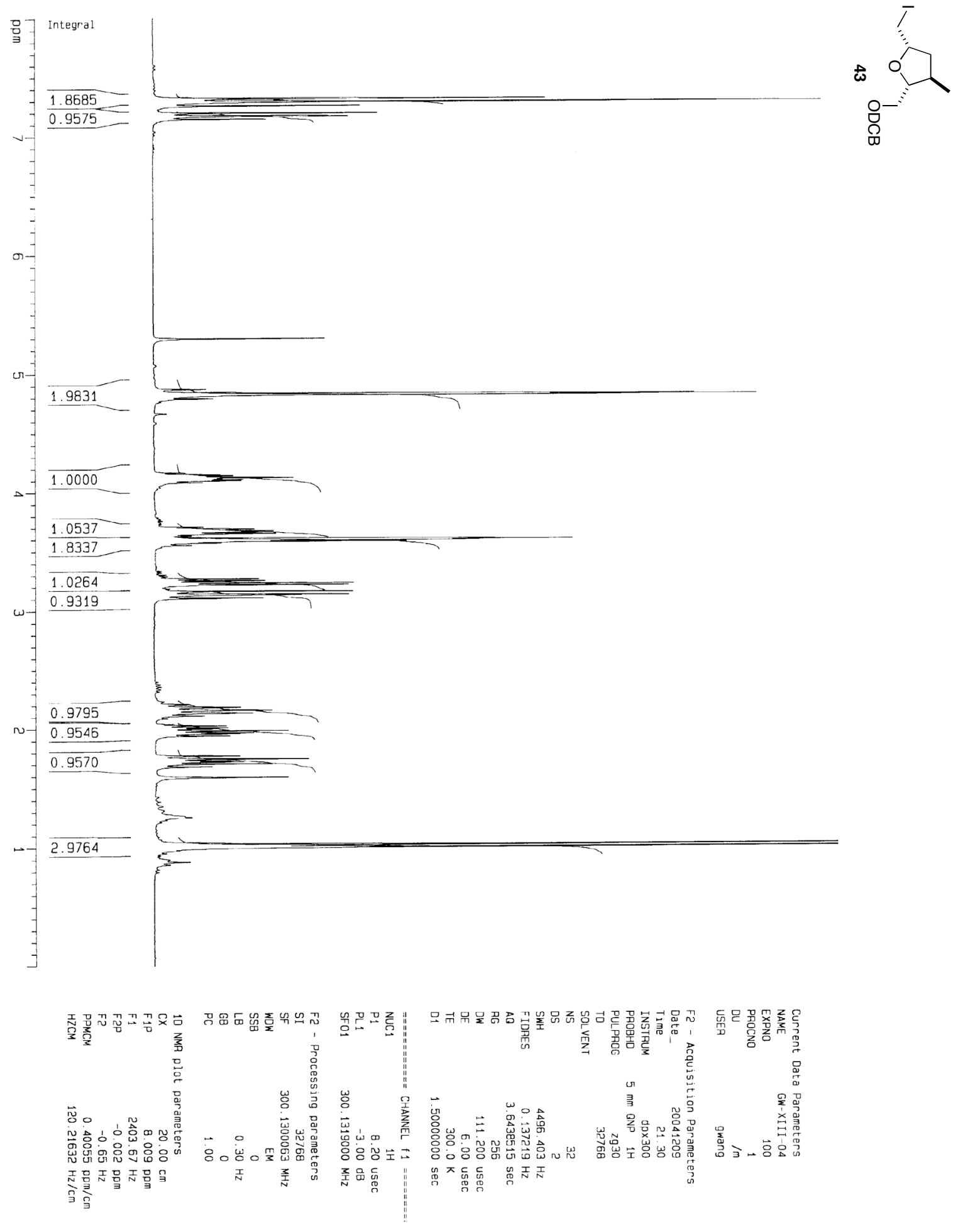



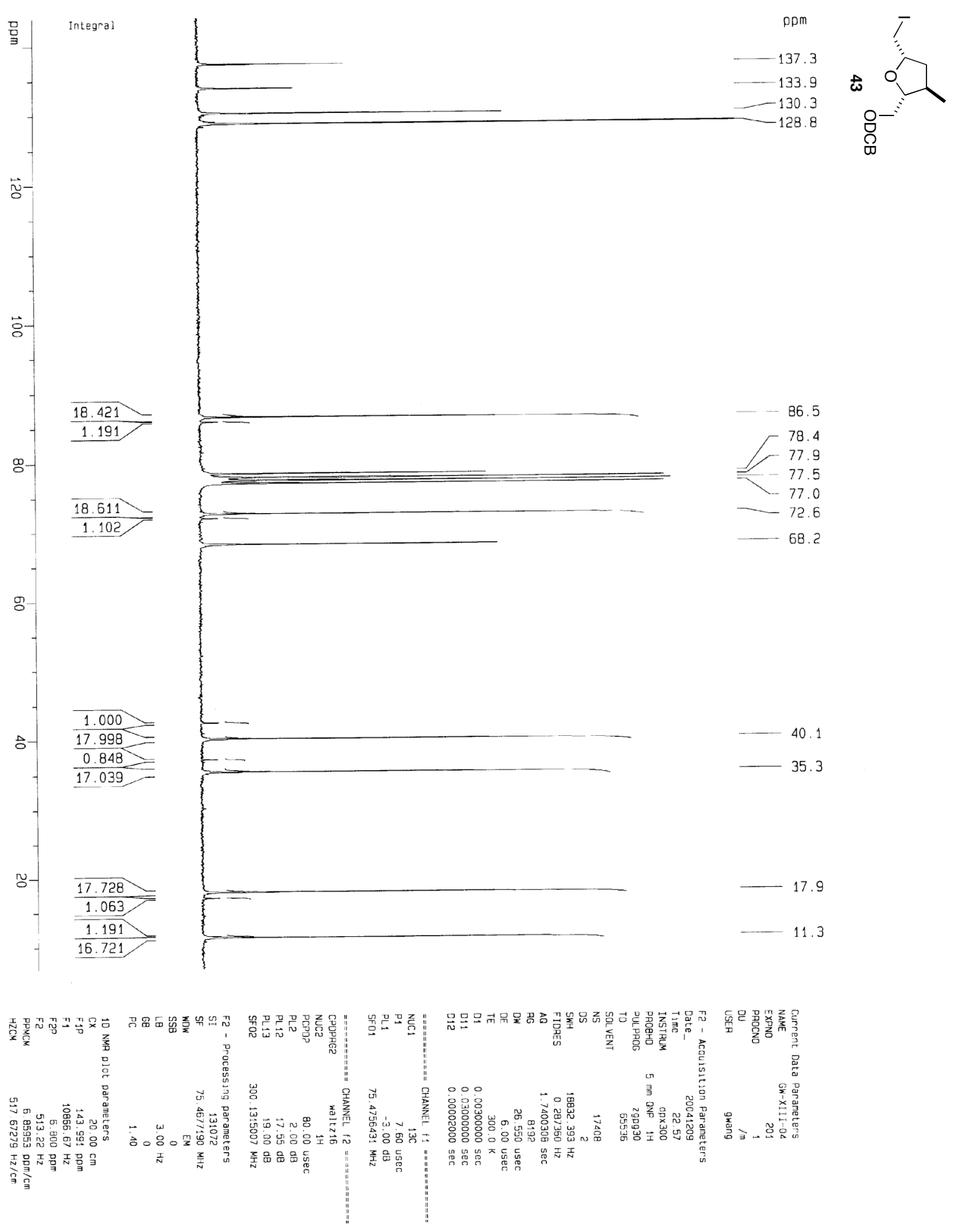


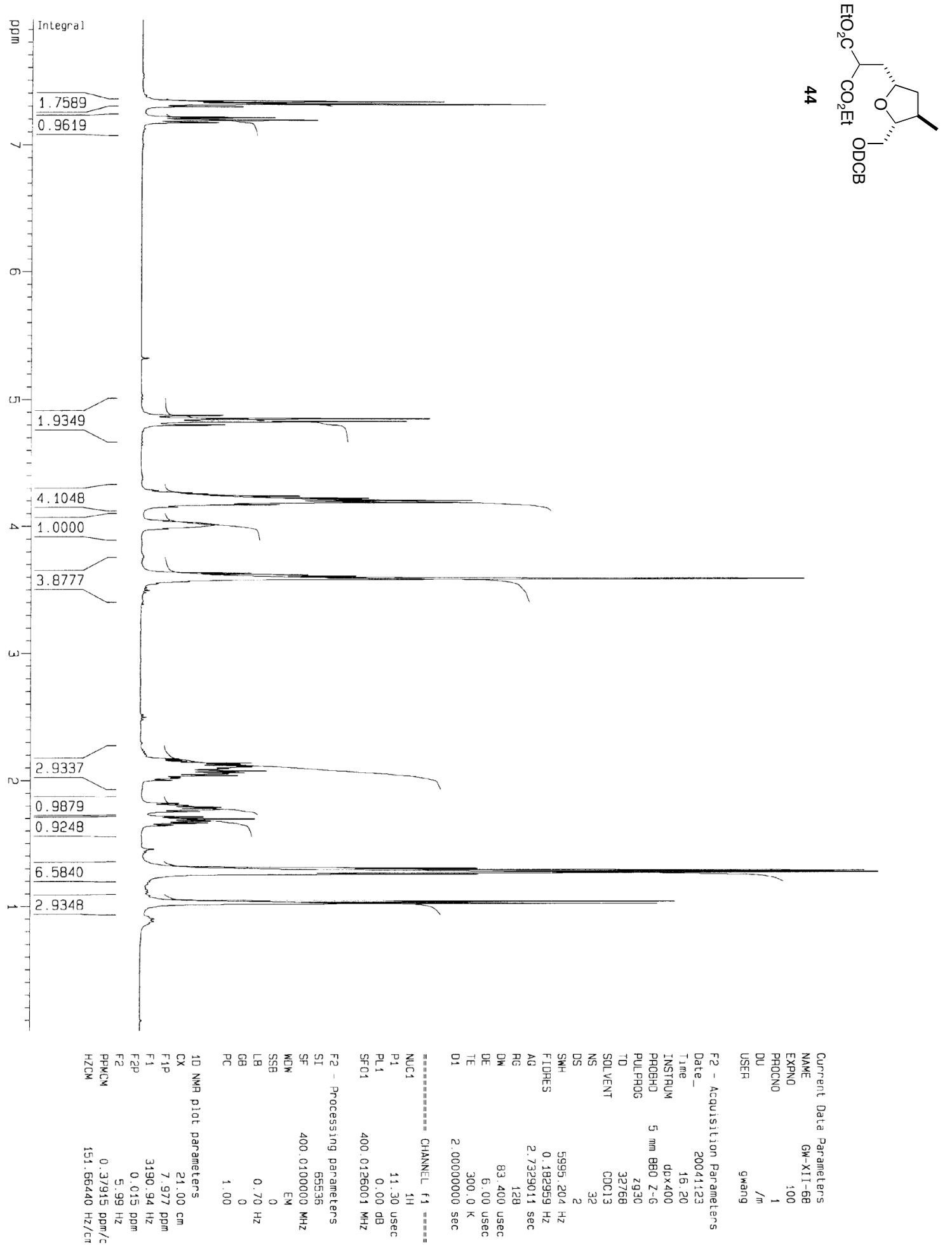



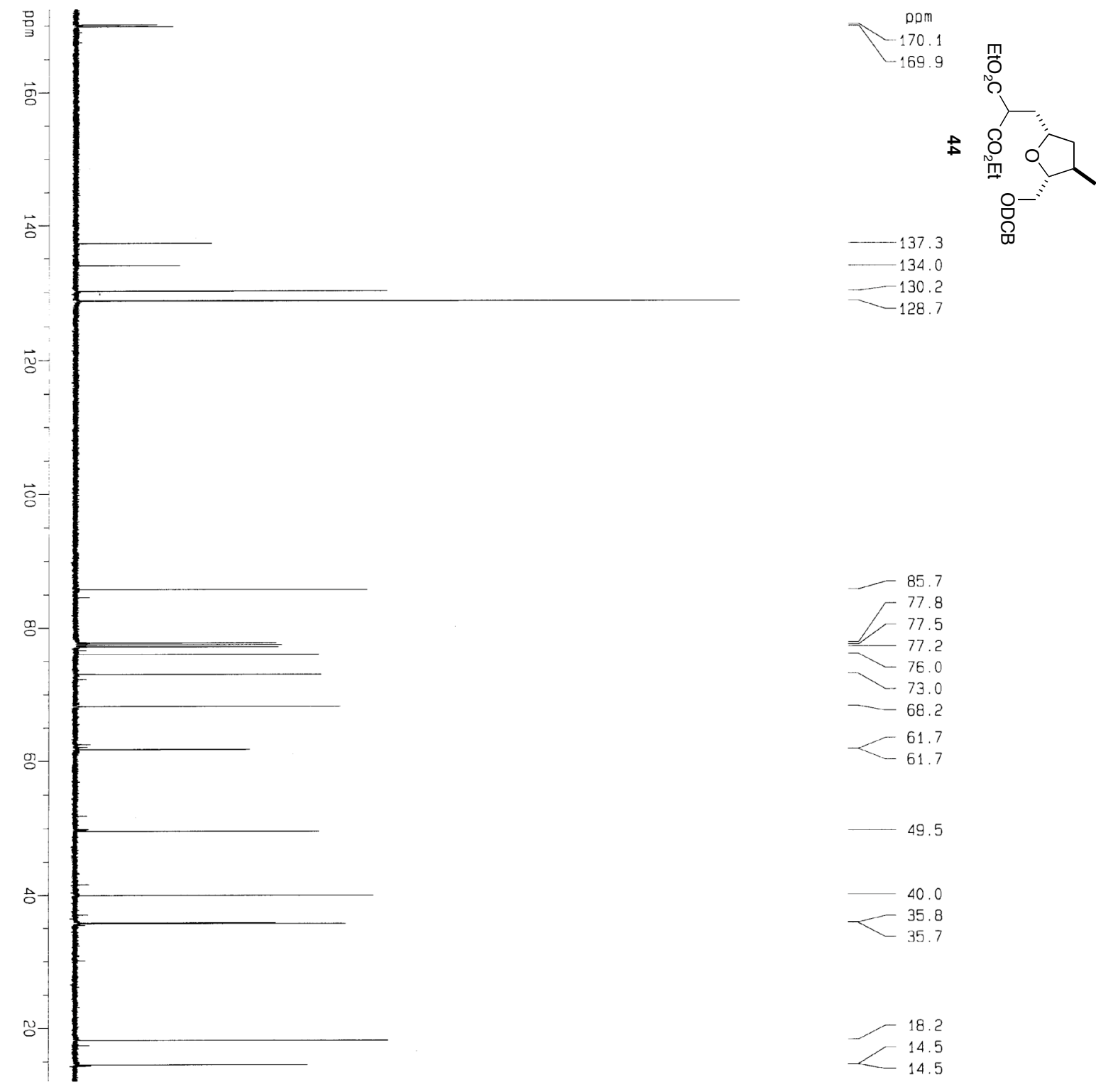

49.5
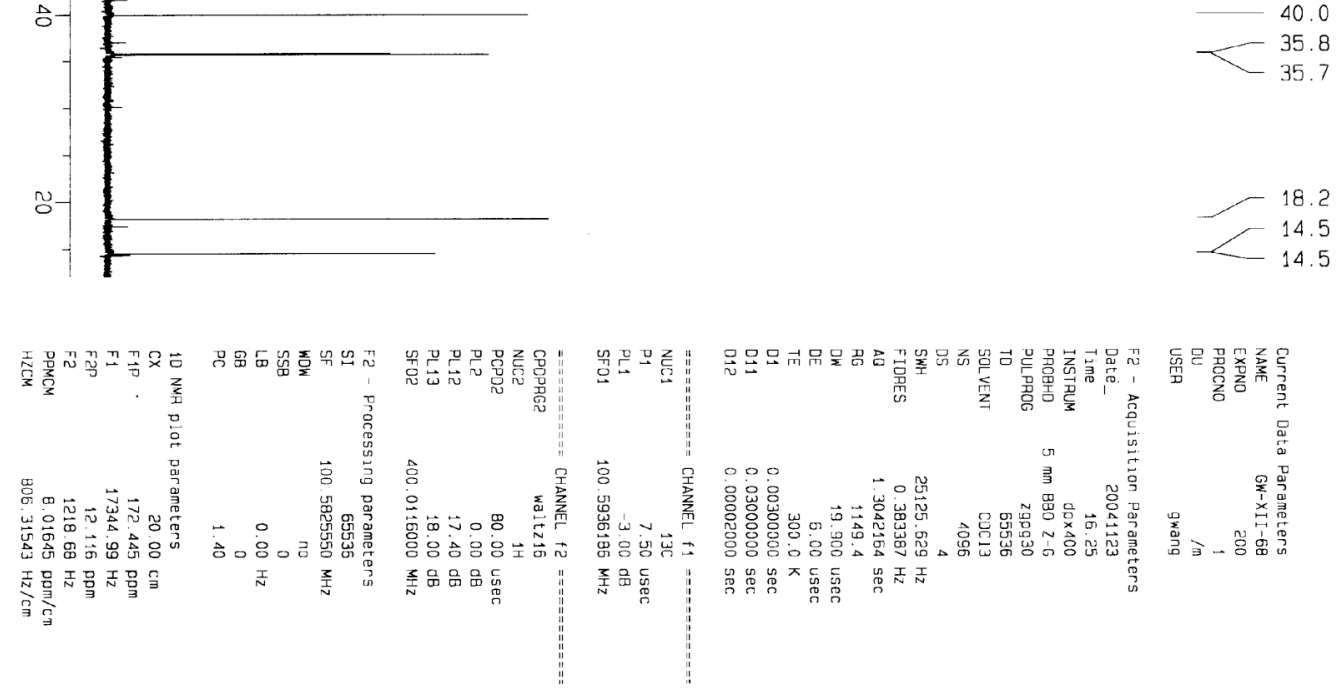


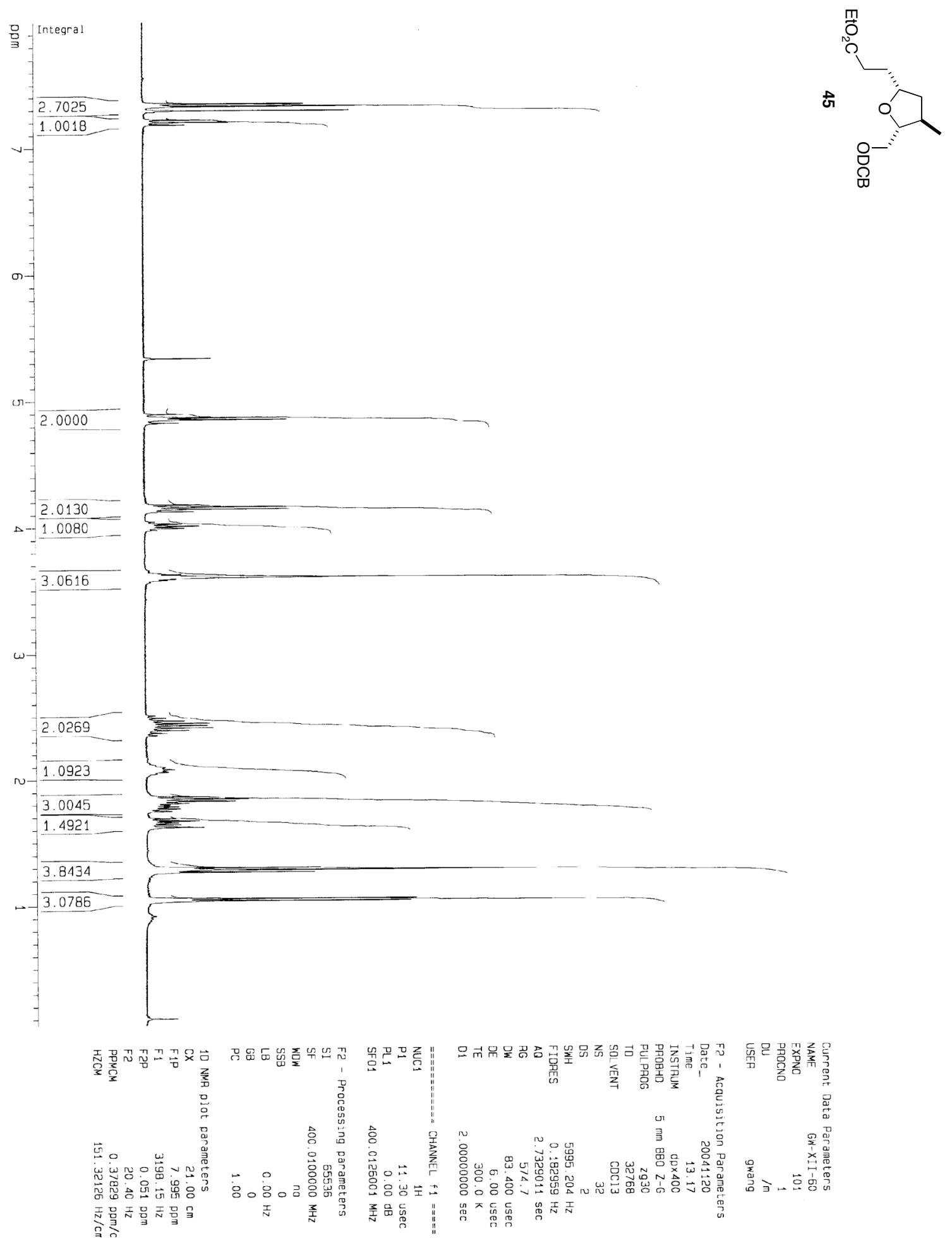




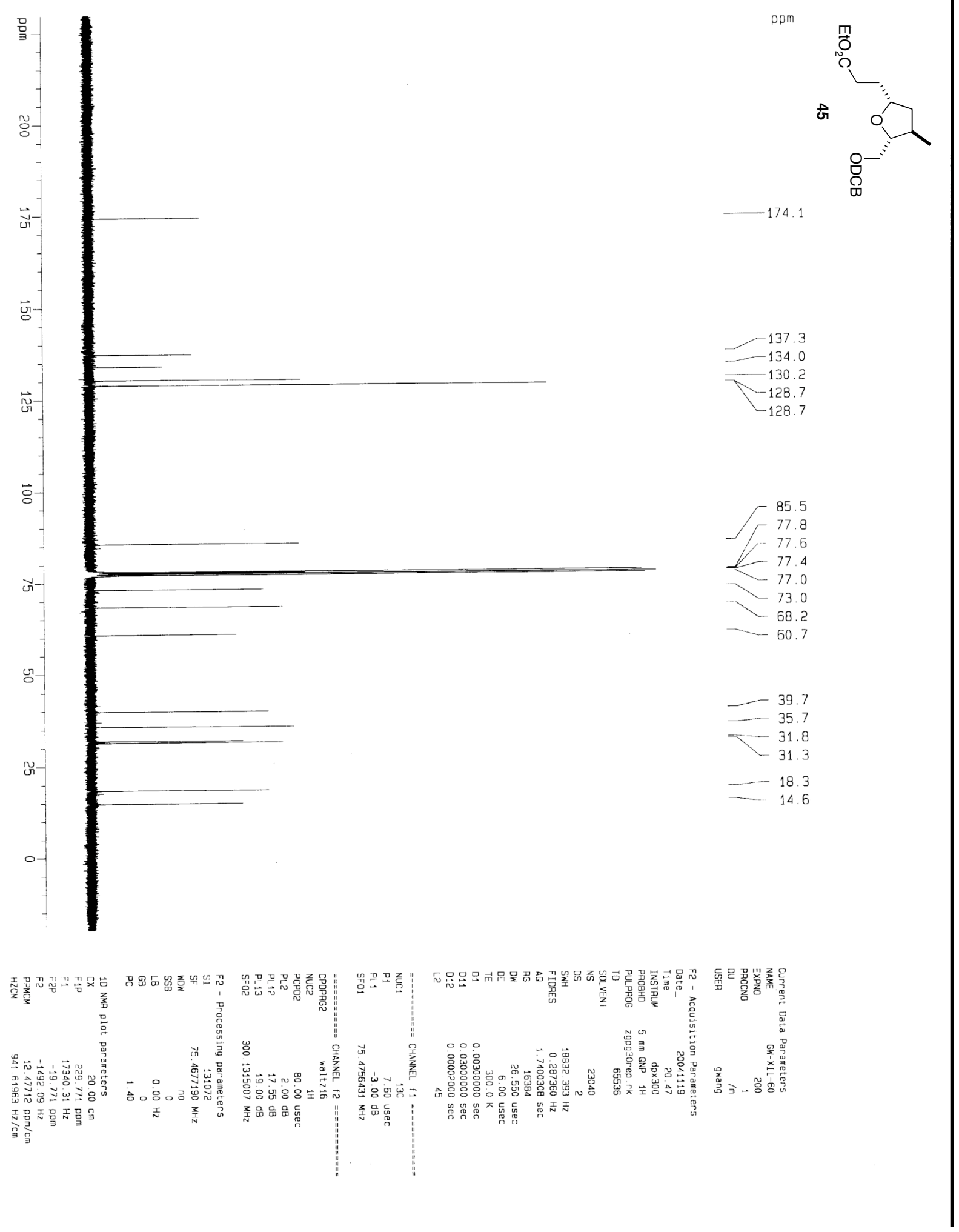



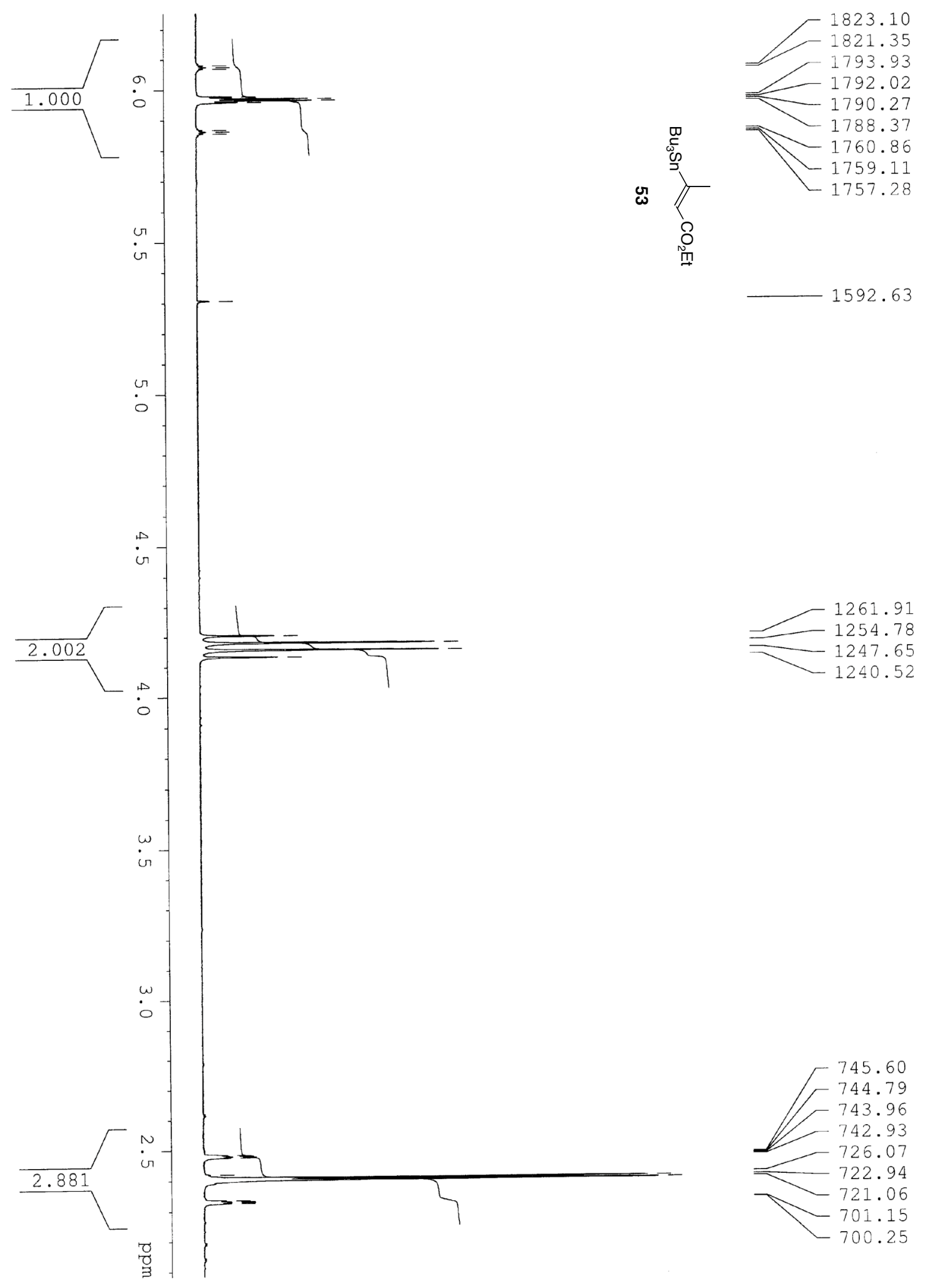

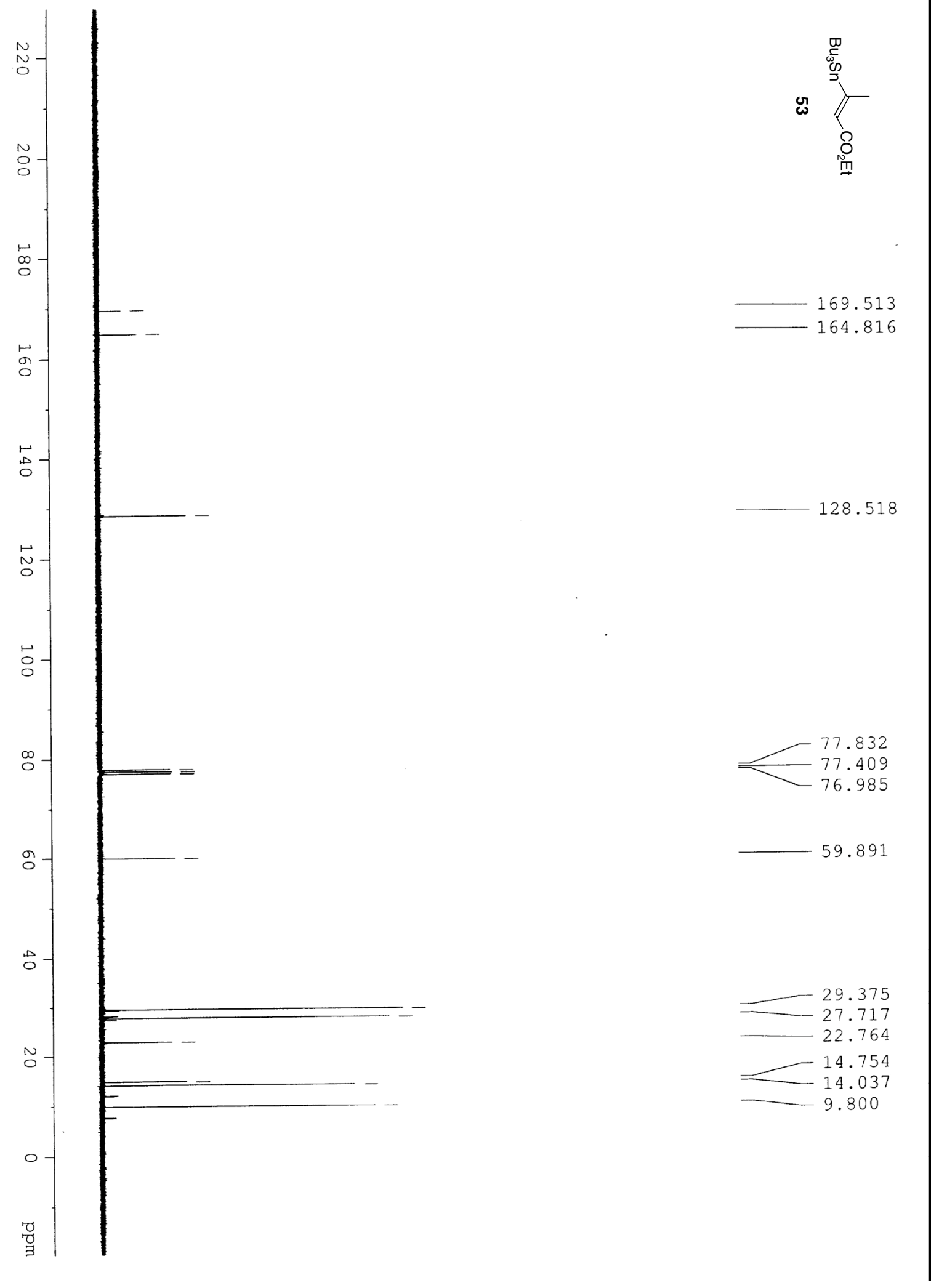


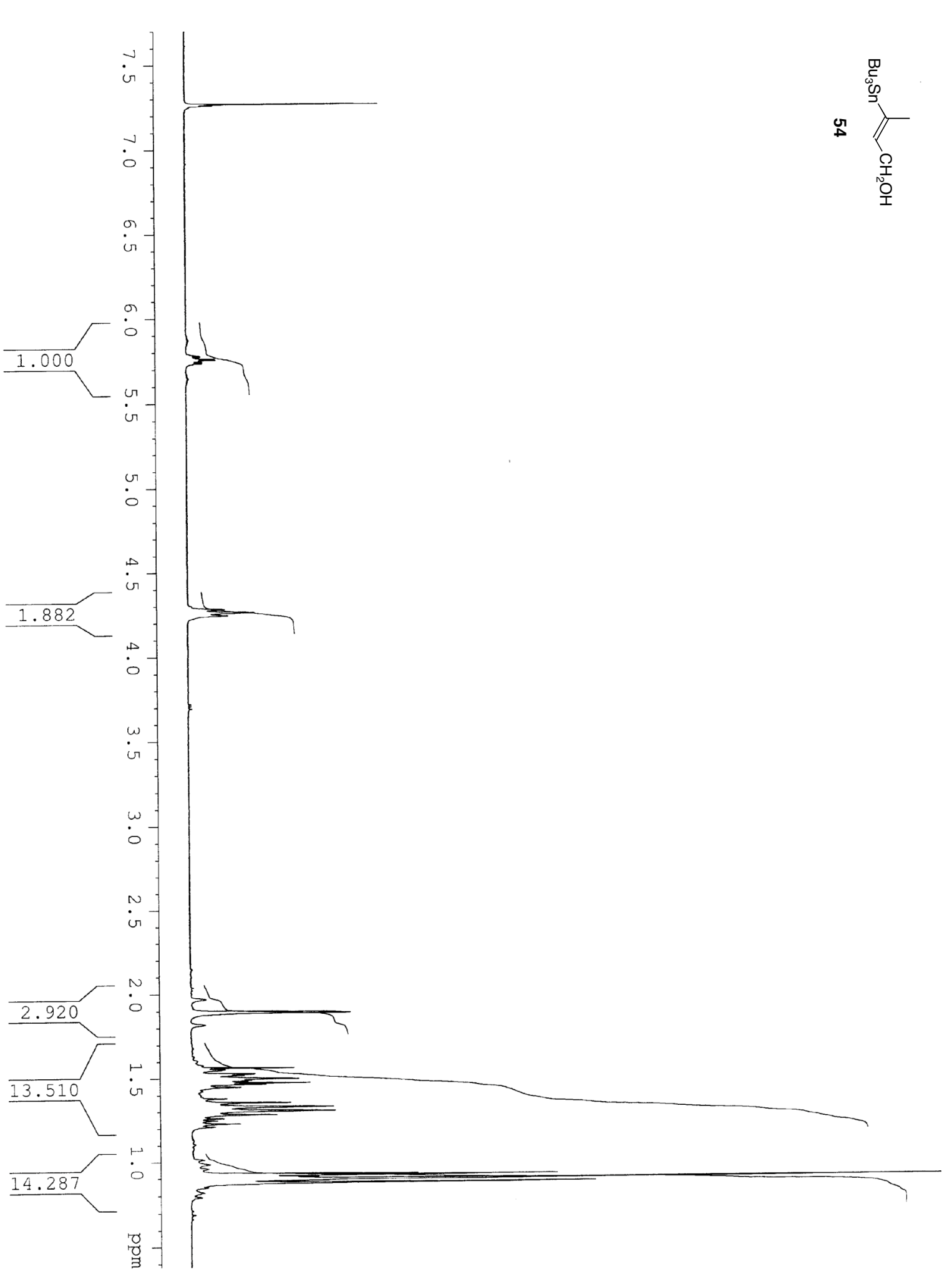




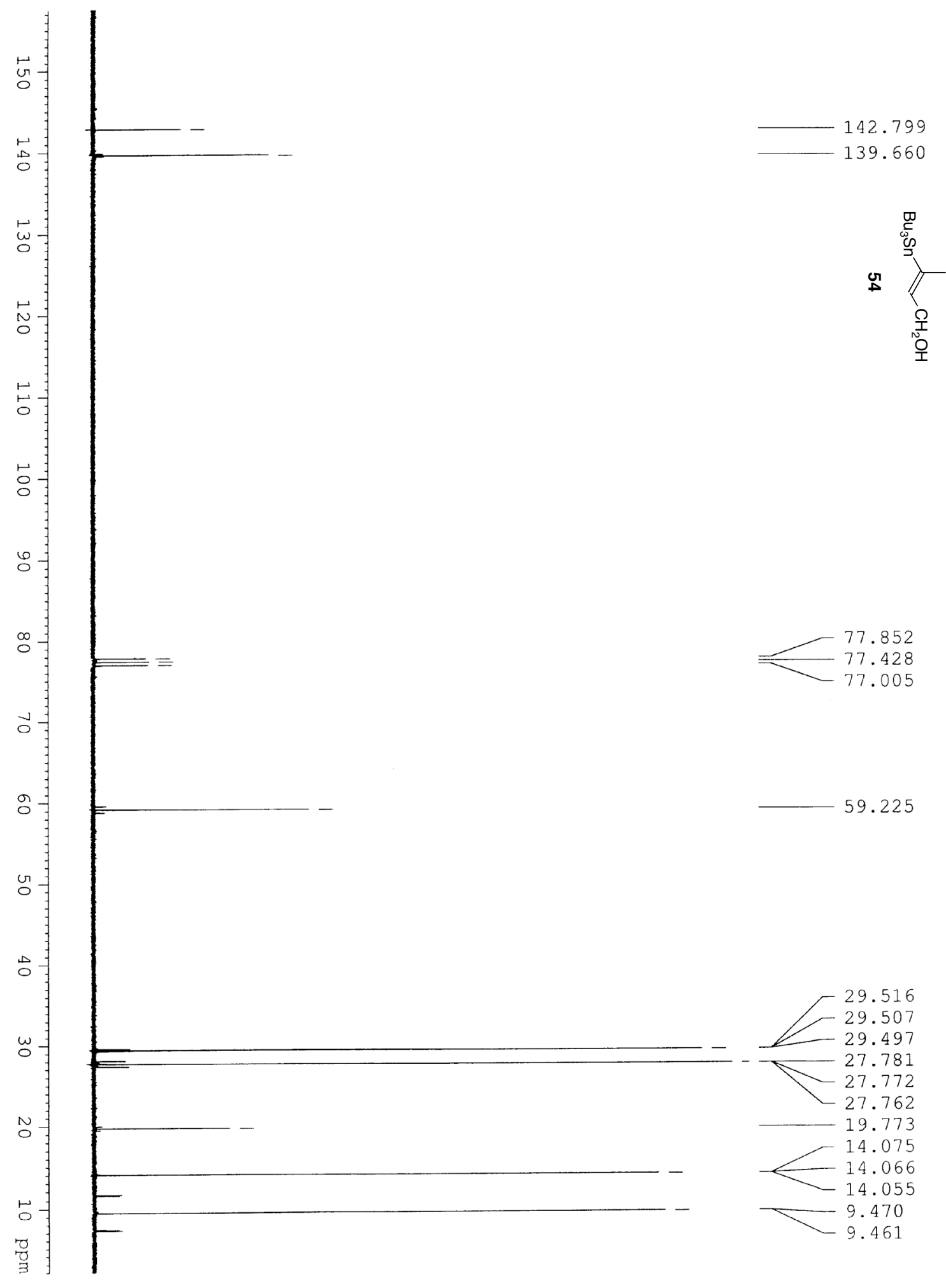




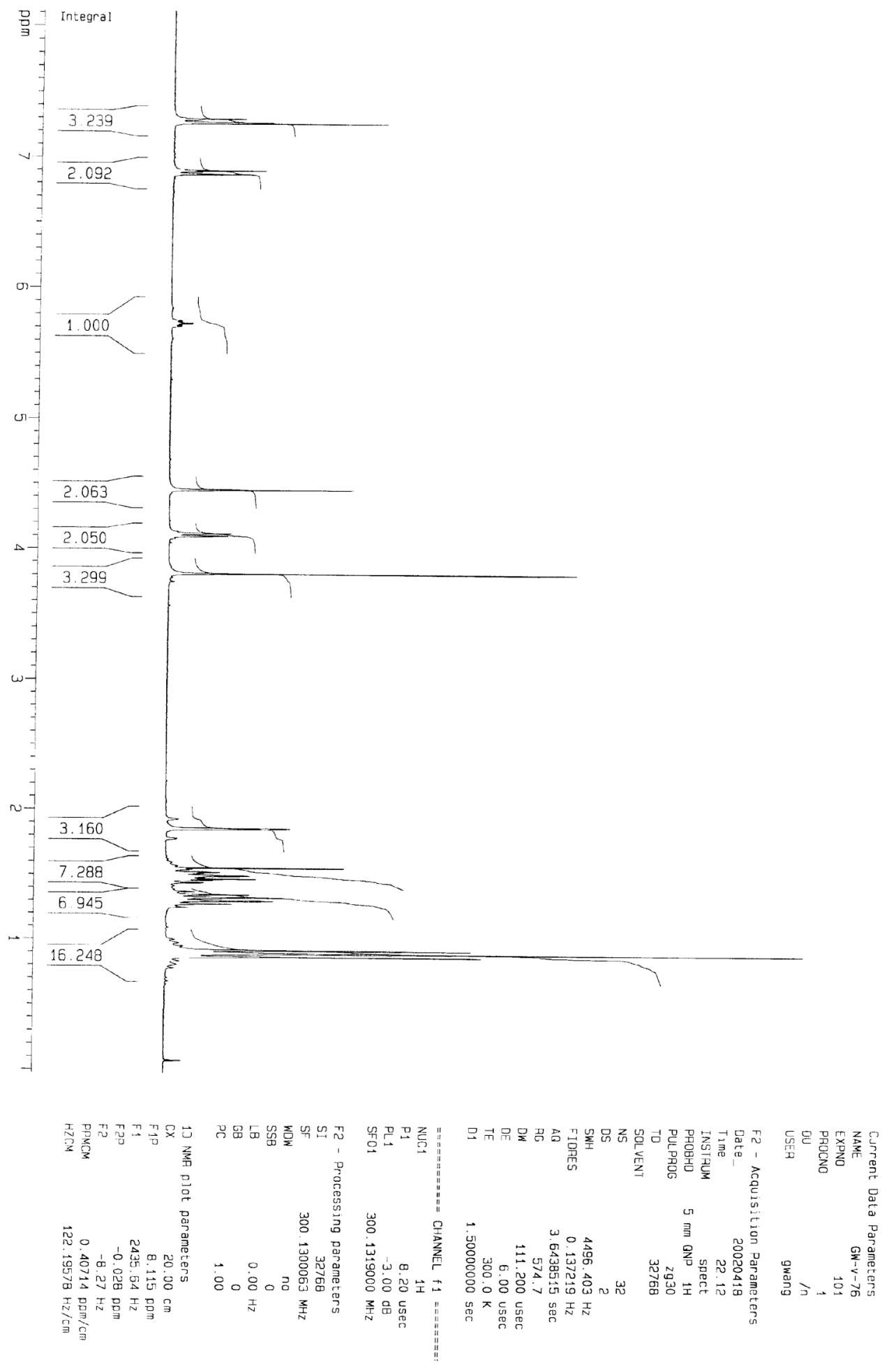




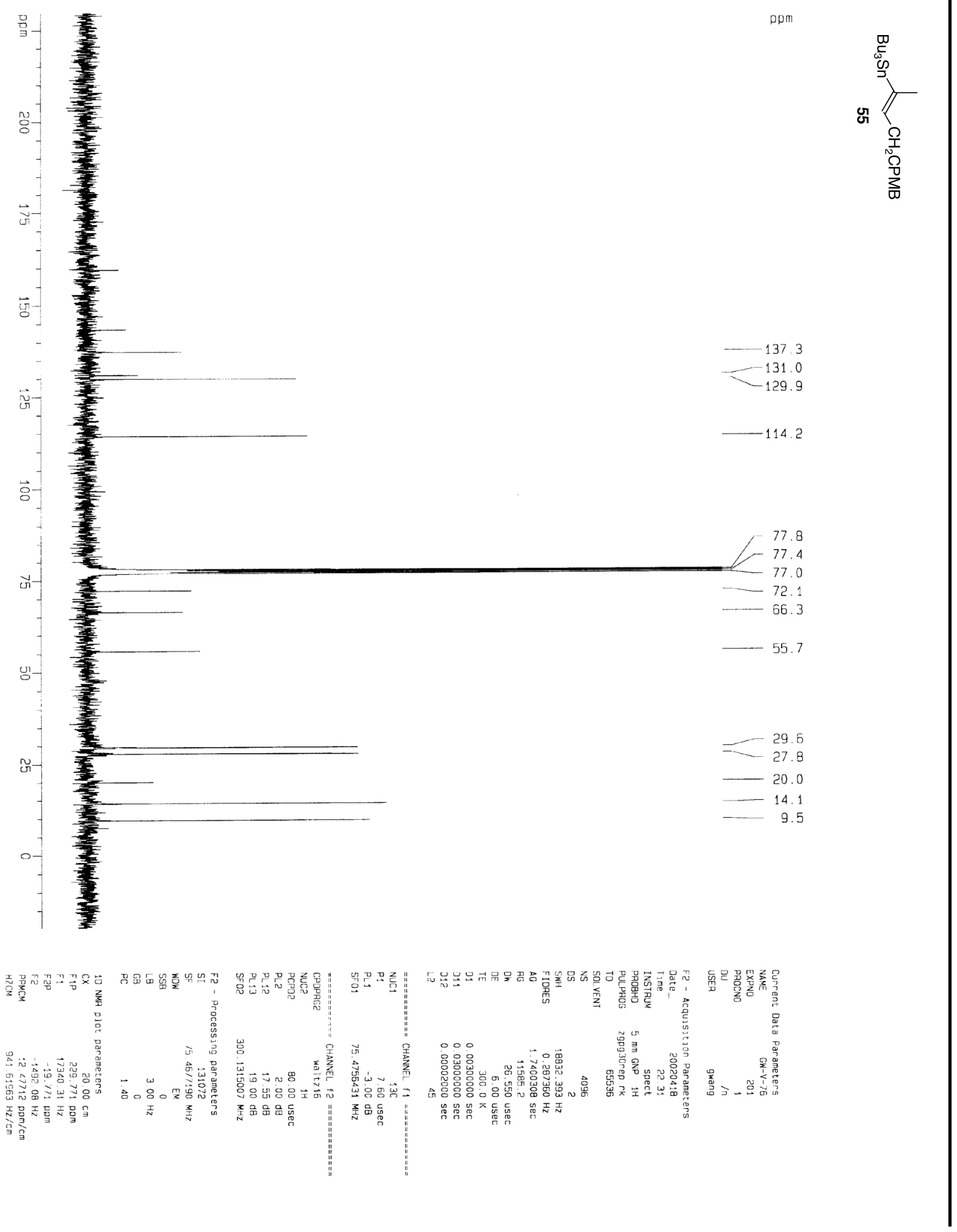




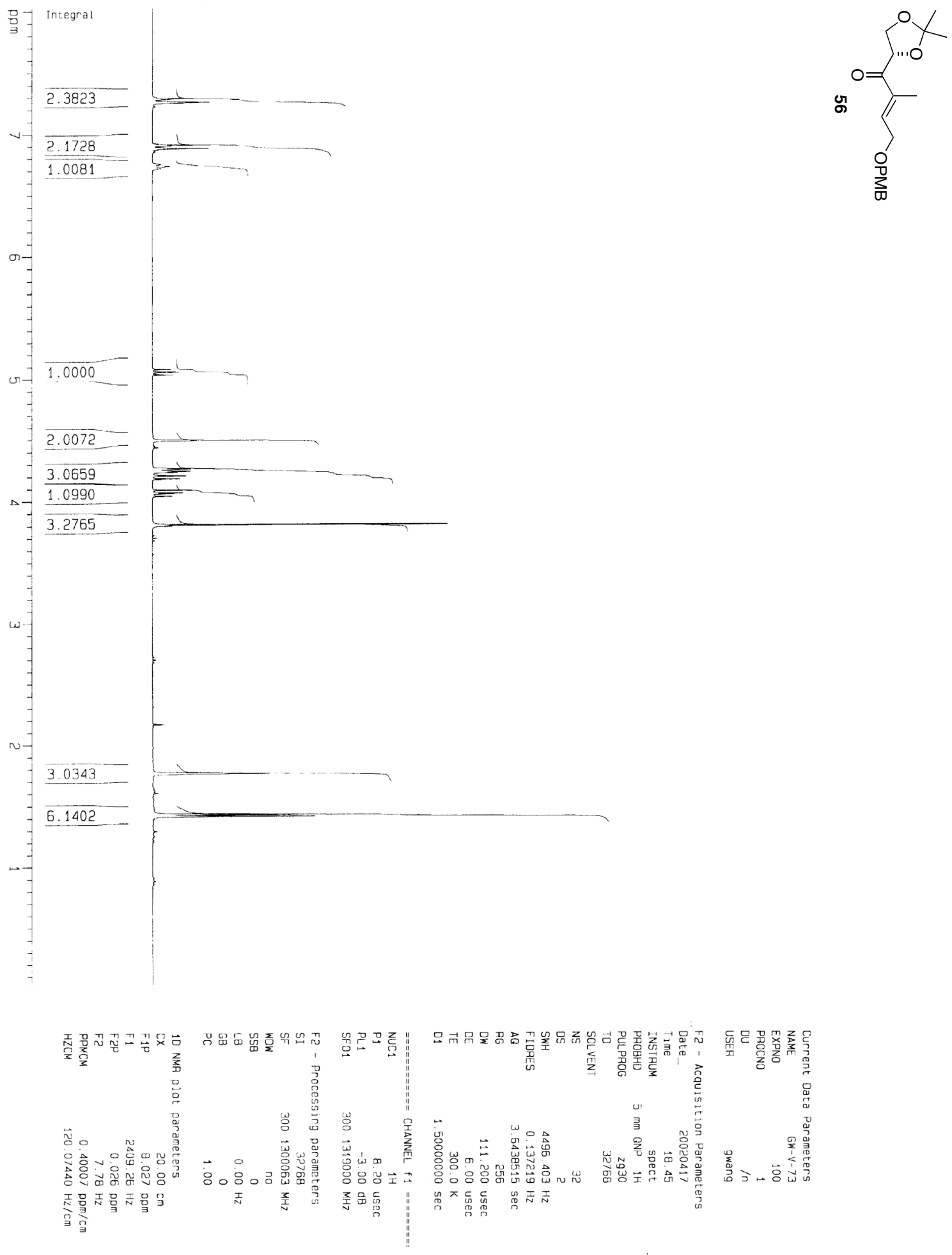




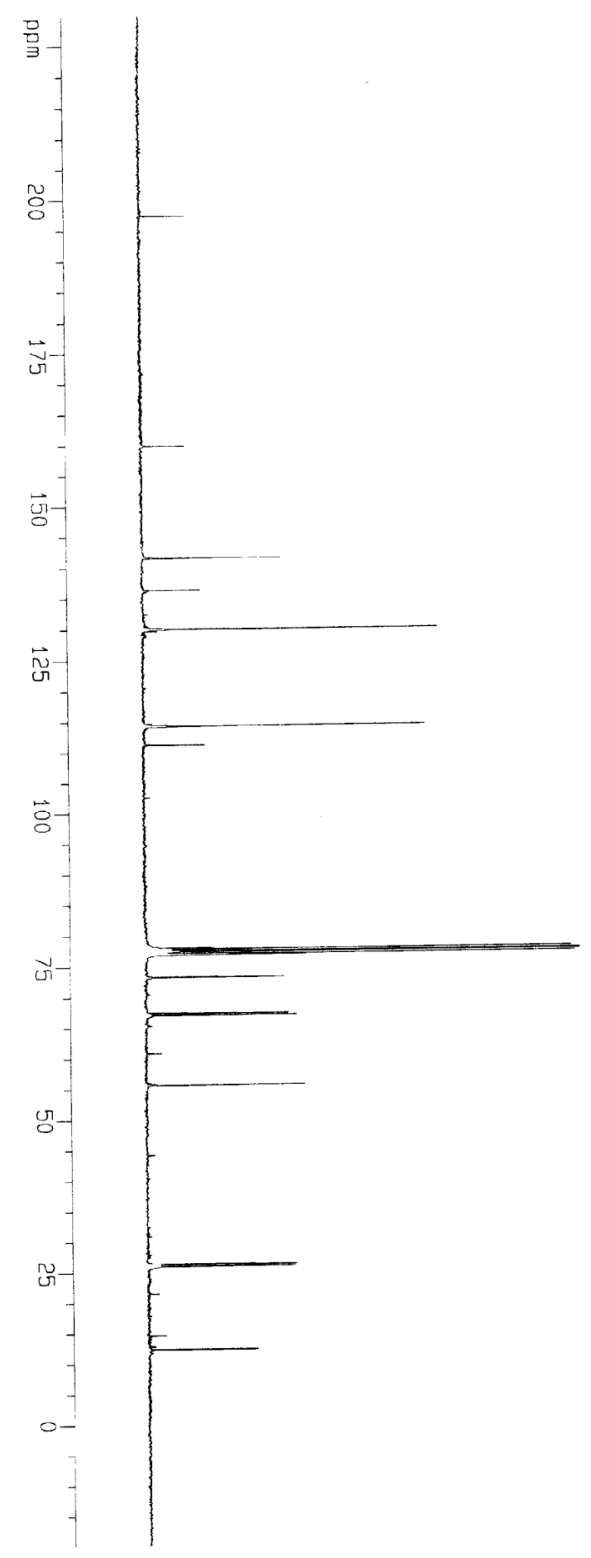

DpM

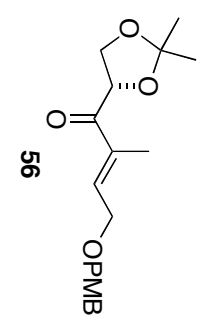

$-1416$

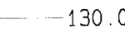

$-114.3$

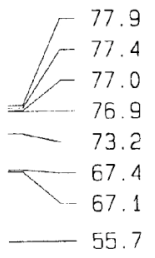

-26.3
$-\quad 26.0$

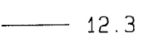

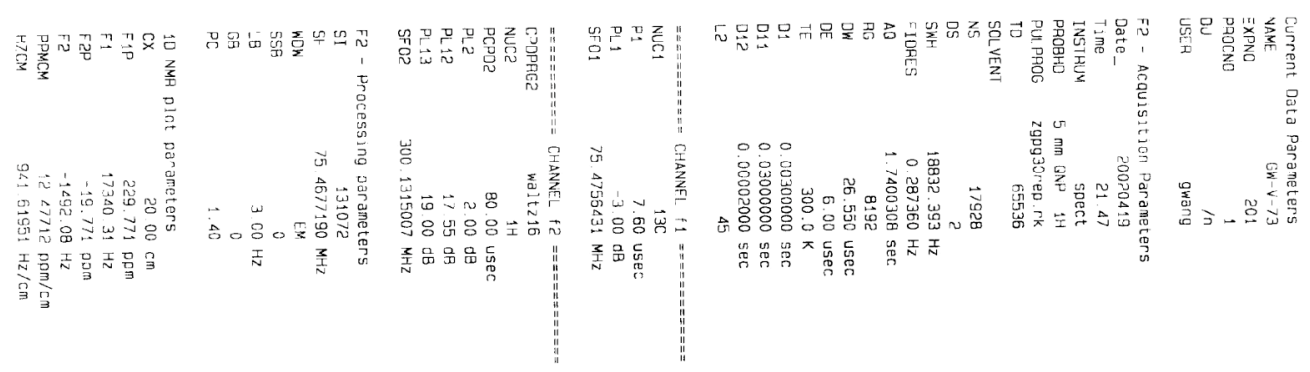




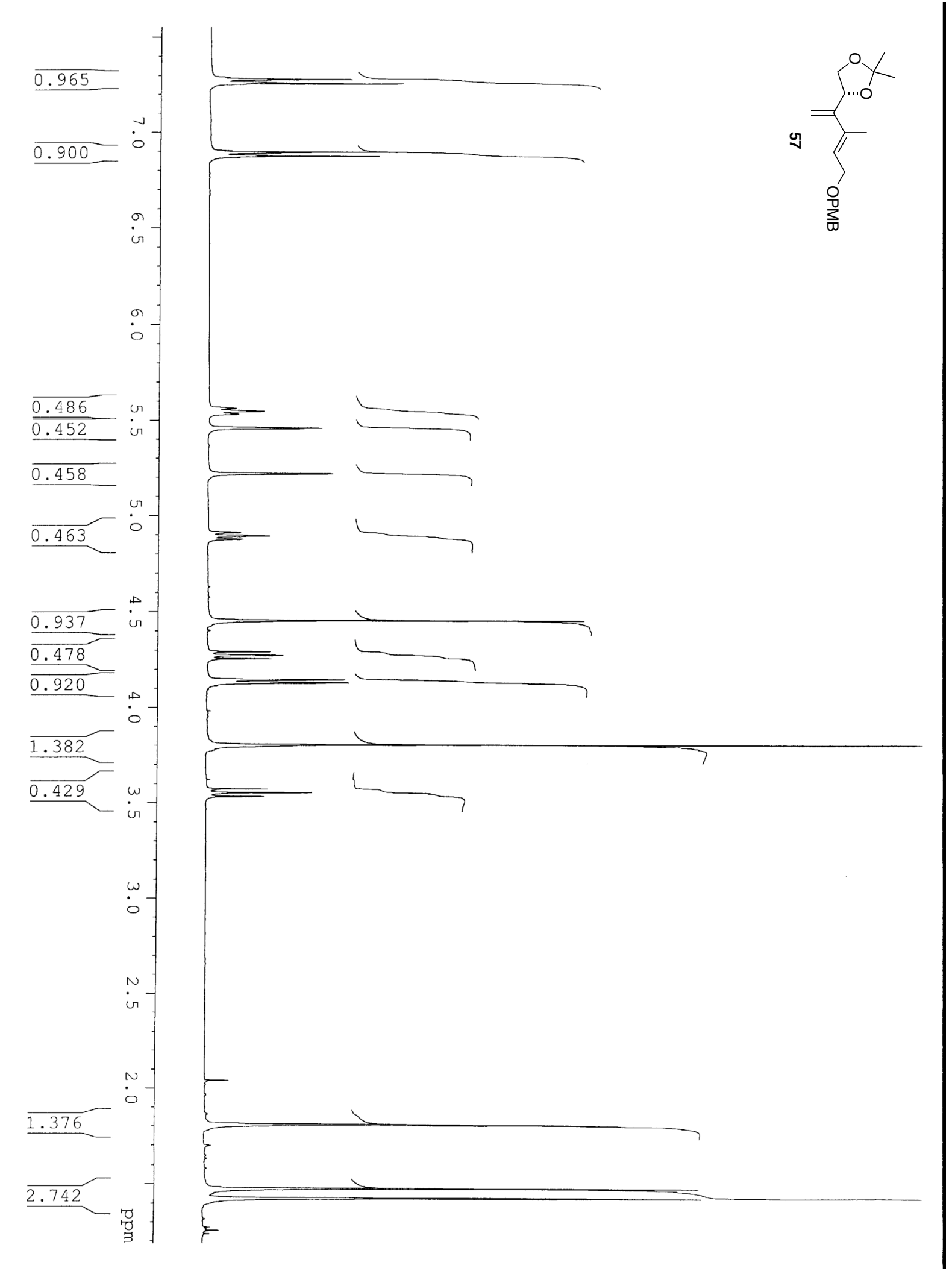



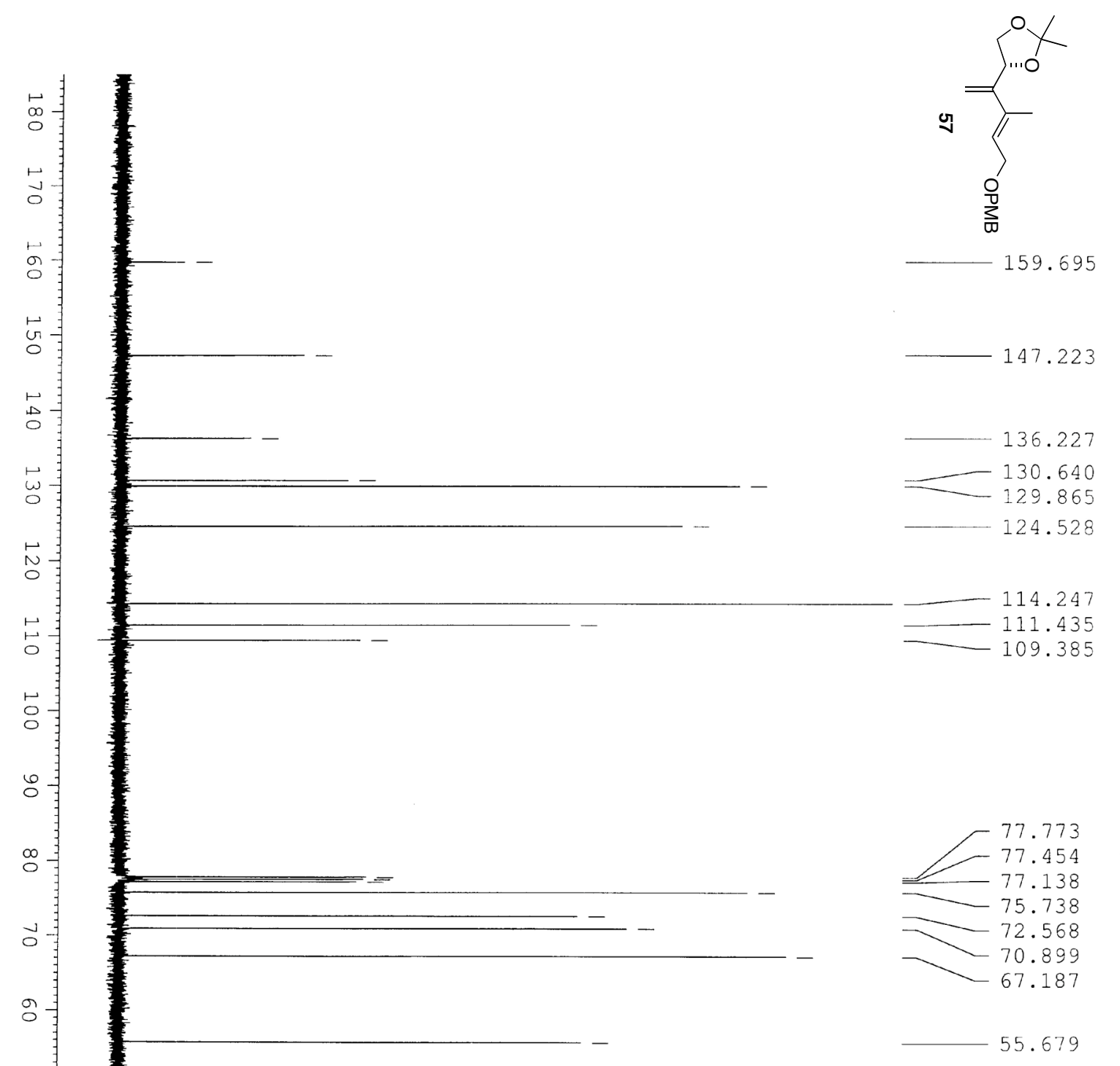

r

$\stackrel{\circ}{\circ}$

w

N

○

总
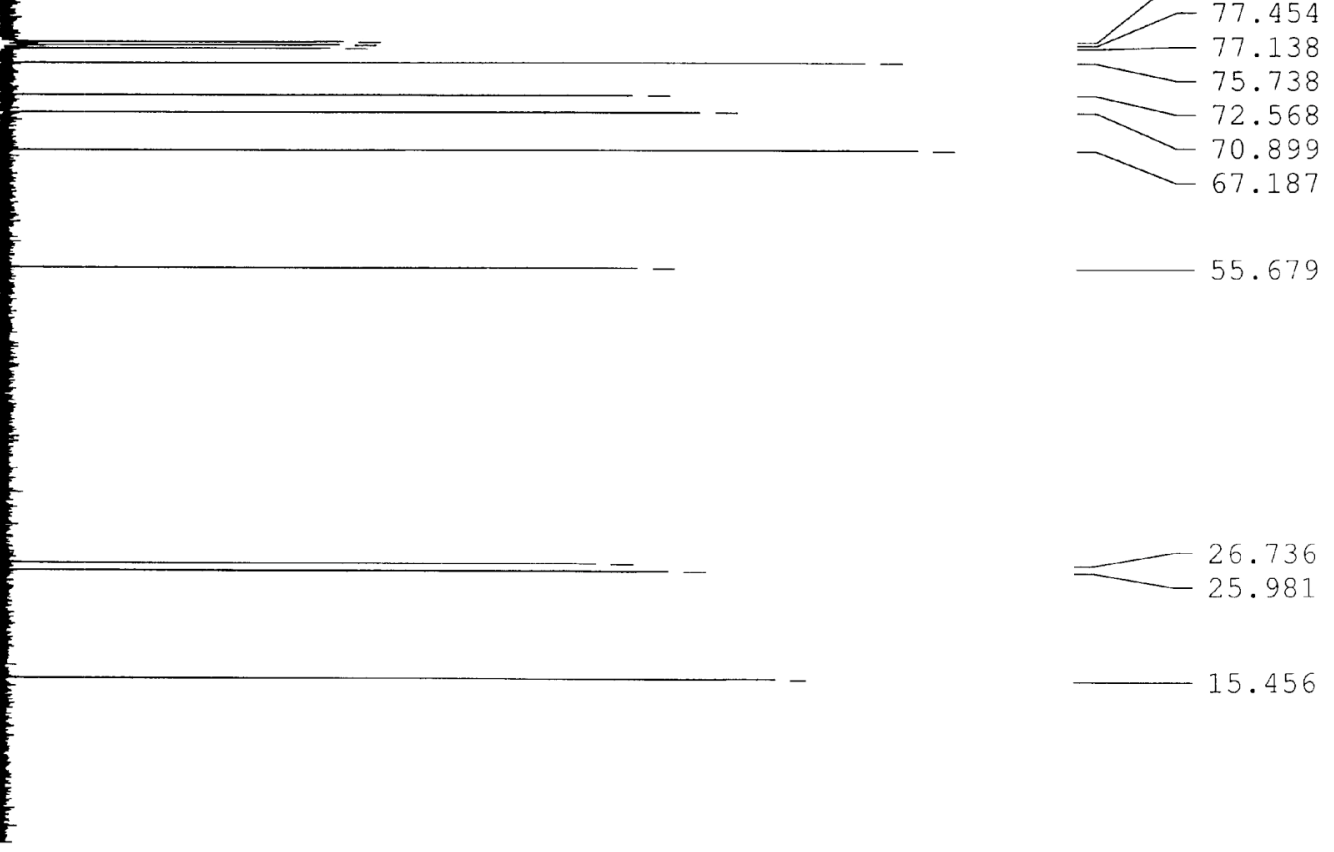


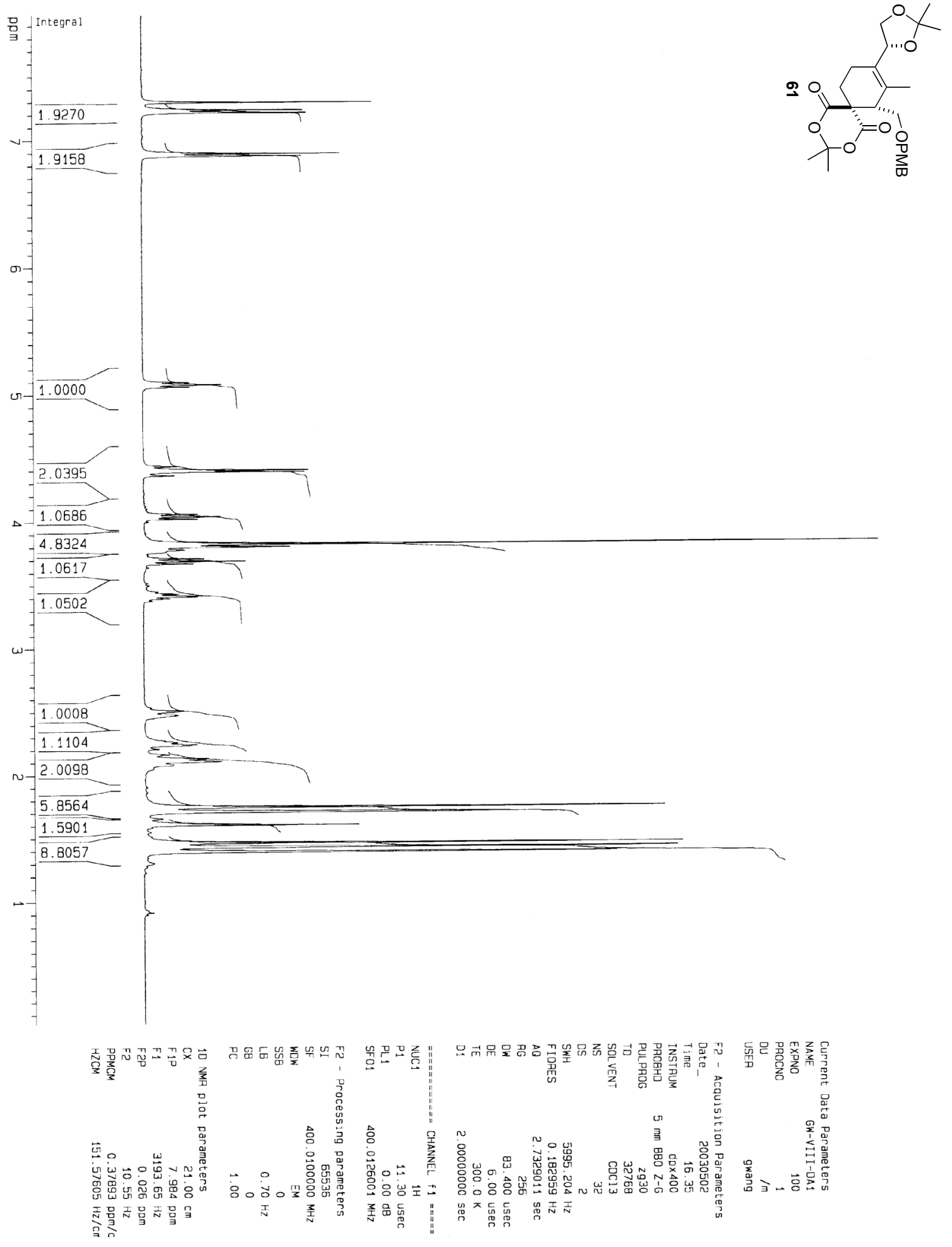




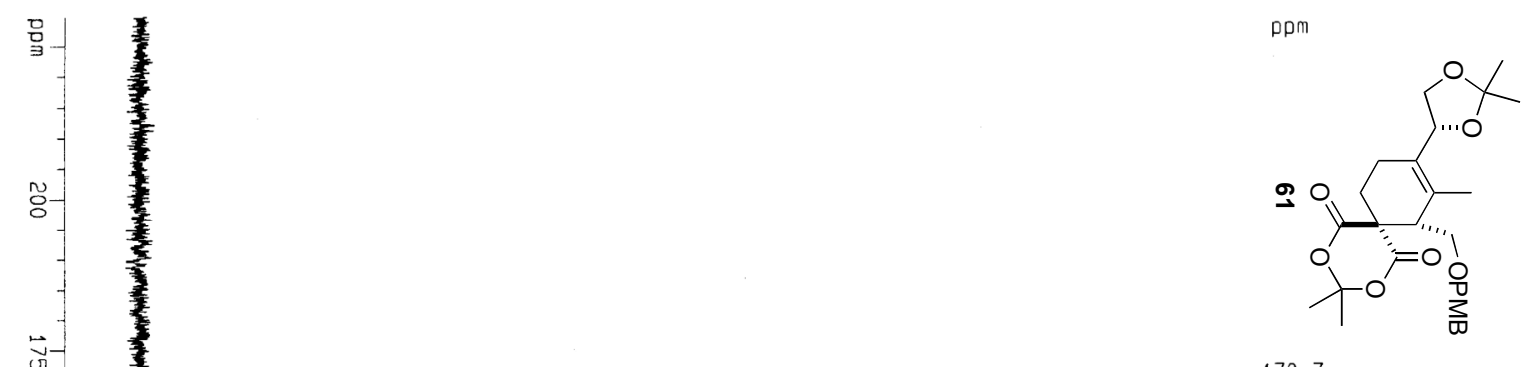

빙

N
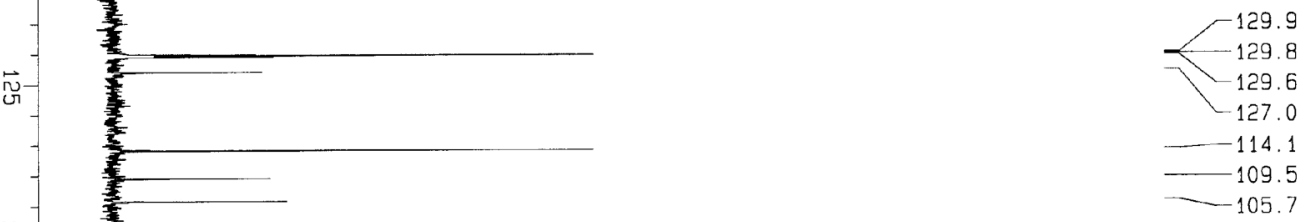

응.

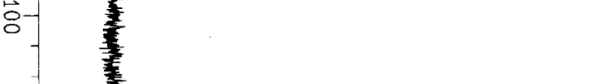

$-105.7$
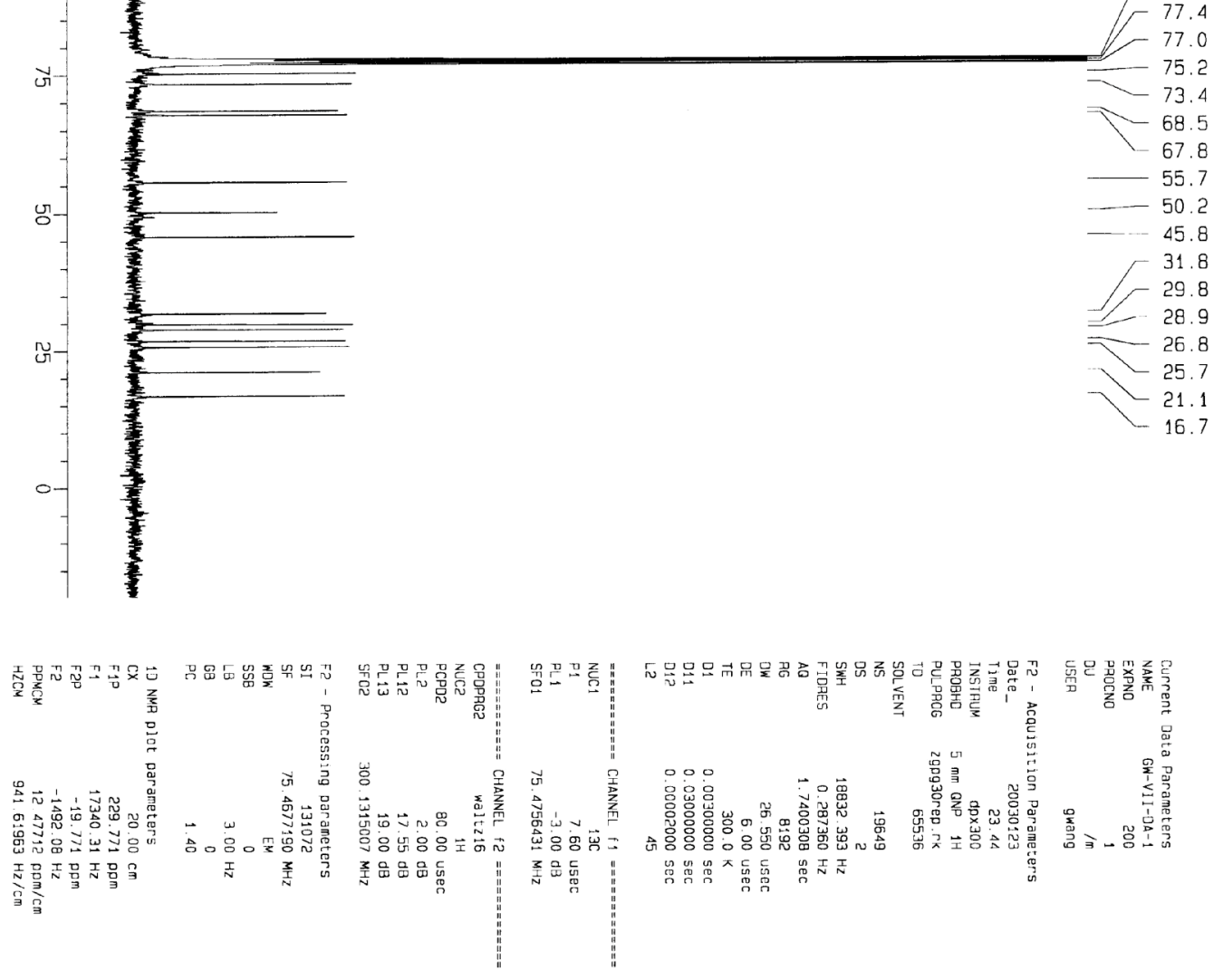


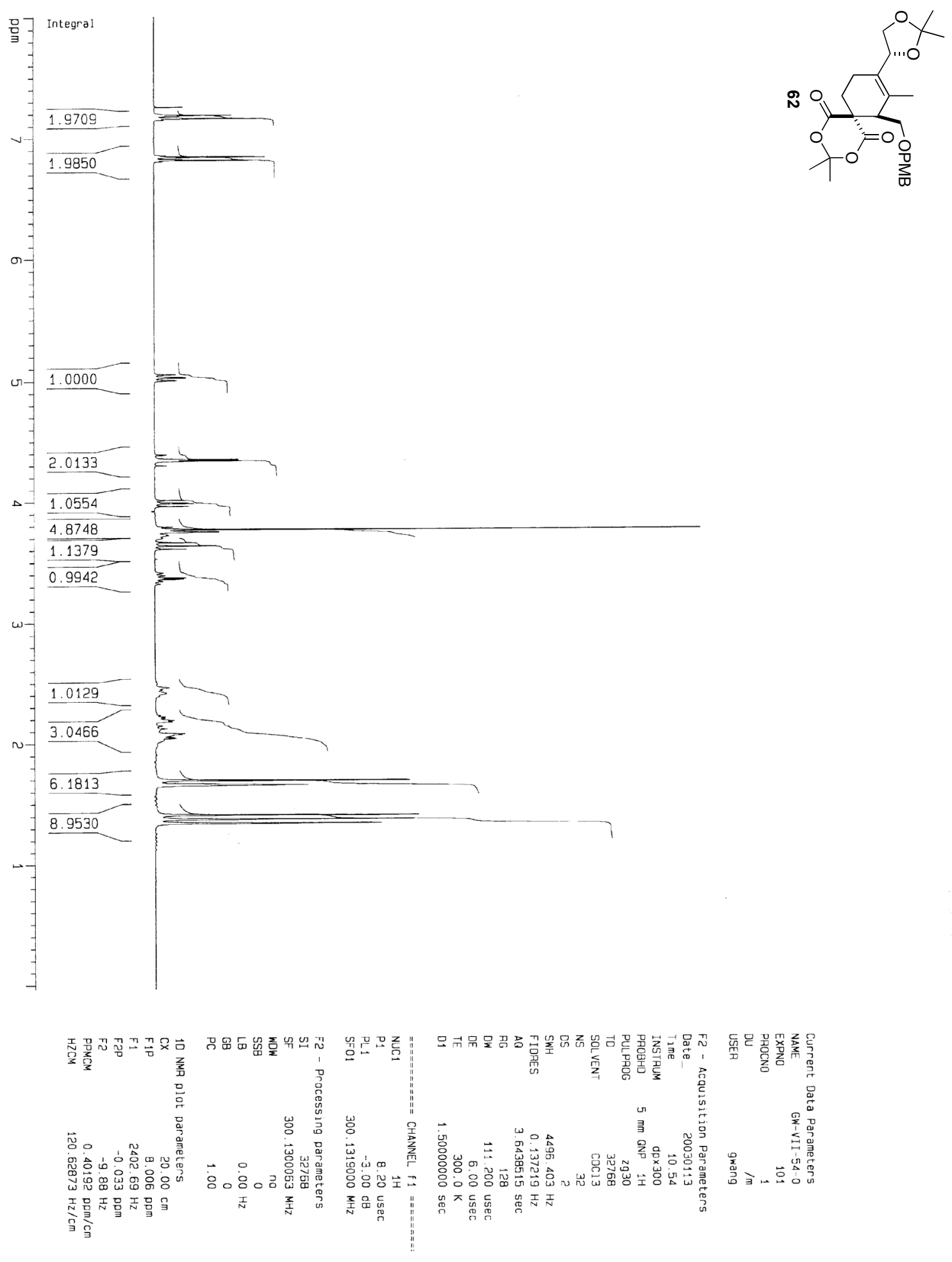




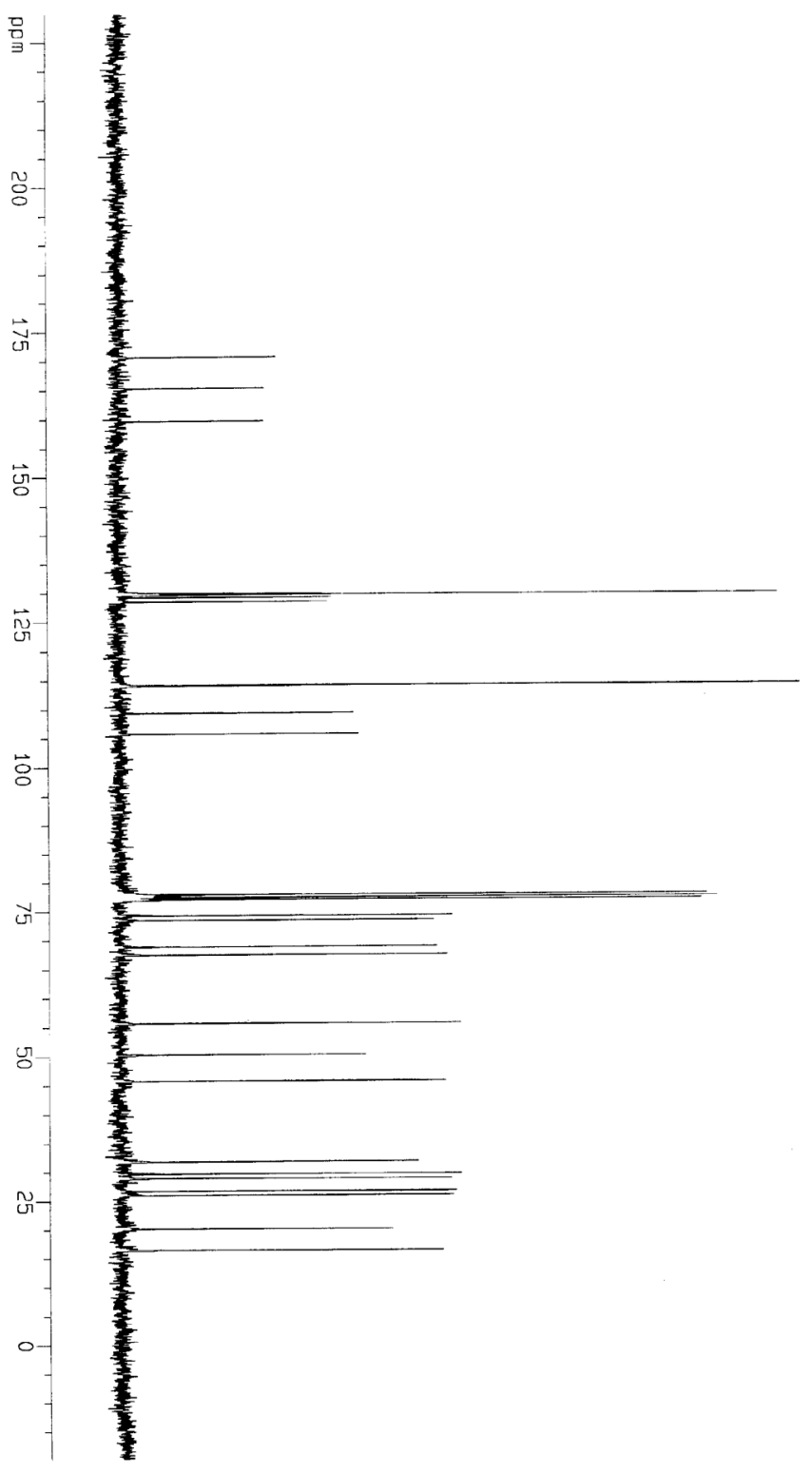

$p p m$
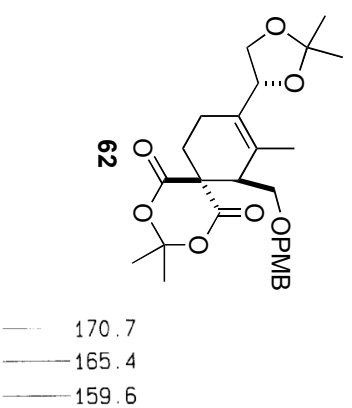

159.6
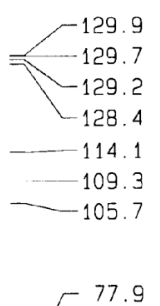

77.5
-77.0

$-74.3$

$-73.5$

$-68.8$

$-67.4$

- 55.6

- 50.3

$-45.7$

- 31.8

29.7

$-28.9$

$-26.7$

$-26.0$

20.1
-16.4

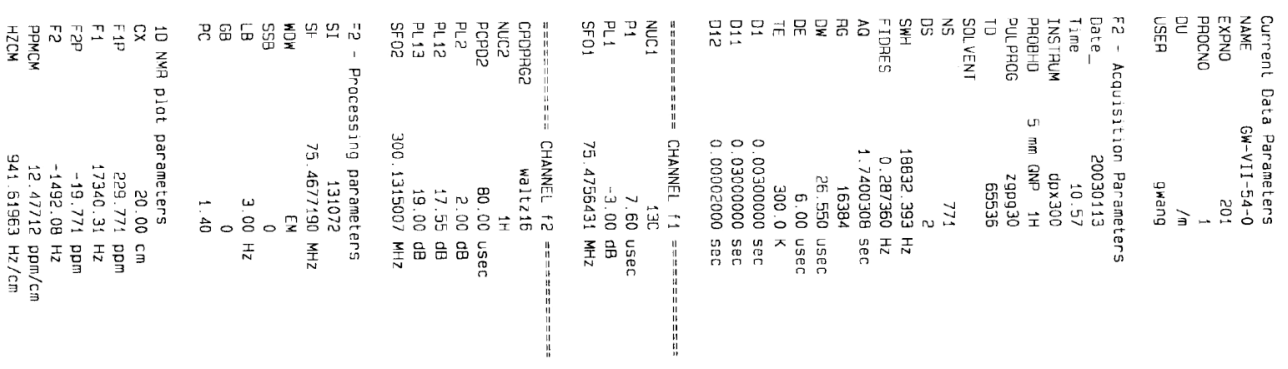




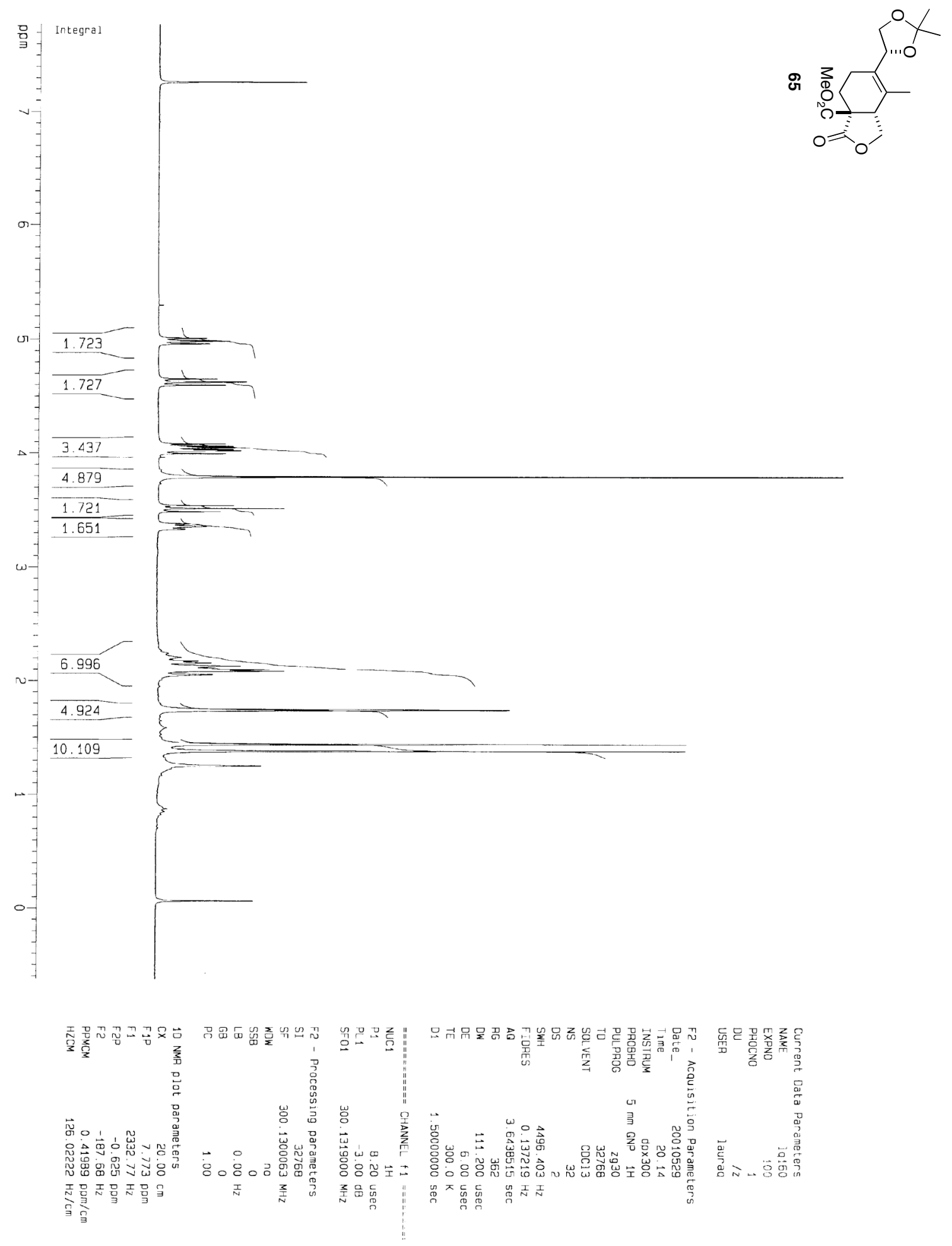



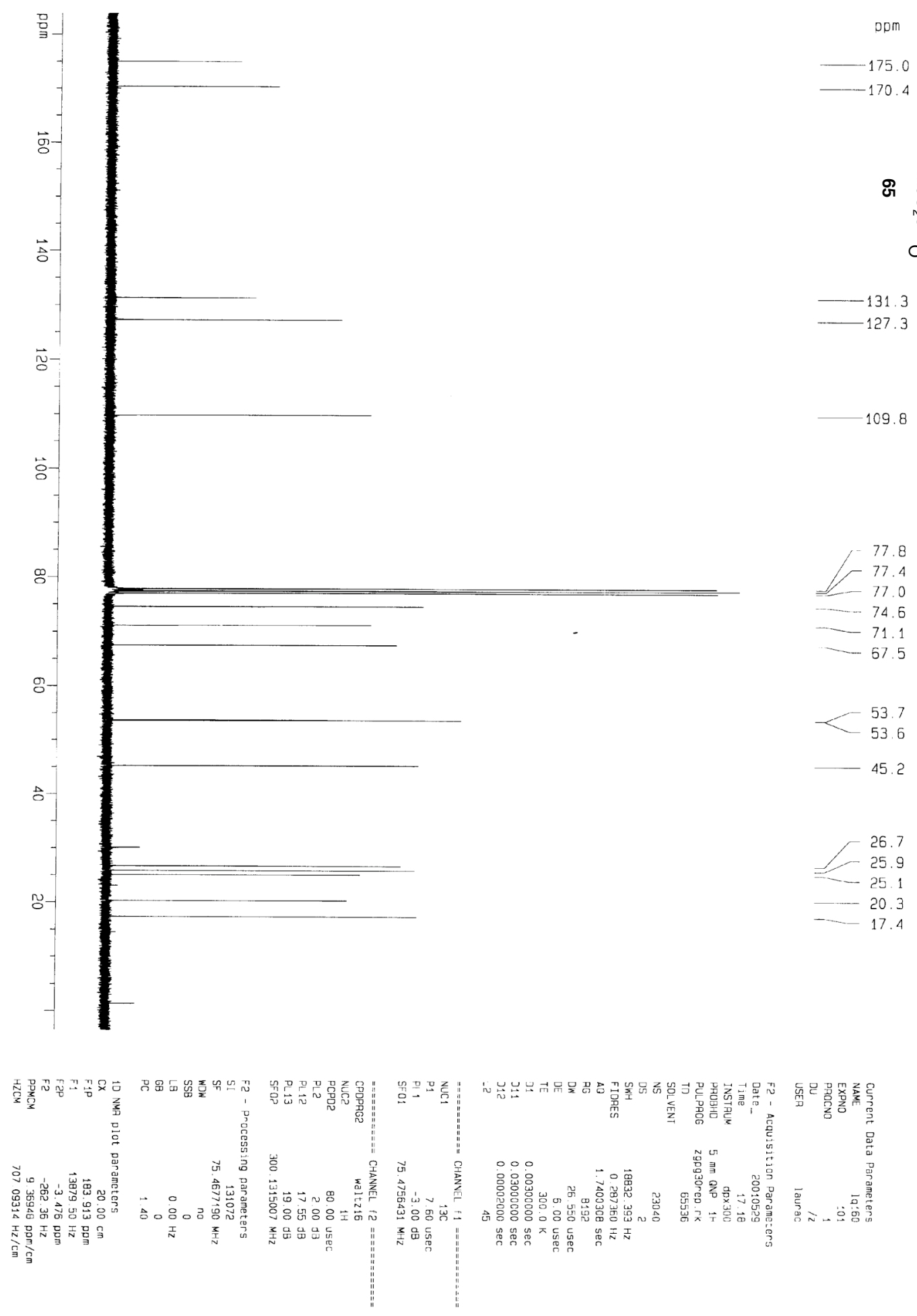


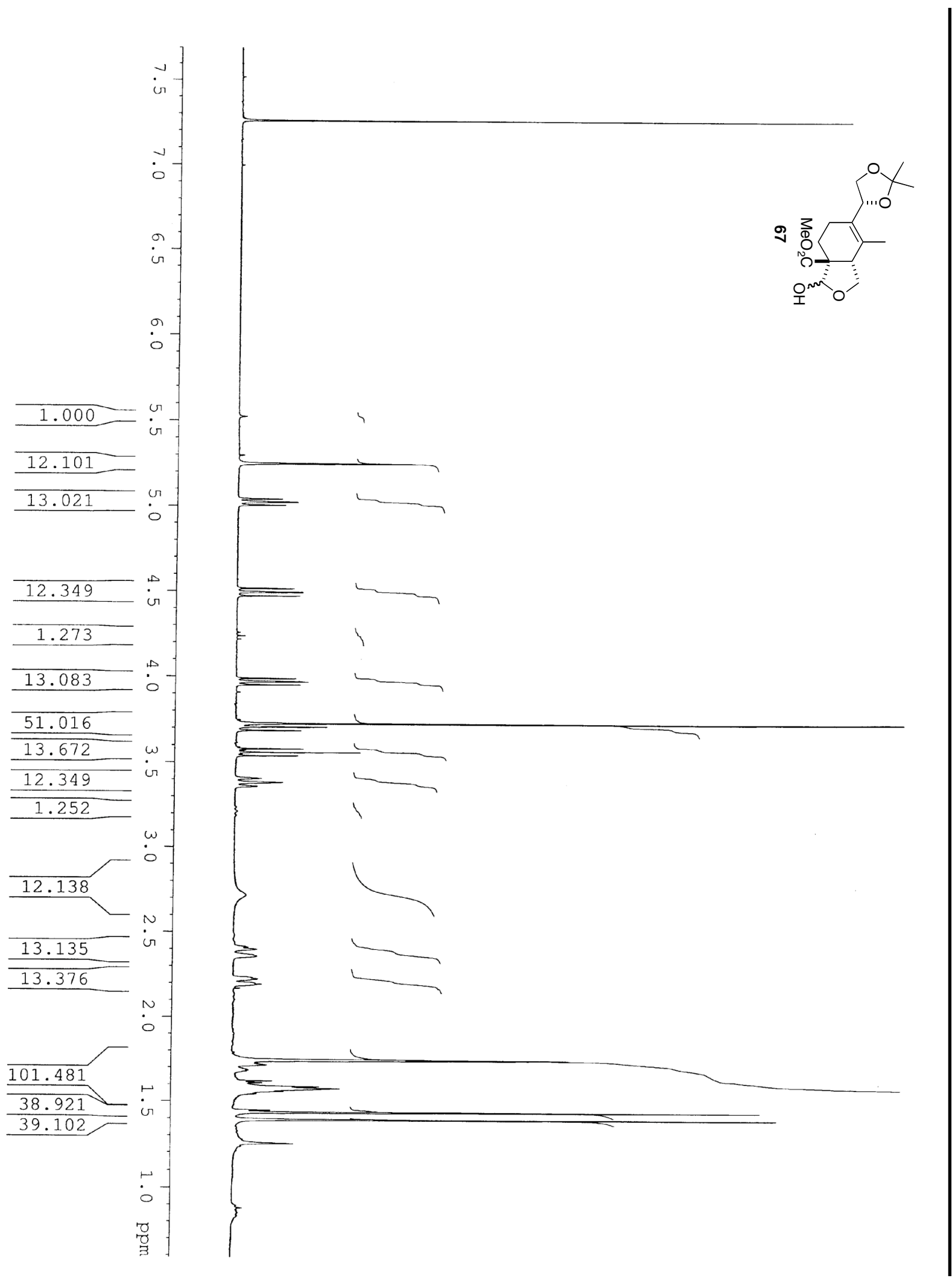



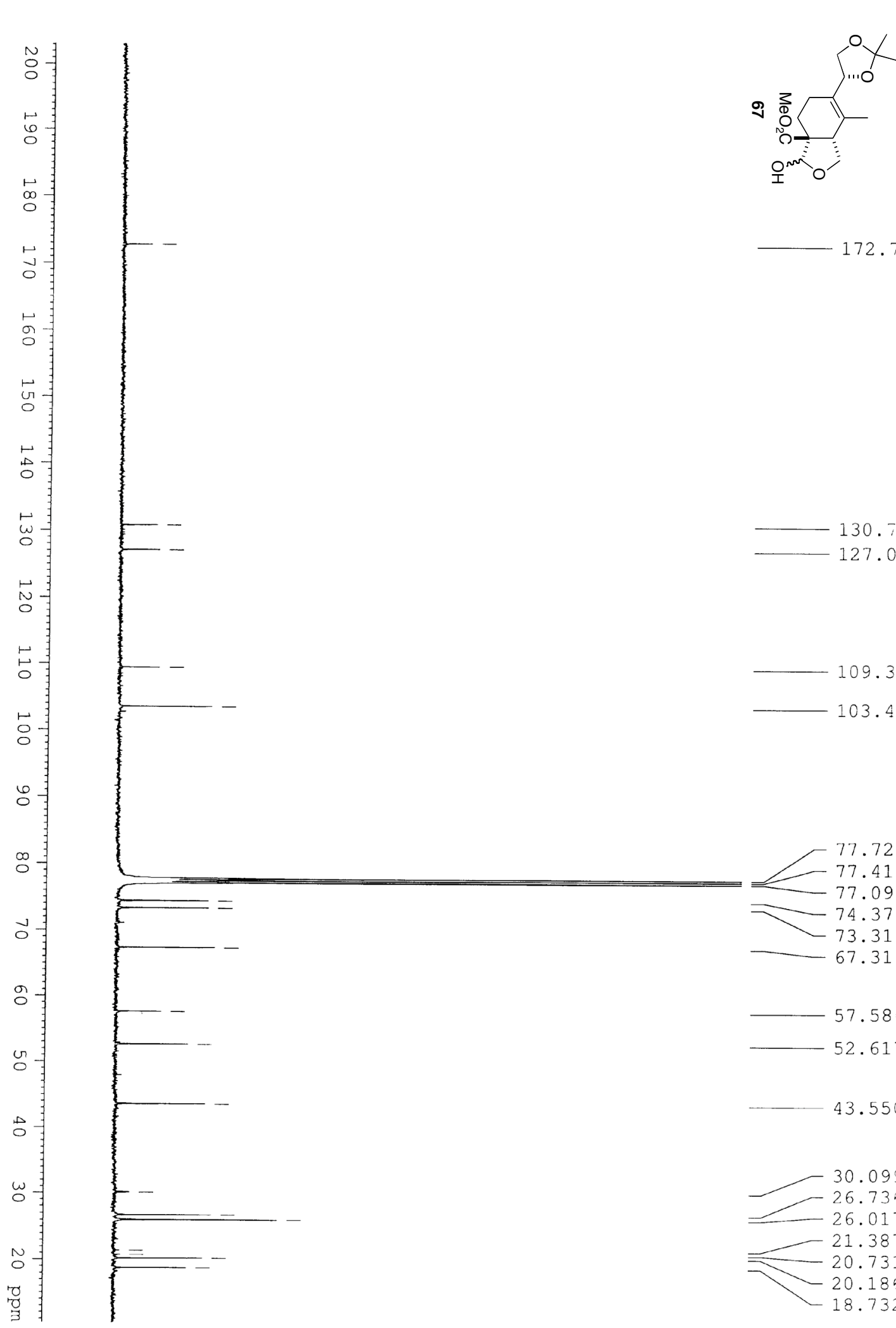

$-172.75 \equiv$

$130.7 \div$ 127.063

- 109.36:

$-103.462$

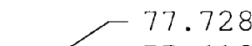

77.410

77.093

74.378

73.317

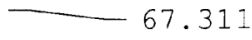

$-57.585$

52.617

$-43.550$

30.099 26.735

26.017

21.387

$=20.731$

$-20.186$

$-18.732$ 


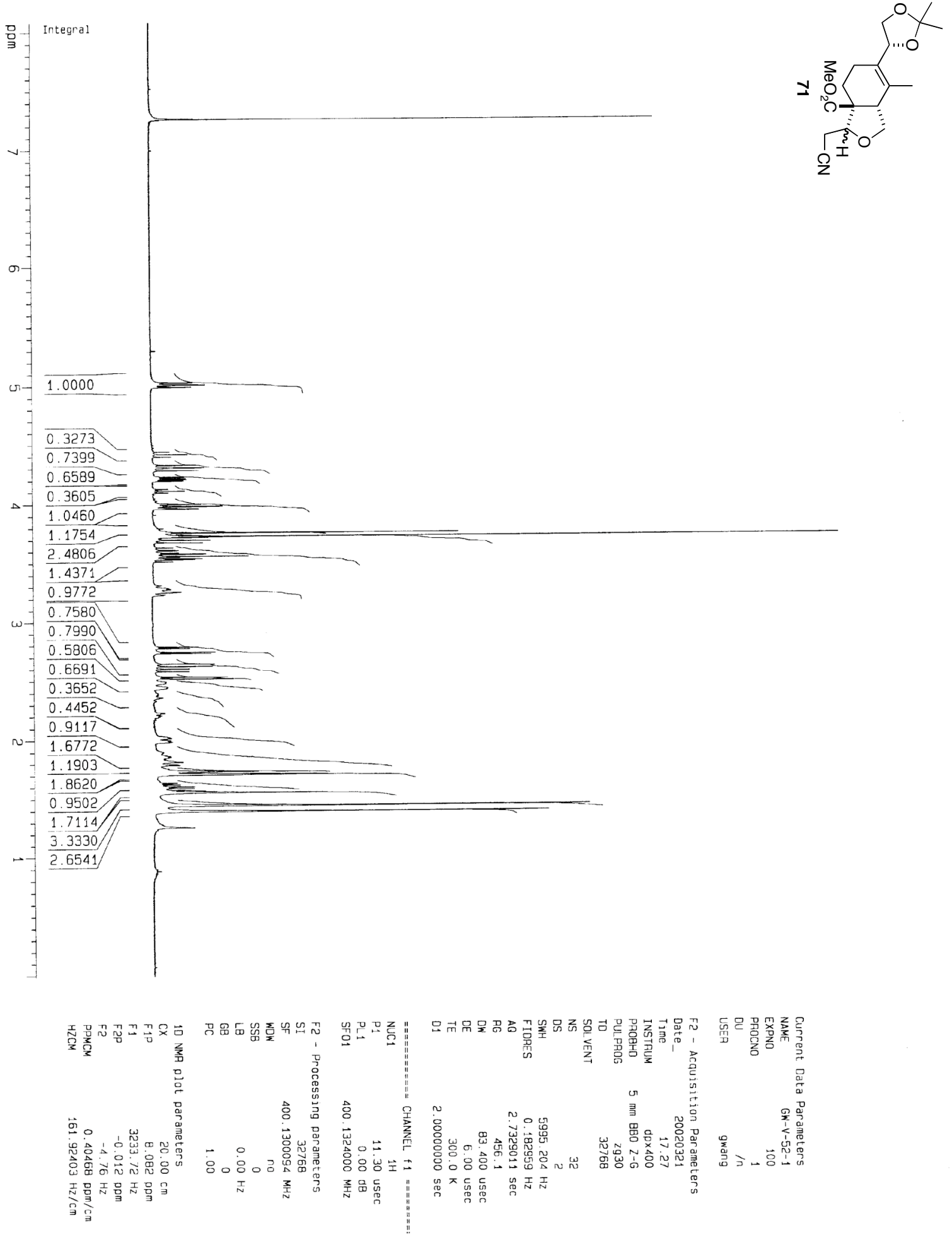




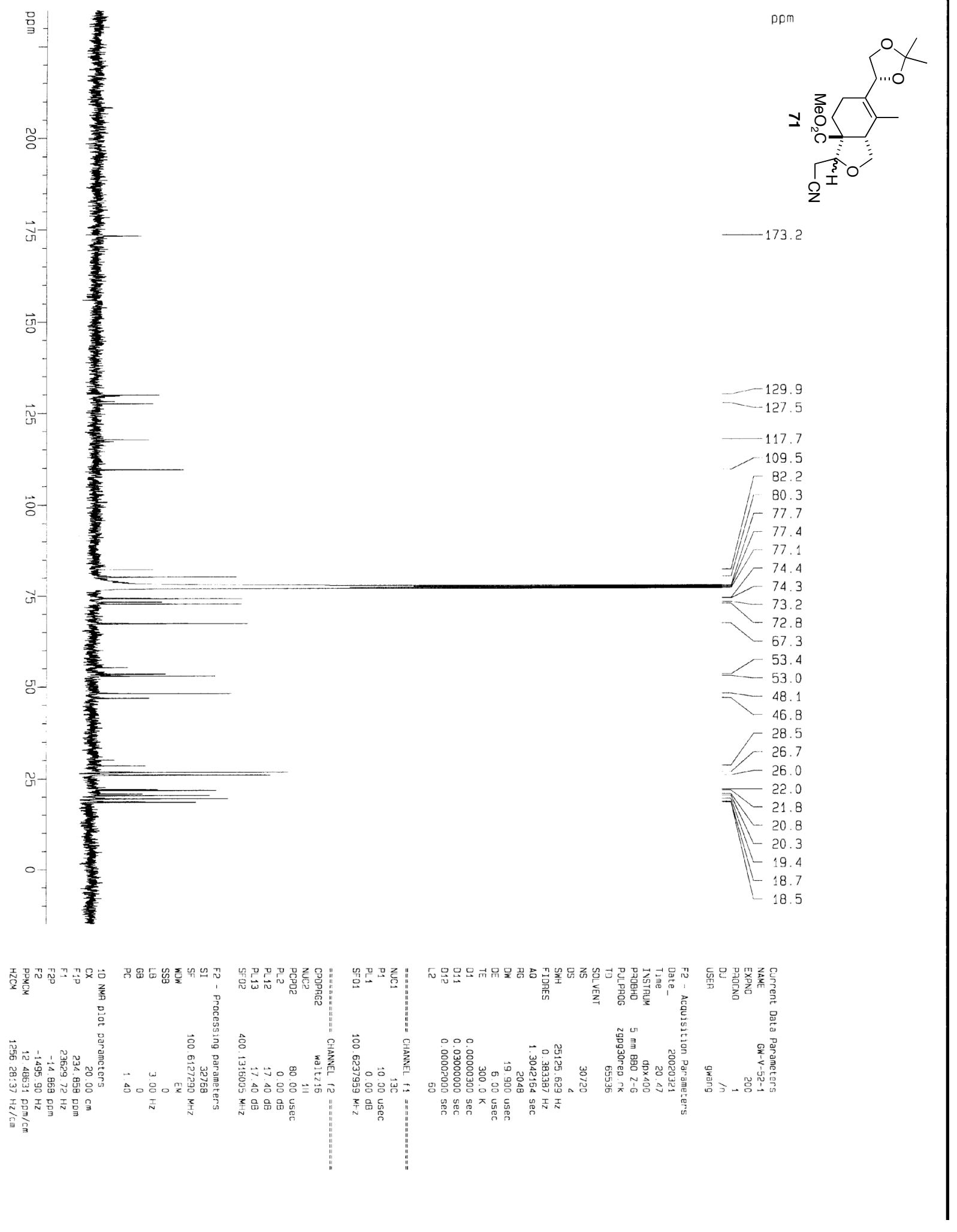




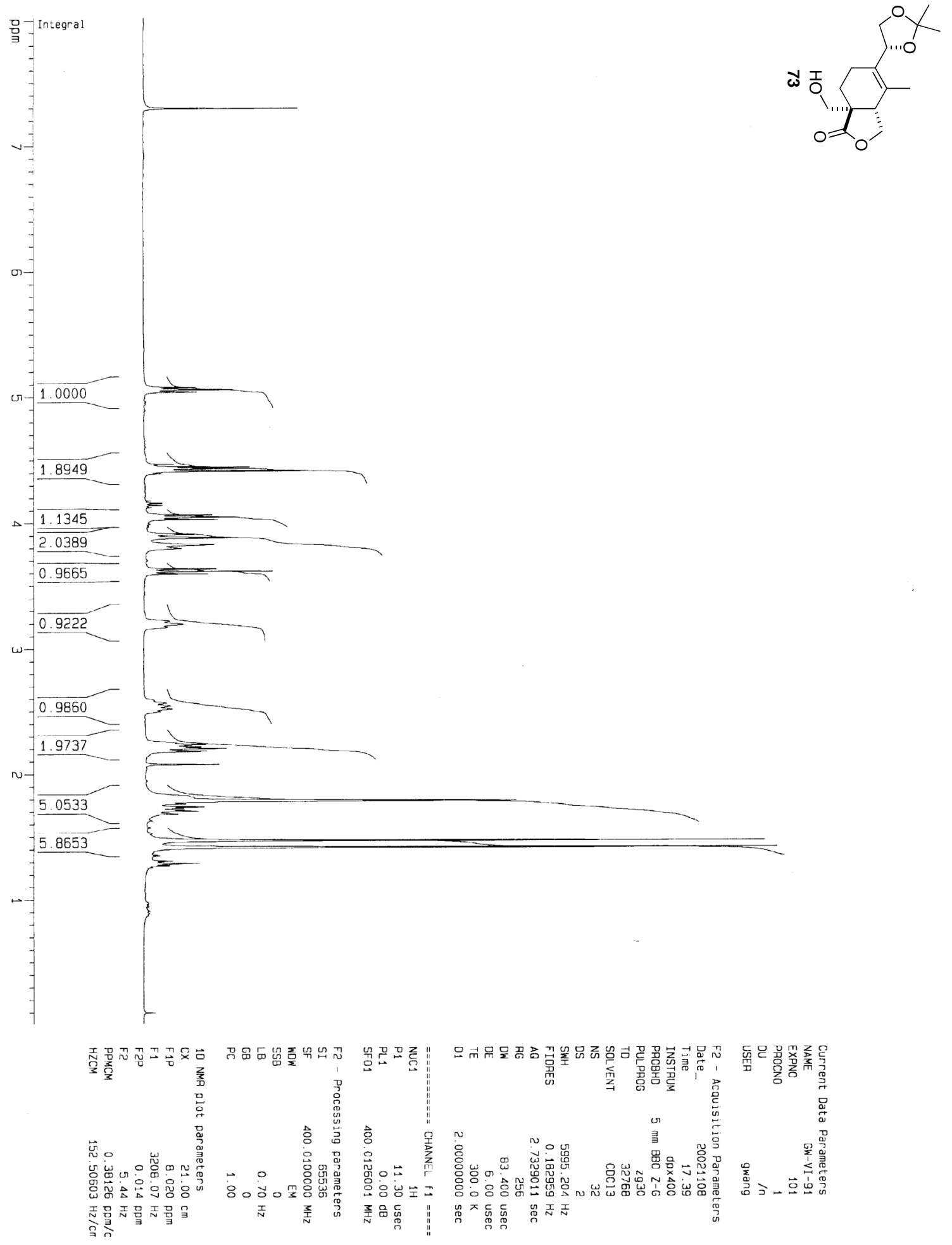



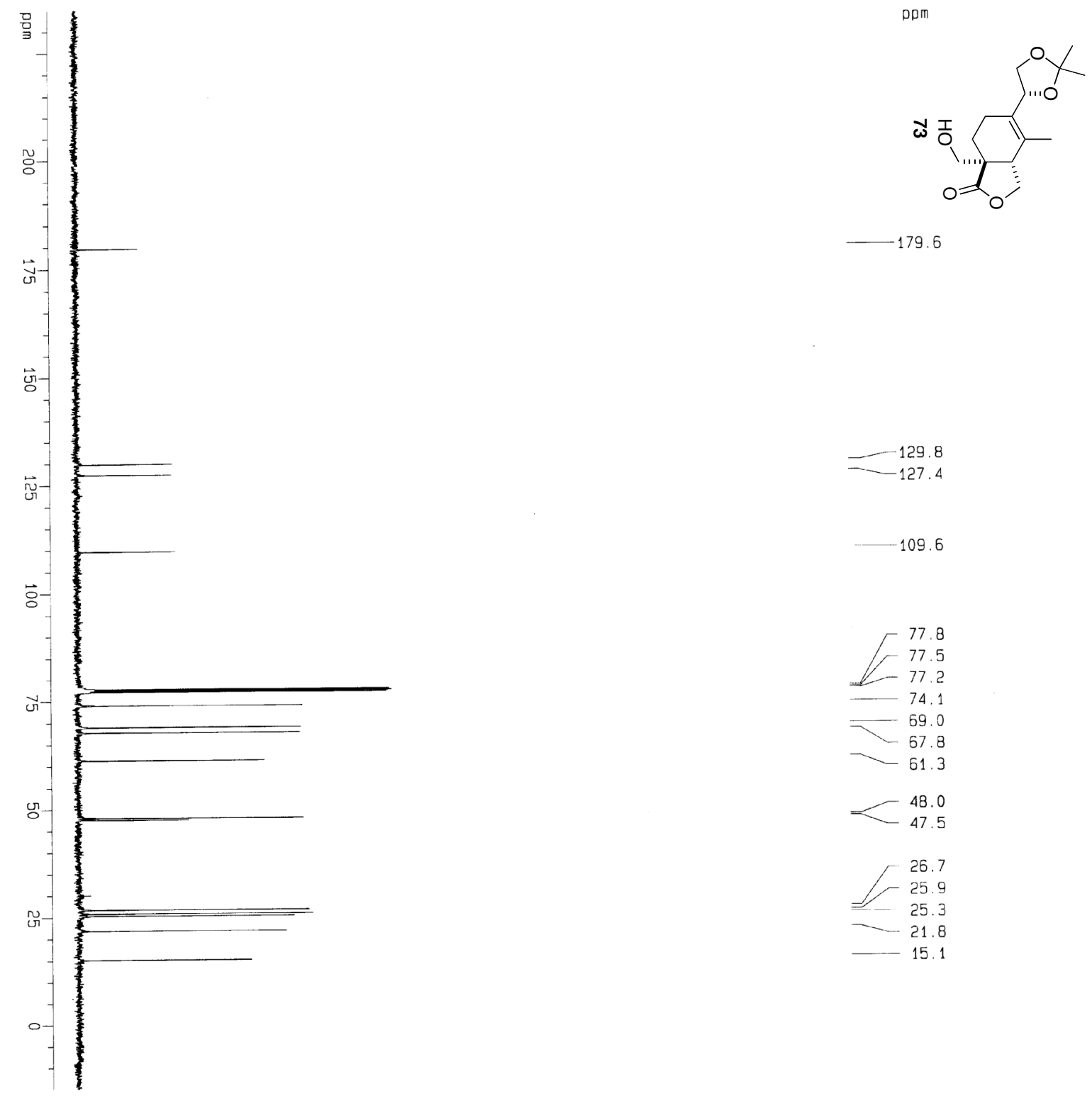

$-109.6$
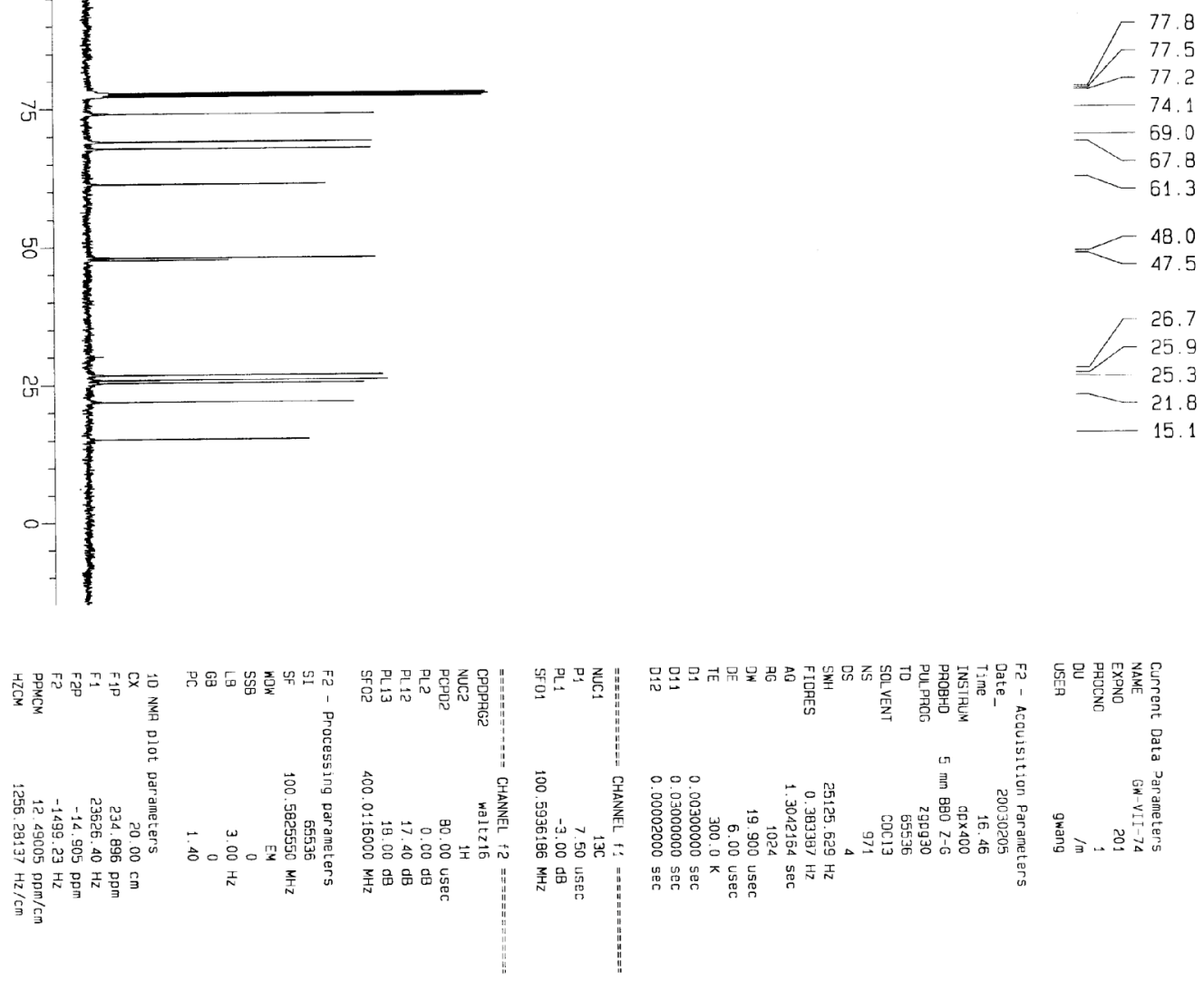


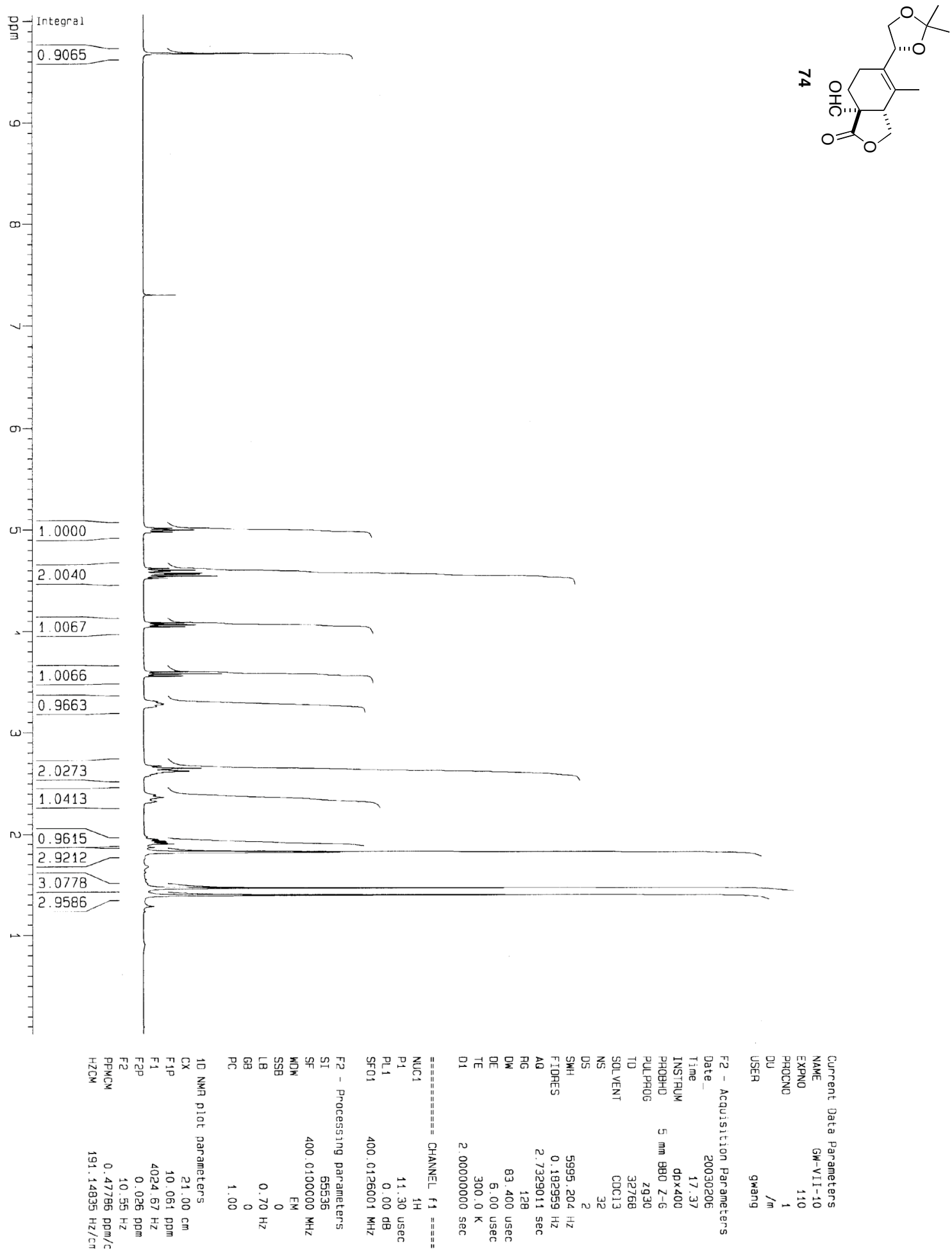




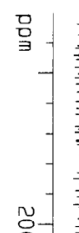

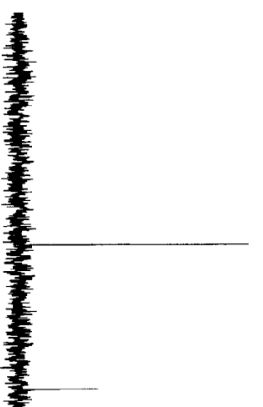




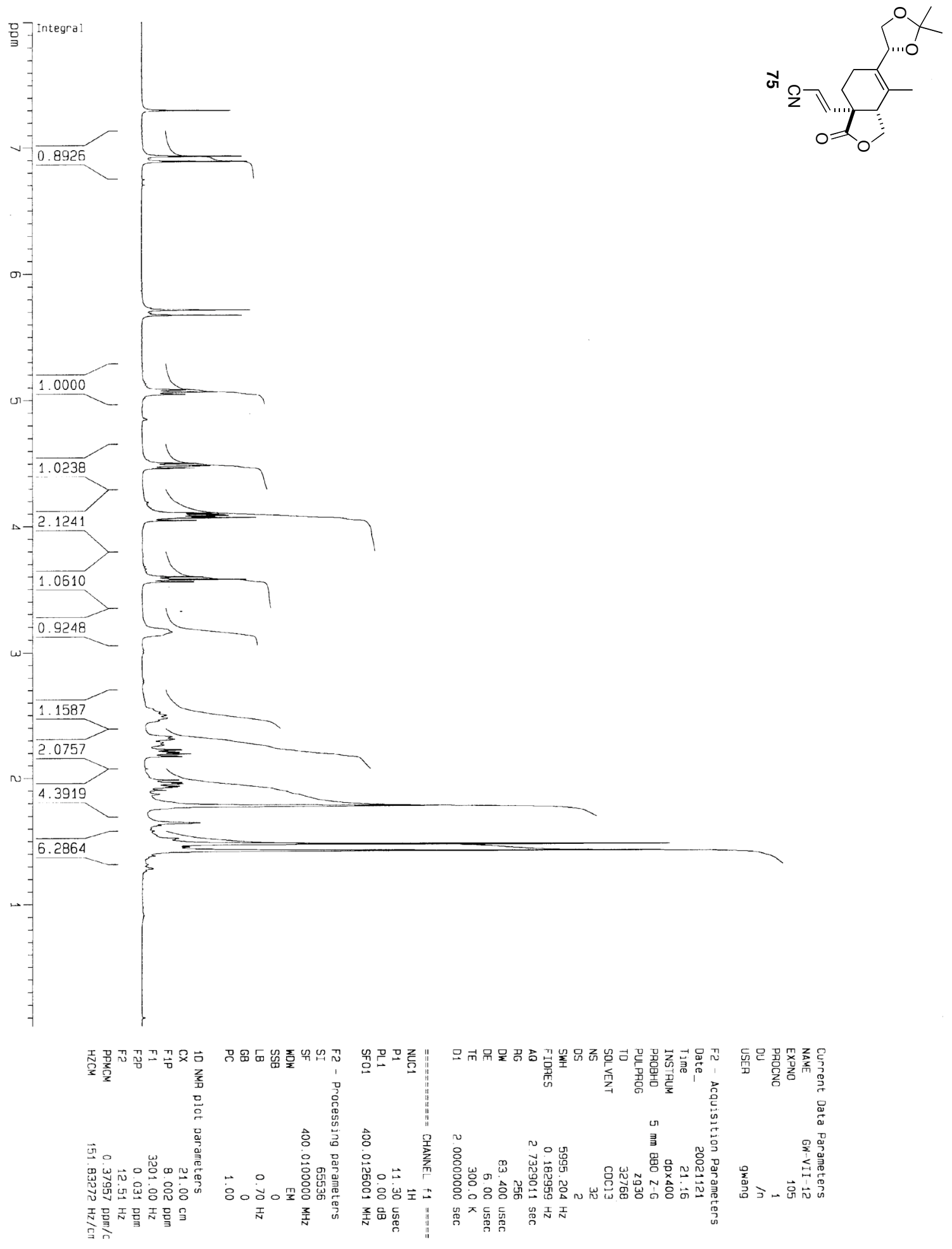



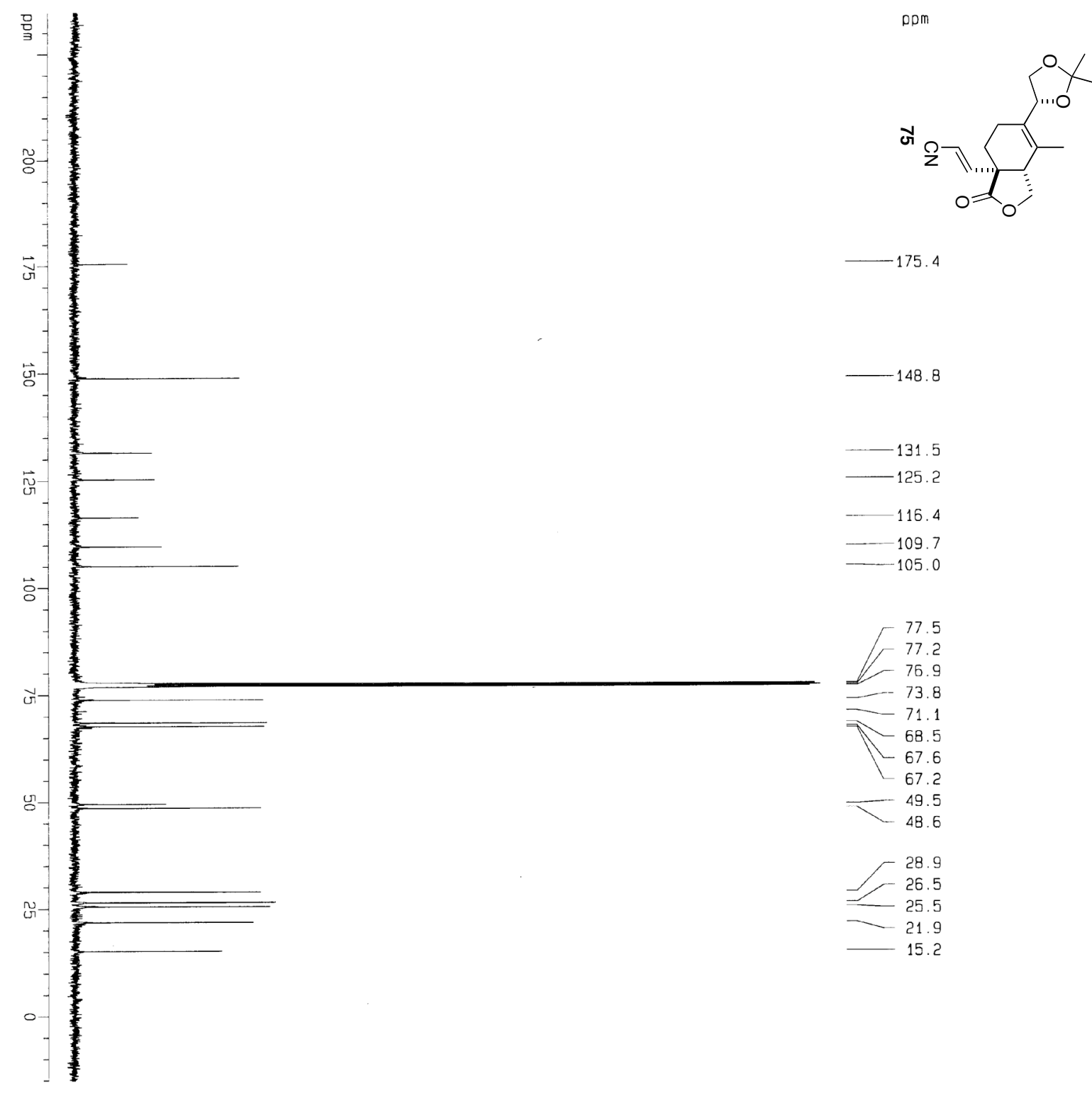

$-131.5$

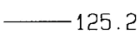

$-116.4$
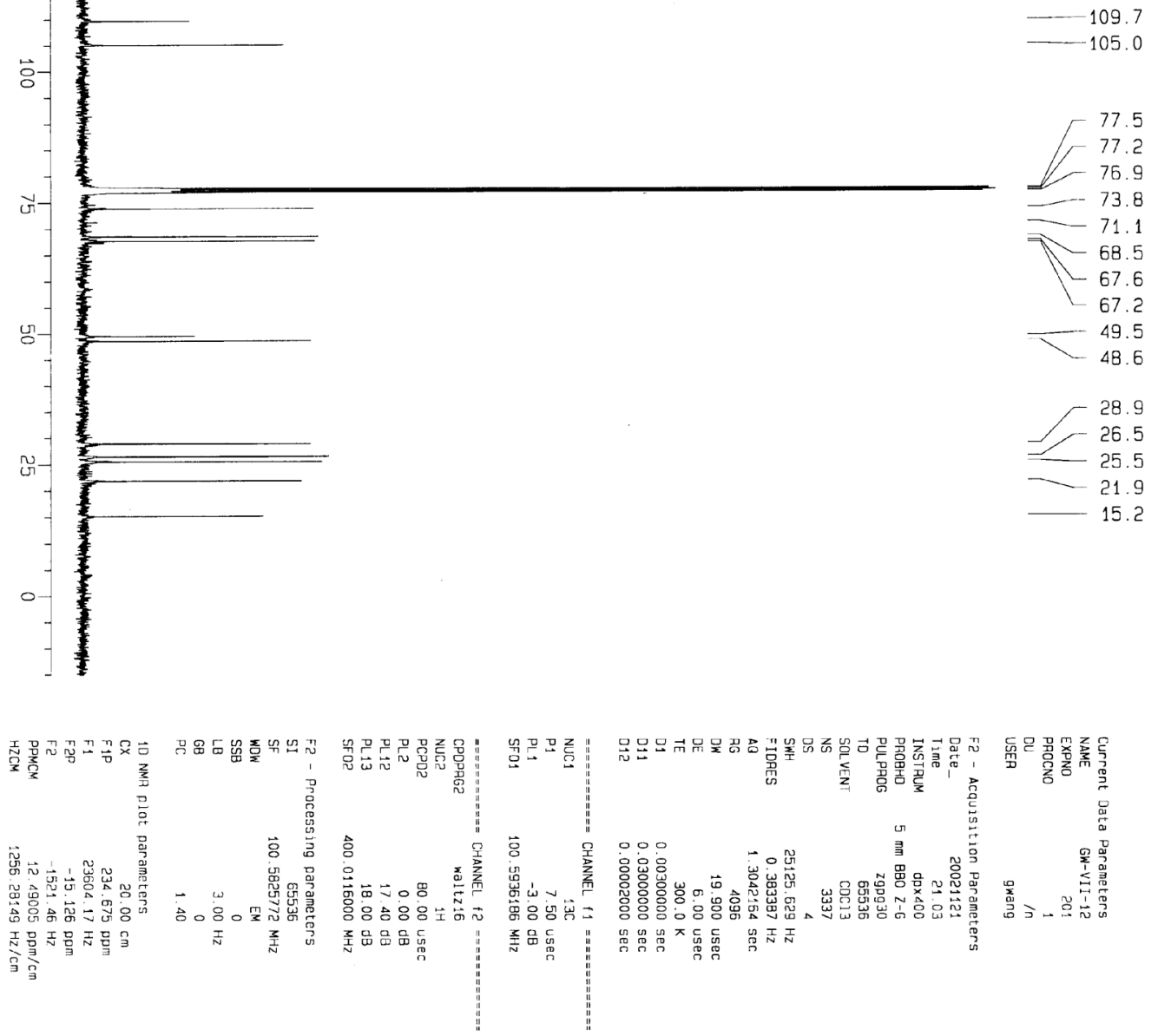


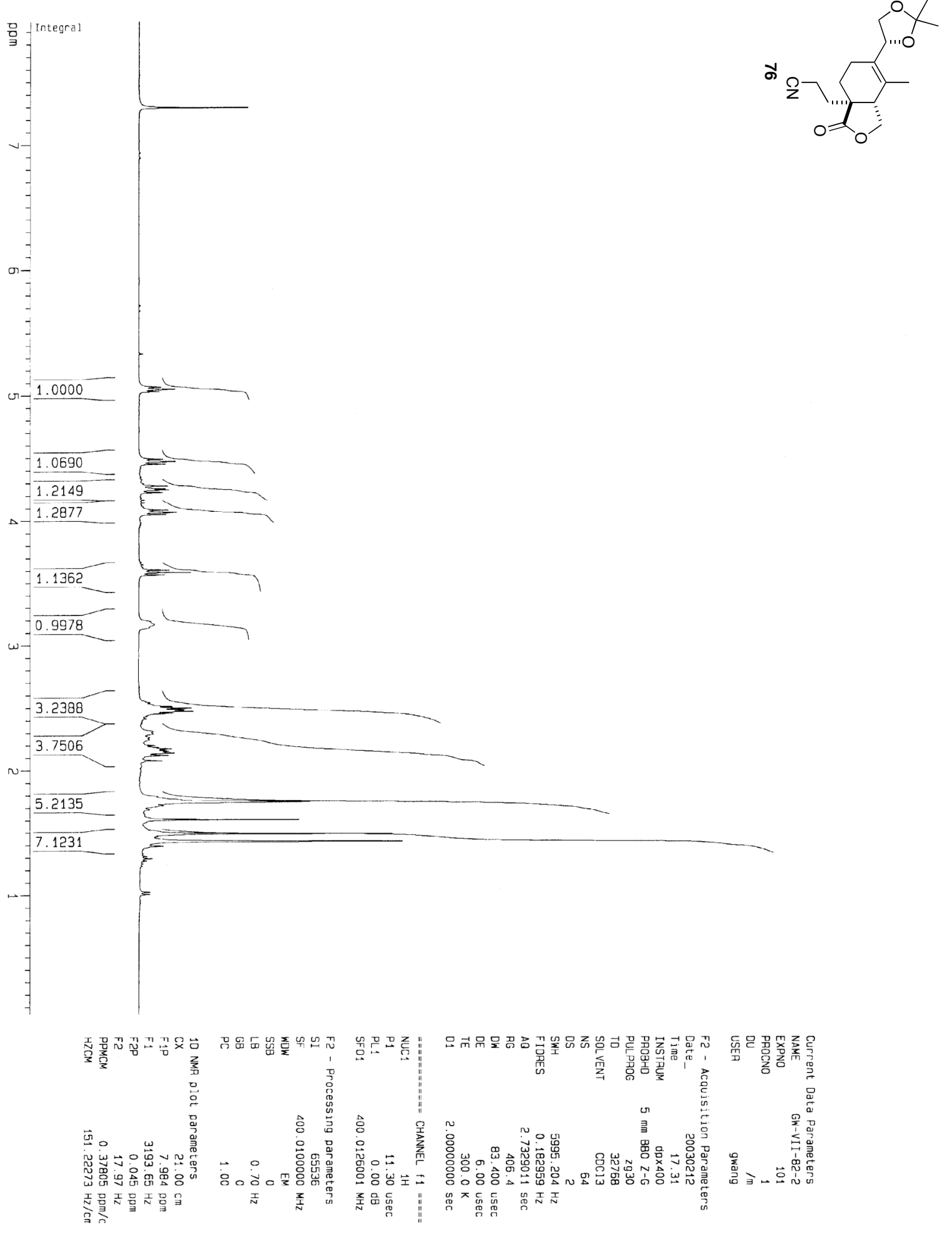




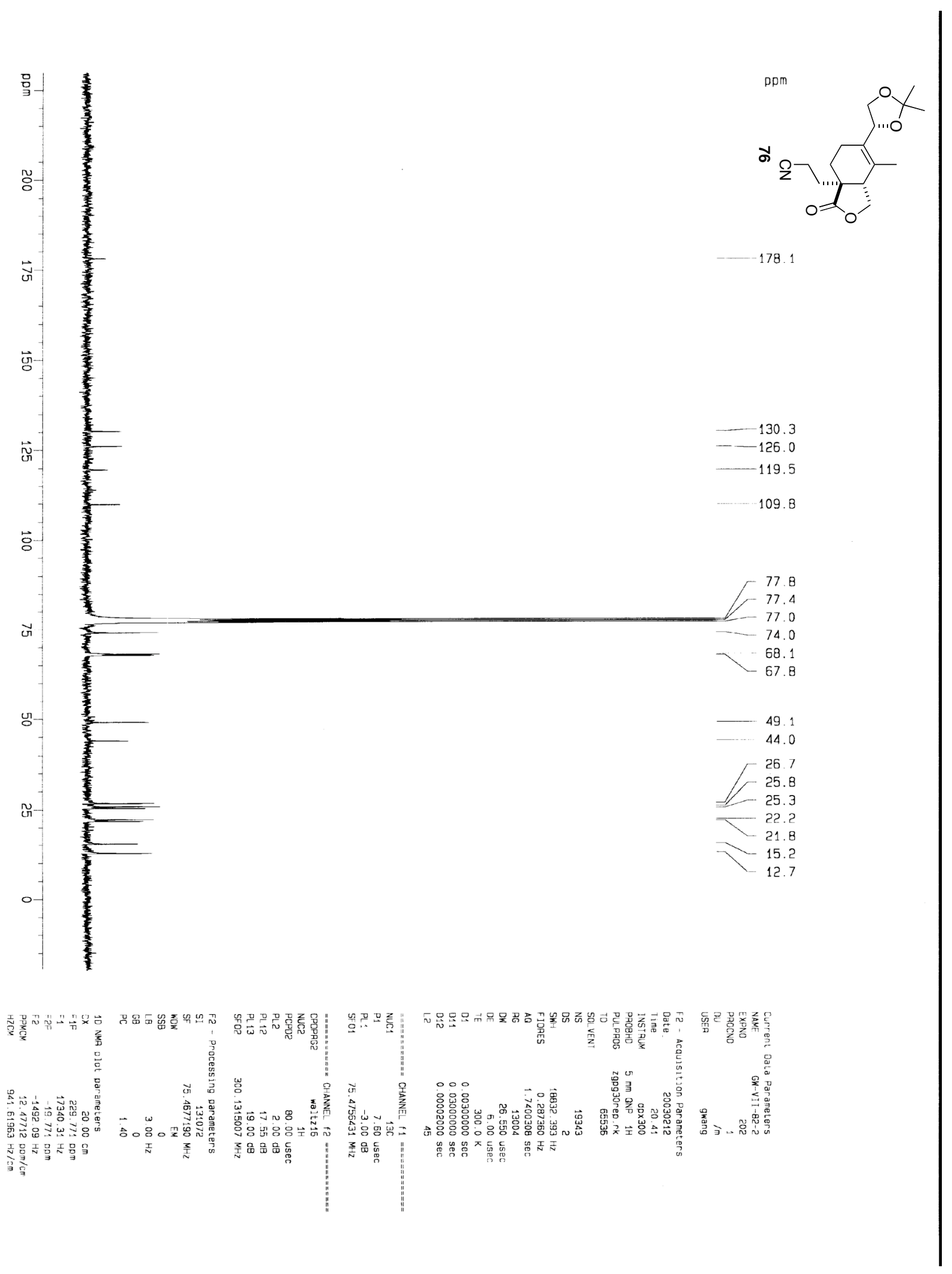




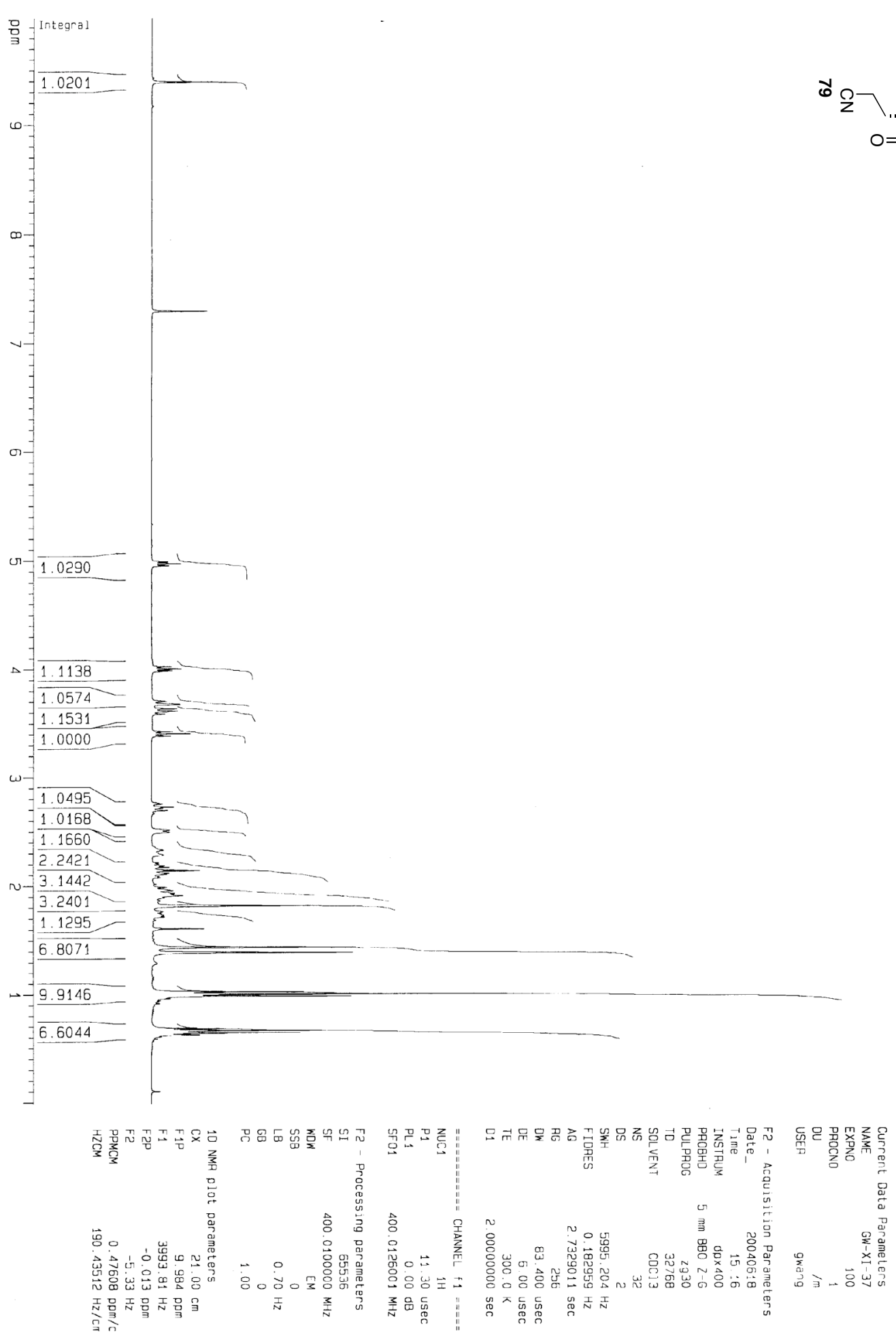




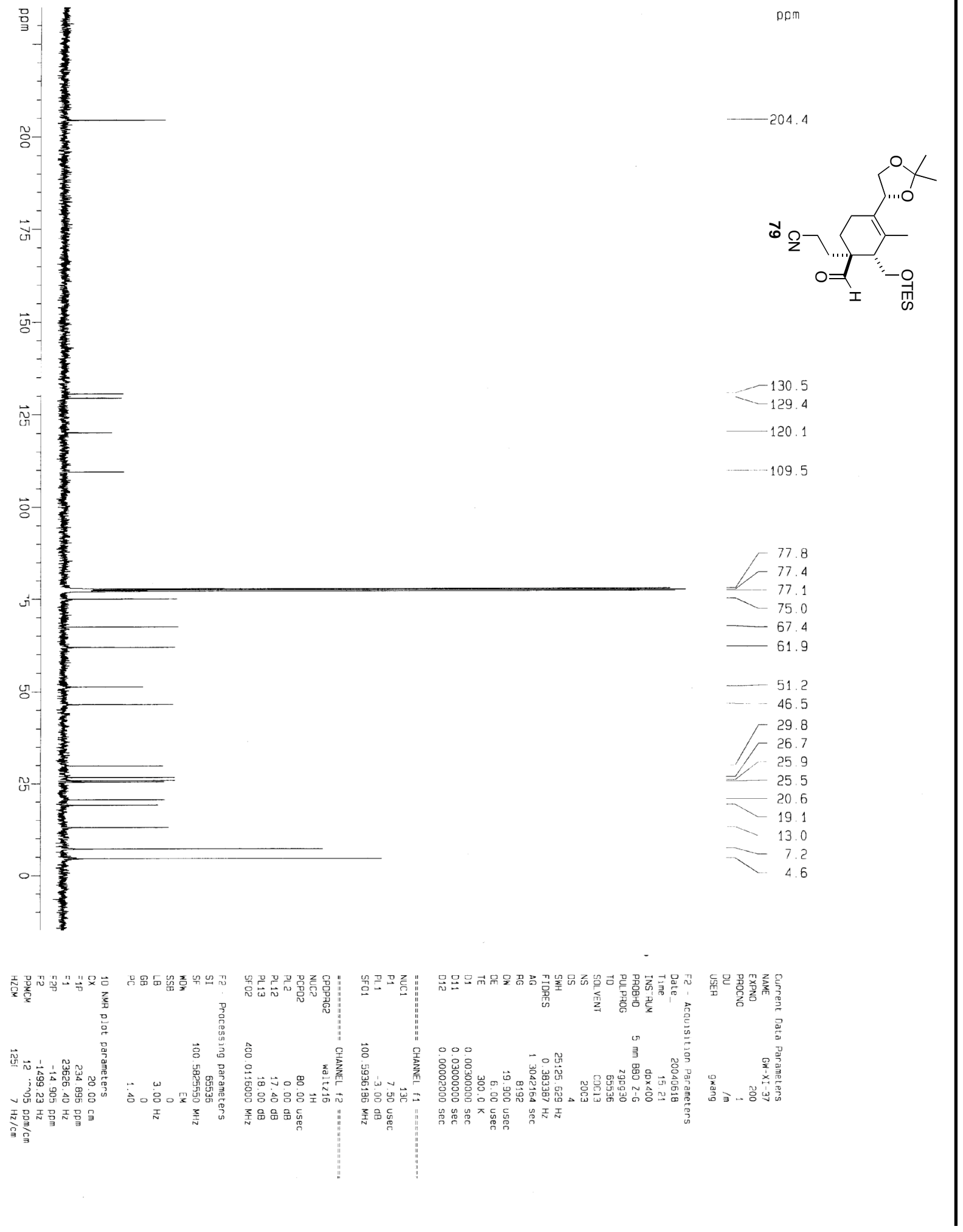




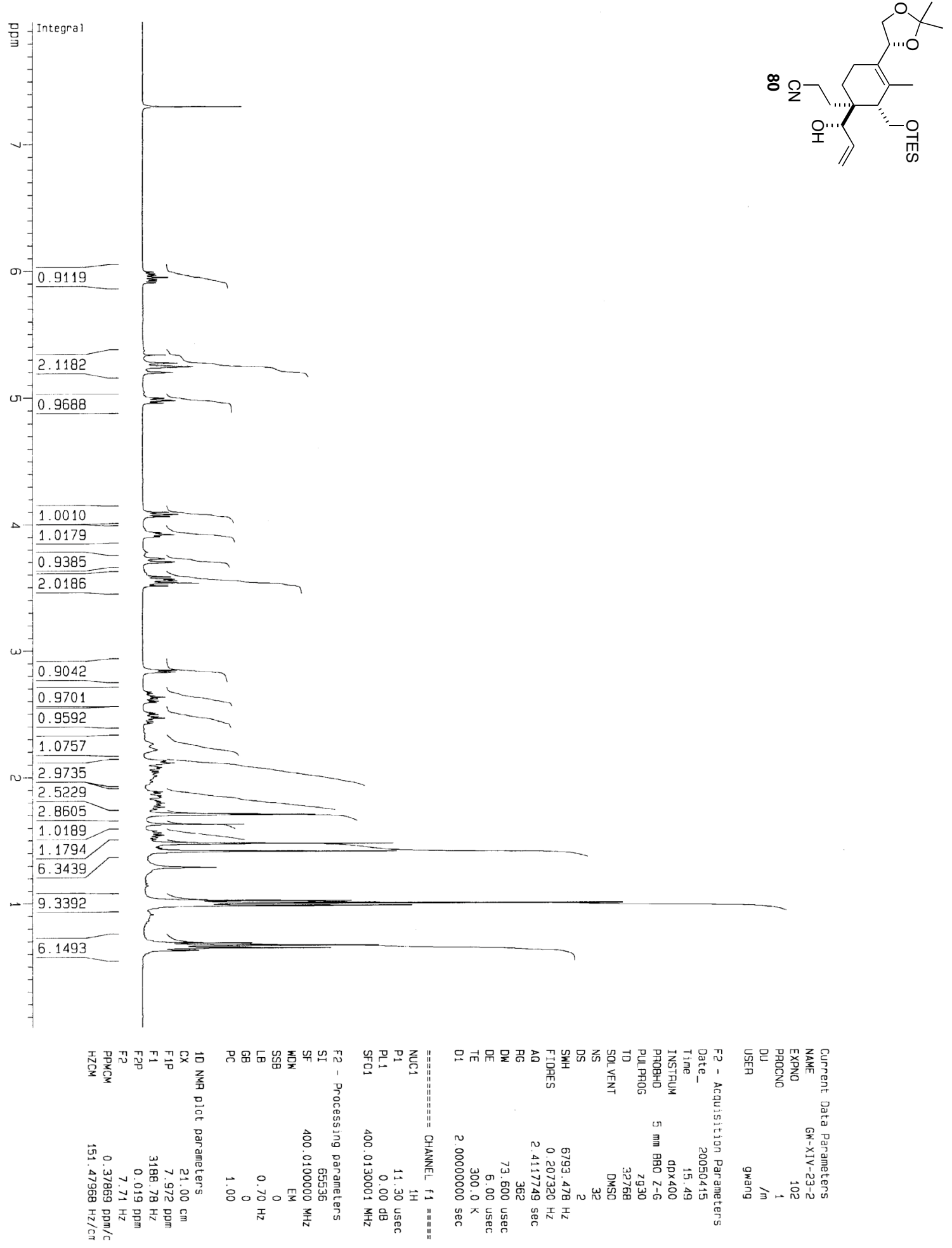



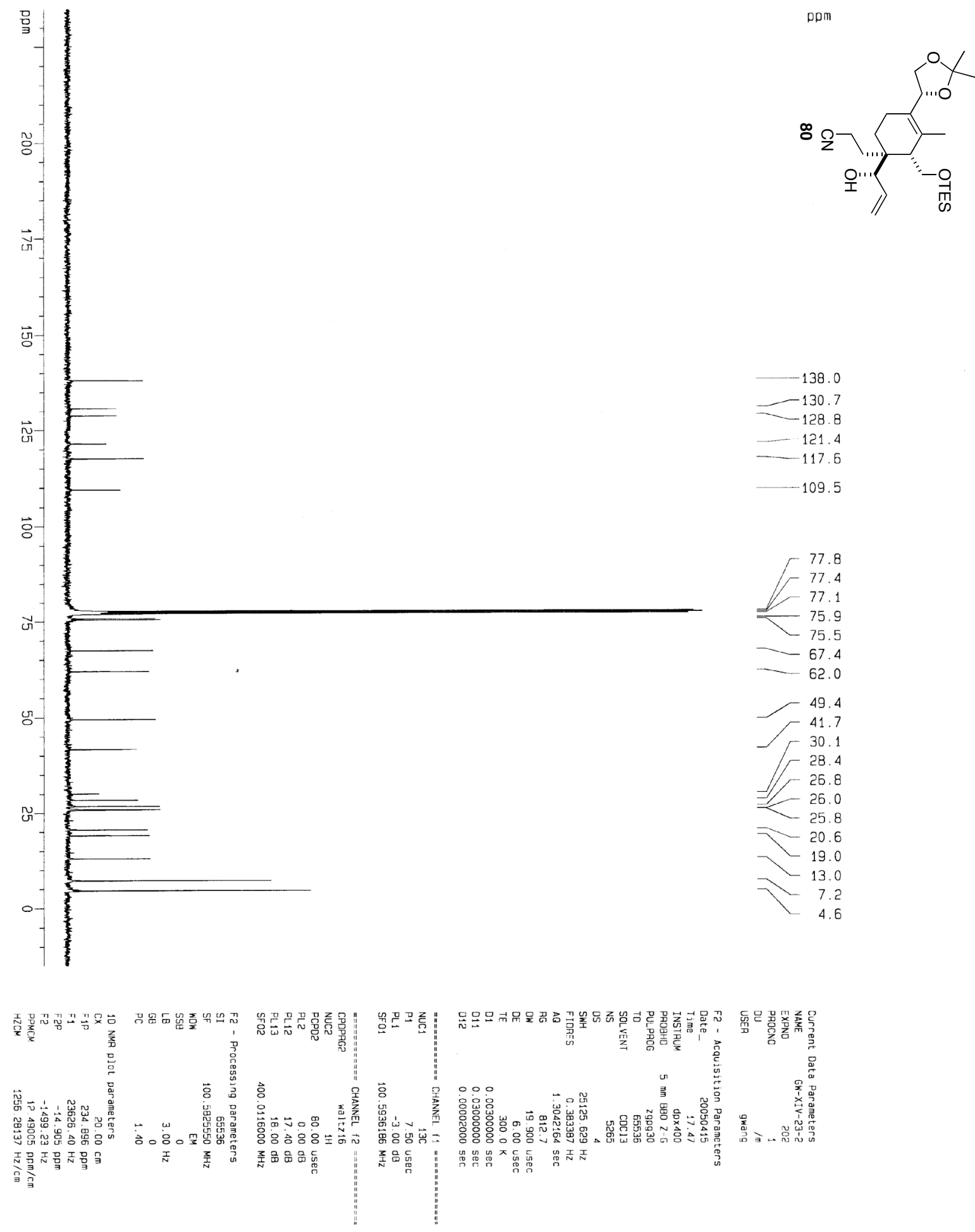

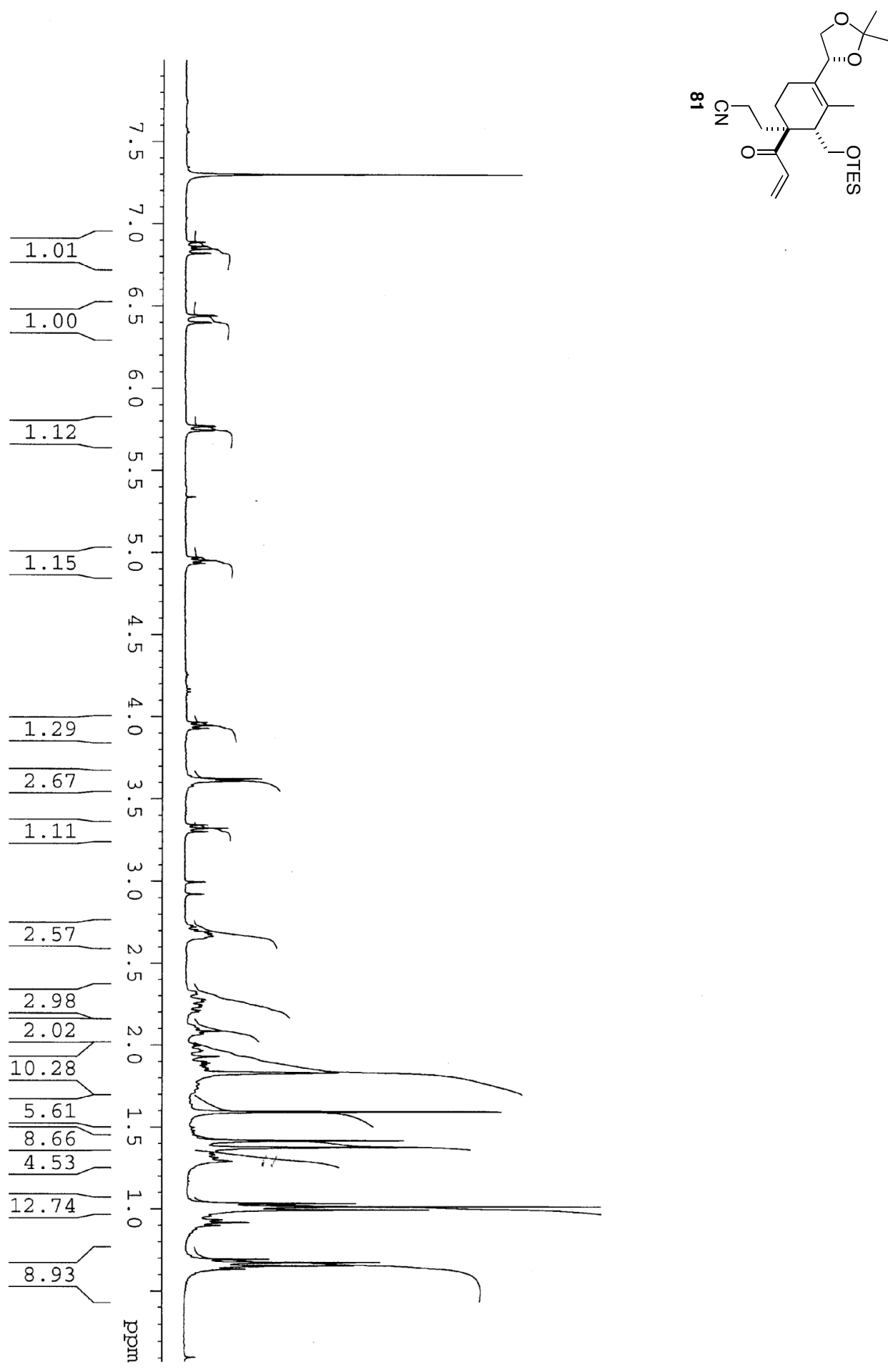


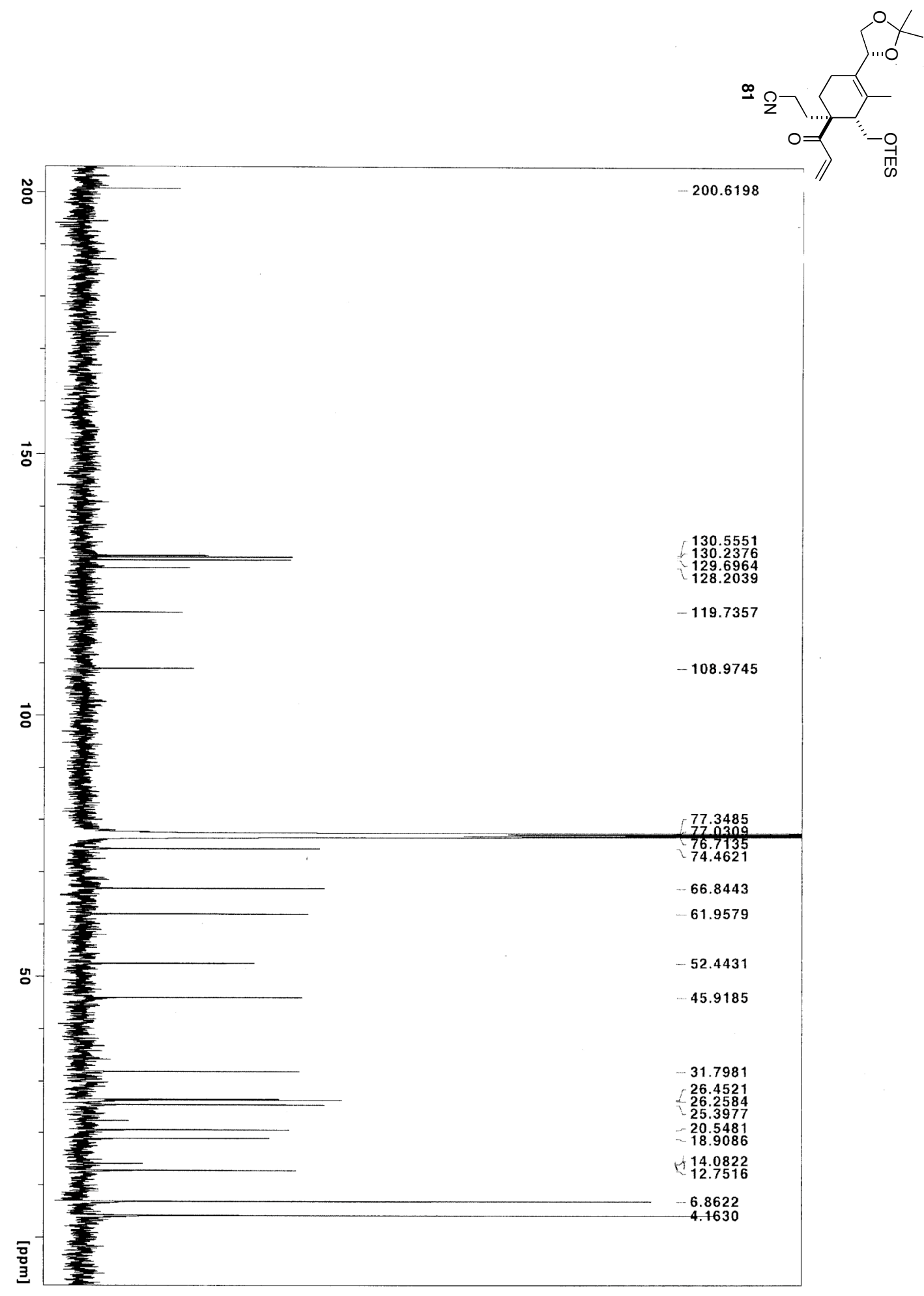




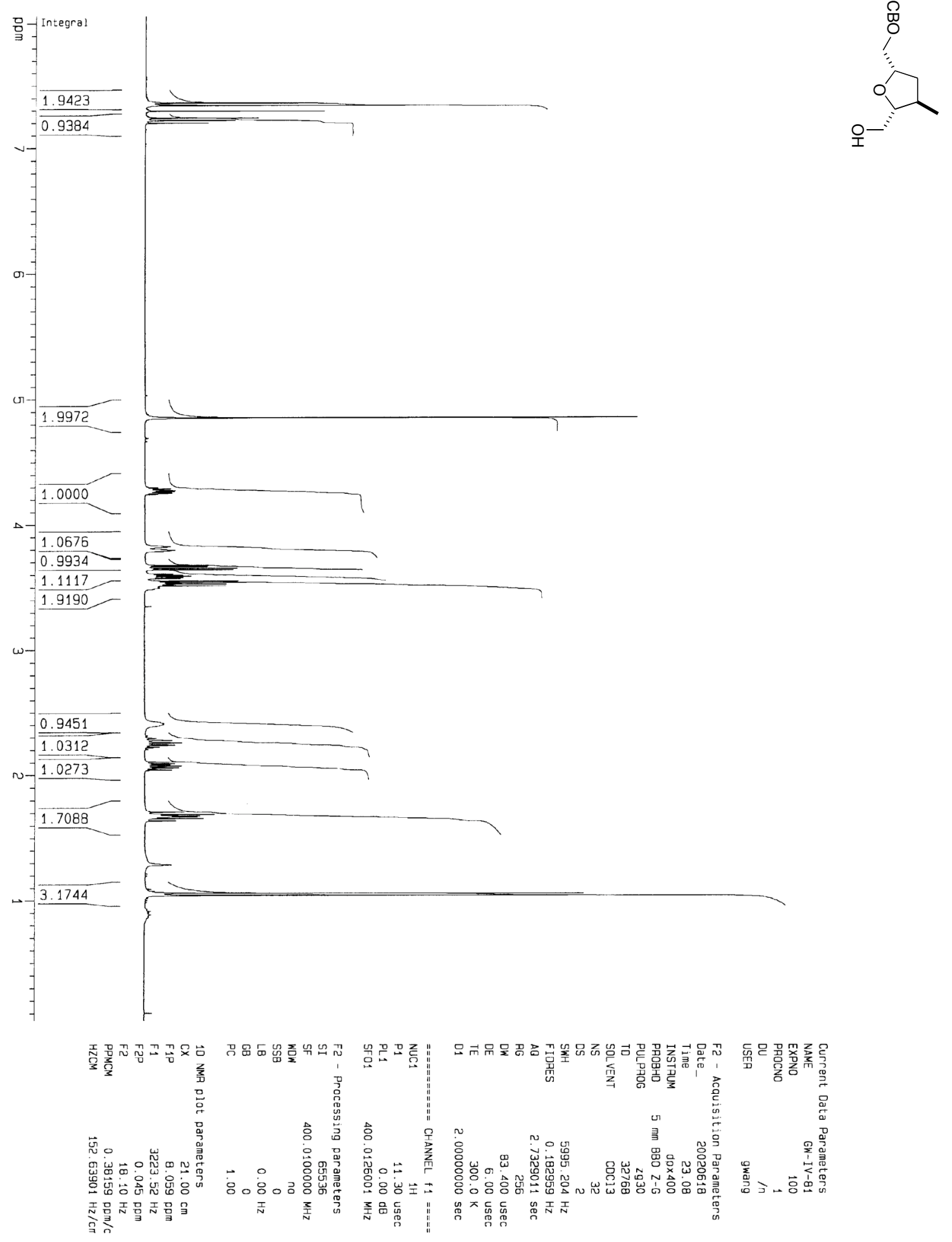




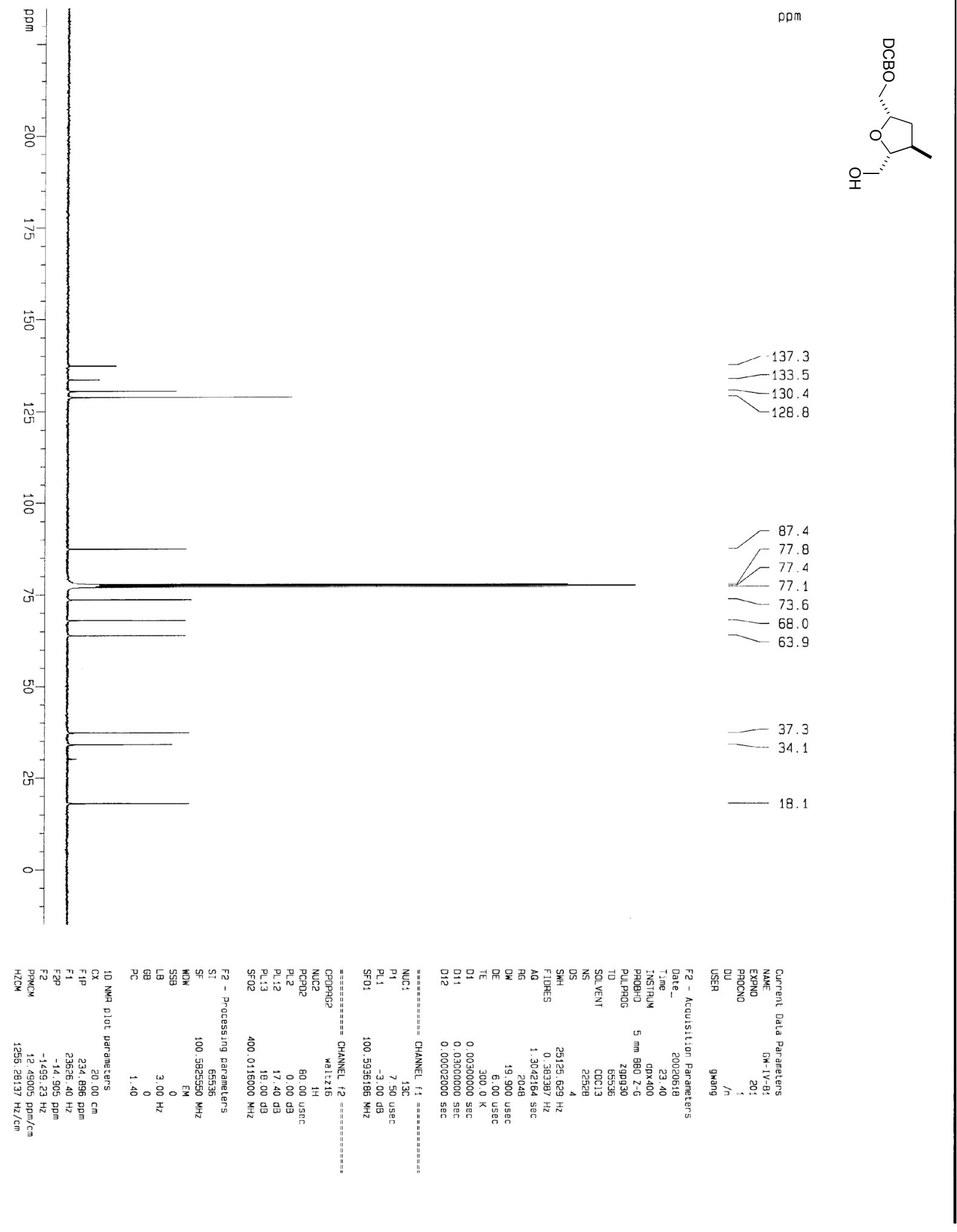



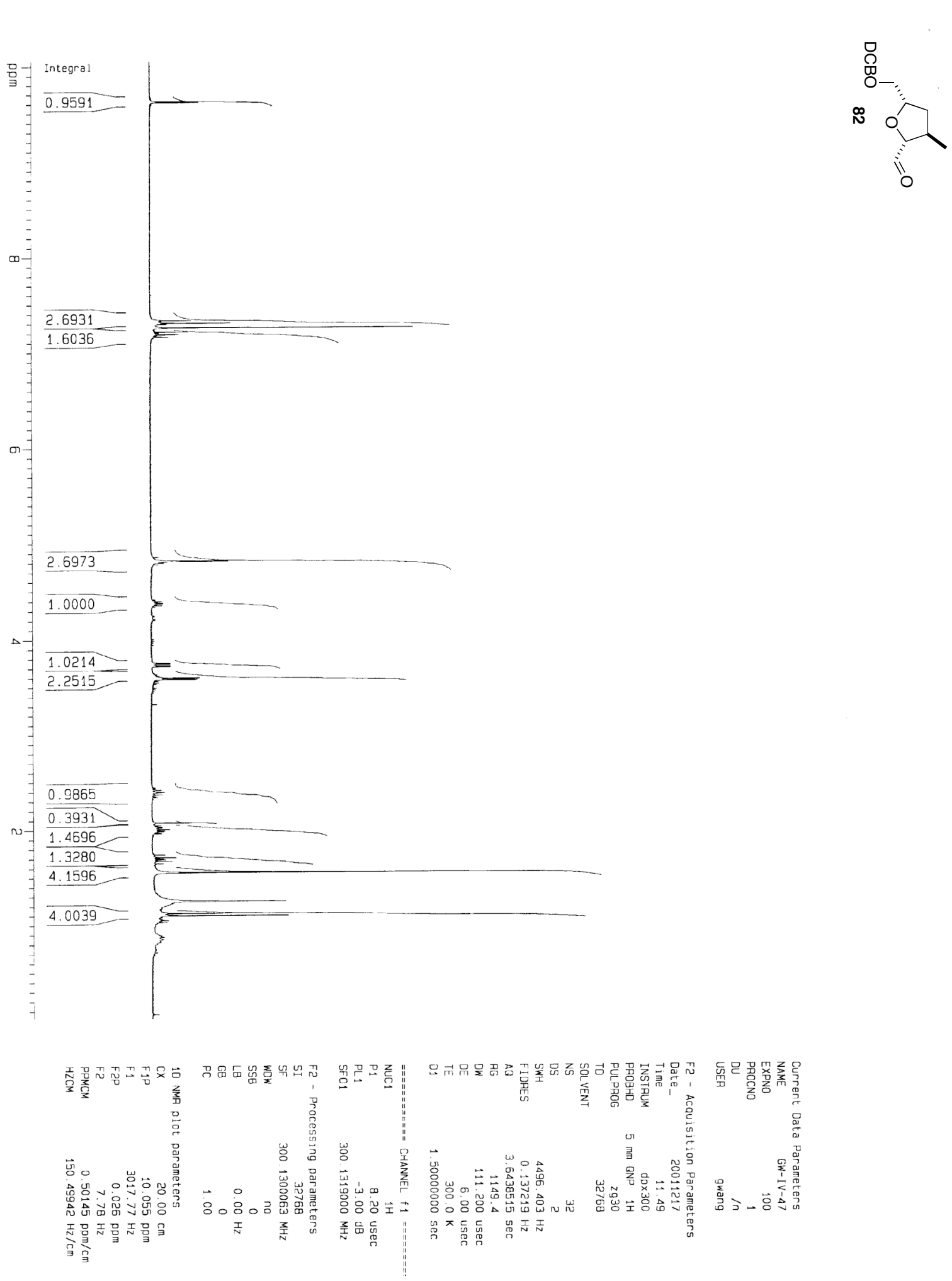

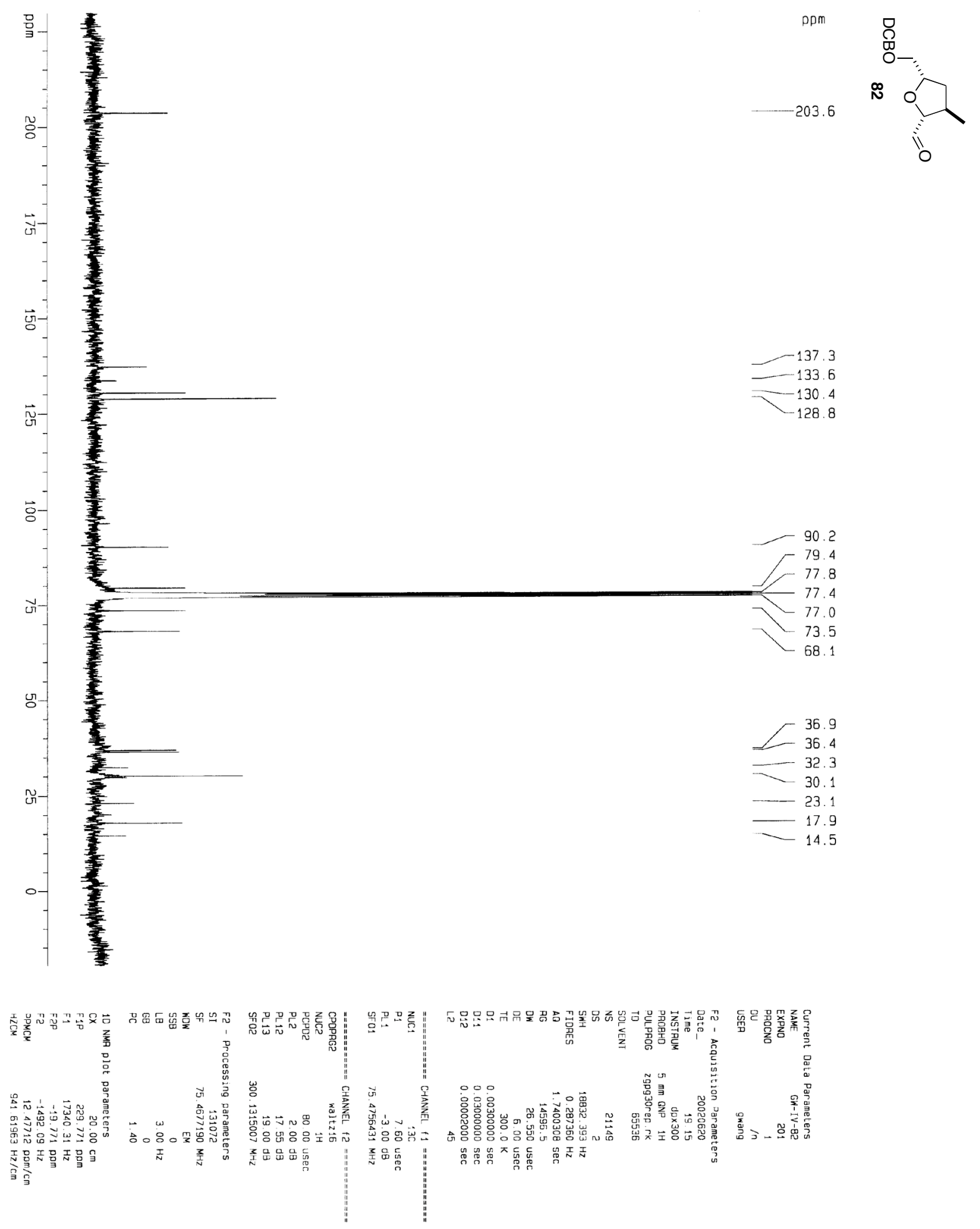


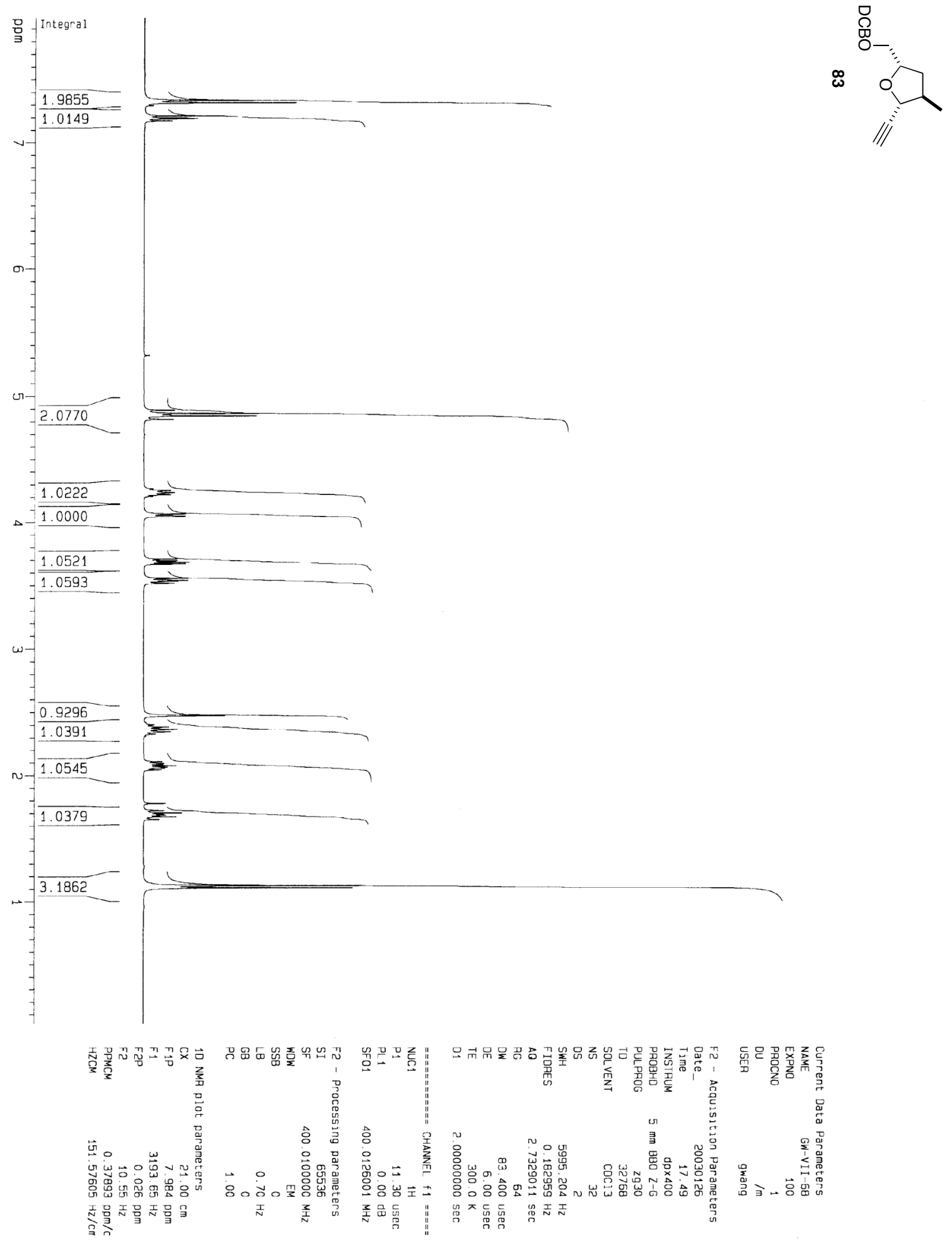



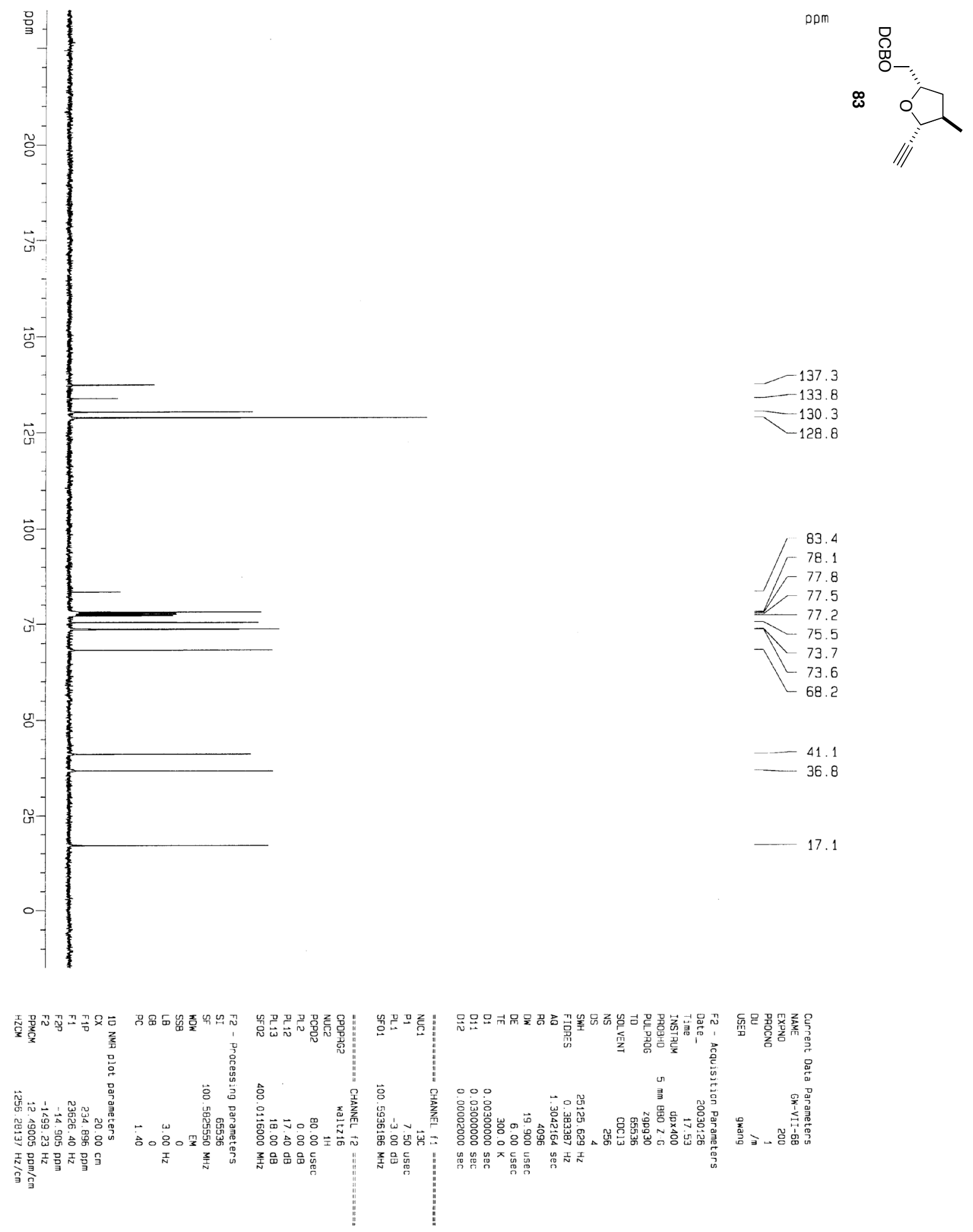


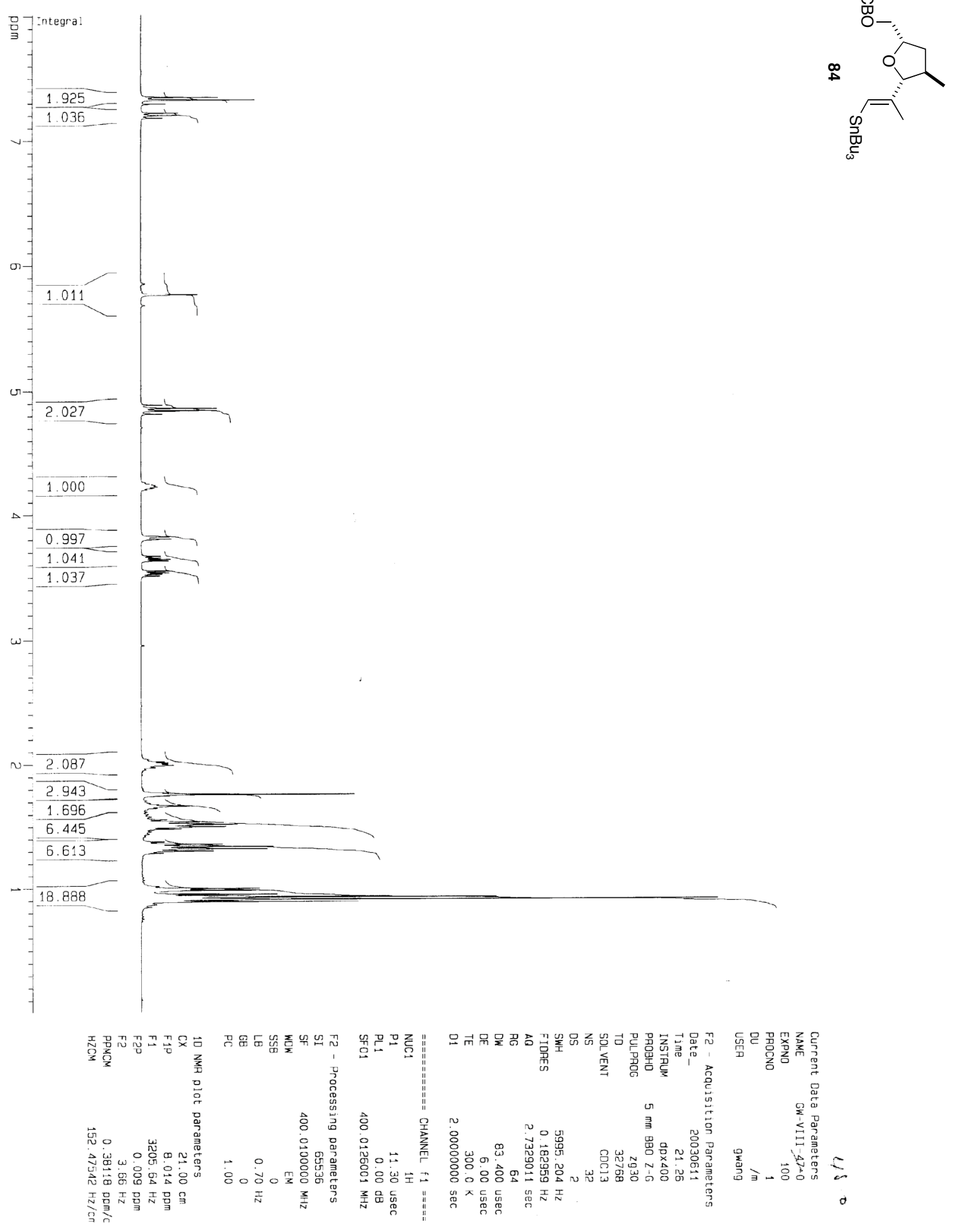




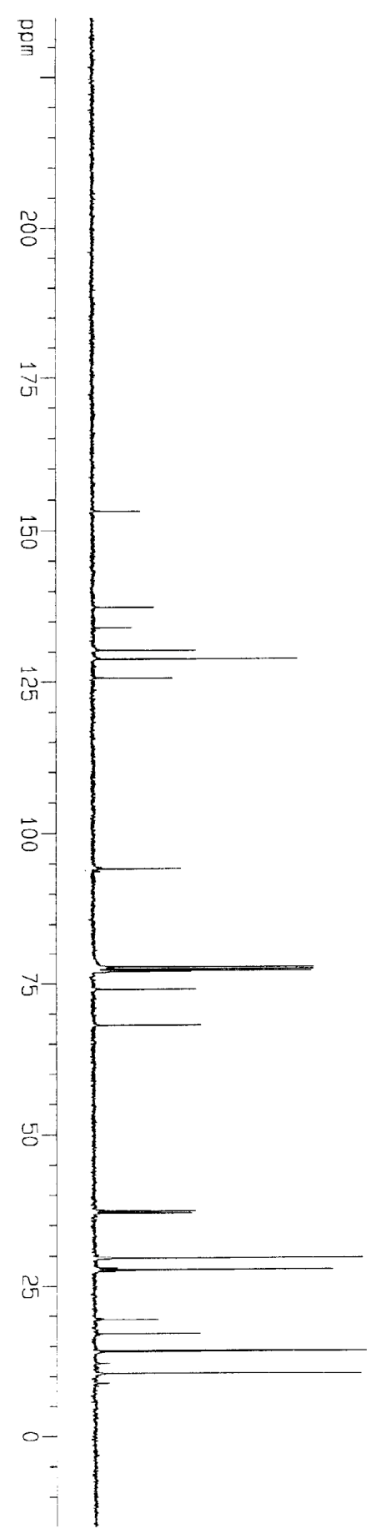

ppm
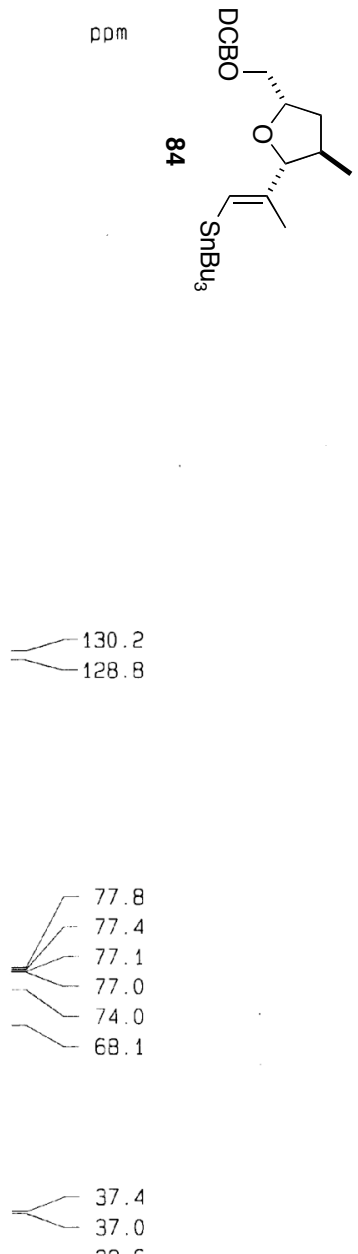

-29.6
$-\quad-7$

17.1

17.1
14.1

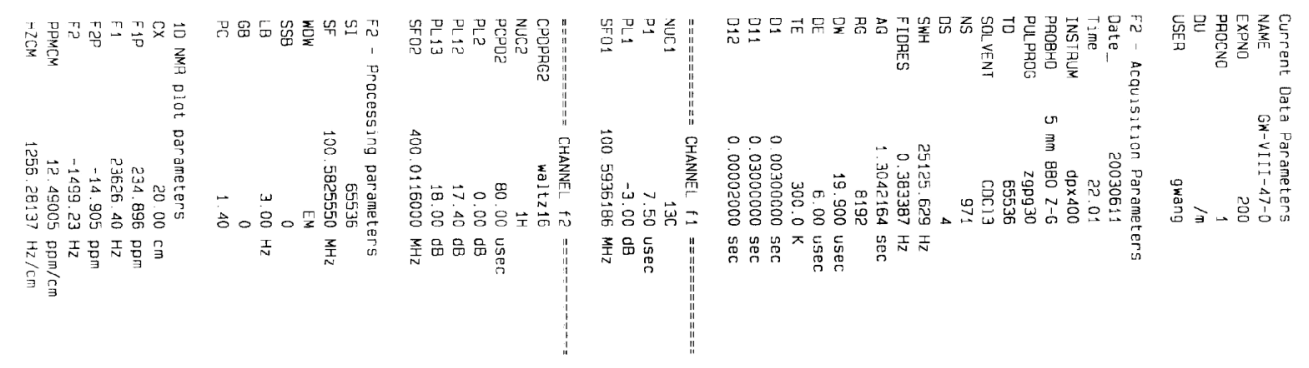




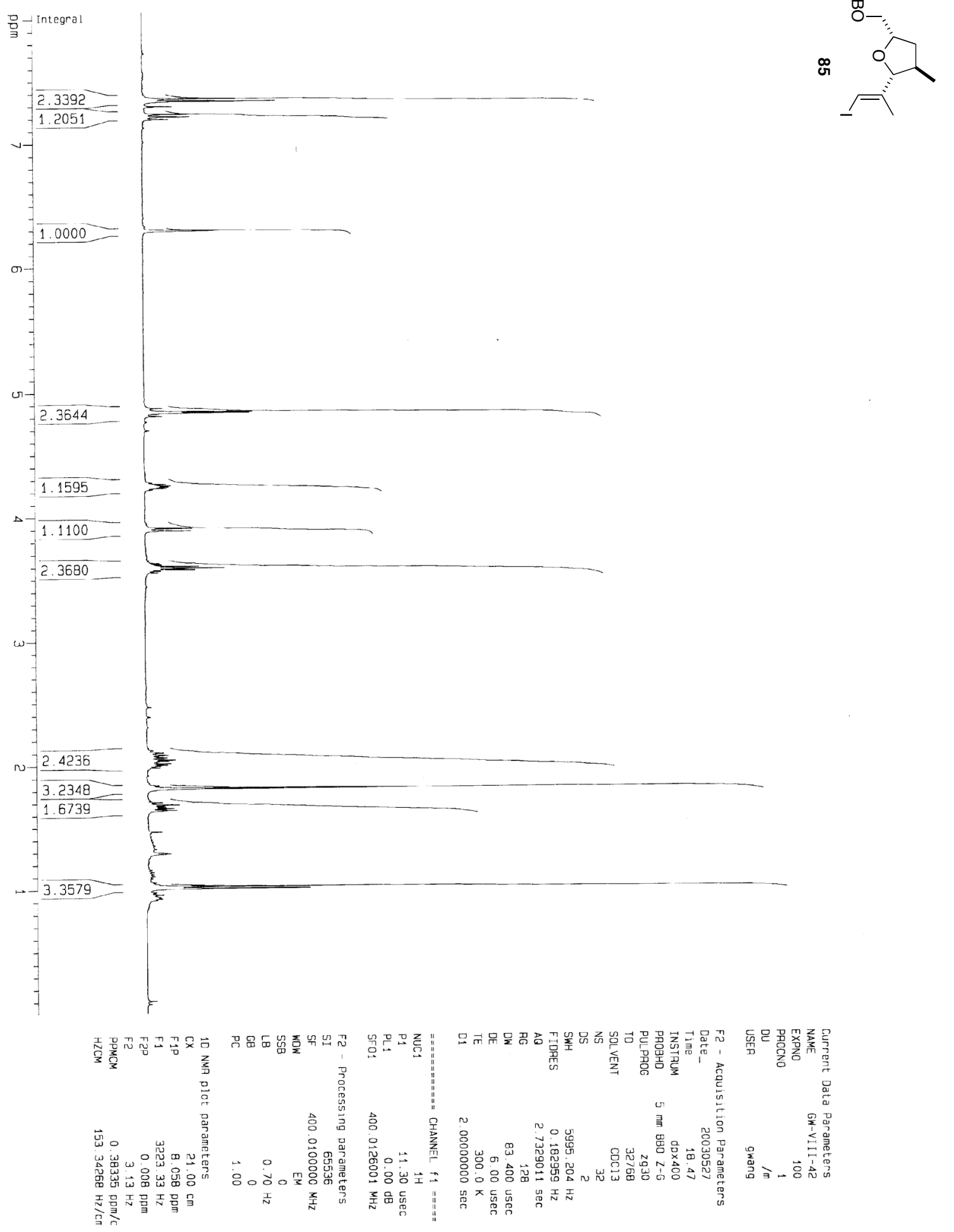




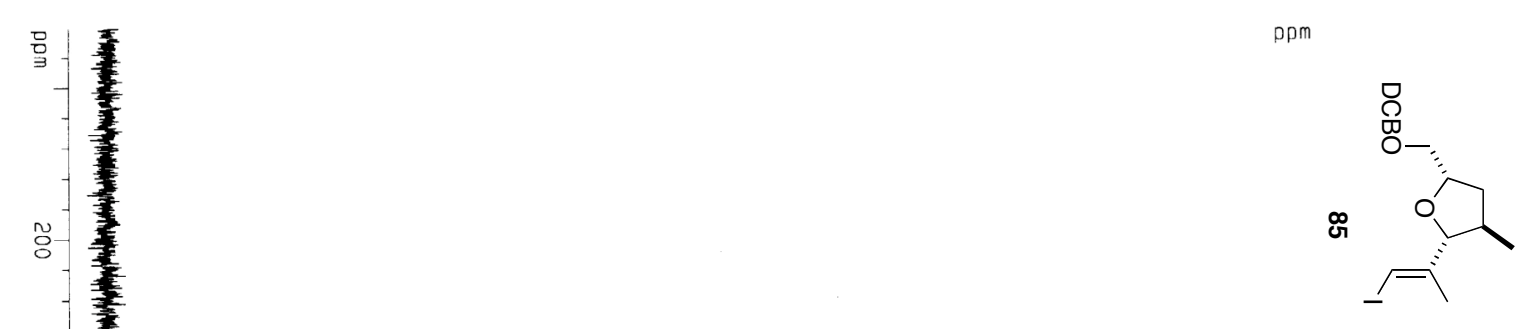

(

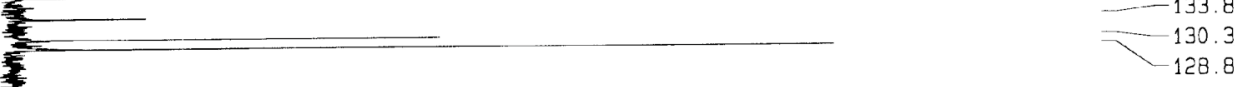

$-\quad-147.6$

$-137.3$

$-133.8$

$-128.8$

$\lceil 91.1$

$\Gamma^{79.1}$

77.8

-77.5
-77.3

$-77.1$

$-73 . \%$

68.0

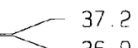

-20.1
-17.4

兒

$\frac{2}{4}$

7. 4

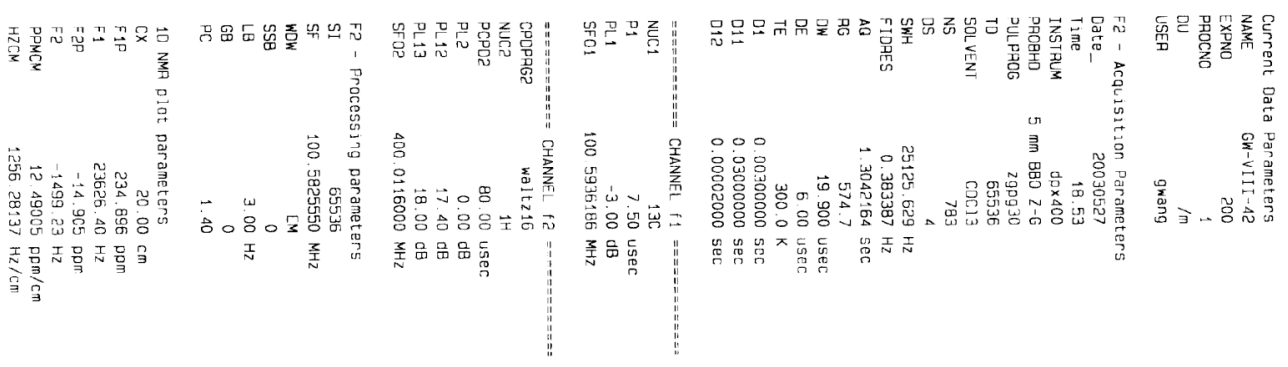




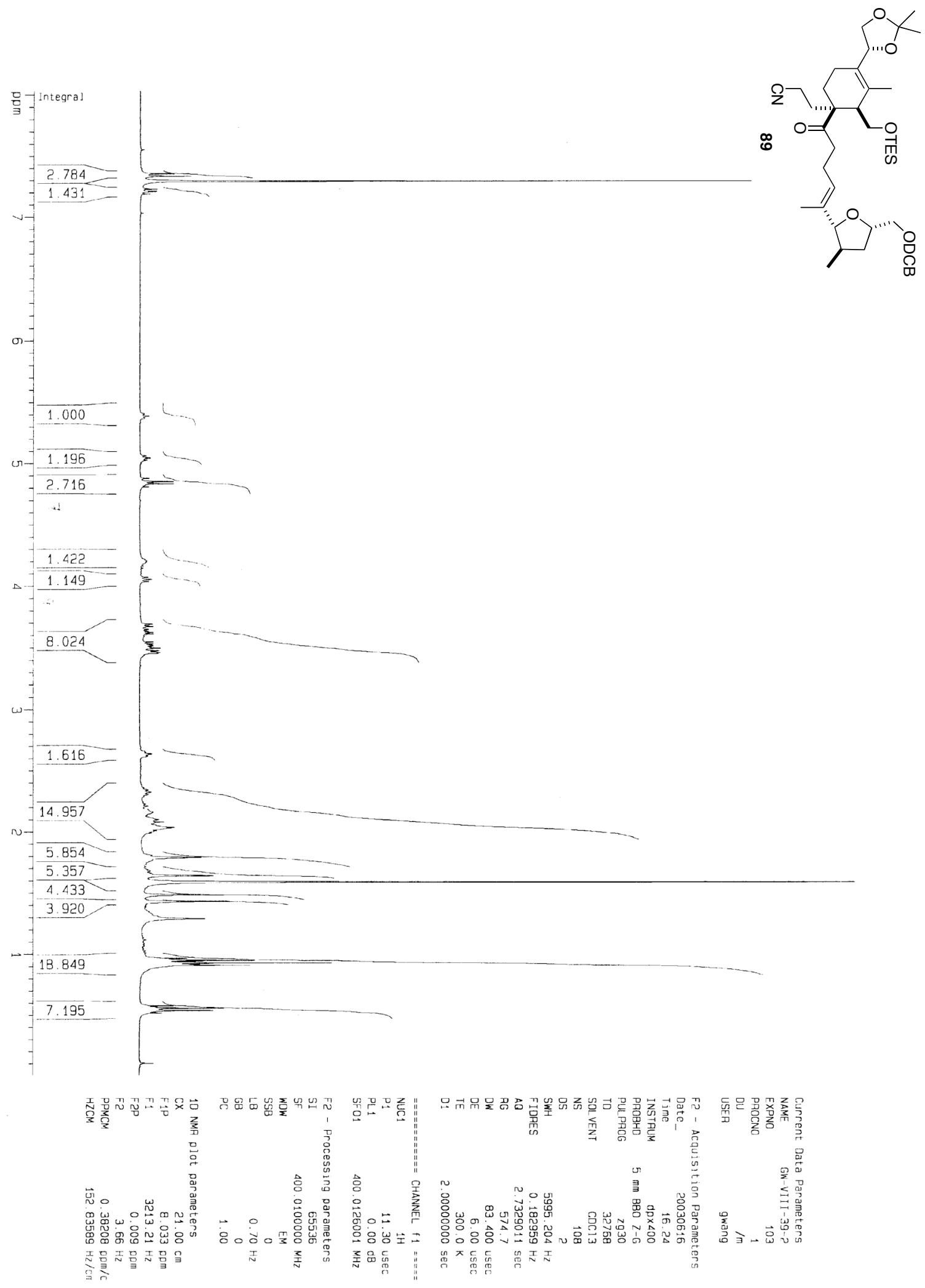



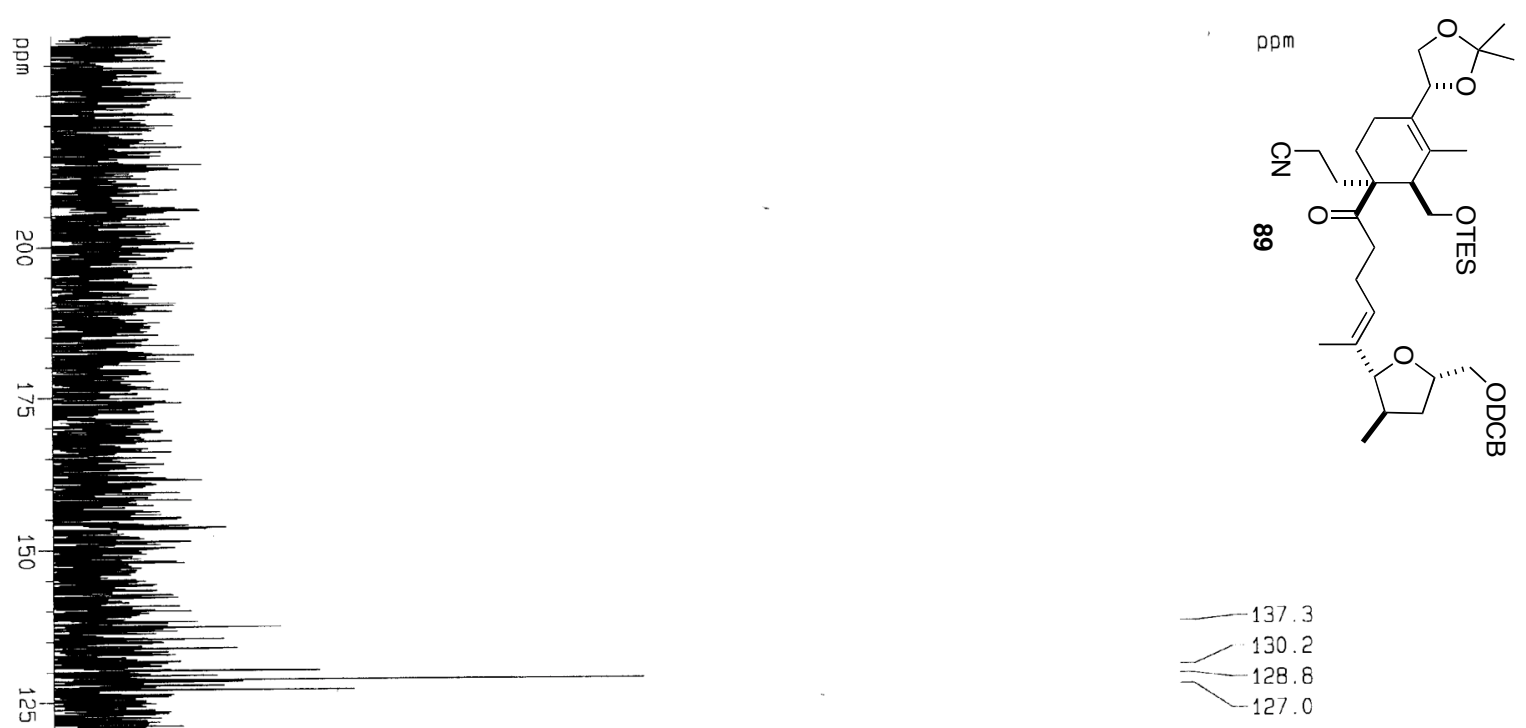

$-137.3$

130.2

$-128.8$

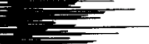

帘

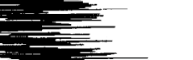

$=74.0$

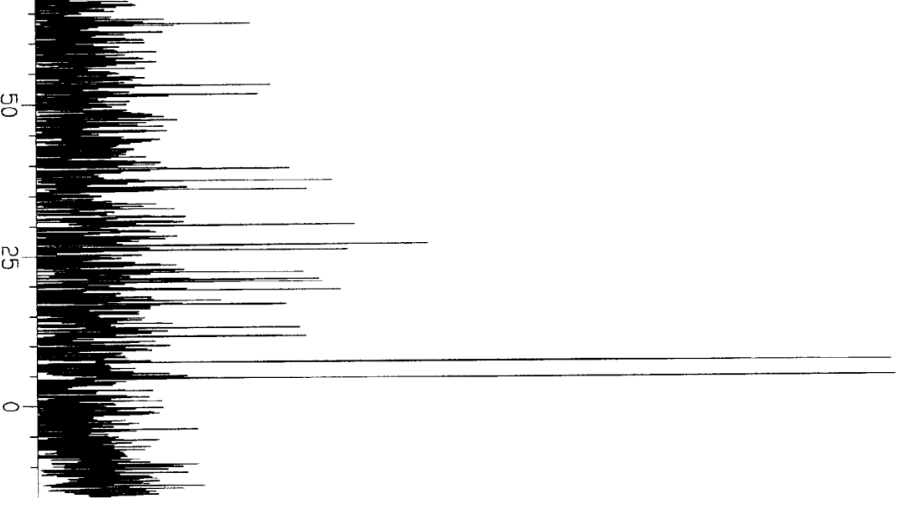

r 92.9

$\int \begin{aligned} & 77.7 \\ & 77.4\end{aligned}$

$-77.1$

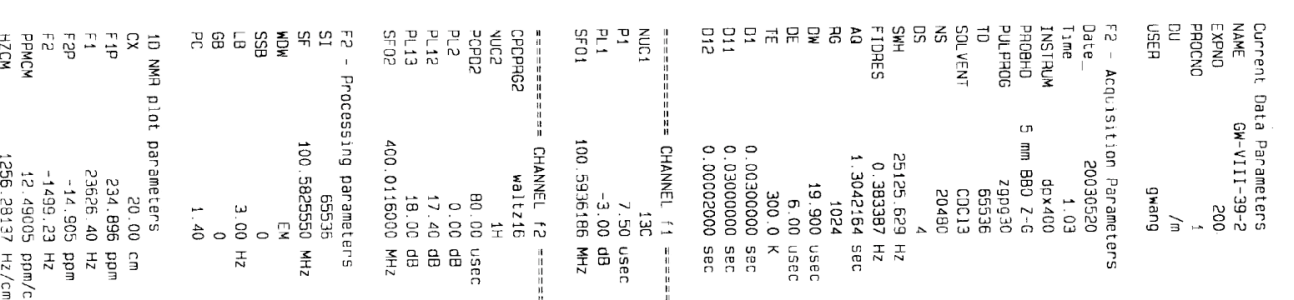

$-53.0$

51.6

39.5

r 37.5

36.1
30.1

11) -26.8

26.0

$-22.3$

- 21.1

$-19.3$

$-15.9$

$-13.0$

11.6

L 4.5

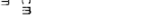

倠 


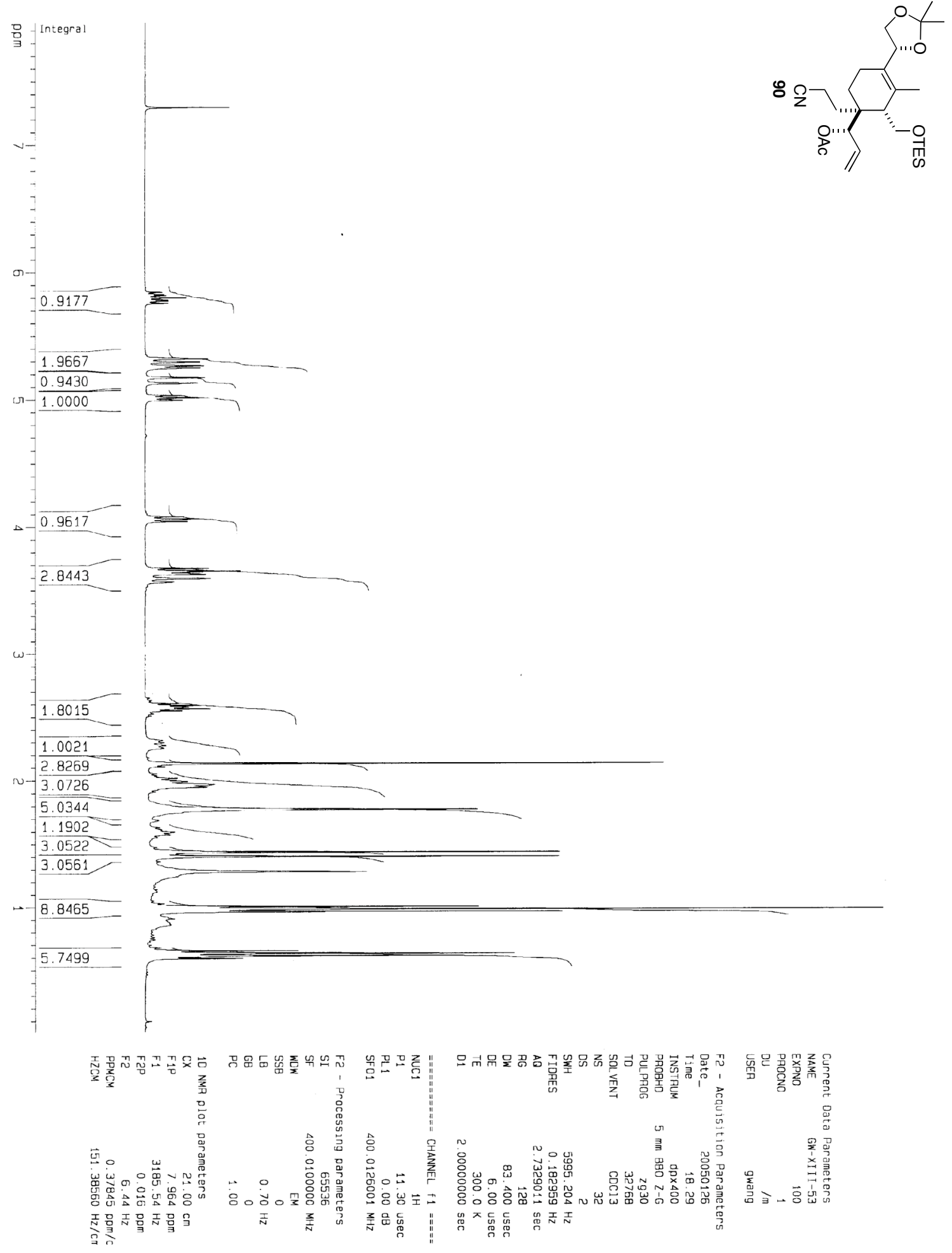



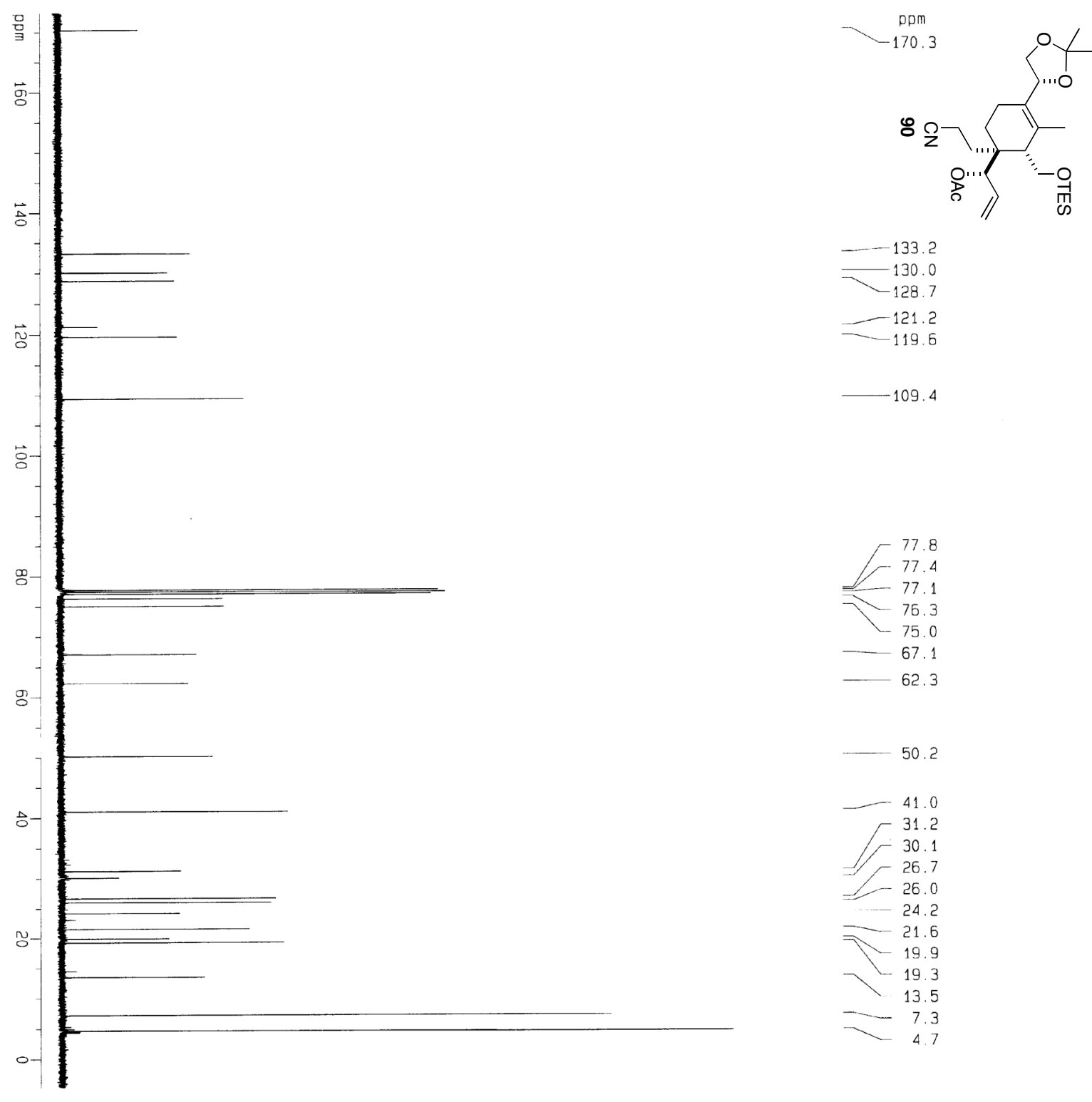

109.4
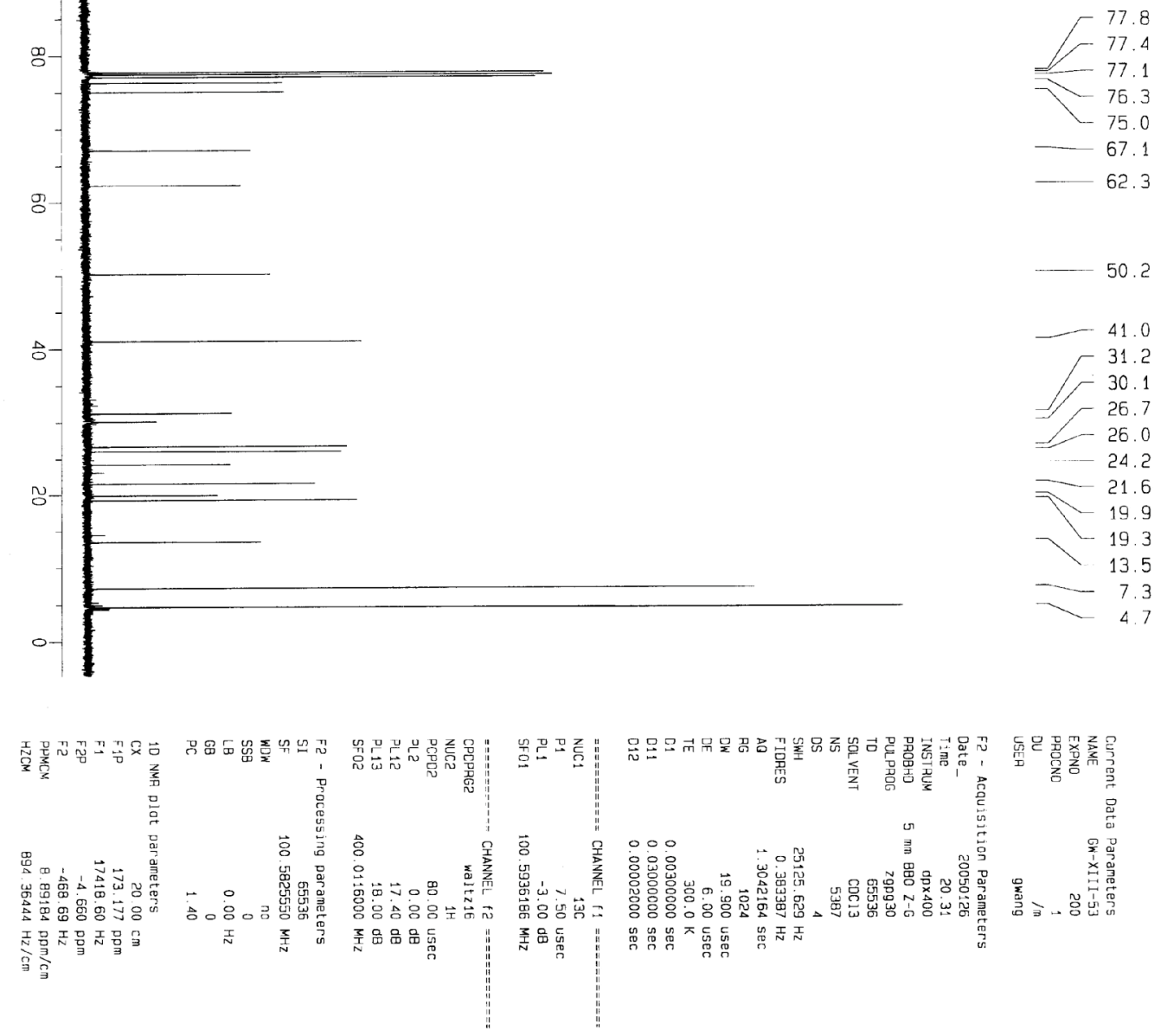


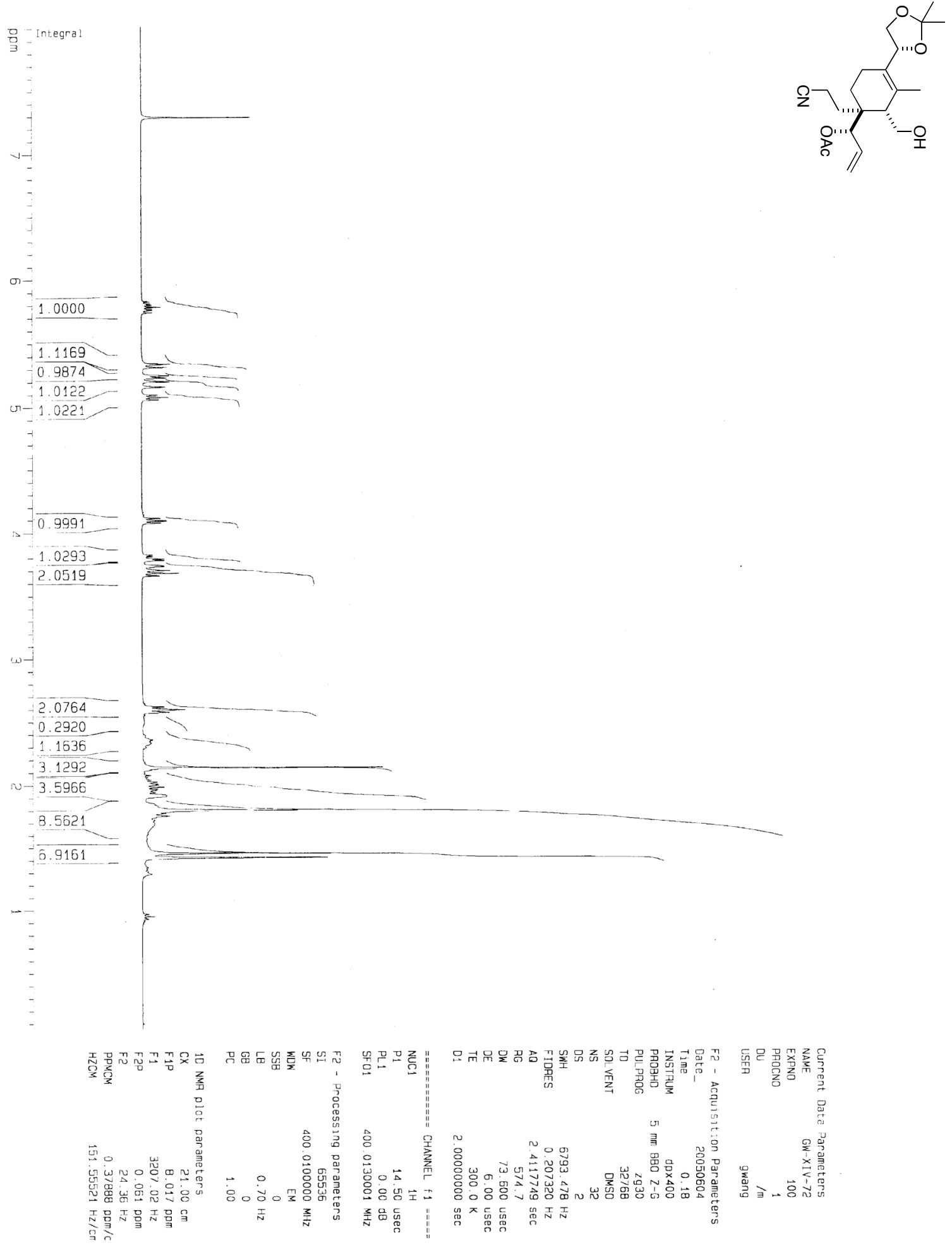




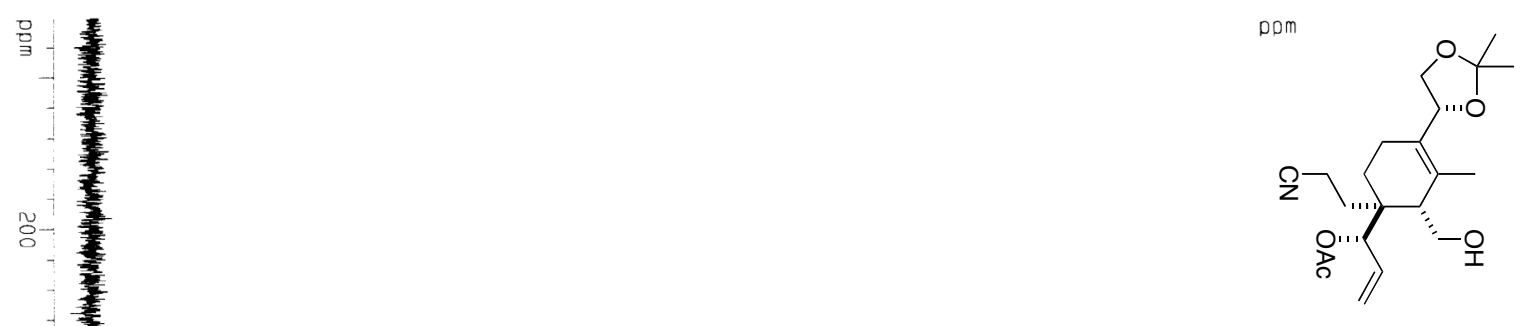

它

讪

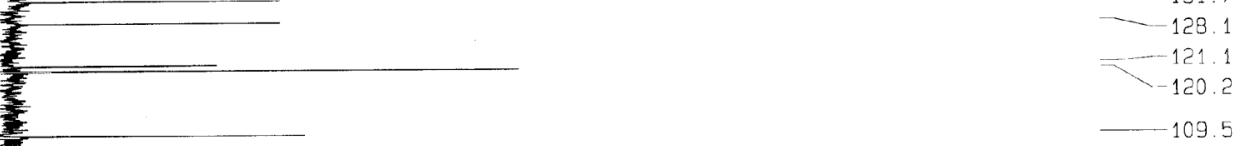

官-
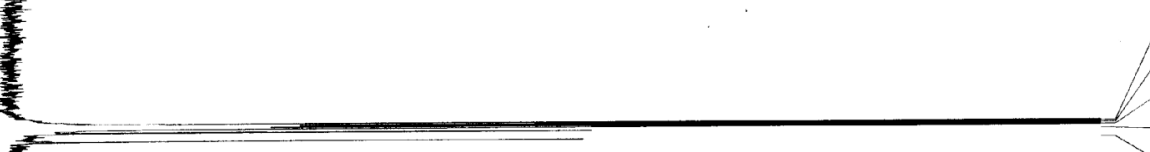

77.8
-77

77.4
-77.1

$\simeq 75.0$

- 67.1

$-49.5$

40.8

31.1

$/ 5$ 30.4

$-26.7$

$=20.0$

$1-2$

L 19.8

L 18.8

$\checkmark \begin{array}{r}13.3 \\ -4.3\end{array}$

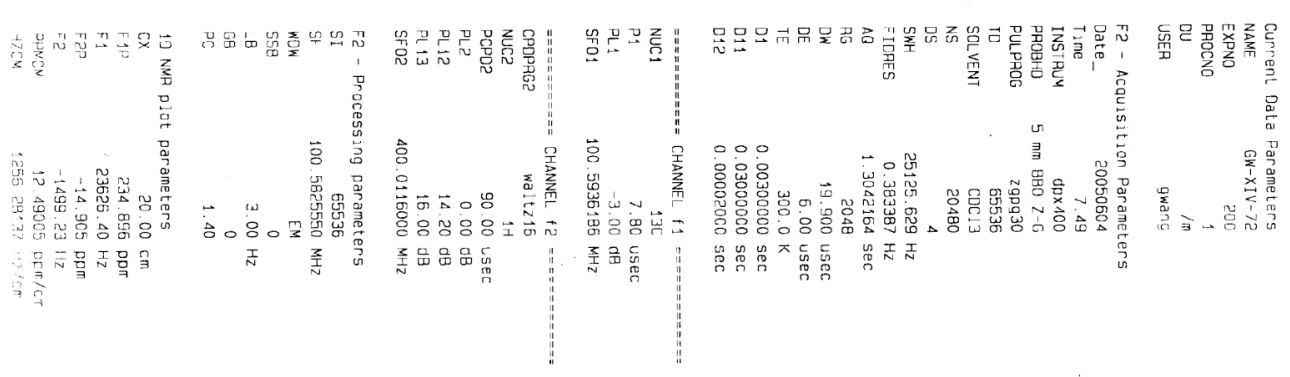




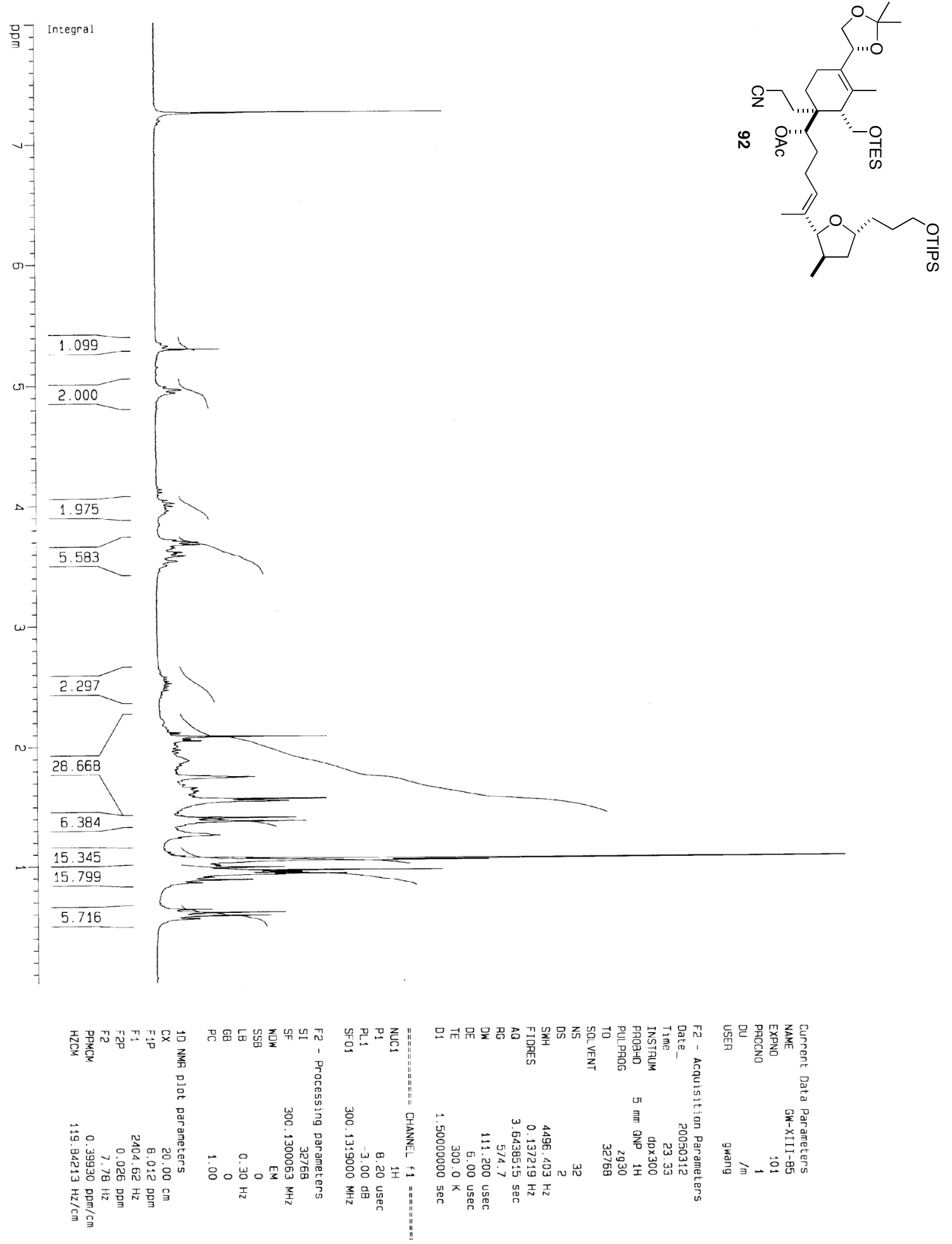



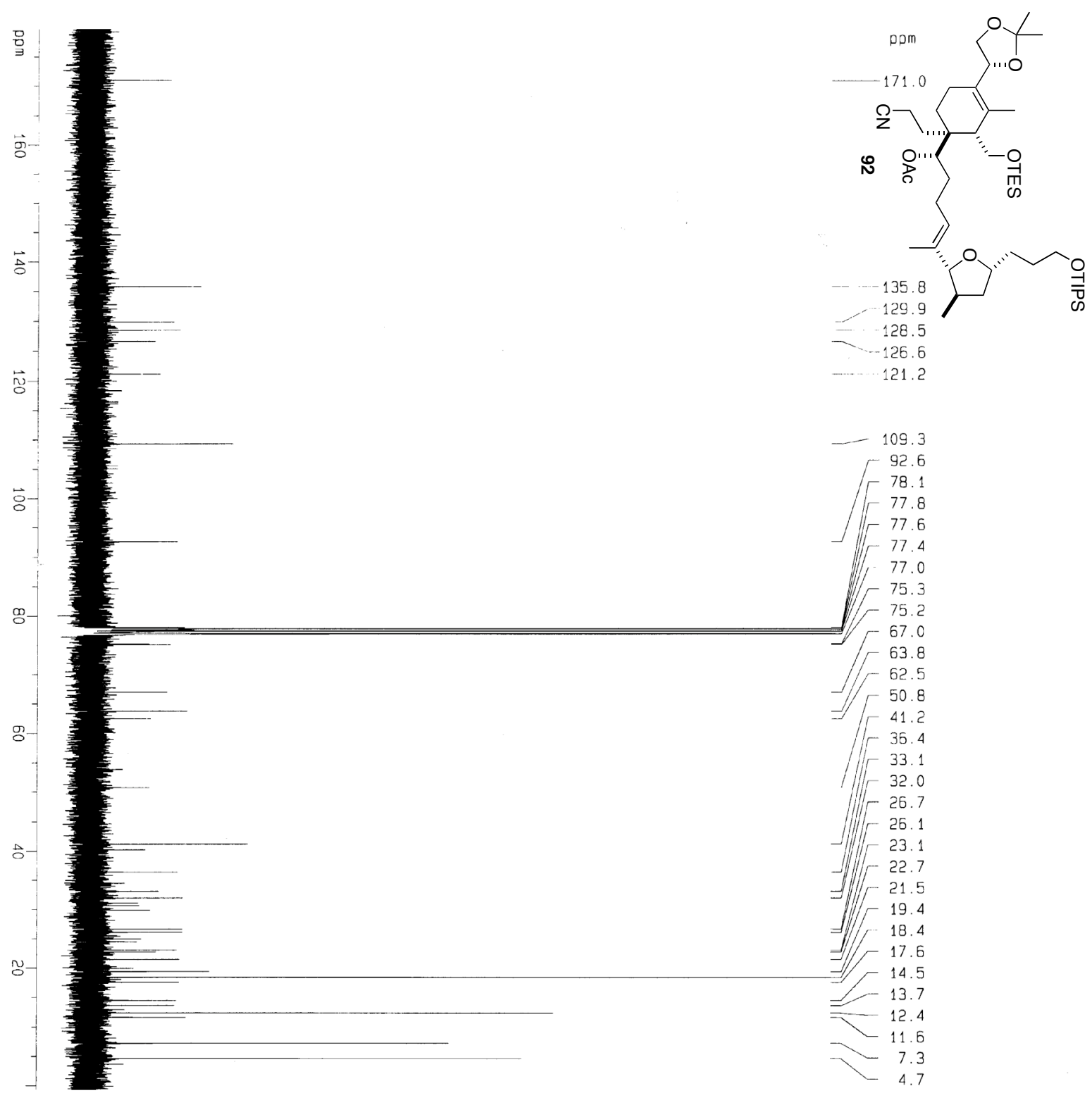

_ 109.3

r 92.6

/ 78.1

$\int 77.8$

] 77.4

77.0

If 75.3

$-75.2$

$-67.0$

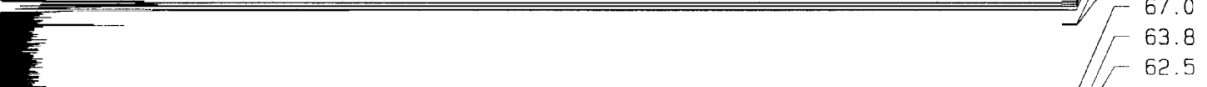

$-62.5$

C 54.2

1F 35

$\sqrt{1}-33.1$

III 32.0

$111-26.7$

IIII -26.1

-111) -23.1

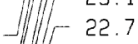

IIf 21.5

III 19.4

Jif) 18.4

17.6
-14.5

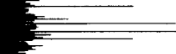

13.7

12.4
-11.6

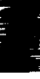

$-7.3$

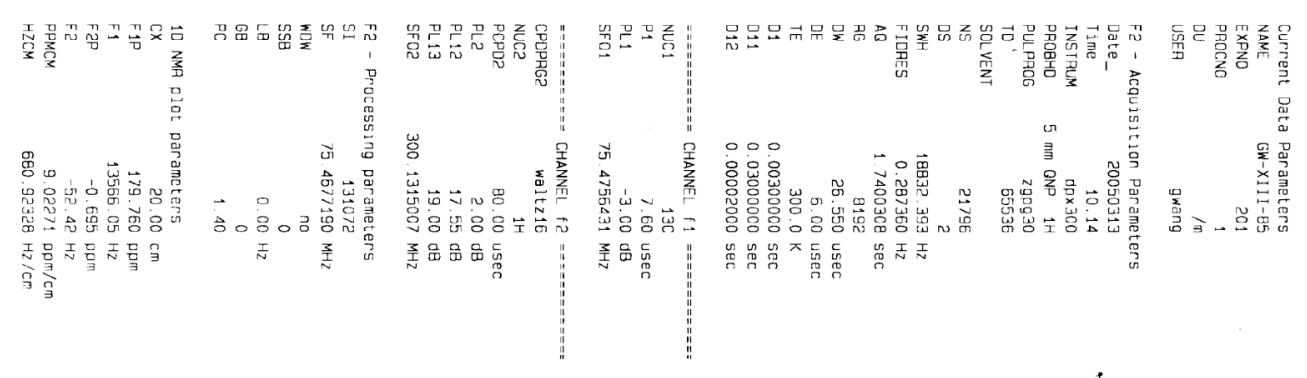




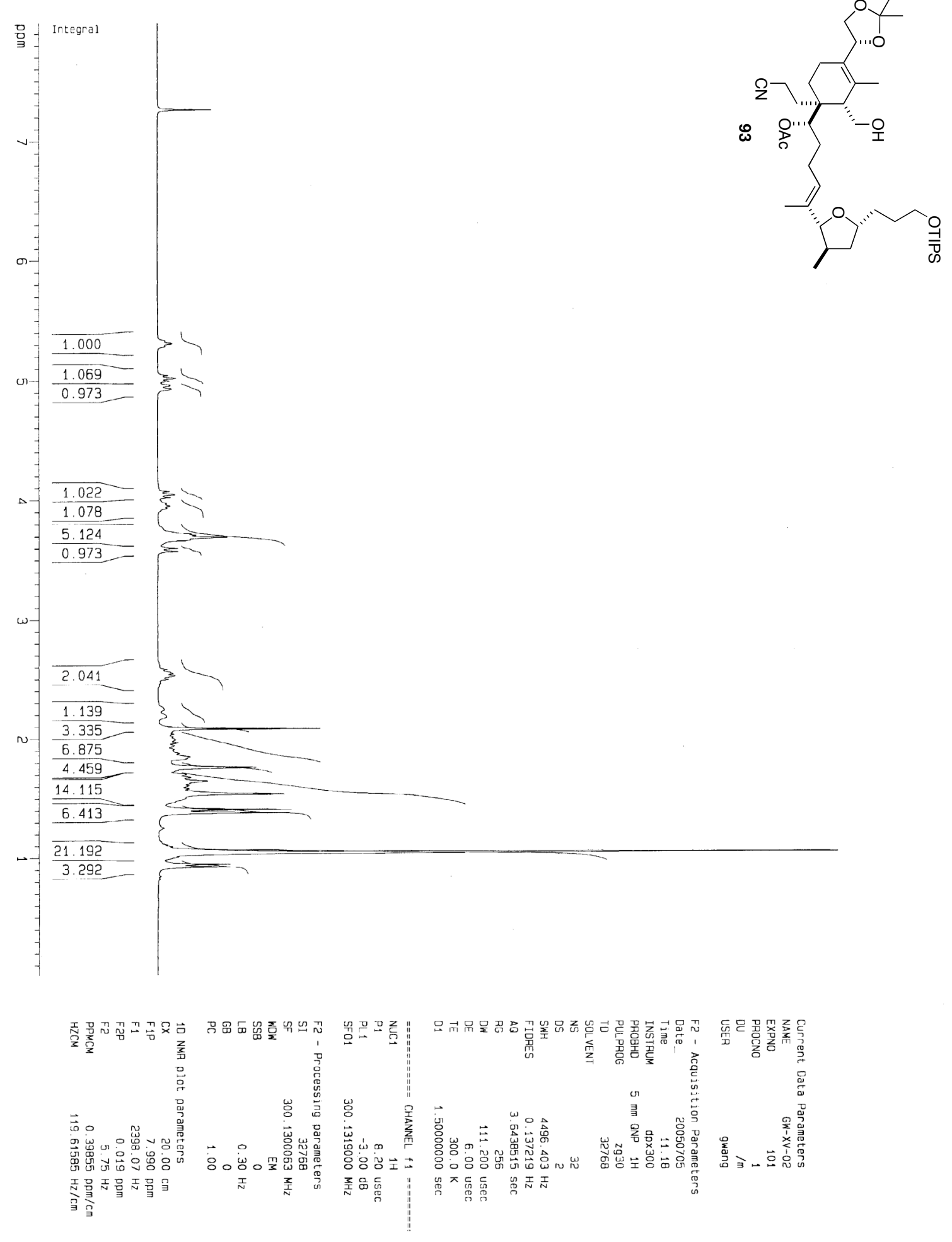




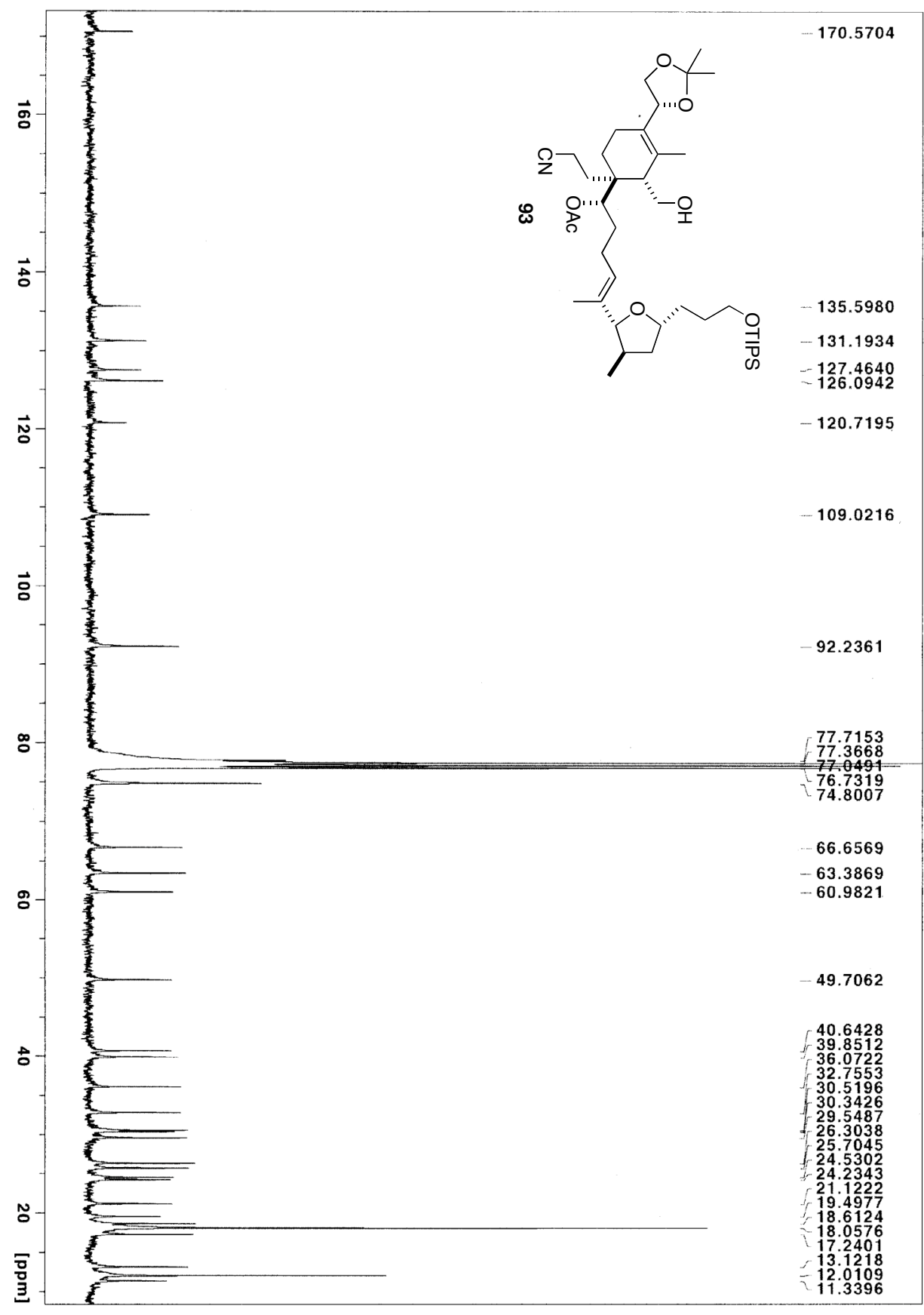



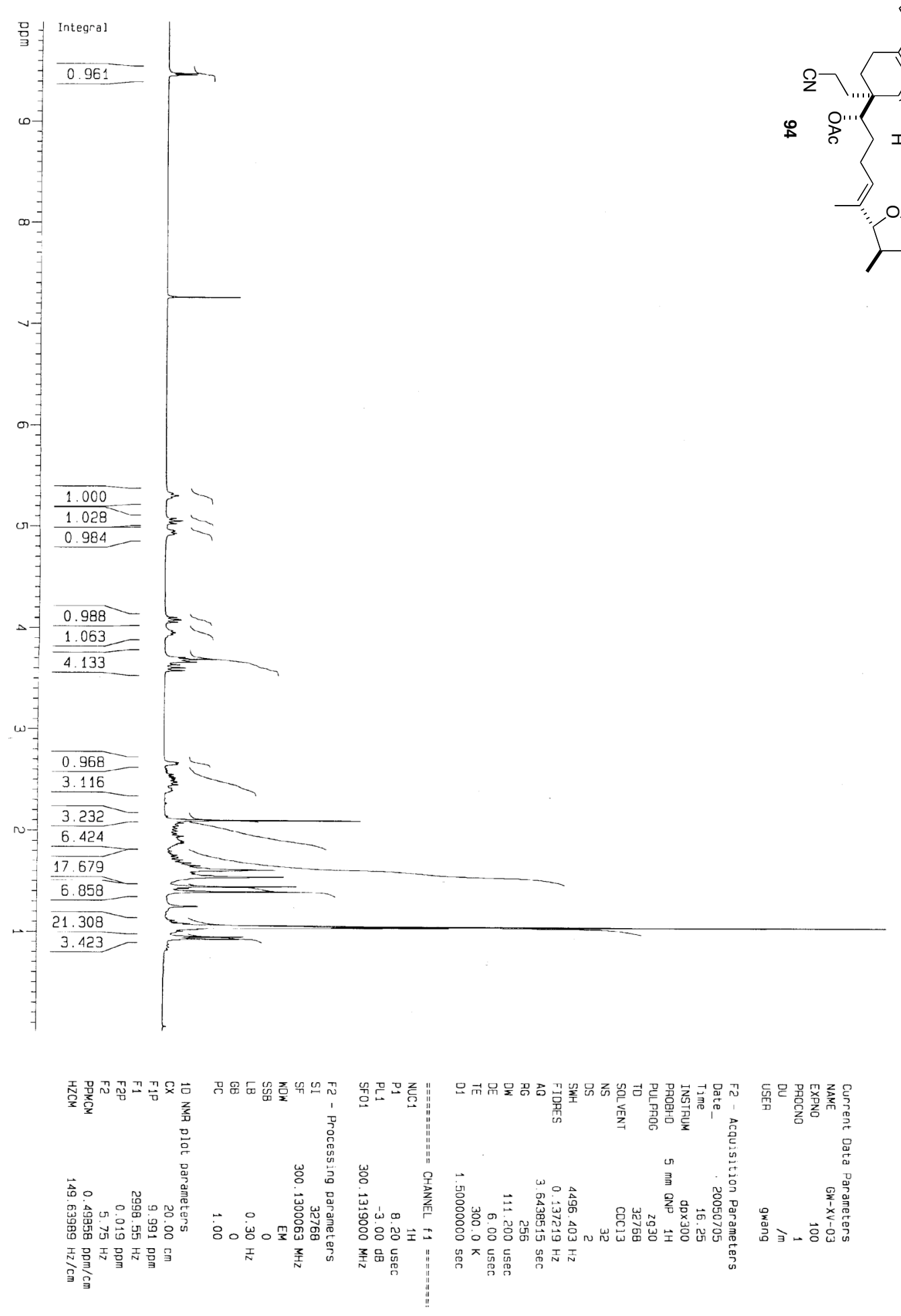


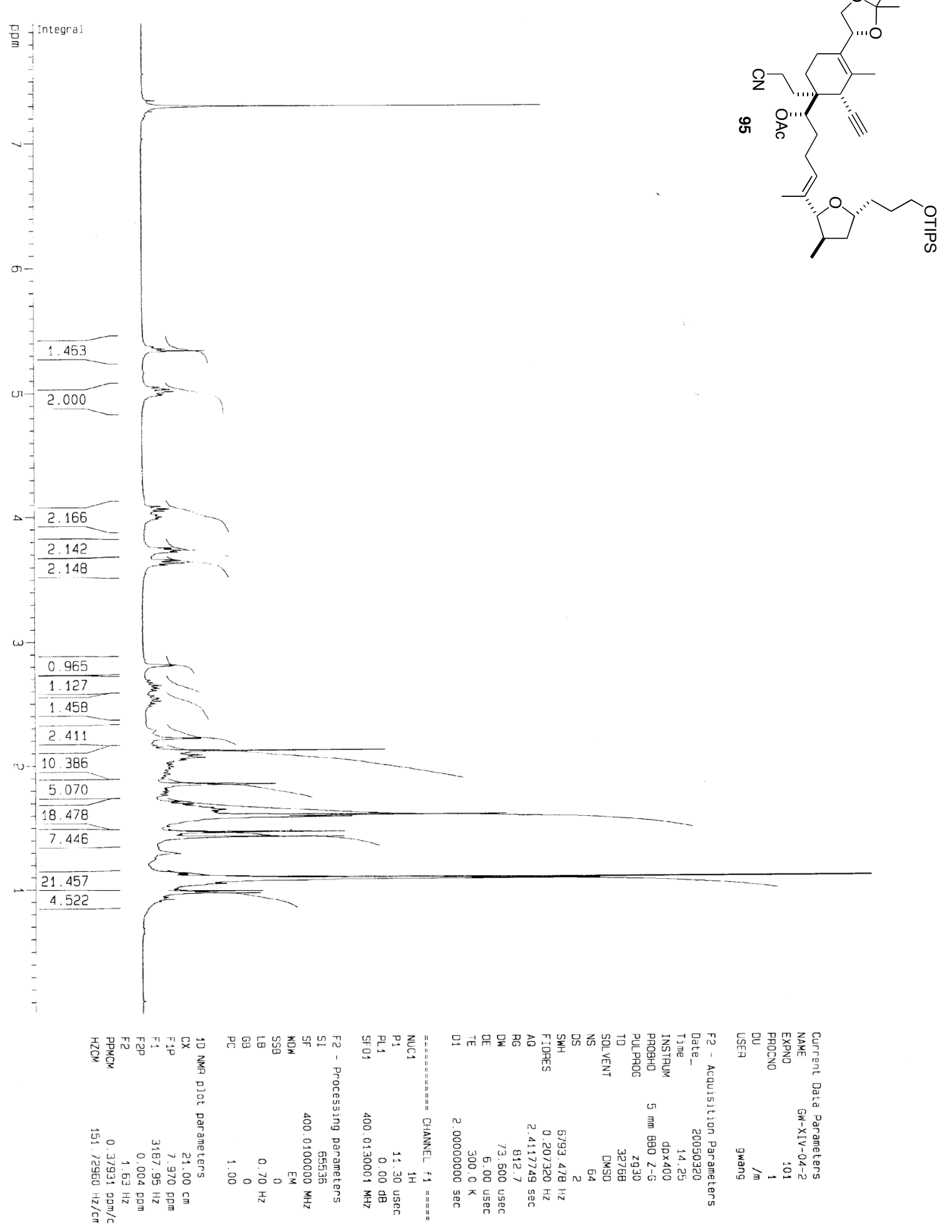


ㅇ

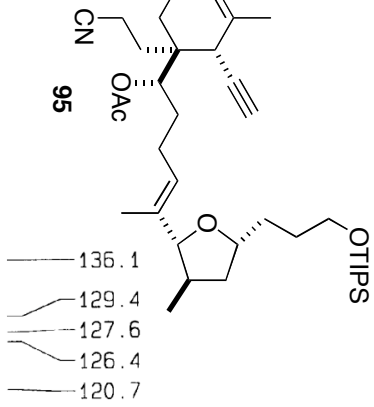

ㄱ.

$-109.6$

r 92.6

82.8

$1 / 58.1$

1If 77.7

$11-77.6$

III -77.4

- 77.1

75.1

果

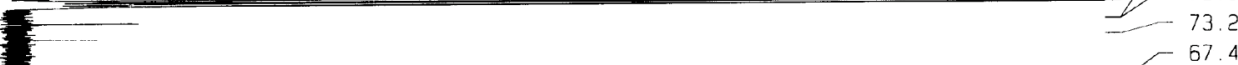

$-67.4$

63.8

41.1

IF 41.0

IIF 36.5

III 29.9

VII 26

$=\int F^{26.7} 26.0$

1) 21.4

1/I 18.5

1) 18.5

$=18.4$

$-18.4$

ㅁ-

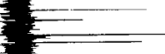

C

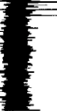

$=17.6$

$-13.3$

12.4
11.7

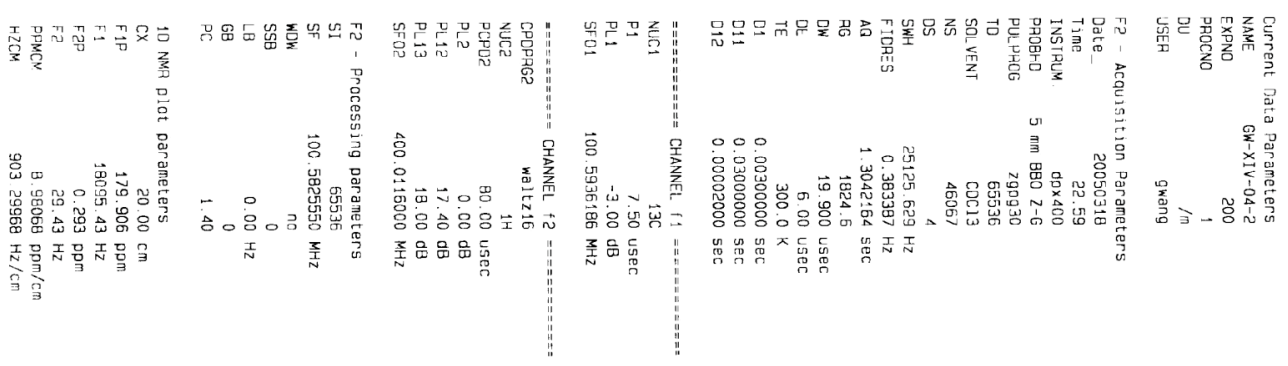




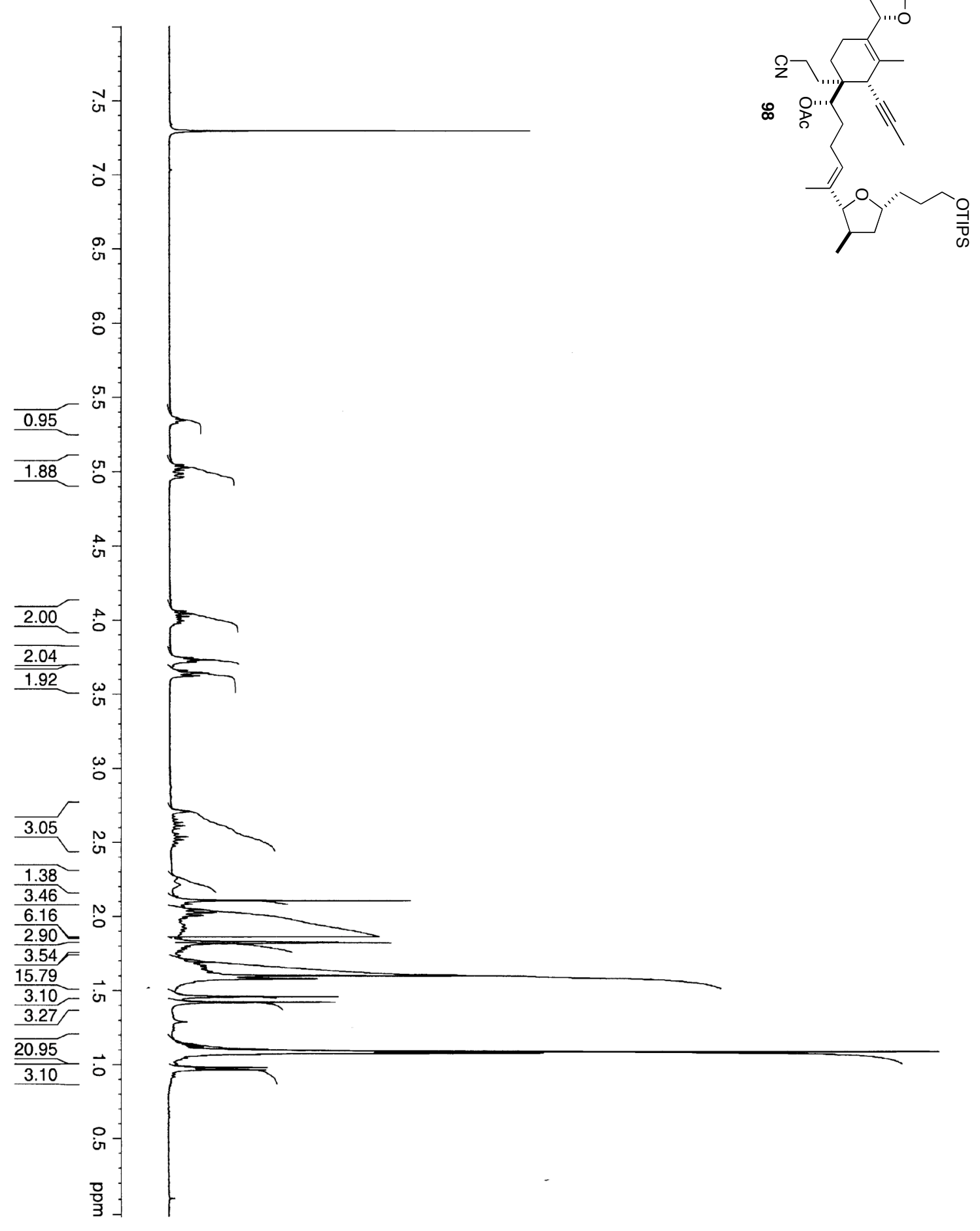




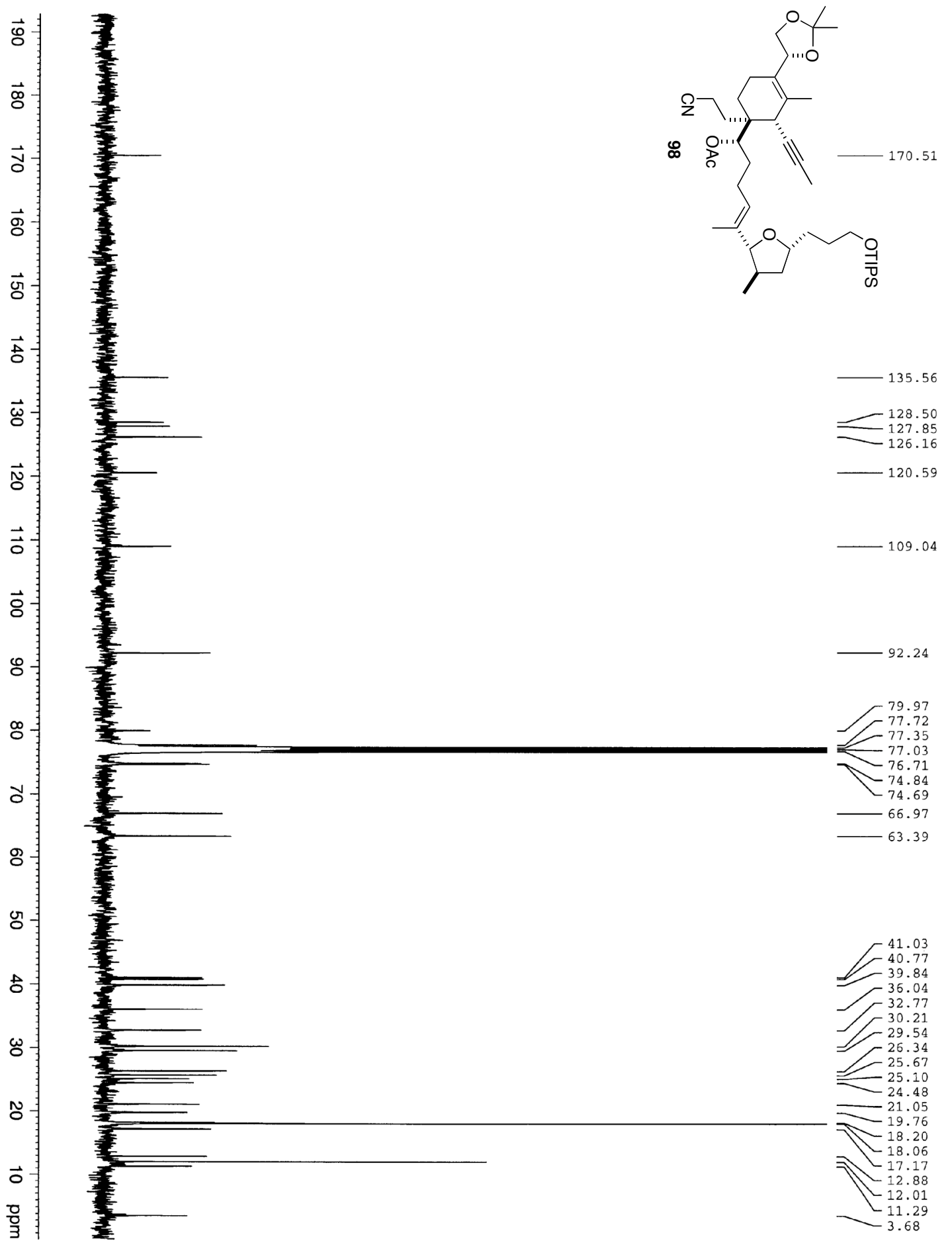


Table A1. Crystal data and structure refinement for 19 .

Identification code

Empirical formula

Formula weight

Temperature

Wavelength

Crystal system

Space group

Unit cell dimensions

Volume

Z

Density (calculated)

Absorption coefficient

$\mathrm{F}(000)$

Crystal size

Theta range for data collection

Index ranges

Reflections collected

Independent reflections

Completeness to theta $=67.69^{\circ}$

Absorption correction

Max. and min. transmission

Refinement method

Data / restraints / parameters

Goodness-of-fit on $\mathrm{F}^{2}$

Final $\mathrm{R}$ indices $[\mathrm{I}>2 \operatorname{sigma}(\mathrm{I})]$

$\mathrm{R}$ indices (all data)

Absolute structure parameter

Extinction coefficient

Largest diff. peak and hole
19

$\mathrm{C}_{22} \mathrm{H}_{25} \mathrm{Cl}_{2} \mathrm{IO}_{4}$

551.22

293(2) K

$1.54170 \AA$

Orthorhombic

$\mathrm{P} 22_{1} 2_{1} 2_{1}$ (\#18)

$\mathrm{a}=4.987(1) \AA$

$\alpha=90^{\circ}$.

$\mathrm{b}=14.790(1) \AA$

$\beta=90^{\circ}$.

$c=32.050(3) \AA$

$\gamma=90^{\circ}$.

2363.9(5) $\AA^{3}$

4

$1.549 \mathrm{Mg} / \mathrm{m}^{3}$

$12.926 \mathrm{~mm}^{-1}$

1104.

$0.3 \times 0.02 \times 0.02 \mathrm{~mm}^{3}$

2.76 to $67.69^{\circ}$.

$-5<=\mathrm{h}<=5,-17<=\mathrm{k}<=17,-38<=\mathrm{k}<=38$

4406

$3681[\mathrm{R}(\mathrm{int})=0.0317]$

$94.7 \%$

Semi-empirical (SORTAV)

0.3434 and 0.0139

Full-matrix least-squares on $\mathrm{F}^{2}$

$3681 / 22 / 301$

0.952

$\mathrm{R} 1=0.0488, \mathrm{wR} 2=0.1297$

$\mathrm{R} 1=0.1207, \mathrm{wR} 2=0.1918$

$0.000(16)$

$0.00067(15)$

0.141 and $-0.190 \mathrm{e} . \AA^{-3}$ 
Table A2. Atomic coordinates ( $\times 10^{4}$ ) and equivalent isotropic displacement parameters $\left(\AA^{2} \mathrm{x} 10^{3}\right)$ for 19 . U(eq) is defined as one third of the trace of the orthogonalized $\mathrm{U}^{\mathrm{ij}}$ tensor.

\begin{tabular}{|c|c|c|c|c|}
\hline & $\mathrm{x}$ & $\mathrm{y}$ & $\mathrm{z}$ & $\mathrm{U}(\mathrm{eq})$ \\
\hline $\mathrm{Cl}(1)$ & $173(11)$ & $4542(3)$ & $7825(1)$ & $229(2)$ \\
\hline $\mathrm{Cl}(2)$ & $-6081(11)$ & $7256(3)$ & $7253(1)$ & $248(2)$ \\
\hline$C(1)$ & $-2980(30)$ & $5118(7)$ & $5208(3)$ & $201(5)$ \\
\hline$C(2)$ & $-2640(20)$ & $4747(6)$ & $5641(3)$ & $148(3)$ \\
\hline$C(3)$ & $-1280(30)$ & $5302(8)$ & $5965(3)$ & $152(4)$ \\
\hline$C(4)$ & $-470(30)$ & $4582(8)$ & $6296(3)$ & $176(4)$ \\
\hline$C(5)$ & $-2370(30)$ & $4507(7)$ & $6650(3)$ & 171(4) \\
\hline$O(21)$ & $-360(150)$ & $3725(10)$ & $6098(4)$ & $193(5)$ \\
\hline$C(61)$ & $-1340(40)$ & $3814(10)$ & $5676(4)$ & $189(8)$ \\
\hline$C(71)$ & $-3470(50)$ & $3103(11)$ & $5582(5)$ & $210(9)$ \\
\hline $\mathrm{I}(1)$ & $-1997(4)$ & $1744(1)$ & $5598(1)$ & $236(1)$ \\
\hline$O(22)$ & $-300(700)$ & $3850(40)$ & $6010(20)$ & $193(6)$ \\
\hline$C(62)$ & $-600(130)$ & $3990(40)$ & $5570(20)$ & $189(8)$ \\
\hline$C(72)$ & $-1160(180)$ & $3010(40)$ & $5440(20)$ & $209(9)$ \\
\hline $\mathrm{I}(2)$ & $-4412(16)$ & $2414(5)$ & $5806(2)$ & $239(4)$ \\
\hline$C(11)$ & $1890(30)$ & $6499(8)$ & 5993(4) & $178(4)$ \\
\hline$C(12)$ & $0(30)$ & $7284(8)$ & $5951(5)$ & $168(4)$ \\
\hline$C(13)$ & $-1480(30)$ & $7593(9)$ & 6283(4) & $182(5)$ \\
\hline$C(14)$ & $-3260(30)$ & $8319(8)$ & $6243(4)$ & $165(4)$ \\
\hline$C(15)$ & $-3470(30)$ & $8706(9)$ & $5862(4)$ & $170(5)$ \\
\hline$C(16)$ & $-2180(30)$ & $8399(9)$ & $5523(4)$ & $180(5)$ \\
\hline $\mathrm{C}(17)$ & $-410(30)$ & $7696(10)$ & $5567(4)$ & $185(5)$ \\
\hline$C(18)$ & $-6760(30)$ & $9758(8)$ & $6111(4)$ & $197(5)$ \\
\hline$C(21)$ & $-3940(30)$ & 5293(9) & $7235(3)$ & $188(5)$ \\
\hline$C(22)$ & $-2950(40)$ & 5927(9) & $7568(3)$ & $172(4)$ \\
\hline$C(23)$ & $-1000(30)$ & $5642(9)$ & $7859(5)$ & $184(5)$ \\
\hline$C(24)$ & $-160(50)$ & $6196(13)$ & $8163(4)$ & $232(8)$ \\
\hline$C(25)$ & $-980(50)$ & $7062(12)$ & $8193(5)$ & $232(9)$ \\
\hline$C(26)$ & $-2930(40)$ & $7382(11)$ & $7916(5)$ & $215(7)$ \\
\hline$C(27)$ & $-3760(30)$ & $6806(11)$ & $7602(4)$ & $177(4)$ \\
\hline $\mathrm{O}(1)$ & $950(20)$ & $5696(5)$ & $5776(3)$ & $175(3)$ \\
\hline
\end{tabular}




\begin{tabular}{lllll}
$\mathrm{O}(3)$ & $-2007(19)$ & $5280(5)$ & $6901(2)$ & $174(3)$ \\
$\mathrm{O}(4)$ & $-5130(20)$ & $9428(7)$ & $5779(3)$ & $195(3)$ \\
\hline
\end{tabular}


Table A3. Bond lengths $[\AA]$ and angles [0] for 19.

\begin{tabular}{|c|c|c|c|}
\hline $\mathrm{Cl}(1)-\mathrm{C}(23)$ & $1.733(14)$ & $C(25)-C(26)$ & $1.40(2)$ \\
\hline $\mathrm{Cl}(2)-\mathrm{C}(27)$ & $1.740(13)$ & $C(26)-C(27)$ & $1.383(19)$ \\
\hline$C(1)-C(2)$ & $1.503(11)$ & & \\
\hline$C(2)-C(3)$ & $1.488(13)$ & $C(3)-C(2)-C(1)$ & $119.7(9)$ \\
\hline$C(2)-C(61)$ & $1.529(15)$ & $C(3)-C(2)-C(61)$ & $104.6(10)$ \\
\hline$C(2)-C(62)$ & $1.529(16)$ & $C(1)-C(2)-C(61)$ & $116.5(9)$ \\
\hline $\mathrm{C}(3)-\mathrm{O}(1)$ & $1.392(13)$ & $C(3)-C(2)-C(62)$ & $102(3)$ \\
\hline$C(3)-C(4)$ & $1.555(14)$ & $C(1)-C(2)-C(62)$ & $101(3)$ \\
\hline$C(4)-O(21)$ & $1.420(12)$ & $C(61)-C(2)-C(62)$ & $22(3)$ \\
\hline$C(4)-O(22)$ & $1.420(14)$ & $\mathrm{O}(1)-\mathrm{C}(3)-\mathrm{C}(2)$ & $106.9(9)$ \\
\hline$C(4)-C(5)$ & $1.483(15)$ & $\mathrm{O}(1)-\mathrm{C}(3)-\mathrm{C}(4)$ & $112.2(11)$ \\
\hline$C(5)-O(3)$ & $1.409(11)$ & $C(2)-C(3)-C(4)$ & $102.5(9)$ \\
\hline $\mathrm{O}(21)-\mathrm{C}(61)$ & $1.44(2)$ & $\mathrm{O}(21)-\mathrm{C}(4)-\mathrm{O}(22)$ & $14(5)$ \\
\hline$C(61)-C(71)$ & $1.53(2)$ & $\mathrm{O}(21)-\mathrm{C}(4)-\mathrm{C}(5)$ & $107(3)$ \\
\hline $\mathrm{C}(71)-\mathrm{I}(1)$ & $2.141(15)$ & $\mathrm{O}(22)-\mathrm{C}(4)-\mathrm{C}(5)$ & $118(10)$ \\
\hline$O(22)-C(62)$ & $1.44(2)$ & $\mathrm{O}(21)-\mathrm{C}(4)-\mathrm{C}(3)$ & $108.4(11)$ \\
\hline$C(62)-C(72)$ & $1.53(2)$ & $\mathrm{O}(22)-\mathrm{C}(4)-\mathrm{C}(3)$ & $95(4)$ \\
\hline $\mathrm{C}(72)-\mathrm{I}(2)$ & $2.18(8)$ & $C(5)-C(4)-C(3)$ & $114.1(11)$ \\
\hline $\mathrm{C}(11)-\mathrm{O}(1)$ & $1.456(12)$ & $\mathrm{O}(3)-\mathrm{C}(5)-\mathrm{C}(4)$ & $107.0(10)$ \\
\hline$C(11)-C(12)$ & $1.503(16)$ & $\mathrm{C}(4)-\mathrm{O}(21)-\mathrm{C}(61)$ & $108.9(16)$ \\
\hline$C(12)-C(13)$ & $1.373(17)$ & $\mathrm{O}(21)-\mathrm{C}(61)-\mathrm{C}(71)$ & $111(2)$ \\
\hline$C(12)-C(17)$ & $1.387(16)$ & $\mathrm{O}(21)-\mathrm{C}(61)-\mathrm{C}(2)$ & $107.2(14)$ \\
\hline$C(13)-C(14)$ & $1.398(16)$ & $C(71)-C(61)-C(2)$ & $108.1(15)$ \\
\hline$C(14)-C(15)$ & $1.352(14)$ & $\mathrm{C}(61)-\mathrm{C}(71)-\mathrm{I}(1)$ & $113.8(13)$ \\
\hline$C(15)-C(16)$ & $1.340(16)$ & $\mathrm{C}(4)-\mathrm{O}(22)-\mathrm{C}(62)$ & $121(5)$ \\
\hline$C(15)-O(4)$ & $1.377(14)$ & $\mathrm{O}(22)-\mathrm{C}(62)-\mathrm{C}(72)$ & $98(6)$ \\
\hline$C(16)-C(17)$ & $1.372(16)$ & $\mathrm{O}(22)-\mathrm{C}(62)-\mathrm{C}(2)$ & $91(10)$ \\
\hline$C(18)-O(4)$ & $1.424(13)$ & $\mathrm{C}(72)-\mathrm{C}(62)-\mathrm{C}(2)$ & $\cdot 128(6)$ \\
\hline $\mathrm{C}(21)-\mathrm{O}(3)$ & $1.440(13)$ & $\mathrm{C}(62)-\mathrm{C}(72)-\mathrm{I}(2)$ & $113(5)$ \\
\hline$C(21)-C(22)$ & $1.502(15)$ & $\mathrm{O}(1)-\mathrm{C}(11)-\mathrm{C}(12)$ & $112.5(10)$ \\
\hline$C(22)-C(27)$ & $1.366(16)$ & $C(13)-C(12)-C(17)$ & $117.5(14)$ \\
\hline$C(22)-C(23)$ & $1.412(18)$ & $\mathrm{C}(13)-\mathrm{C}(12)-\mathrm{C}(11)$ & $121.7(14)$ \\
\hline$C(23)-C(24)$ & $1.340(17)$ & $C(17)-C(12)-C(11)$ & $120.7(15)$ \\
\hline$C(24)-C(25)$ & $1.35(2)$ & $C(12)-C(13)-C(14)$ & $121.6(12)$ \\
\hline
\end{tabular}




$\begin{array}{llll}\mathrm{C}(15)-\mathrm{C}(14)-\mathrm{C}(13) & 117.3(12) & \mathrm{C}(24)-\mathrm{C}(23)-\mathrm{Cl}(1) & 120.9(16) \\ \mathrm{C}(16)-\mathrm{C}(15)-\mathrm{C}(14) & 123.3(14) & \mathrm{C}(22)-\mathrm{C}(23)-\mathrm{Cl}(1) & 118.2(12) \\ \mathrm{C}(16)-\mathrm{C}(15)-\mathrm{O}(4) & 113.3(13) & \mathrm{C}(23)-\mathrm{C}(24)-\mathrm{C}(25) & 123(2) \\ \mathrm{C}(14)-\mathrm{C}(15)-\mathrm{O}(4) & 123.3(14) & \mathrm{C}(24)-\mathrm{C}(25)-\mathrm{C}(26) & 119.1(19) \\ \mathrm{C}(15)-\mathrm{C}(16)-\mathrm{C}(17) & 118.9(13) & \mathrm{C}(27)-\mathrm{C}(26)-\mathrm{C}(25) & 117.6(16) \\ \mathrm{C}(16)-\mathrm{C}(17)-\mathrm{C}(12) & 121.2(14) & \mathrm{C}(22)-\mathrm{C}(27)-\mathrm{C}(26) & 123.7(14) \\ \mathrm{O}(3)-\mathrm{C}(21)-\mathrm{C}(22) & 108.6(11) & \mathrm{C}(22)-\mathrm{C}(27)-\mathrm{Cl}(2) & 120.6(13) \\ \mathrm{C}(27)-\mathrm{C}(22)-\mathrm{C}(23) & 115.8(12) & \mathrm{C}(26)-\mathrm{C}(27)-\mathrm{Cl}(2) & 115.6(14) \\ \mathrm{C}(27)-\mathrm{C}(22)-\mathrm{C}(21) & 123.7(16) & \mathrm{C}(3)-\mathrm{O}(1)-\mathrm{C}(11) & 113.0(9) \\ \mathrm{C}(23)-\mathrm{C}(22)-\mathrm{C}(21) & 120.5(14) & \mathrm{C}(5)-\mathrm{O}(3)-\mathrm{C}(21) & 110.4(9) \\ \mathrm{C}(24)-\mathrm{C}(23)-\mathrm{C}(22) & 120.9(15) & \mathrm{C}(15)-\mathrm{O}(4)-\mathrm{C}(18) & 117.6(11)\end{array}$

Symmetry transformations used to generate equivalent atoms: 
Table A4. Anisotropic displacement parameters $\left(\AA^{2} \times 10^{3}\right)$ for 19. The anisotropic displacement factor exponent takes the form: $-2 \pi^{2}\left[h^{2} a^{* 2} U^{11}+\ldots+2 h k a^{*} b^{*} U^{12}\right]$

\begin{tabular}{|c|c|c|c|c|c|c|}
\hline & $\mathrm{U}^{11}$ & $\mathrm{U}^{22}$ & $\mathrm{U}^{33}$ & $U^{23}$ & $\mathrm{U}^{13}$ & $U^{12}$ \\
\hline $\mathrm{Cl}(1)$ & $323(5)$ & $176(3)$ & $187(3)$ & $26(2)$ & $13(3)$ & 28(3) \\
\hline $\mathrm{Cl}(2)$ & $300(5)$ & $240(4)$ & $206(3)$ & $45(3)$ & 29(3) & $54(4)$ \\
\hline$C(1)$ & $303(16)$ & $163(9)$ & $137(7)$ & $19(6)$ & $-36(10)$ & $10(12)$ \\
\hline$C(2)$ & $191(9)$ & $128(6)$ & $124(6)$ & $-7(5)$ & $-27(8)$ & $3(7)$ \\
\hline$C(3)$ & $192(11)$ & $138(8)$ & $125(7)$ & $2(6)$ & $11(8)$ & $30(8)$ \\
\hline$C(4)$ & $259(13)$ & $141(8)$ & $127(7)$ & $-7(7)$ & $12(9)$ & $35(10)$ \\
\hline$C(5)$ & $230(11)$ & $139(7)$ & $144(7)$ & $-8(6)$ & $-10(10)$ & $7(10)$ \\
\hline $\mathrm{O}(21)$ & $307(11)$ & $145(7)$ & $127(8)$ & $-3(7)$ & $-18(19)$ & $61(14)$ \\
\hline$C(61)$ & $320(20)$ & $137(11)$ & $105(12)$ & $17(7)$ & $10(12)$ & $5(13)$ \\
\hline$C(71)$ & $330(30)$ & $145(11)$ & $152(12)$ & $26(11)$ & $3(17)$ & $51(18)$ \\
\hline $\mathrm{I}(1)$ & $412(2)$ & $139(1)$ & $158(1)$ & $-7(1)$ & $-8(1)$ & $39(1)$ \\
\hline $\mathrm{O}(22)$ & $306(11)$ & $144(9)$ & $129(9)$ & $-2(8)$ & $-20(20)$ & $61(15)$ \\
\hline$C(62)$ & $320(20)$ & $138(12)$ & $104(13)$ & $18(9)$ & $8(13)$ & $5(14)$ \\
\hline$C(72)$ & $330(30)$ & $145(12)$ & $152(13)$ & $25(12)$ & $4(18)$ & $51(19)$ \\
\hline $\mathrm{I}(2)$ & $309(7)$ & $190(6)$ & $217(5)$ & 1(4) & $33(5)$ & $-41(5)$ \\
\hline $\mathrm{C}(11)$ & $188(11)$ & $163(10)$ & $184(10)$ & $-22(8)$ & $-18(9)$ & $-10(10)$ \\
\hline$C(12)$ & $203(12)$ & $124(8)$ & $177(11)$ & $-16(8)$ & $-18(11)$ & $-4(9)$ \\
\hline$C(13)$ & $259(15)$ & $134(8)$ & $154(9)$ & $-8(7)$ & $-7(10)$ & $11(11)$ \\
\hline$C(14)$ & $213(12)$ & $133(8)$ & $149(8)$ & $-7(7)$ & $16(8)$ & $-3(10)$ \\
\hline$C(15)$ & 231(14) & $132(8)$ & $147(9)$ & $16(7)$ & $11(10)$ & $-2(10)$ \\
\hline$C(16)$ & $233(14)$ & $160(10)$ & $148(9)$ & $5(8)$ & $23(11)$ & $7(11)$ \\
\hline$C(17)$ & $217(13)$ & $169(11)$ & $169(11)$ & $-2(10)$ & $32(11)$ & $4(11)$ \\
\hline $\mathrm{C}(18)$ & $247(15)$ & $147(9)$ & $198(11)$ & $-19(8)$ & $10(11)$ & $26(11)$ \\
\hline$C(21)$ & $251(14)$ & $181(10)$ & $131(7)$ & $-23(8)$ & $16(9)$ & $-27(11)$ \\
\hline $\mathrm{C}(22)$ & $255(14)$ & $139(9)$ & $123(7)$ & $-14(6)$ & $14(10)$ & $-21(11)$ \\
\hline$C(23)$ & $255(15)$ & $152(10)$ & $147(9)$ & $-2(8)$ & $23(10)$ & $-23(11)$ \\
\hline $\mathrm{C}(24)$ & $360(20)$ & $212(15)$ & $124(8)$ & $-10(10)$ & $-9(12)$ & $-63(19)$ \\
\hline$C(25)$ & $350(30)$ & $176(15)$ & $166(13)$ & $-37(11)$ & $50(15)$ & $-53(17)$ \\
\hline$C(26)$ & $300(20)$ & $168(12)$ & $174(12)$ & $-8(11)$ & $25(15)$ & $3(15)$ \\
\hline$C(27)$ & $238(13)$ & $161(10)$ & $131(8)$ & $13(8)$ & $8(8)$ & $0(12)$ \\
\hline$O(1)$ & $209(8)$ & $147(6)$ & $169(6)$ & $-26(5)$ & $10(6)$ & $2(6)$ \\
\hline
\end{tabular}




\begin{tabular}{lllllll}
$\mathrm{O}(3)$ & $249(8)$ & $141(5)$ & $133(5)$ & $-16(4)$ & $18(6)$ & $-5(7)$ \\
$\mathrm{O}(4)$ & $258(9)$ & $157(6)$ & $169(7)$ & $14(6)$ & $22(7)$ & $8(7)$ \\
\hline
\end{tabular}


Table A5. Hydrogen coordinate $\left(\times 10^{4}\right)$ and isotropic displacement parameter $\left(\AA^{2} \times 10^{3}\right)$ for 19 .

\begin{tabular}{|c|c|c|c|c|}
\hline & $\mathrm{x}$ & $\mathrm{y}$ & $\mathrm{z}$ & $\mathrm{U}(\mathrm{eq})$ \\
\hline $\mathrm{H}(1 \mathrm{~A})$ & -4040 & 4706 & 5045 & 302 \\
\hline $\mathrm{H}(1 \mathrm{~B})$ & -1257 & 5193 & 5080 & 302 \\
\hline $\mathrm{H}(1 \mathrm{C})$ & -3876 & 5693 & 5222 & 302 \\
\hline$H(2)$ & -4470 & 4664 & 5746 & 177 \\
\hline $\mathrm{H}(3)$ & -2481 & 5759 & 6083 & 182 \\
\hline $\mathrm{H}(4)$ & 1313 & 4731 & 6405 & 211 \\
\hline $\mathrm{H}(5 \mathrm{~A})$ & -4201 & 4480 & 6548 & 205 \\
\hline $\mathrm{H}(5 \mathrm{~B})$ & -2009 & 3963 & 6810 & 205 \\
\hline $\mathrm{H}(61)$ & 149 & 3763 & 5478 & 226 \\
\hline $\mathrm{H}(71 \mathrm{~A})$ & -4215 & 3221 & 5307 & 252 \\
\hline $\mathrm{H}(71 \mathrm{~B})$ & -4912 & 3162 & 5783 & 252 \\
\hline$H(62)$ & 1059 & 4223 & 5439 & 227 \\
\hline $\mathrm{H}(72 \mathrm{~A})$ & 459 & 2659 & 5485 & 251 \\
\hline $\mathrm{H}(72 B)$ & -1614 & 2990 & 5150 & 251 \\
\hline $\mathrm{H}(11 \mathrm{~A})$ & 3629 & 6671 & 5882 & 214 \\
\hline $\mathrm{H}(11 \mathrm{~B})$ & 2124 & 6359 & 6286 & 214 \\
\hline $\mathrm{H}(13)$ & -1297 & 7313 & 6541 & 219 \\
\hline $\mathrm{H}(14)$ & -4252 & 8528 & 6469 & 198 \\
\hline$H(16)$ & -2483 & 8658 & 5263 & 216 \\
\hline $\mathrm{H}(17)$ & 538 & 7492 & 5336 & 222 \\
\hline $\mathrm{H}(18 \mathrm{~A})$ & -7851 & 10246 & 6012 & 296 \\
\hline $\mathrm{H}(18 \mathrm{~B})$ & -5628 & 9970 & 6333 & 296 \\
\hline $\mathrm{H}(18 \mathrm{C})$ & -7883 & 9280 & 6212 & 296 \\
\hline $\mathrm{H}(21 \mathrm{~A})$ & -4148 & 4690 & 7349 & 226 \\
\hline $\mathrm{H}(21 \mathrm{~B})$ & -5662 & 5494 & 7131 & 226 \\
\hline $\mathrm{H}(24)$ & 1036 & 5975 & 8360 & 279 \\
\hline $\mathrm{H}(25)$ & -264 & 7442 & 8395 & 279 \\
\hline $\mathrm{H}(26)$ & -3640 & 7961 & 7942 & 259 \\
\hline
\end{tabular}


Table A6. Torsion angles [ $\left.{ }^{\circ}\right]$ for $\mathbf{1 9}$.

\begin{tabular}{|c|c|c|c|}
\hline$C(1)-C(2)-C(3)-O(1)$ & $-42.8(14)$ & $\mathrm{C}(1)-\mathrm{C}(2)-\mathrm{C}(62)-\mathrm{O}(22)$ & $172(12)$ \\
\hline$C(61)-C(2)-C(3)-O(1)$ & $89.9(11)$ & $C(61)-C(2)-C(62)-O(22)$ & $-52(14)$ \\
\hline$C(62)-C(2)-C(3)-O(1)$ & $68(3)$ & $\mathrm{C}(3)-\mathrm{C}(2)-\mathrm{C}(62)-\mathrm{C}(72)$ & $148(6)$ \\
\hline$C(1)-C(2)-C(3)-C(4)$ & $-161.0(12)$ & $\mathrm{C}(1)-\mathrm{C}(2)-\mathrm{C}(62)-\mathrm{C}(72)$ & $-88(7)$ \\
\hline$C(61)-C(2)-C(3)-C(4)$ & $-28.3(13)$ & $\mathrm{C}(61)-\mathrm{C}(2)-\mathrm{C}(62)-\mathrm{C}(72)$ & $49(8)$ \\
\hline$C(62)-C(2)-C(3)-C(4)$ & $-50(3)$ & $\mathrm{O}(22)-\mathrm{C}(62)-\mathrm{C}(72)-\mathrm{I}(2)$ & $52(14)$ \\
\hline $\mathrm{O}(1)-\mathrm{C}(3)-\mathrm{C}(4)-\mathrm{O}(21)$ & $-92(4)$ & $\mathrm{C}(2)-\mathrm{C}(62)-\mathrm{C}(72)-\mathrm{I}(2)$ & $-45(8)$ \\
\hline$C(2)-C(3)-C(4)-O(21)$ & $23(4)$ & $\mathrm{O}(1)-\mathrm{C}(11)-\mathrm{C}(12)-\mathrm{C}(13)$ & $109.9(14)$ \\
\hline $\mathrm{O}(1)-\mathrm{C}(3)-\mathrm{C}(4)-\mathrm{O}(22)$ & $-87(14)$ & $\mathrm{O}(1)-\mathrm{C}(11)-\mathrm{C}(12)-\mathrm{C}(17)$ & $-67.2(16)$ \\
\hline$C(2)-C(3)-C(4)-O(22)$ & $27(14)$ & $C(17)-C(12)-C(13)-C(14)$ & $-2.4(19)$ \\
\hline $\mathrm{O}(1)-\mathrm{C}(3)-\mathrm{C}(4)-\mathrm{C}(5)$ & $148.5(11)$ & $C(11)-C(12)-C(13)-C(14)$ & $-179.6(12)$ \\
\hline$C(2)-C(3)-C(4)-C(5)$ & $-97.2(12)$ & $\mathrm{C}(12)-\mathrm{C}(13)-\mathrm{C}(14)-\mathrm{C}(15)$ & $0.2(19)$ \\
\hline $\mathrm{O}(21)-\mathrm{C}(4)-\mathrm{C}(5)-\mathrm{O}(3)$ & $167(2)$ & $C(13)-C(14)-C(15)-C(16)$ & $4(2)$ \\
\hline $\mathrm{O}(22)-\mathrm{C}(4)-\mathrm{C}(5)-\mathrm{O}(3)$ & $176(10)$ & $\mathrm{C}(13)-\mathrm{C}(14)-\mathrm{C}(15)-\mathrm{O}(4)$ & $-179.6(11)$ \\
\hline$C(3)-C(4)-C(5)-O(3)$ & $-73.2(14)$ & $C(14)-C(15)-C(16)-C(17)$ & $-5(2)$ \\
\hline $\mathrm{O}(22)-\mathrm{C}(4)-\mathrm{O}(21)-\mathrm{C}(61)$ & $-26(65)$ & $\mathrm{O}(4)-\mathrm{C}(15)-\mathrm{C}(16)-\mathrm{C}(17)$ & $178.2(11)$ \\
\hline$C(5)-C(4)-O(21)-C(61)$ & $117(4)$ & $\mathrm{C}(15)-\mathrm{C}(16)-\mathrm{C}(17)-\mathrm{C}(12)$ & $2(2)$ \\
\hline $\mathrm{C}(3)-\mathrm{C}(4)-\mathrm{O}(21)-\mathrm{C}(61)$ & $-7(5)$ & $C(13)-C(12)-C(17)-C(16)$ & $1(2)$ \\
\hline$C(4)-O(21)-C(61)-C(71)$ & $-129(4)$ & $C(11)-C(12)-C(17)-C(16)$ & $178.5(12)$ \\
\hline$C(4)-O(21)-C(61)-C(2)$ & $-12(5)$ & $\mathrm{O}(3)-\mathrm{C}(21)-\mathrm{C}(22)-\mathrm{C}(27)$ & $96.8(16)$ \\
\hline$C(3)-C(2)-C(61)-O(21)$ & $26(3)$ & $\mathrm{O}(3)-\mathrm{C}(21)-\mathrm{C}(22)-\mathrm{C}(23)$ & $-80.5(14)$ \\
\hline$C(1)-C(2)-C(61)-O(21)$ & $160(3)$ & $C(27)-C(22)-C(23)-C(24)$ & $4(2)$ \\
\hline$C(62)-C(2)-C(61)-O(21)$ & $111(9)$ & $\mathrm{C}(21)-\mathrm{C}(22)-\mathrm{C}(23)-\mathrm{C}(24)$ & $-178.4(14)$ \\
\hline$C(3)-C(2)-C(61)-C(71)$ & $145.6(12)$ & $\mathrm{C}(27)-\mathrm{C}(22)-\mathrm{C}(23)-\mathrm{Cl}(1)$ & $-178.5(10)$ \\
\hline$C(1)-C(2)-C(61)-C(71)$ & $-79.8(16)$ & $\mathrm{C}(21)-\mathrm{C}(22)-\mathrm{C}(23)-\mathrm{Cl}(1)$ & $-1.0(17)$ \\
\hline$C(62)-C(2)-C(61)-C(71)$ & $-129(9)$ & $\mathrm{C}(22)-\mathrm{C}(23)-\mathrm{C}(24)-\mathrm{C}(25)$ & $-4(3)$ \\
\hline $\mathrm{O}(21)-\mathrm{C}(61)-\mathrm{C}(71)-\mathrm{I}(1)$ & $-64(3)$ & $\mathrm{Cl}(1)-\mathrm{C}(23)-\mathrm{C}(24)-\mathrm{C}(25)$ & $178.4(16)$ \\
\hline $\mathrm{C}(2)-\mathrm{C}(61)-\mathrm{C}(71)-\mathrm{I}(1)$ & $178.4(8)$ & $C(23)-C(24)-C(25)-C(26)$ & $5(3)$ \\
\hline $\mathrm{O}(21)-\mathrm{C}(4)-\mathrm{O}(22)-\mathrm{C}(62)$ & $168(93)$ & $C(24)-C(25)-C(26)-C(27)$ & $-5(3)$ \\
\hline$C(5)-C(4)-O(22)-C(62)$ & $127(20)$ & $C(23)-C(22)-C(27)-C(26)$ & $-5(2)$ \\
\hline $\mathrm{C}(3)-\mathrm{C}(4)-\mathrm{O}(22)-\mathrm{C}(62)$ & $6(26)$ & $C(21)-C(22)-C(27)-C(26)$ & $177.8(14)$ \\
\hline $\mathrm{C}(4)-\mathrm{O}(22)-\mathrm{C}(62)-\mathrm{C}(72)$ & $-163(23)$ & $\mathrm{C}(23)-\mathrm{C}(22)-\mathrm{C}(27)-\mathrm{Cl}(2)$ & $178.0(9)$ \\
\hline $\mathrm{C}(4)-\mathrm{O}(22)-\mathrm{C}(62)-\mathrm{C}(2)$ & $-35(25)$ & $\mathrm{C}(21)-\mathrm{C}(22)-\mathrm{C}(27)-\mathrm{Cl}(2)$ & $1(2)$ \\
\hline $\mathrm{C}(3)-\mathrm{C}(2)-\mathrm{C}(62)-\mathrm{O}(22)$ & $48(12)$ & $C(25)-C(26)-C(27)-C(22)$ & $5(2)$ \\
\hline
\end{tabular}


$\mathrm{C}(25)-\mathrm{C}(26)-\mathrm{C}(27)-\mathrm{Cl}(2)$
$\mathrm{C}(2)-\mathrm{C}(3)-\mathrm{O}(1)-\mathrm{C}(11)$
$\mathrm{C}(4)-\mathrm{C}(3)-\mathrm{O}(1)-\mathrm{C}(11)$
$\mathrm{C}(12)-\mathrm{C}(11)-\mathrm{O}(1)-\mathrm{C}(3)$

$-177.3(13)$
$158.3(9)$
$-90.0(11)$
$-70.1(13)$

$\mathrm{C}(4)-\mathrm{C}(5)-\mathrm{O}(3)-\mathrm{C}(21)$

$175.5(10)$

$161.5(11)$

$\mathrm{C}(16)-\mathrm{C}(15)-\mathrm{O}(4)-\mathrm{C}(18)$

175.1(12)

$\mathrm{C}(14)-\mathrm{C}(15)-\mathrm{O}(4)-\mathrm{C}(18)$

$-2.1(19)$

Symmetry transformations used to generate equivalent atoms: 
Table B1. Crystal data and structure refinement for 61 .

Identification code

Empirical formula

Formula weight

Temperature

Wavelength

Crystal system

Space group

Unit cell dimensions

Volume

Z

Density (calculated)

Absorption coefficient

$\mathrm{F}(000)$

Crystal size

Theta range for data collection

Index ranges

Reflections collected

Independent reflections

Completeness to theta $=28.26^{\circ}$

Absorption correction

Max. and min. transmission

Refinement method

Data / restraints / parameters

Goodness-of-fit on $\mathrm{F}^{2}$

Final $R$ indices [I $>2 \operatorname{sigma}(\mathrm{I})]$

$\mathrm{R}$ indices (all data)

Absolute structure parameter

Largest diff. peak and hole
61

$\mathrm{C} 26 \mathrm{H} 34 \mathrm{O} 8$

474.53

153(2) K

$0.71073 \AA$

Orthorhombic

P2(1)2(1)2(1)

$\mathrm{a}=7.7070(4) \AA$

$\alpha=90^{\circ}$.

$\mathrm{b}=15.2117(7) \AA$

$\beta=90^{\circ}$.

$\mathrm{c}=20.8506(9) \AA$

$\gamma=90^{\circ}$.
4

$1.289 \mathrm{Mg} / \mathrm{m}^{3}$

$0.095 \mathrm{~mm}^{-1}$

1016

$0.27 \times 0.18 \times 0.16 \mathrm{~mm}^{3}$

1.66 to $28.26^{\circ}$.

$-9<=\mathrm{h}<=10,-19<=\mathrm{k}<=19,-26<=\mathrm{k}<=22$

19330

$5693[\mathrm{R}$ (int) $=0.0260]$

$96.1 \%$

Semi-empirical from equivalents

1.000 and 0.766

Full-matrix least-squares on $\mathrm{F}^{2}$

$5693 / 0 / 443$

1.072

$\mathrm{R} 1=0.0397, \mathrm{wR} 2=0.0911$

$\mathrm{R} 1=0.0446, \mathrm{wR} 2=0.0948$

$0.1(7)$

0.353 and -0.176 e. $\AA^{-3}$ 
Table B2. Atomic coordinates ( $\times 10^{4}$ ) and equivalent isotropic displacement parameters $\left(\AA^{2} \times 10^{3}\right)$ for 61 . U(eq) is defined as one third of the trace of the orthogonalized $\mathrm{Uij}^{\mathrm{ij}}$ tensor.

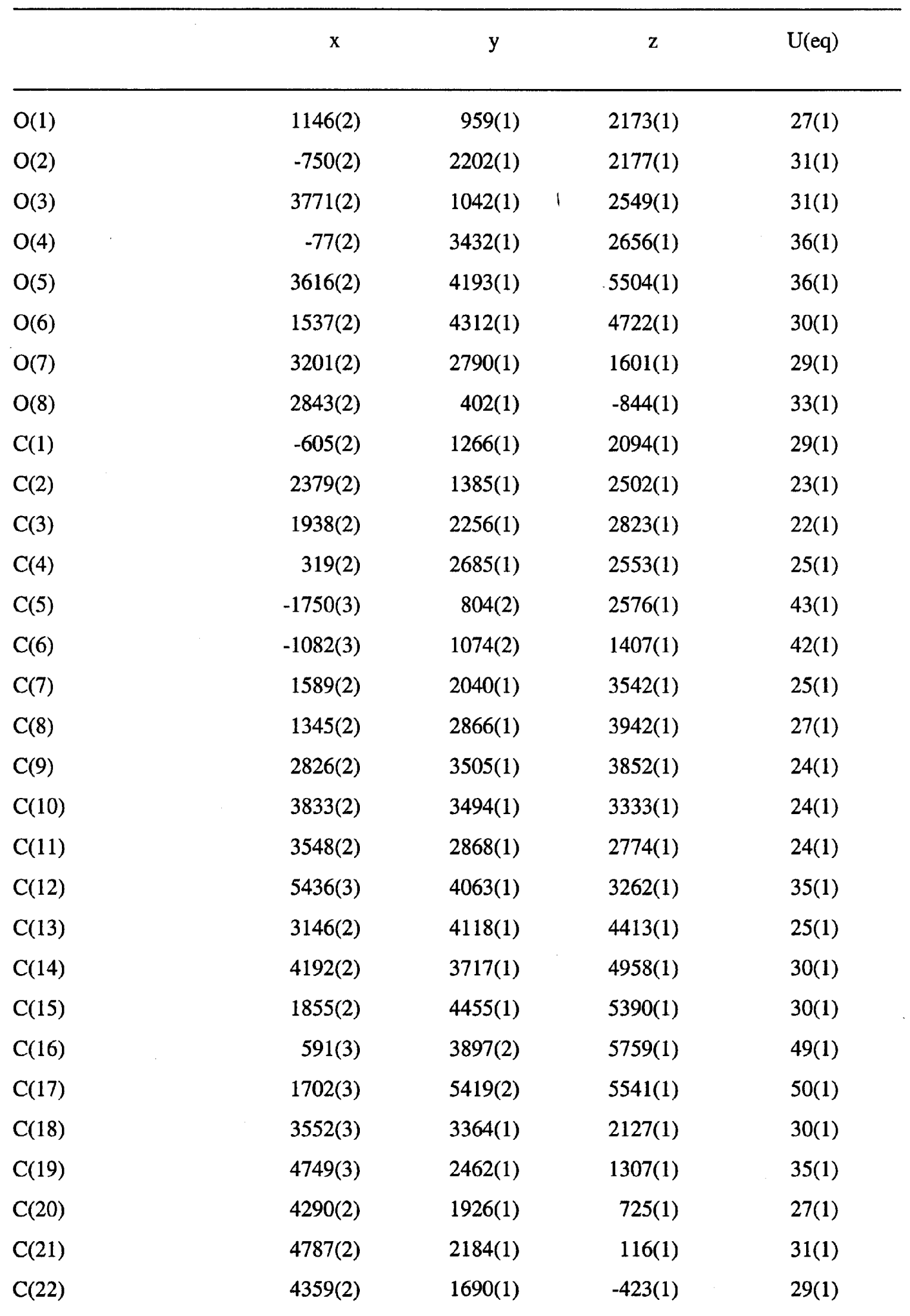




\begin{tabular}{lrrrr}
$\mathrm{C}(23)$ & $3386(2)$ & $928(1)$ & $-351(1)$ & $26(1)$ \\
$\mathrm{C}(24)$ & $2875(2)$ & $662(1)$ & $260(1)$ & $30(1)$ \\
$\mathrm{C}(25)$ & $3347(2)$ & $1148(1)$ & $789(1)$ & $30(1)$ \\
$\mathrm{C}(26)$ & $3437(3)$ & $623(1)$ & $-1469(1)$ & $35(1)$ \\
\hline
\end{tabular}


Table B3. Bond lengths $[\AA ̊]$ and angles $\left[{ }^{\circ}\right]$ for $\mathbf{6 1}$.

\begin{tabular}{|c|c|}
\hline $\mathrm{O}(1)-\mathrm{C}(2)$ & $1.340(2)$ \\
\hline $\mathrm{O}(1)-\mathrm{C}(1)$ & $1.438(2)$ \\
\hline $\mathrm{O}(2)-\mathrm{C}(4)$ & $1.354(2)$ \\
\hline $\mathrm{O}(2)-\mathrm{C}(1)$ & $1.438(2)$ \\
\hline $\mathrm{O}(3)-\mathrm{C}(2)$ & $1.197(2)$ \\
\hline $\mathrm{O}(4)-\mathrm{C}(4)$ & $1.196(2)$ \\
\hline $\mathrm{O}(5)-\mathrm{C}(14)$ & $1.420(2)$ \\
\hline $\mathrm{O}(5)-\mathrm{C}(15)$ & $1.435(2)$ \\
\hline $\mathrm{O}(6)-\mathrm{C}(13)$ & $1.428(2)$ \\
\hline $\mathrm{O}(6)-\mathrm{C}(15)$ & $1.431(2)$ \\
\hline $\mathrm{O}(7)-\mathrm{C}(18)$ & $1.428(2)$ \\
\hline $\mathrm{O}(7)-\mathrm{C}(19)$ & $1.431(2)$ \\
\hline $\mathrm{O}(8)-\mathrm{C}(23)$ & $1.368(2)$ \\
\hline $\mathrm{O}(8)-\mathrm{C}(26)$ & $1.422(2)$ \\
\hline$C(1)-C(6)$ & $1.508(3)$ \\
\hline$C(1)-C(5)$ & $1.510(3)$ \\
\hline $\mathrm{C}(2)-\mathrm{C}(3)$ & $1.523(2)$ \\
\hline$C(3)-C(4)$ & $1.517(2)$ \\
\hline$C(3)-C(11)$ & $1.554(2)$ \\
\hline$C(3)-C(7)$ & $1.558(2)$ \\
\hline$C(5)-H(5 A)$ & $1.00(3)$ \\
\hline $\mathrm{C}(5)-\mathrm{H}(5 \mathrm{~B})$ & $0.97(2)$ \\
\hline $\mathrm{C}(5)-\mathrm{H}(5 \mathrm{C})$ & $1.02(2)$ \\
\hline $\mathrm{C}(6)-\mathrm{H}(6 \mathrm{~A})$ & $0.94(2)$ \\
\hline $\mathrm{C}(6)-\mathrm{H}(6 \mathrm{~B})$ & $0.94(3)$ \\
\hline$C(6)-H(6 C)$ & $0.89(2)$ \\
\hline$C(7)-C(8)$ & $1.520(2)$ \\
\hline $\mathrm{C}(7)-\mathrm{H}(7 \mathrm{~A})$ & $0.99(2)$ \\
\hline $\mathrm{C}(7)-\mathrm{H}(7 \mathrm{~B})$ & $0.979(18)$ \\
\hline$C(8)-C(9)$ & $1.510(2)$ \\
\hline $\mathrm{C}(8)-\mathrm{H}(8 \mathrm{~A})$ & $0.97(2)$ \\
\hline $\mathrm{C}(8)-\mathrm{H}(8 \mathrm{~B})$ & $1.00(2)$ \\
\hline$C(9)-C(10)$ & $1.331(2)$ \\
\hline$C(9)-C(13)$ & $1.517(2)$ \\
\hline
\end{tabular}




\begin{tabular}{|c|c|}
\hline$C(10)-C(12)$ & $1.516(2)$ \\
\hline$C(10)-C(11)$ & $1.522(2)$ \\
\hline$C(11)-C(18)$ & $1.545(2)$ \\
\hline $\mathrm{C}(11)-\mathrm{H}(11)$ & $0.955(19)$ \\
\hline $\mathrm{C}(12)-\mathrm{H}(12 \mathrm{~A})$ & $0.93(3)$ \\
\hline $\mathrm{C}(12)-\mathrm{H}(12 \mathrm{~B})$ & $0.97(3)$ \\
\hline $\mathrm{C}(12)-\mathrm{H}(12 \mathrm{C})$ & $0.95(2)$ \\
\hline$C(13)-C(14)$ & $1.521(2)$ \\
\hline $\mathrm{C}(13)-\mathrm{H}(13)$ & $1.02(2)$ \\
\hline$C(14)-H(14 A)$ & $1.00(2)$ \\
\hline $\mathrm{C}(14)-\mathrm{H}(14 \mathrm{~B})$ & $1.01(2)$ \\
\hline$C(15)-C(17)$ & $1.504(3)$ \\
\hline$C(15)-C(16)$ & $1.504(3)$ \\
\hline $\mathrm{C}(16)-\mathrm{H}(16 \mathrm{~A})$ & $1.00(3)$ \\
\hline $\mathrm{C}(16)-\mathrm{H}(16 \mathrm{~B})$ & $0.96(3)$ \\
\hline$C(16)-H(16 C)$ & $0.88(2)$ \\
\hline $\mathrm{C}(17)-\mathrm{H}(17 \mathrm{~A})$ & $0.94(3)$ \\
\hline $\mathrm{C}(17)-\mathrm{H}(17 \mathrm{~B})$ & $0.97(3)$ \\
\hline $\mathrm{C}(17)-\mathrm{H}(17 \mathrm{C})$ & $1.05(4)$ \\
\hline $\mathrm{C}(18)-\mathrm{H}(18 \mathrm{~A})$ & $0.96(2)$ \\
\hline $\mathrm{C}(18)-\mathrm{H}(18 \mathrm{~B})$ & $1.03(2)$ \\
\hline$C(19)-C(20)$ & $1.504(2)$ \\
\hline $\mathrm{C}(19)-\mathrm{H}(19 \mathrm{~A})$ & $0.94(3)$ \\
\hline $\mathrm{C}(19)-\mathrm{H}(19 \mathrm{~B})$ & $0.91(2)$ \\
\hline$C(20)-C(21)$ & $1.384(2)$ \\
\hline$C(20)-C(25)$ & $1.395(3)$ \\
\hline$C(21)-C(22)$ & $1.391(2)$ \\
\hline $\mathrm{C}(21)-\mathrm{H}(21)$ & $0.95(2)$ \\
\hline$C(22)-C(23)$ & $1.389(2)$ \\
\hline $\mathrm{C}(22)-\mathrm{H}(22)$ & $0.948(19)$ \\
\hline$C(23)-C(24)$ & $1.393(2)$ \\
\hline$C(24)-C(25)$ & $1.378(3)$ \\
\hline $\mathrm{C}(24)-\mathrm{H}(24)$ & $0.95(2)$ \\
\hline $\mathrm{C}(25)-\mathrm{H}(25)$ & $0.91(2)$ \\
\hline $\mathrm{C}(26)-\mathrm{H}(26 \mathrm{~A})$ & $0.92(2)$ \\
\hline$C(26)-H(26 B)$ & $0.94(2)$ \\
\hline
\end{tabular}




\begin{tabular}{|c|c|}
\hline $\mathrm{C}(26)-\mathrm{H}(26 \mathrm{C})$ & $0.99(2)$ \\
\hline$C(2)-O(1)-C(1)$ & $124.61(13)$ \\
\hline $\mathrm{C}(4)-\mathrm{O}(2)-\mathrm{C}(1)$ & $124.03(13)$ \\
\hline$C(14)-O(5)-C(15)$ & $107.71(13)$ \\
\hline$C(13)-O(6)-C(15)$ & $108.73(13)$ \\
\hline$C(18)-O(7)-C(19)$ & $112.60(15)$ \\
\hline $\mathrm{C}(23)-\mathrm{O}(8)-\mathrm{C}(26)$ & $116.85(14)$ \\
\hline $\mathrm{O}(1)-\mathrm{C}(1)-\mathrm{O}(2)$ & $112.33(14)$ \\
\hline $\mathrm{O}(1)-\mathrm{C}(1)-\mathrm{C}(6)$ & $105.95(15)$ \\
\hline $\mathrm{O}(2)-\mathrm{C}(1)-\mathrm{C}(6)$ & $106.61(15)$ \\
\hline $\mathrm{O}(1)-\mathrm{C}(1)-\mathrm{C}(5)$ & $108.76(15)$ \\
\hline $\mathrm{O}(2)-\mathrm{C}(1)-\mathrm{C}(5)$ & $109.59(16)$ \\
\hline$C(6)-C(1)-C(5)$ & $113.61(18)$ \\
\hline $\mathrm{O}(3)-\mathrm{C}(2)-\mathrm{O}(1)$ & $117.83(14)$ \\
\hline $\mathrm{O}(3)-\mathrm{C}(2)-\mathrm{C}(3)$ & $122.95(15)$ \\
\hline $\mathrm{O}(1)-\mathrm{C}(2)-\mathrm{C}(3)$ & $119.17(14)$ \\
\hline$C(4)-C(3)-C(2)$ & $113.28(14)$ \\
\hline$C(4)-C(3)-C(11)$ & $112.03(12)$ \\
\hline$C(2)-C(3)-C(11)$ & $108.30(13)$ \\
\hline$C(4)-C(3)-C(7)$ & $107.81(13)$ \\
\hline$C(2)-C(3)-C(7)$ & $106.06(12)$ \\
\hline$C(11)-C(3)-C(7)$ & $109.14(13)$ \\
\hline $\mathrm{O}(4)-\mathrm{C}(4)-\mathrm{O}(2)$ & $117.72(16)$ \\
\hline$O(4)-C(4)-C(3)$ & $123.46(16)$ \\
\hline $\mathrm{O}(2)-\mathrm{C}(4)-\mathrm{C}(3)$ & $118.81(13)$ \\
\hline $\mathrm{C}(1)-\mathrm{C}(5)-\mathrm{H}(5 \mathrm{~A})$ & $111.2(14)$ \\
\hline $\mathrm{C}(1)-\mathrm{C}(5)-\mathrm{H}(5 \mathrm{~B})$ & $104.4(15)$ \\
\hline $\mathrm{H}(5 \mathrm{~A})-\mathrm{C}(5)-\mathrm{H}(5 \mathrm{~B})$ & $113(2)$ \\
\hline $\mathrm{C}(1)-\mathrm{C}(5)-\mathrm{H}(5 \mathrm{C})$ & $108.6(12)$ \\
\hline $\mathrm{H}(5 \mathrm{~A})-\mathrm{C}(5)-\mathrm{H}(5 \mathrm{C})$ & $108.1(19)$ \\
\hline $\mathrm{H}(5 \mathrm{~B})-\mathrm{C}(5)-\mathrm{H}(5 \mathrm{C})$ & $111.7(19)$ \\
\hline $\mathrm{C}(1)-\mathrm{C}(6)-\mathrm{H}(6 \mathrm{~A})$ & $107.2(15)$ \\
\hline$C(1)-C(6)-H(6 B)$ & $109.2(15)$ \\
\hline$H(6 A)-C(6)-H(6 B)$ & $112(2)$ \\
\hline $\mathrm{C}(1)-\mathrm{C}(6)-\mathrm{H}(6 \mathrm{C})$ & $108.0(15)$ \\
\hline
\end{tabular}




\begin{tabular}{|c|c|}
\hline $\mathrm{H}(6 \mathrm{~A})-\mathrm{C}(6)-\mathrm{H}(6 \mathrm{C})$ & $110(2)$ \\
\hline$H(6 B)-C(6)-H(6 C)$ & $109(2)$ \\
\hline$C(8)-C(7)-C(3)$ & $111.98(13)$ \\
\hline $\mathrm{C}(8)-\mathrm{C}(7)-\mathrm{H}(7 \mathrm{~A})$ & $107.9(11)$ \\
\hline $\mathrm{C}(3)-\mathrm{C}(7)-\mathrm{H}(7 \mathrm{~A})$ & $107.4(11)$ \\
\hline $\mathrm{C}(8)-\mathrm{C}(7)-\mathrm{H}(7 \mathrm{~B})$ & $111.4(10)$ \\
\hline $\mathrm{C}(3)-\mathrm{C}(7)-\mathrm{H}(7 \mathrm{~B})$ & $110.9(11)$ \\
\hline $\mathrm{H}(7 \mathrm{~A})-\mathrm{C}(7)-\mathrm{H}(7 \mathrm{~B})$ & $107.0(14)$ \\
\hline$C(9)-C(8)-C(7)$ & $111.75(14)$ \\
\hline $\mathrm{C}(9)-\mathrm{C}(8)-\mathrm{H}(8 \mathrm{~A})$ & $107.0(12)$ \\
\hline $\mathrm{C}(7)-\mathrm{C}(8)-\mathrm{H}(8 \mathrm{~A})$ & $108.5(11)$ \\
\hline $\mathrm{C}(9)-\mathrm{C}(8)-\mathrm{H}(8 \mathrm{~B})$ & $113.1(11)$ \\
\hline $\mathrm{C}(7)-\mathrm{C}(8)-\mathrm{H}(8 \mathrm{~B})$ & $109.9(11)$ \\
\hline $\mathrm{H}(8 \mathrm{~A})-\mathrm{C}(8)-\mathrm{H}(8 \mathrm{~B})$ & $106.3(17)$ \\
\hline$C(10)-C(9)-C(8)$ & $122.23(15)$ \\
\hline$C(10)-C(9)-C(13)$ & $122.65(15)$ \\
\hline$C(8)-C(9)-C(13)$ & $115.01(14)$ \\
\hline$C(9)-C(10)-C(12)$ & $123.23(15)$ \\
\hline$C(9)-C(10)-C(11)$ & $123.11(15)$ \\
\hline$C(12)-C(10)-C(11)$ & $113.55(14)$ \\
\hline$C(10)-C(11)-C(18)$ & $111.26(13)$ \\
\hline$C(10)-C(11)-C(3)$ & $116.06(13)$ \\
\hline$C(18)-C(11)-C(3)$ & $110.58(14)$ \\
\hline $\mathrm{C}(10)-\mathrm{C}(11)-\mathrm{H}(11)$ & $104.3(11)$ \\
\hline $\mathrm{C}(18)-\mathrm{C}(11)-\mathrm{H}(11)$ & $107.8(11)$ \\
\hline $\mathrm{C}(3)-\mathrm{C}(11)-\mathrm{H}(11)$ & $106.1(11)$ \\
\hline $\mathrm{C}(10)-\mathrm{C}(12)-\mathrm{H}(12 \mathrm{~A})$ & $109.4(15)$ \\
\hline $\mathrm{C}(10)-\mathrm{C}(12)-\mathrm{H}(12 \mathrm{~B})$ & $111.9(16)$ \\
\hline $\mathrm{H}(12 \mathrm{~A})-\mathrm{C}(12)-\mathrm{H}(12 \mathrm{~B})$ & $109(2)$ \\
\hline $\mathrm{C}(10)-\mathrm{C}(12)-\mathrm{H}(12 \mathrm{C})$ & $112.9(14)$ \\
\hline $\mathrm{H}(12 \mathrm{~A})-\mathrm{C}(12)-\mathrm{H}(12 \mathrm{C})$ & $110(2)$ \\
\hline $\mathrm{H}(12 \mathrm{~B})-\mathrm{C}(12)-\mathrm{H}(12 \mathrm{C})$ & $103.6(19)$ \\
\hline $\mathrm{O}(6)-\mathrm{C}(13)-\mathrm{C}(9)$ & $109.45(14)$ \\
\hline $\mathrm{O}(6)-\mathrm{C}(13)-\mathrm{C}(14)$ & $101.89(13)$ \\
\hline$C(9)-C(13)-C(14)$ & $114.54(14)$ \\
\hline $\mathrm{O}(6)-\mathrm{C}(13)-\mathrm{H}(13)$ & $109.5(11)$ \\
\hline
\end{tabular}




$\begin{array}{ll}\mathrm{C}(9)-\mathrm{C}(13)-\mathrm{H}(13) & 112.3(11) \\ \mathrm{C}(14)-\mathrm{C}(13)-\mathrm{H}(13) & 108.7(11) \\ \mathrm{O}(5)-\mathrm{C}(14)-\mathrm{C}(13) & 103.23(14) \\ \mathrm{O}(5)-\mathrm{C}(14)-\mathrm{H}(14 \mathrm{~A}) & 108.3(11) \\ \mathrm{C}(13)-\mathrm{C}(14)-\mathrm{H}(14 \mathrm{~A}) & 113.0(11) \\ \mathrm{O}(5)-\mathrm{C}(14)-\mathrm{H}(14 \mathrm{~B}) & 112.1(12) \\ \mathrm{C}(13)-\mathrm{C}(14)-\mathrm{H}(14 \mathrm{~B}) & 110.7(12) \\ \mathrm{H}(14 \mathrm{~A})-\mathrm{C}(14)-\mathrm{H}(14 \mathrm{~B}) & 109.3(16) \\ \mathrm{O}(6)-\mathrm{C}(15)-\mathrm{O}(5) & 106.35(13) \\ \mathrm{O}(6)-\mathrm{C}(15)-\mathrm{C}(17) & 109.83(17) \\ \mathrm{O}(5)-\mathrm{C}(15)-\mathrm{C}(17) & 108.13(16) \\ \mathrm{O}(6)-\mathrm{C}(15)-\mathrm{C}(16) & 107.48(16) \\ \mathrm{O}(5)-\mathrm{C}(15)-\mathrm{C}(16) & 111.76(17) \\ \mathrm{C}(17)-\mathrm{C}(15)-\mathrm{C}(16) & 113.1(2) \\ \mathrm{C}(15)-\mathrm{C}(16)-\mathrm{H}(16 \mathrm{~A}) & 107.8(16) \\ \mathrm{C}(15)-\mathrm{C}(16)-\mathrm{H}(16 \mathrm{~B}) & 111.8(16) \\ \mathrm{H}(16 \mathrm{~A})-\mathrm{C}(16)-\mathrm{H}(16 \mathrm{~B}) & 112(2) \\ \mathrm{C}(15)-\mathrm{C}(16)-\mathrm{H}(16 \mathrm{C}) & 105.1(14) \\ \mathrm{H}(16 \mathrm{~A})-\mathrm{C}(16)-\mathrm{H}(16 \mathrm{C}) & 108(2) \\ \mathrm{H}(16 \mathrm{~B})-\mathrm{C}(16)-\mathrm{H}(16 \mathrm{C}) & 112(2) \\ \mathrm{C}(15)-\mathrm{C}(17)-\mathrm{H}(17 \mathrm{~A}) & 107.4(18) \\ \mathrm{C}(15)-\mathrm{C}(17)-\mathrm{H}(17 \mathrm{~B}) & 111.7(15) \\ \mathrm{H}(17 \mathrm{~A})-\mathrm{C}(17)-\mathrm{H}(17 \mathrm{~B}) & 106(2) \\ \mathrm{C}(15)-\mathrm{C}(17)-\mathrm{H}(17 \mathrm{C}) & 111.6(18) \\ \mathrm{H}(17 \mathrm{~A})-\mathrm{C}(17)-\mathrm{H}(17 \mathrm{C}) & 108(3) \\ \mathrm{H}(17 \mathrm{~B})-\mathrm{C}(17)-\mathrm{H}(17 \mathrm{C}) & 112(2) \\ \mathrm{O}(7)-\mathrm{C}(18)-\mathrm{C}(11) & 111.80(13) \\ \mathrm{O}(7)-\mathrm{C}(18)-\mathrm{H}(18 A) & 110.7(14) \\ \mathrm{C}(11)-\mathrm{C}(18)-\mathrm{H}(18 \mathrm{~A}) & 109.6(14) \\ \mathrm{O}(7)-\mathrm{C}(18)-\mathrm{H}(18 \mathrm{~B}) & 107.6(13) \\ \mathrm{C}(11)-\mathrm{C}(18)-\mathrm{H}(18 \mathrm{~B}) & 110.0(13) \\ \mathrm{H}(18 \mathrm{~A})-\mathrm{C}(18)-\mathrm{H}(18 \mathrm{~B}) & 107.0(18) \\ \mathrm{O}(7)-\mathrm{C}(19)-\mathrm{C}(20) & 109.77(16) \\ \mathrm{O}(7)-\mathrm{C}(19)-\mathrm{H}(19 \mathrm{~B}) & 105.0(16) \\ & 114.0(15) \\ & 107.6(14) \\ & \end{array}$




$\begin{array}{ll}\mathrm{C}(20)-\mathrm{C}(19)-\mathrm{H}(19 \mathrm{~B}) & 107.8(14) \\ \mathrm{H}(19 \mathrm{~A})-\mathrm{C}(19)-\mathrm{H}(19 \mathrm{~B}) & 112(2) \\ \mathrm{C}(21)-\mathrm{C}(20)-\mathrm{C}(25) & 118.20(16) \\ \mathrm{C}(21)-\mathrm{C}(20)-\mathrm{C}(19) & 121.49(17) \\ \mathrm{C}(25)-\mathrm{C}(20)-\mathrm{C}(19) & 120.31(17) \\ \mathrm{C}(20)-\mathrm{C}(21)-\mathrm{C}(22) & 121.57(17) \\ \mathrm{C}(20)-\mathrm{C}(21)-\mathrm{H}(21) & 120.2(12) \\ \mathrm{C}(22)-\mathrm{C}(21)-\mathrm{H}(21) & 118.2(12) \\ \mathrm{C}(23)-\mathrm{C}(22)-\mathrm{C}(21) & 119.35(16) \\ \mathrm{C}(23)-\mathrm{C}(22)-\mathrm{H}(22) & 119.3(12) \\ \mathrm{C}(21)-\mathrm{C}(22)-\mathrm{H}(22) & 121.3(12) \\ \mathrm{O}(8)-\mathrm{C}(23)-\mathrm{C}(22) & 124.82(15) \\ \mathrm{O}(8)-\mathrm{C}(23)-\mathrm{C}(24) & 115.49(15) \\ \mathrm{C}(22)-\mathrm{C}(23)-\mathrm{C}(24) & 119.68(16) \\ \mathrm{C}(25)-\mathrm{C}(24)-\mathrm{C}(23) & 120.08(17) \\ \mathrm{C}(25)-\mathrm{C}(24)-\mathrm{H}(24) & 118.9(13) \\ \mathrm{C}(23)-\mathrm{C}(24)-\mathrm{H}(24) & 121.0(13) \\ \mathrm{C}(24)-\mathrm{C}(25)-\mathrm{C}(20) & 121.08(17) \\ \mathrm{C}(24)-\mathrm{C}(25)-\mathrm{H}(25) & 119.1(14) \\ \mathrm{C}(20)-\mathrm{C}(25)-\mathrm{H}(25) & 119.8(13) \\ \mathrm{O}(8)-\mathrm{C}(26)-\mathrm{H}(26 \mathrm{~A}) & 106.8(15) \\ \mathrm{O}(8)-\mathrm{C}(26)-\mathrm{H}(26 \mathrm{~B}) & 110.7(14) \\ \mathrm{H}(26 \mathrm{~A})-\mathrm{C}(26)-\mathrm{H}(26 \mathrm{~B}) & 109(2) \\ \mathrm{O}(8)-\mathrm{C}(26)-\mathrm{H}(26 \mathrm{C}) & 112.9(13) \\ \mathrm{H}(26 \mathrm{~A})-\mathrm{C}(26)-\mathrm{H}(26 \mathrm{C}) & 107.7(19) \\ \mathrm{H}(26 \mathrm{~B})-\mathrm{C}(26)-\mathrm{H}(26 \mathrm{C}) & 109.7(19) \\ & \end{array}$

Symmetry transformations used to generate equivalent atoms: 
Table B4. Anisotropic displacement parameters $\left(\AA^{2} \times 10^{3}\right)$ for 61. The anisotropic displacement factor exponent takes the form: $-2 \square^{2}\left[h^{2} a^{* 2} U^{11}+\ldots+2 h k a^{*} b^{*} U^{12}\right]$

\begin{tabular}{|c|c|c|c|c|c|c|}
\hline & $\mathrm{U}^{11}$ & $\mathrm{U}^{22}$ & $\mathrm{U}^{33}$ & $\mathbf{U}^{23}$ & $\mathrm{U}^{13}$ & $\mathrm{U}^{12}$ \\
\hline $\mathrm{O}(1)$ & $24(1)$ & $22(1)$ & $35(1)$ & $-5(1)$ & $-3(1)$ & $-1(1)$ \\
\hline $\mathrm{O}(2)$ & $31(1)$ & $26(1)$ & $36(1)$ & $-3(1)$ & $-10(1)$ & $6(1)$ \\
\hline$O(3)$ & $26(1)$ & $27(1)$ & $41(1)$ & $-4(1)$ & $-3(1)$ & $3(1)$ \\
\hline $\mathrm{O}(4)$ & $46(1)$ & $28(1)$ & $34(1)$ & $-4(1)$ & $-9(1)$ & $13(1)$ \\
\hline $\mathrm{O}(5)$ & $33(1)$ & $54(1)$ & $21(1)$ & $-6(1)$ & $-5(1)$ & $5(1)$ \\
\hline$O(6)$ & $30(1)$ & $42(1)$ & $20(1)$ & $-6(1)$ & $-2(1)$ & $7(1)$ \\
\hline $\mathrm{O}(7)$ & $36(1)$ & $30(1)$ & $22(1)$ & $-3(1)$ & $4(1)$ & $0(1)$ \\
\hline $\mathrm{O}(8)$ & $38(1)$ & $33(1)$ & $27(1)$ & $-6(1)$ & $3(1)$ & $-6(1)$ \\
\hline$C(1)$ & $27(1)$ & $26(1)$ & $35(1)$ & $-2(1)$ & $-4(1)$ & $2(1)$ \\
\hline$C(2)$ & $25(1)$ & $22(1)$ & $23(1)$ & $2(1)$ & $2(1)$ & $-2(1)$ \\
\hline$C(3)$ & $25(1)$ & $20(1)$ & $21(1)$ & $0(1)$ & $0(1)$ & $0(1)$ \\
\hline$C(4)$ & 31(1) & $26(1)$ & $19(1)$ & $1(1)$ & $0(1)$ & $3(1)$ \\
\hline$C(5)$ & $28(1)$ & $44(1)$ & $58(1)$ & $6(1)$ & $1(1)$ & $-6(1)$ \\
\hline$C(6)$ & $40(1)$ & $42(1)$ & $45(1)$ & $-14(1)$ & $-13(1)$ & $8(1)$ \\
\hline$C(7)$ & $28(1)$ & $26(1)$ & $22(1)$ & $5(1)$ & $0(1)$ & $-6(1)$ \\
\hline$C(8)$ & $28(1)$ & $34(1)$ & $20(1)$ & $0(1)$ & $4(1)$ & $-5(1)$ \\
\hline$C(9)$ & $28(1)$ & $23(1)$ & $20(1)$ & $1(1)$ & $-2(1)$ & $0(1)$ \\
\hline$C(10)$ & $28(1)$ & $23(1)$ & $23(1)$ & $-1(1)$ & $1(1)$ & $-3(1)$ \\
\hline$C(11)$ & $30(1)$ & $22(1)$ & $21(1)$ & $-2(1)$ & $5(1)$ & $-2(1)$ \\
\hline$C(12)$ & $39(1)$ & $35(1)$ & $31(1)$ & $-9(1)$ & $9(1)$ & $-13(1)$ \\
\hline$C(13)$ & $27(1)$ & $28(1)$ & $20(1)$ & $-2(1)$ & $1(1)$ & $1(1)$ \\
\hline$C(14)$ & $30(1)$ & $36(1)$ & $23(1)$ & $-1(1)$ & $-2(1)$ & $4(1)$ \\
\hline$C(15)$ & $28(1)$ & $42(1)$ & $19(1)$ & $-4(1)$ & $-1(1)$ & $-3(1)$ \\
\hline$C(16)$ & $46(1)$ & $66(2)$ & $37(1)$ & $10(1)$ & $2(1)$ & $-11(1)$ \\
\hline$C(17)$ & $39(1)$ & $54(1)$ & $58(2)$ & $-26(1)$ & $-9(1)$ & $0(1)$ \\
\hline$C(18)$ & $47(1)$ & $24(1)$ & $20(1)$ & $-1(1)$ & $7(1)$ & $-4(1)$ \\
\hline$C(19)$ & $32(1)$ & $44(1)$ & $29(1)$ & $-9(1)$ & $1(1)$ & $3(1)$ \\
\hline$C(20)$ & $26(1)$ & $32(1)$ & $24(1)$ & $-6(1)$ & $-1(1)$ & $5(1)$ \\
\hline$C(21)$ & $31(1)$ & $30(1)$ & $31(1)$ & $-3(1)$ & $5(1)$ & $-3(1)$ \\
\hline$C(22)$ & $33(1)$ & $31(1)$ & $24(1)$ & $-2(1)$ & $7(1)$ & $-1(1)$ \\
\hline$C(23)$ & $26(1)$ & $27(1)$ & $24(1)$ & $-4(1)$ & $1(1)$ & $4(1)$ \\
\hline
\end{tabular}




\begin{tabular}{lllllll}
$\mathrm{C}(24)$ & $35(1)$ & $26(1)$ & $28(1)$ & $1(1)$ & $4(1)$ & $-1(1)$ \\
$\mathrm{C}(25)$ & $38(1)$ & $33(1)$ & $20(1)$ & $3(1)$ & $4(1)$ & $7(1)$ \\
$\mathrm{C}(26)$ & $39(1)$ & $43(1)$ & $24(1)$ & $-10(1)$ & $2(1)$ & $0(1)$ \\
\hline
\end{tabular}


Table B5. Hydrogen coordinates $\left(\times 10^{4}\right)$ and isotropic displacement parameters $\left(\AA^{2} \mathrm{x}\right.$ $10^{3}$ ) for 61.

\begin{tabular}{|c|c|c|c|c|}
\hline & $\mathrm{x}$ & $\mathrm{y}$ & $\mathrm{z}$ & $\mathrm{U}(\mathrm{eq})$ \\
\hline $\mathrm{H}(5 \mathrm{~A})$ & $-1400(30)$ & $955(16)$ & $3027(12)$ & $52(7)$ \\
\hline $\mathrm{H}(5 \mathrm{~B})$ & $-1610(30)$ & $182(16)$ & $2479(12)$ & $50(7)$ \\
\hline $\mathrm{H}(5 \mathrm{C})$ & $-2990(30)$ & $1006(14)$ & $2509(10)$ & $40(6)$ \\
\hline$H(6 A)$ & $-330(30)$ & $1402(15)$ & $1146(12)$ & $43(6)$ \\
\hline$H(6 B)$ & $-2250(30)$ & $1224(16)$ & $1340(12)$ & $49(7)$ \\
\hline$H(6 C)$ & $-940(30)$ & $503(16)$ & $1339(11)$ & $41(6)$ \\
\hline $\mathrm{H}(7 \mathrm{~A})$ & $2630(30)$ & $1724(12)$ & $3708(9)$ & $25(5)$ \\
\hline $\mathrm{H}(7 \mathrm{~B})$ & $600(20)$ & $1640(11)$ & $3586(9)$ & $20(4)$ \\
\hline $\mathrm{H}(8 \mathrm{~A})$ & $1330(30)$ & $2701(12)$ & $4392(10)$ & $27(5)$ \\
\hline $\mathrm{H}(8 \mathrm{~B})$ & $190(30)$ & $3131(13)$ & $3851(9)$ & $28(5)$ \\
\hline $\mathrm{H}(11)$ & $4540(20)$ & $2491(12)$ & $2781(9)$ & $18(4)$ \\
\hline $\mathrm{H}(12 \mathrm{~A})$ & $6320(30)$ & $3736(16)$ & $3077(12)$ & $52(7)$ \\
\hline$H(12 B)$ & $5220(30)$ & $4574(18)$ & 2994(13) & $58(7)$ \\
\hline $\mathrm{H}(12 \mathrm{C})$ & $5810(30)$ & $4310(14)$ & $3656(11)$ & $42(6)$ \\
\hline $\mathrm{H}(13)$ & $3730(30)$ & $4689(13)$ & $4276(9)$ & $27(5)$ \\
\hline $\mathrm{H}(14 \mathrm{~A})$ & $5470(30)$ & $3810(12)$ & $4911(9)$ & $25(5)$ \\
\hline$H(14 B)$ & $3950(30)$ & $3065(13)$ & $4997(10)$ & $31(5)$ \\
\hline $\mathrm{H}(16 \mathrm{~A})$ & $740(40)$ & $4032(18)$ & $6225(14)$ & $65(8)$ \\
\hline $\mathrm{H}(16 \mathrm{~B})$ & $-580(40)$ & $3991(17)$ & $5621(12)$ & $55(7)$ \\
\hline$H(16 C)$ & $930(30)$ & $3353(14)$ & $5693(9)$ & $23(5)$ \\
\hline $\mathrm{H}(17 \mathrm{~A})$ & $2040(40)$ & $5496(19)$ & $5968(15)$ & $69(9)$ \\
\hline $\mathrm{H}(17 \mathrm{~B})$ & $510(40)$ & $5619(17)$ & $5514(12)$ & $53(7)$ \\
\hline $\mathrm{H}(17 \mathrm{C})$ & $2540(50)$ & $5800(20)$ & $5254(16)$ & $96(11)$ \\
\hline $\mathrm{H}(18 \mathrm{~A})$ & $4640(30)$ & $3655(15)$ & $2070(11)$ & $40(6)$ \\
\hline $\mathrm{H}(18 \mathrm{~B})$ & $2610(30)$ & $3842(15)$ & $2129(11)$ & $43(6)$ \\
\hline$H(19 A)$ & $5320(30)$ & $2140(16)$ & $1632(13)$ & $53(7)$ \\
\hline $\mathrm{H}(19 \mathrm{~B})$ & $5380(30)$ & $2934(14)$ & $1173(10)$ & $36(6)$ \\
\hline $\mathrm{H}(21)$ & $5400(30)$ & $2717(13)$ & $55(10)$ & $28(5)$ \\
\hline $\mathrm{H}(22)$ & $4710(30)$ & $1865(13)$ & $-840(9)$ & $26(5)$ \\
\hline $\mathrm{H}(24)$ & $2230(30)$ & $136(14)$ & $321(10)$ & $37(6)$ \\
\hline
\end{tabular}




\begin{tabular}{llrrr}
$\mathrm{H}(25)$ & $3000(30)$ & $968(14)$ & $1185(11)$ & $35(5)$ \\
$\mathrm{H}(26 \mathrm{~A})$ & $2960(30)$ & $219(15)$ & $-1747(11)$ & $48(7)$ \\
$\mathrm{H}(26 \mathrm{~B})$ & $4660(30)$ & $584(14)$ & $-1492(11)$ & $40(6)$ \\
$\mathrm{H}(26 \mathrm{C})$ & $3060(30)$ & $1215(15)$ & $-1608(11)$ & $43(6)$ \\
\hline
\end{tabular}


Table C1. Crystal data and structure refinement for $\mathbf{6 2}$.

Identification code

Empirical formula

Formula weight

Temperature

Wavelength

Crystal system

Space group

Unit cell dimensions

Volume

$\mathrm{Z}$

Density (calculated)

Absorption coefficient

$\mathrm{F}(000)$

Crystal size

Theta range for data collection

Index ranges

Reflections collected

Independent reflections

Completeness to theta $=28.21^{\circ}$

Absorption correction

Max. and min. transmission

Refinement method

Data / restraints / parameters

Goodness-of-fit on $\mathrm{F}^{2}$

Final $\mathrm{R}$ indices [ $\mathrm{I}>2 \operatorname{sigma}(\mathrm{I})]$

$\mathrm{R}$ indices (all data)

Absolute structure parameter

Largest diff. peak and hole
62

C26 H34 O8

474.53

153(2) K

$0.71073 \AA$

Monoclinic

P2(1)

$a=11.7306(15) \AA \quad \alpha=90^{\circ}$.

$\mathrm{b}=8.7908(11) \AA \quad \beta=100.087(2)^{\circ}$.

$c=11.8862(15) \AA \quad \gamma=90^{\circ}$.

$1206.8(3) \AA^{3}$

2

$1.306 \mathrm{Mg} / \mathrm{m}^{3}$

$0.096 \mathrm{~mm}^{-1}$

508

$0.32 \times 0.26 \times 0.16 \mathrm{~mm}^{3}$

1.74 to $28.21^{\circ}$.

$-15<=\mathrm{h}<=15,-11<=\mathrm{k}<=11,-15<=1<=15$

9352

$5345[\mathrm{R}$ (int $)=0.0185]$

$94.8 \%$

Semi-empirical from equivalents

1.000 and 0.772

Full-matrix least-squares on $\mathrm{F}^{2}$

$5345 / 1 / 443$

1.044

$\mathrm{R} 1=0.0375, \mathrm{wR} 2=0.0994$

$\mathrm{R} 1=0.0383, \mathrm{wR} 2=0.1006$

$0.1(6)$

0.355 and -0.188 e. $\AA^{-3}$ 
Table C2. Atomic coordinates ( $\times 10^{4}$ ) and equivalent isotropic displacement parameters $\left(\AA^{2} \times 10^{3}\right)$ for 62 . U(eq) is defined as one third of the trace of the orthogonalized Uij tensor.

\begin{tabular}{|c|c|c|c|c|}
\hline & $\mathrm{x}$ & $y$ & $\mathrm{z}$ & $\mathrm{U}(\mathrm{eq})$ \\
\hline $\mathrm{O}(1)$ & $3001(1)$ & $5349(1)$ & $9425(1)$ & $36(1)$ \\
\hline$O(2)$ & $3711(1)$ & $7892(1)$ & $9770(1)$ & $37(1)$ \\
\hline$O(3)$ & $1222(1)$ & $4885(1)$ & $8633(1)$ & $27(1)$ \\
\hline$O(4)$ & $2613(1)$ & $9873(1)$ & $9311(1)$ & $35(1)$ \\
\hline$O(5)$ & $-2112(1)$ & $5768(1)$ & $4248(1)$ & $26(1)$ \\
\hline$O(6)$ & $-1377(1)$ & $8038(1)$ & $4990(1)$ & $28(1)$ \\
\hline$O(7)$ & $1370(1)$ & $7248(1)$ & $10822(1)$ & $28(1)$ \\
\hline $\mathrm{O}(8)$ & $4427(1)$ & $7419(2)$ & $15804(1)$ & $35(1)$ \\
\hline$C(1)$ & 3993(1) & $6300(2)$ & 9741(2) & $29(1)$ \\
\hline$C(2)$ & $1963(1)$ & $5823(2)$ & $8884(1)$ & $21(1)$ \\
\hline$C(3)$ & $1772(1)$ & $7500(2)$ & $8602(1)$ & $20(1)$ \\
\hline$C(4)$ & $2710(1)$ & $8519(2)$ & $9258(1)$ & $24(1)$ \\
\hline$C(5)$ & $4798(2)$ & $6059(3)$ & $8894(2)$ & $41(1)$ \\
\hline$C(6)$ & $4509(2)$ & $5870(3)$ & $10955(2)$ & $40(1)$ \\
\hline$C(7)$ & $1820(1)$ & $7761(2)$ & $7315(1)$ & $23(1)$ \\
\hline$C(8)$ & $838(1)$ & $6964(2)$ & $6536(1)$ & $24(1)$ \\
\hline$C(9)$ & $-334(1)$ & $7271(2)$ & $6852(1)$ & $22(1)$ \\
\hline$C(10)$ & $-448(1)$ & $7774(2)$ & $7890(1)$ & $22(1)$ \\
\hline$C(11)$ & $579(1)$ & $8031(2)$ & $8853(1)$ & $21(1)$ \\
\hline$C(12)$ & $-1591(1)$ & $8211(2)$ & $8238(1)$ & $28(1)$ \\
\hline$C(13)$ & $-1358(1)$ & $6965(2)$ & $5921(1)$ & $23(1)$ \\
\hline$C(14)$ & $-1364(1)$ & $5439(2)$ & $5301(1)$ & $25(1)$ \\
\hline$C(15)$ & $-1796(1)$ & $7255(2)$ & $3932(1)$ & $26(1)$ \\
\hline$C(16)$ & $-2871(2)$ & $8039(2)$ & $3302(2)$ & $36(1)$ \\
\hline$C(17)$ & $-829(2)$ & $7170(2)$ & $3236(2)$ & $34(1)$ \\
\hline$C(18)$ & $337(1)$ & $7324(2)$ & $9981(1)$ & $25(1)$ \\
\hline$C(19)$ & $1566(2)$ & $8571(2)$ & $11533(1)$ & $31(1)$ \\
\hline$C(20)$ & $2413(1)$ & $8185(2)$ & $12600(1)$ & $27(1)$ \\
\hline$C(21)$ & $3327(1)$ & $9160(2)$ & $13002(1)$ & $29(1)$ \\
\hline$C(22)$ & $4031(1)$ & $8945(2)$ & $14062(1)$ & $30(1)$ \\
\hline
\end{tabular}




\begin{tabular}{lllll}
$\mathrm{C}(23)$ & $3820(1)$ & $7713(2)$ & $14733(1)$ & $27(1)$ \\
$\mathrm{C}(24)$ & $2933(1)$ & $6683(2)$ & $14324(1)$ & $28(1)$ \\
$\mathrm{C}(25)$ & $2245(1)$ & $6924(2)$ & $13266(1)$ & $28(1)$ \\
$\mathrm{C}(26)$ & $5242(2)$ & $8550(3)$ & $16287(2)$ & $50(1)$ \\
\hline
\end{tabular}


Table C3. Bond lengths $[\AA ̊]$ and angles $\left[{ }^{\circ}\right]$ for 62 .

\begin{tabular}{|c|c|}
\hline $\mathrm{O}(1)-\mathrm{C}(2)$ & $1.3401(18)$ \\
\hline $\mathrm{O}(1)-\mathrm{C}(1)$ & $1.429(2)$ \\
\hline $\mathrm{O}(2)-\mathrm{C}(4)$ & $1.3434(18)$ \\
\hline $\mathrm{O}(2)-\mathrm{C}(1)$ & $1.440(2)$ \\
\hline $\mathrm{O}(3)-\mathrm{C}(2)$ & $1.1977(18)$ \\
\hline $\mathrm{O}(4)-\mathrm{C}(4)$ & $1.199(2)$ \\
\hline $\mathrm{O}(5)-\mathrm{C}(14)$ & $1.4267(17)$ \\
\hline $\mathrm{O}(5)-\mathrm{C}(15)$ & $1.4276(18)$ \\
\hline $\mathrm{O}(6)-\mathrm{C}(15)$ & $1.4421(17)$ \\
\hline $\mathrm{O}(6)-\mathrm{C}(13)$ & $1.4507(17)$ \\
\hline $\mathrm{O}(7)-\mathrm{C}(18)$ & $1.4320(17)$ \\
\hline $\mathrm{O}(7)-\mathrm{C}(19)$ & $1.4321(19)$ \\
\hline $\mathrm{O}(8)-\mathrm{C}(23)$ & $1.3702(18)$ \\
\hline $\mathrm{O}(8)-\mathrm{C}(26)$ & $1.428(2)$ \\
\hline$C(1)-C(5)$ & $1.511(3)$ \\
\hline$C(1)-C(6)$ & $1.512(2)$ \\
\hline $\mathrm{C}(2)-\mathrm{C}(3)$ & $1.5198(19)$ \\
\hline$C(3)-C(4)$ & $1.5232(18)$ \\
\hline$C(3)-C(11)$ & $1.5533(19)$ \\
\hline$C(3)-C(7)$ & $1.5577(19)$ \\
\hline $\mathrm{C}(5)-\mathrm{H}(5 \mathrm{~A})$ & $0.98(3)$ \\
\hline$C(5)-H(5 B)$ & $0.92(3)$ \\
\hline $\mathrm{C}(5)-\mathrm{H}(5 \mathrm{C})$ & $0.96(3)$ \\
\hline $\mathrm{C}(6)-\mathrm{H}(6 \mathrm{~A})$ & $0.93(3)$ \\
\hline$C(6)-H(6 B)$ & $0.95(3)$ \\
\hline$C(6)-H(6 C)$ & $0.90(3)$ \\
\hline$C(7)-C(8)$ & $1.517(2)$ \\
\hline $\mathrm{C}(7)-\mathrm{H}(7 \mathrm{~A})$ & $0.94(2)$ \\
\hline $\mathrm{C}(7)-\mathrm{H}(7 \mathrm{~B})$ & $0.94(2)$ \\
\hline $\mathrm{C}(8)-\mathrm{C}(9)$ & $1.5118(19)$ \\
\hline $\mathrm{C}(8)-\mathrm{H}(8 \mathrm{~A})$ & $0.97(2)$ \\
\hline $\mathrm{C}(8)-\mathrm{H}(8 \mathrm{~B})$ & $0.96(2)$ \\
\hline$C(9)-C(10)$ & $1.340(2)$ \\
\hline$C(9)-C(13)$ & $1.5079(18)$ \\
\hline
\end{tabular}




\begin{tabular}{|c|c|}
\hline$C(10)-C(12)$ & $1.519(2)$ \\
\hline$C(10)-C(11)$ & $1.5263(18)$ \\
\hline$C(11)-C(18)$ & $1.5479(19)$ \\
\hline $\mathrm{C}(11)-\mathrm{H}(11)$ & $0.93(3)$ \\
\hline $\mathrm{C}(12)-\mathrm{H}(12 \mathrm{~A})$ & $0.99(3)$ \\
\hline $\mathrm{C}(12)-\mathrm{H}(12 \mathrm{~B})$ & $0.97(3)$ \\
\hline $\mathrm{C}(12)-\mathrm{H}(12 \mathrm{C})$ & $0.98(3)$ \\
\hline$C(13)-C(14)$ & $1.530(2)$ \\
\hline $\mathrm{C}(13)-\mathrm{H}(13)$ & $0.982(19)$ \\
\hline $\mathrm{C}(14)-\mathrm{H}(14 \mathrm{~A})$ & $0.93(2)$ \\
\hline $\mathrm{C}(14)-\mathrm{H}(14 \mathrm{~B})$ & $0.956(17)$ \\
\hline$C(15)-C(16)$ & $1.515(2)$ \\
\hline$C(15)-C(17)$ & $1.518(2)$ \\
\hline$C(16)-H(16 A)$ & $0.92(3)$ \\
\hline$C(16)-H(16 B)$ & $0.95(3)$ \\
\hline $\mathrm{C}(16)-\mathrm{H}(16 \mathrm{C})$ & $0.88(2)$ \\
\hline $\mathrm{C}(17)-\mathrm{H}(17 \mathrm{~A})$ & $0.99(3)$ \\
\hline $\mathrm{C}(17)-\mathrm{H}(17 \mathrm{~B})$ & $1.04(3)$ \\
\hline $\mathrm{C}(17)-\mathrm{H}(17 \mathrm{C})$ & $0.99(3)$ \\
\hline $\mathrm{C}(18)-\mathrm{H}(18 \mathrm{~A})$ & $1.00(2)$ \\
\hline $\mathrm{C}(18)-\mathrm{H}(18 \mathrm{~B})$ & $0.94(2)$ \\
\hline$C(19)-C(20)$ & $1.507(2)$ \\
\hline$C(19)-H(19 A)$ & $0.98(3)$ \\
\hline $\mathrm{C}(19)-\mathrm{H}(19 \mathrm{~B})$ & $0.97(2)$ \\
\hline$C(20)-C(21)$ & $1.390(2)$ \\
\hline$C(20)-C(25)$ & $1.396(2)$ \\
\hline$C(21)-C(22)$ & $1.393(2)$ \\
\hline $\mathrm{C}(21)-\mathrm{H}(21)$ & $0.94(3)$ \\
\hline$C(22)-C(23)$ & $1.393(2)$ \\
\hline $\mathrm{C}(22)-\mathrm{H}(22)$ & $0.96(2)$ \\
\hline$C(23)-C(24)$ & $1.401(2)$ \\
\hline$C(24)-C(25)$ & $1.386(2)$ \\
\hline $\mathrm{C}(24)-\mathrm{H}(24)$ & $0.91(2)$ \\
\hline $\mathrm{C}(25)-\mathrm{H}(25)$ & $0.90(2)$ \\
\hline $\mathrm{C}(26)-\mathrm{H}(26 \mathrm{~A})$ & $1.00(4)$ \\
\hline$C(26)-H(26 B)$ & $0.95(3)$ \\
\hline
\end{tabular}




\begin{tabular}{|c|c|}
\hline$C(26)-H(26 C)$ & $1.02(3)$ \\
\hline$C(2)-O(1)-C(1)$ & $125.01(12)$ \\
\hline $\mathrm{C}(4)-\mathrm{O}(2)-\mathrm{C}(1)$ & $125.04(12)$ \\
\hline$C(14)-O(5)-C(15)$ & $105.54(11)$ \\
\hline$C(15)-O(6)-C(13)$ & $108.18(11)$ \\
\hline$C(18)-O(7)-C(19)$ & $113.75(12)$ \\
\hline$C(23)-O(8)-C(26)$ & $116.35(14)$ \\
\hline $\mathrm{O}(1)-\mathrm{C}(1)-\mathrm{O}(2)$ & $113.27(12)$ \\
\hline $\mathrm{O}(1)-\mathrm{C}(1)-\mathrm{C}(5)$ & $108.55(15)$ \\
\hline $\mathrm{O}(2)-\mathrm{C}(1)-\mathrm{C}(5)$ & $108.96(15)$ \\
\hline $\mathrm{O}(1)-\mathrm{C}(1)-\mathrm{C}(6)$ & $106.00(15)$ \\
\hline $\mathrm{O}(2)-\mathrm{C}(1)-\mathrm{C}(6)$ & $105.98(15)$ \\
\hline$C(5)-C(1)-C(6)$ & $114.16(15)$ \\
\hline $\mathrm{O}(3)-\mathrm{C}(2)-\mathrm{O}(1)$ & $117.66(13)$ \\
\hline $\mathrm{O}(3)-\mathrm{C}(2)-\mathrm{C}(3)$ & $122.69(12)$ \\
\hline $\mathrm{O}(1)-\mathrm{C}(2)-\mathrm{C}(3)$ & $119.64(12)$ \\
\hline$C(2)-C(3)-C(4)$ & $113.09(11)$ \\
\hline$C(2)-C(3)-C(11)$ & $110.66(11)$ \\
\hline$C(4)-C(3)-C(11)$ & $108.63(11)$ \\
\hline$C(2)-C(3)-C(7)$ & $109.26(11)$ \\
\hline$C(4)-C(3)-C(7)$ & $105.60(11)$ \\
\hline$C(11)-C(3)-C(7)$ & $109.45(11)$ \\
\hline $\mathrm{O}(4)-\mathrm{C}(4)-\mathrm{O}(2)$ & $117.85(13)$ \\
\hline $\mathrm{O}(4)-\mathrm{C}(4)-\mathrm{C}(3)$ & $122.98(14)$ \\
\hline $\mathrm{O}(2)-\mathrm{C}(4)-\mathrm{C}(3)$ & $119.13(13)$ \\
\hline $\mathrm{C}(1)-\mathrm{C}(5)-\mathrm{H}(5 \mathrm{~A})$ & $110.4(15)$ \\
\hline $\mathrm{C}(1)-\mathrm{C}(5)-\mathrm{H}(5 \mathrm{~B})$ & $108.8(15)$ \\
\hline$H(5 A)-C(5)-H(5 B)$ & $113(2)$ \\
\hline$C(1)-C(5)-H(5 C)$ & $109.1(16)$ \\
\hline $\mathrm{H}(5 \mathrm{~A})-\mathrm{C}(5)-\mathrm{H}(5 \mathrm{C})$ & $107(2)$ \\
\hline $\mathrm{H}(5 \mathrm{~B})-\mathrm{C}(5)-\mathrm{H}(5 \mathrm{C})$ & $108(2)$ \\
\hline$C(1)-C(6)-H(6 A)$ & $109.6(15)$ \\
\hline$C(1)-C(6)-H(6 B)$ & $106.5(19)$ \\
\hline $\mathrm{H}(6 \mathrm{~A})-\mathrm{C}(6)-\mathrm{H}(6 \mathrm{~B})$ & $117(3)$ \\
\hline$C(1)-C(6)-H(6 C)$ & $106.0(14)$ \\
\hline
\end{tabular}




\begin{tabular}{|c|c|}
\hline$H(6 A)-C(6)-H(6 C)$ & $108(2)$ \\
\hline$H(6 B)-C(6)-H(6 C)$ & $109(3)$ \\
\hline$C(8)-C(7)-C(3)$ & $112.21(12)$ \\
\hline $\mathrm{C}(8)-\mathrm{C}(7)-\mathrm{H}(7 \mathrm{~A})$ & $109.4(13)$ \\
\hline $\mathrm{C}(3)-\mathrm{C}(7)-\mathrm{H}(7 \mathrm{~A})$ & $104.5(13)$ \\
\hline $\mathrm{C}(8)-\mathrm{C}(7)-\mathrm{H}(7 \mathrm{~B})$ & $110.8(12)$ \\
\hline $\mathrm{C}(3)-\mathrm{C}(7)-\mathrm{H}(7 \mathrm{~B})$ & $112.8(12)$ \\
\hline $\mathrm{H}(7 \mathrm{~A})-\mathrm{C}(7)-\mathrm{H}(7 \mathrm{~B})$ & $106.7(18)$ \\
\hline$C(9)-C(8)-C(7)$ & $113.07(12)$ \\
\hline$C(9)-C(8)-H(8 A)$ & $110.5(13)$ \\
\hline$C(7)-C(8)-H(8 A)$ & $108.9(14)$ \\
\hline $\mathrm{C}(9)-\mathrm{C}(8)-\mathrm{H}(8 \mathrm{~B})$ & $108.3(13)$ \\
\hline $\mathrm{C}(7)-\mathrm{C}(8)-\mathrm{H}(8 \mathrm{~B})$ & $112.1(13)$ \\
\hline $\mathrm{H}(8 \mathrm{~A})-\mathrm{C}(8)-\mathrm{H}(8 \mathrm{~B})$ & $104(2)$ \\
\hline$C(10)-C(9)-C(13)$ & $122.64(13)$ \\
\hline$C(10)-C(9)-C(8)$ & $122.01(12)$ \\
\hline$C(13)-C(9)-C(8)$ & $115.35(12)$ \\
\hline$C(9)-C(10)-C(12)$ & $124.72(12)$ \\
\hline$C(9)-C(10)-C(11)$ & $123.12(12)$ \\
\hline$C(12)-C(10)-C(11)$ & $112.12(12)$ \\
\hline$C(10)-C(11)-C(18)$ & $110.45(11)$ \\
\hline$C(10)-C(11)-C(3)$ & $115.53(11)$ \\
\hline $\mathrm{C}(18)-\mathrm{C}(11)-\mathrm{C}(3)$ & $110.71(11)$ \\
\hline $\mathrm{C}(10)-\mathrm{C}(11)-\mathrm{H}(11)$ & $106.2(12)$ \\
\hline $\mathrm{C}(18)-\mathrm{C}(11)-\mathrm{H}(11)$ & $105.6(13)$ \\
\hline $\mathrm{C}(3)-\mathrm{C}(11)-\mathrm{H}(11)$ & $107.8(13)$ \\
\hline $\mathrm{C}(10)-\mathrm{C}(12)-\mathrm{H}(12 \mathrm{~A})$ & $110.5(14)$ \\
\hline$C(10)-C(12)-H(12 B)$ & $115.3(15)$ \\
\hline $\mathrm{H}(12 \mathrm{~A})-\mathrm{C}(12)-\mathrm{H}(12 \mathrm{~B})$ & $108(2)$ \\
\hline$C(10)-C(12)-H(12 C)$ & $113.2(15)$ \\
\hline $\mathrm{H}(12 \mathrm{~A})-\mathrm{C}(12)-\mathrm{H}(12 \mathrm{C})$ & $103(2)$ \\
\hline $\mathrm{H}(12 \mathrm{~B})-\mathrm{C}(12)-\mathrm{H}(12 \mathrm{C})$ & $106(2)$ \\
\hline $\mathrm{O}(6)-\mathrm{C}(13)-\mathrm{C}(9)$ & $110.37(11)$ \\
\hline $\mathrm{O}(6)-\mathrm{C}(13)-\mathrm{C}(14)$ & $101.83(11)$ \\
\hline$C(9)-C(13)-C(14)$ & $116.43(12)$ \\
\hline $\mathrm{O}(6)-\mathrm{C}(13)-\mathrm{H}(13)$ & $109.5(12)$ \\
\hline
\end{tabular}




\begin{tabular}{ll}
$\mathrm{C}(9)-\mathrm{C}(13)-\mathrm{H}(13)$ & $108.0(11)$ \\
$\mathrm{C}(14)-\mathrm{C}(13)-\mathrm{H}(13)$ & $110.5(13)$ \\
$\mathrm{O}(5)-\mathrm{C}(14)-\mathrm{C}(13)$ & $101.23(12)$ \\
$\mathrm{O}(5)-\mathrm{C}(14)-\mathrm{H}(14 \mathrm{~A})$ & $107.6(12)$ \\
$\mathrm{C}(13)-\mathrm{C}(14)-\mathrm{H}(14 \mathrm{~A})$ & $111.6(13)$ \\
$\mathrm{O}(5)-\mathrm{C}(14)-\mathrm{H}(14 \mathrm{~B})$ & $109.1(10)$ \\
$\mathrm{C}(13)-\mathrm{C}(14)-\mathrm{H}(14 \mathrm{~B})$ & $110.9(11)$ \\
$\mathrm{H}(14 \mathrm{~A})-\mathrm{C}(14)-\mathrm{H}(14 \mathrm{~B})$ & $115.4(17)$ \\
$\mathrm{O}(5)-\mathrm{C}(15)-\mathrm{O}(6)$ & $105.80(11)$ \\
$\mathrm{O}(5)-\mathrm{C}(15)-\mathrm{C}(16)$ & $108.32(13)$ \\
$\mathrm{O}(6)-\mathrm{C}(15)-\mathrm{C}(16)$ & $109.91(13)$ \\
$\mathrm{O}(5)-\mathrm{C}(15)-\mathrm{C}(17)$ & $110.61(13)$ \\
$\mathrm{O}(6)-\mathrm{C}(15)-\mathrm{C}(17)$ & $109.02(13)$ \\
$\mathrm{C}(16)-\mathrm{C}(15)-\mathrm{C}(17)$ & $112.93(14)$ \\
$\mathrm{C}(15)-\mathrm{C}(16)-\mathrm{H}(16 \mathrm{~A})$ & $110.9(15)$ \\
$\mathrm{C}(15)-\mathrm{C}(16)-\mathrm{H}(16 \mathrm{~B})$ & $114.4(18)$ \\
$\mathrm{H}(16 \mathrm{~A})-\mathrm{C}(16)-\mathrm{H}(16 \mathrm{~B})$ & $102(2)$ \\
$\mathrm{C}(15)-\mathrm{C}(16)-\mathrm{H}(16 \mathrm{C})$ & $110.2(14)$ \\
$\mathrm{H}(16 \mathrm{~A})-\mathrm{C}(16)-\mathrm{H}(16 \mathrm{C})$ & $111(2)$ \\
$\mathrm{H}(16 \mathrm{~B})-\mathrm{C}(16)-\mathrm{H}(16 \mathrm{C})$ & $108(2)$ \\
$\mathrm{C}(15)-\mathrm{C}(17)-\mathrm{H}(17 \mathrm{~A})$ & $111.0(15)$ \\
$\mathrm{C}(15)-\mathrm{C}(17)-\mathrm{H}(17 \mathrm{~B})$ & $110.9(14)$ \\
$\mathrm{H}(17 \mathrm{~A})-\mathrm{C}(17)-\mathrm{H}(17 \mathrm{~B})$ & $111(2)$ \\
$\mathrm{C}(15)-\mathrm{C}(17)-\mathrm{H}(17 \mathrm{C})$ & $110.3(14)$ \\
$\mathrm{H}(17 \mathrm{~A})-\mathrm{C}(17)-\mathrm{H}(17 \mathrm{C})$ & $108(2)$ \\
$\mathrm{H}(17 \mathrm{~B})-\mathrm{C}(17)-\mathrm{H}(17 \mathrm{C})$ & $105(2)$ \\
$\mathrm{O}(7)-\mathrm{C}(18)-\mathrm{C}(11)$ & $111.25(12)$ \\
$\mathrm{O}(7)-\mathrm{C}(18)-\mathrm{H}(18 \mathrm{~A})$ & $105.8(11)$ \\
$\mathrm{C}(11)-\mathrm{C}(18)-\mathrm{H}(18 \mathrm{~A})$ & $108.4(11)$ \\
$\mathrm{O}(7)-\mathrm{C}(18)-\mathrm{H}(18 \mathrm{~B})$ & $111.5(11)$ \\
$\mathrm{C}(11)-\mathrm{C}(18)-\mathrm{H}(18 \mathrm{~B})$ & $113.4(12)$ \\
$\mathrm{H}(18 \mathrm{~A})-\mathrm{C}(18)-\mathrm{H}(18 \mathrm{~B})$ & $106.1(17)$ \\
$\mathrm{O})-\mathrm{C}(19)-\mathrm{C}(20)$ & $109.13(13)$ \\
& $111.3(16)$ \\
& $108.5(15)$ \\
\hline & $108.5(12)$
\end{tabular}




$\begin{array}{ll}\mathrm{C}(20)-\mathrm{C}(19)-\mathrm{H}(19 \mathrm{~B}) & 109.0(11) \\ \mathrm{H}(19 \mathrm{~A})-\mathrm{C}(19)-\mathrm{H}(19 \mathrm{~B}) & 110(2) \\ \mathrm{C}(21)-\mathrm{C}(20)-\mathrm{C}(25) & 118.16(14) \\ \mathrm{C}(21)-\mathrm{C}(20)-\mathrm{C}(19) & 120.36(15) \\ \mathrm{C}(25)-\mathrm{C}(20)-\mathrm{C}(19) & 121.21(15) \\ \mathrm{C}(20)-\mathrm{C}(21)-\mathrm{C}(22) & 121.76(15) \\ \mathrm{C}(20)-\mathrm{C}(21)-\mathrm{H}(21) & 119.2(15) \\ \mathrm{C}(22)-\mathrm{C}(21)-\mathrm{H}(21) & 119.1(15) \\ \mathrm{C}(23)-\mathrm{C}(22)-\mathrm{C}(21) & 119.16(15) \\ \mathrm{C}(23)-\mathrm{C}(22)-\mathrm{H}(22) & 120.8(13) \\ \mathrm{C}(21)-\mathrm{C}(22)-\mathrm{H}(22) & 120.0(13) \\ \mathrm{O}(8)-\mathrm{C}(23)-\mathrm{C}(22) & 124.33(14) \\ \mathrm{O}(8)-\mathrm{C}(23)-\mathrm{C}(24) & 115.72(14) \\ \mathrm{C}(22)-\mathrm{C}(23)-\mathrm{C}(24) & 119.96(14) \\ \mathrm{C}(25)-\mathrm{C}(24)-\mathrm{C}(23) & 119.69(15) \\ \mathrm{C}(25)-\mathrm{C}(24)-\mathrm{H}(24) & 119.6(14) \\ \mathrm{C}(23)-\mathrm{C}(24)-\mathrm{H}(24) & 120.7(14) \\ \mathrm{C}(24)-\mathrm{C}(25)-\mathrm{C}(20) & 121.18(15) \\ \mathrm{C}(24)-\mathrm{C}(25)-\mathrm{H}(25) & 119.3(14) \\ \mathrm{C}(20)-\mathrm{C}(25)-\mathrm{H}(25) & 119.4(14) \\ \mathrm{O}(8)-\mathrm{C}(26)-\mathrm{H}(26 \mathrm{~A}) & 108(2) \\ \mathrm{O}(8)-\mathrm{C}(26)-\mathrm{H}(26 \mathrm{~B}) & 106.3(17) \\ \mathrm{H}(26 \mathrm{~A})-\mathrm{C}(26)-\mathrm{H}(26 \mathrm{~B}) & 106(2) \\ \mathrm{O}(8)-\mathrm{C}(26)-\mathrm{H}(26 \mathrm{C}) & 110.1(17) \\ \mathrm{H}(26 \mathrm{~A})-\mathrm{C}(26)-\mathrm{H}(26 \mathrm{C}) & 115(3) \\ \mathrm{H}(26 \mathrm{~B})-\mathrm{C}(26)-\mathrm{H}(26 \mathrm{C}) & 111(2) \\ & \end{array}$

Symmetry transformations used to generate equivalent atoms: 
Table C4. Anisotropic displacement parameters $\left(\AA^{2} \times 10^{3}\right)$ for 62 . The anisotropic displacement factor exponent takes the form $-2 \pi^{2}\left[h^{2} a^{* 2} U^{11}+\ldots+2 h k a^{*} b^{*} U^{12}\right]$

\begin{tabular}{|c|c|c|c|c|c|c|}
\hline & $\mathrm{U}^{11}$ & $\mathrm{U}^{22}$ & $\mathbf{U}^{33}$ & $\mathrm{U}^{23}$ & $U^{13}$ & $\mathrm{U}^{12}$ \\
\hline $\mathrm{O}(1)$ & $30(1)$ & $19(1)$ & $55(1)$ & $0(1)$ & $-5(1)$ & $5(1)$ \\
\hline $\mathrm{O}(2)$ & $25(1)$ & $24(1)$ & $56(1)$ & $-6(1)$ & $-8(1)$ & $-1(1)$ \\
\hline$O(3)$ & $31(1)$ & $18(1)$ & $31(1)$ & $0(1)$ & $5(1)$ & $-3(1)$ \\
\hline $\mathrm{O}(4)$ & $32(1)$ & $20(1)$ & $49(1)$ & $-1(1)$ & $-2(1)$ & $-4(1)$ \\
\hline $\mathrm{O}(5)$ & $32(1)$ & $23(1)$ & $23(1)$ & $-2(1)$ & $1(1)$ & $-7(1)$ \\
\hline$O(6)$ & $39(1)$ & $18(1)$ & $22(1)$ & $1(1)$ & $-5(1)$ & $-2(1)$ \\
\hline $\mathrm{O}(7)$ & $31(1)$ & $30(1)$ & $21(1)$ & $-4(1)$ & $-1(1)$ & $9(1)$ \\
\hline$O(8)$ & $35(1)$ & $38(1)$ & $29(1)$ & $4(1)$ & $-6(1)$ & $-2(1)$ \\
\hline$C(1)$ & $23(1)$ & $26(1)$ & $37(1)$ & $-1(1)$ & $0(1)$ & $5(1)$ \\
\hline$C(2)$ & $24(1)$ & $20(1)$ & $19(1)$ & $0(1)$ & $4(1)$ & $1(1)$ \\
\hline$C(3)$ & $20(1)$ & $16(1)$ & $22(1)$ & $0(1)$ & $0(1)$ & $-1(1)$ \\
\hline$C(4)$ & $22(1)$ & $22(1)$ & $28(1)$ & $0(1)$ & $1(1)$ & $-2(1)$ \\
\hline$C(5)$ & $39(1)$ & $45(1)$ & $39(1)$ & $5(1)$ & $8(1)$ & $7(1)$ \\
\hline$C(6)$ & $42(1)$ & $42(1)$ & $35(1)$ & $0(1)$ & $1(1)$ & $8(1)$ \\
\hline$C(7)$ & $23(1)$ & $24(1)$ & $23(1)$ & $4(1)$ & $5(1)$ & $0(1)$ \\
\hline $\mathrm{C}(8)$ & $26(1)$ & $26(1)$ & $20(1)$ & $0(1)$ & $4(1)$ & $1(1)$ \\
\hline $\mathrm{C}(9)$ & $23(1)$ & $17(1)$ & $23(1)$ & $1(1)$ & $0(1)$ & $1(1)$ \\
\hline$C(10)$ & $21(1)$ & $17(1)$ & $25(1)$ & $1(1)$ & $1(1)$ & $1(1)$ \\
\hline$C(11)$ & $22(1)$ & $17(1)$ & $22(1)$ & $-2(1)$ & $2(1)$ & $1(1)$ \\
\hline $\mathrm{C}(12)$ & $24(1)$ & $31(1)$ & $28(1)$ & $-6(1)$ & $1(1)$ & $4(1)$ \\
\hline$C(13)$ & $26(1)$ & $22(1)$ & $21(1)$ & $1(1)$ & $3(1)$ & $0(1)$ \\
\hline$C(14)$ & $32(1)$ & $20(1)$ & $23(1)$ & $1(1)$ & $4(1)$ & $-4(1)$ \\
\hline$C(15)$ & $31(1)$ & $21(1)$ & $22(1)$ & $0(1)$ & $-1(1)$ & $-1(1)$ \\
\hline$C(16)$ & $34(1)$ & $39(1)$ & $32(1)$ & $1(1)$ & $-7(1)$ & $1(1)$ \\
\hline$C(17)$ & $42(1)$ & $29(1)$ & $34(1)$ & $5(1)$ & $10(1)$ & $-2(1)$ \\
\hline$C(18)$ & $24(1)$ & $31(1)$ & $20(1)$ & $-2(1)$ & $4(1)$ & $3(1)$ \\
\hline $\mathrm{C}(19)$ & $35(1)$ & $31(1)$ & $25(1)$ & $-6(1)$ & $-1(1)$ & $11(1)$ \\
\hline$C(20)$ & $30(1)$ & $29(1)$ & $22(1)$ & $-4(1)$ & $4(1)$ & $9(1)$ \\
\hline $\mathrm{C}(21)$ & $30(1)$ & $30(1)$ & $27(1)$ & $2(1)$ & $8(1)$ & $3(1)$ \\
\hline $\mathrm{C}(22)$ & $25(1)$ & $32(1)$ & $32(1)$ & $0(1)$ & $5(1)$ & $0(1)$ \\
\hline$C(23)$ & $24(1)$ & $30(1)$ & $24(1)$ & $-2(1)$ & $2(1)$ & $4(1)$ \\
\hline
\end{tabular}




\begin{tabular}{llllllc}
$\mathrm{C}(24)$ & $30(1)$ & $25(1)$ & $30(1)$ & $-1(1)$ & $6(1)$ & $4(1)$ \\
$\mathrm{C}(25)$ & $26(1)$ & $26(1)$ & $32(1)$ & $-8(1)$ & $4(1)$ & $2(1)$ \\
$\mathrm{C}(26)$ & $47(1)$ & $61(1)$ & $34(1)$ & $1(1)$ & $-11(1)$ & $-17(1)$ \\
\hline
\end{tabular}


Table C5. Hydrogen coordinates ( $\left.1^{4}\right)$ and isotropic displacement parameters $\left(\AA^{2} \mathrm{x}\right.$ $10^{3}$ ) for 62 .

\begin{tabular}{|c|c|c|c|c|}
\hline & $\mathrm{x}$ & $\mathrm{y}$ & $\mathrm{z}$ & $\mathrm{U}(\mathrm{eq})$ \\
\hline $\mathrm{H}(5 \mathrm{~A})$ & $4410(20)$ & $6330(30)$ & $8120(20)$ & $46(6)$ \\
\hline $\mathrm{H}(5 \mathrm{~B})$ & $5460(20)$ & $6600(30)$ & $9130(20)$ & $41(6)$ \\
\hline $\mathrm{H}(5 \mathrm{C})$ & $5000(20)$ & $5000(30)$ & $8880(20)$ & $48(7)$ \\
\hline$H(6 A)$ & $3960(20)$ & $6020(30)$ & $11430(20)$ & $46(6)$ \\
\hline $\mathrm{H}(6 \mathrm{~B})$ & $5220(30)$ & $6410(40)$ & $11140(30)$ & $70(9)$ \\
\hline$H(6 C)$ & $4658(19)$ & $4860(30)$ & $10943(19)$ & $37(5)$ \\
\hline $\mathrm{H}(7 \mathrm{~A})$ & $1741(18)$ & $8820(30)$ & $7215(17)$ & $30(5)$ \\
\hline $\mathrm{H}(7 \mathrm{~B})$ & $2540(17)$ & $7490(20)$ & $7124(16)$ & $24(4)$ \\
\hline $\mathrm{H}(8 \mathrm{~A})$ & $846(18)$ & $7270(30)$ & $5752(19)$ & $37(5)$ \\
\hline $\mathrm{H}(8 \mathrm{~B})$ & $950(19)$ & $5880(30)$ & $6521(19)$ & $33(5)$ \\
\hline $\mathrm{H}(11)$ & $620(18)$ & $9080(30)$ & $8980(17)$ & $32(5)$ \\
\hline $\mathrm{H}(12 \mathrm{~A})$ & $-1500(20)$ & $9150(30)$ & $8710(20)$ & $44(6)$ \\
\hline $\mathrm{H}(12 \mathrm{~B})$ & $-2230(20)$ & $8360(30)$ & $7610(20)$ & $45(6)$ \\
\hline $\mathrm{H}(12 \mathrm{C})$ & $-1860(20)$ & $7460(30)$ & $8740(20)$ & $48(6)$ \\
\hline $\mathrm{H}(13)$ & $-2065(17)$ & $7080(30)$ & $6249(16)$ & $26(4)$ \\
\hline $\mathrm{H}(14 \mathrm{~A})$ & $-1713(17)$ & $4680(30)$ & $5669(18)$ & $30(5)$ \\
\hline $\mathrm{H}(14 \mathrm{~B})$ & $-609(15)$ & $5200(20)$ & $5151(14)$ & $13(4)$ \\
\hline$H(16 A)$ & $-2710(20)$ & $9030(30)$ & $3126(19)$ & $40(6)$ \\
\hline $\mathrm{H}(16 \mathrm{~B})$ & $-3160(20)$ & $7630(40)$ & $2570(30)$ & $62(8)$ \\
\hline$H(16 C)$ & $-3428(19)$ & $8000(30)$ & $3707(18)$ & $32(5)$ \\
\hline $\mathrm{H}(17 \mathrm{~A})$ & $-530(20)$ & $8200(30)$ & $3110(20)$ & $47(6)$ \\
\hline $\mathrm{H}(17 \mathrm{~B})$ & $-170(20)$ & $6450(30)$ & $3620(20)$ & $44(6)$ \\
\hline $\mathrm{H}(17 \mathrm{C})$ & $-1120(20)$ & $6710(30)$ & $2480(20)$ & $48(7)$ \\
\hline $\mathrm{H}(18 \mathrm{~A})$ & $82(16)$ & $6240(20)$ & $9825(16)$ & $24(4)$ \\
\hline $\mathrm{H}(18 \mathrm{~B})$ & $-265(17)$ & $7810(20)$ & $10267(16)$ & $23(4)$ \\
\hline $\mathrm{H}(19 \mathrm{~A})$ & $1890(20)$ & $9410(30)$ & $11140(20)$ & $49(7)$ \\
\hline $\mathrm{H}(19 \mathrm{~B})$ & $833(18)$ & $8880(30)$ & $11744(17)$ & $27(5)$ \\
\hline $\mathrm{H}(21)$ & $3490(20)$ & $9970(30)$ & $12540(20)$ & $43(6)$ \\
\hline$H(22)$ & $4670(19)$ & $9610(30)$ & $14305(18)$ & $35(5)$ \\
\hline $\mathrm{H}(24)$ & $2790(18)$ & $5870(30)$ & $14757(19)$ & $33(5)$ \\
\hline
\end{tabular}




\begin{tabular}{lllll}
$\mathrm{H}(25)$ & $1647(18)$ & $6290(30)$ & $13026(18)$ & $33(5)$ \\
$\mathrm{H}(26 \mathrm{~A})$ & $4800(30)$ & $9500(50)$ & $16380(30)$ & $73(9)$ \\
$\mathrm{H}(26 \mathrm{~B})$ & $5550(20)$ & $8210(30)$ & $17040(20)$ & $46(6)$ \\
$\mathrm{H}(26 \mathrm{C})$ & $5880(20)$ & $8660(40)$ & $15810(20)$ & $55(7)$ \\
\hline
\end{tabular}


Table D1. Crystal data and structure refinement for $\mathbf{7 4}$.

Identification code

Empirical formula

Formula weight

Temperature

Wavelength

Crystal system

Space group

Unit cell dimensions

Volume

Z

Density (calculated)

Absorption coefficient

$\mathbf{F}(000)$

Crystal size

Theta range for data collection

Index ranges

Reflections collected

Independent reflections

Completeness to theta $=71.35^{\circ}$

Absorption correction

Max. and min. transmission

Refinement method

Data / restraints / parameters

Goodness-of-fit on $\mathrm{F}^{2}$

Final R indices [I $>2$ sigma(I)]

$\mathrm{R}$ indices (all data)

Absolute structure parameter

Largest diff. peak and hole
74

$\mathrm{C}_{15} \mathrm{H}_{20} \mathrm{O}_{5}$

280.31

$100(2) \mathrm{K}$

$1.54180 \AA$

Orthorhombic

$\mathrm{P} 2,2_{1} 2_{1}$

$a=6.9423(2) \AA$

$\alpha=90^{\circ}$.

$b=9.2387(3) \AA$

$\beta=90^{\circ}$.

$c=21.8045(7) \AA$

$\gamma=90^{\circ}$.

4

$1.331 \mathrm{Mg} / \mathrm{m}^{3}$

$0.824 \mathrm{~mm}^{-1}$

600

$0.4 \times 0.3 \times 0.1 \mathrm{~mm}^{3}$

4.05 to $71.35^{\circ}$.

$0<=h<=8,0<=k<=11,-26<=1<=26$

14673

2318 [R(int) $=0.017]$

$89.0 \%$

Semi-empirical from equivalents

1.0000 and 0.4406

Full-matrix least-squares on $\mathrm{F}^{2}$

$2318 / 0 / 185$

1.158

$\mathrm{R} 1=0.0402, \mathrm{wR} 2=0.1040$

$\mathrm{R} 1=0.0403, \mathrm{wR} 2=0.1040$

$0.0(2)$

0.385 and -0.275 e. $\AA^{-3}$ 
Table D2. Atomic coordinates ( $\times 10^{4}$ ) and equivalent isotropic displacement parameters $\left(\AA^{2} \times 10^{3}\right)$ for 74 . $U(e q)$ is defined as one third of the trace of the orthogonalized $U^{i j}$ tensor.

\begin{tabular}{|c|c|c|c|c|}
\hline & $\mathrm{x}$ & y & $z$ & $\mathrm{U}(\mathrm{eq})$ \\
\hline$O(1)$ & $7707(3)$ & $-3748(2)$ & $824(1)$ & $29(1)$ \\
\hline$O(2)$ & 9237(3) & $-2147(2)$ & $235(1)$ & $27(1)$ \\
\hline$O(3)$ & $10269(3)$ & $-1107(2)$ & $1527(1)$ & $32(1)$ \\
\hline $\mathrm{O}(4)$ & $3172(2)$ & $3351(2)$ & $1217(1)$ & $19(1)$ \\
\hline$O(5)$ & $3550(2)$ & $3476(2)$ & $2242(1)$ & $22(1)$ \\
\hline$C(1)$ & $9317(4)$ & $-572(2)$ & $164(1)$ & $23(1)$ \\
\hline$C(2)$ & 7437(3) & $-75(2)$ & $451(1)$ & $17(1)$ \\
\hline$C(3)$ & $7116(3)$ & $1463(2)$ & $659(1)$ & $13(1)$ \\
\hline$C(4)$ & $8266(3)$ & 2593(2) & $325(1)$ & $16(1)$ \\
\hline$C(5)$ & $5769(3)$ & $1677(2)$ & $1092(1)$ & $15(1)$ \\
\hline$C(6)$ & $4635(3)$ & $460(2)$ & 1393(1) & $22(1)$ \\
\hline$C(7)$ & $5163(3)$ & $-1106(2)$ & $1214(1)$ & $20(1)$ \\
\hline$C(8)$ & $7225(3)$ & $-1144(2)$ & $987(1)$ & $18(1)$ \\
\hline$C(9)$ & $8003(3)$ & $-2513(2)$ & $692(1)$ & $21(1)$ \\
\hline$C(10)$ & $8614(3)$ & $-742(2)$ & $1503(1)$ & $20(1)$ \\
\hline$C(11)$ & $5208(3)$ & $3167(2)$ & $1313(1)$ & $16(1)$ \\
\hline$C(12)$ & $5452(3)$ & $3446(2)$ & $2008(1)$ & $20(1)$ \\
\hline$C(13)$ & 2334(3) & $3966(2)$ & $1753(1)$ & $18(1)$ \\
\hline$C(14)$ & $2346(4)$ & 5593(3) & $1710(1)$ & $37(1)$ \\
\hline$C(15)$ & $367(3)$ & $3350(3)$ & $1847(1)$ & $35(1)$ \\
\hline
\end{tabular}


Table D3. Bond lengths $[\AA ̊]$ and angles $\left[^{\circ}\right]$ for $\mathbf{7 4}$.

\begin{tabular}{|c|c|c|c|}
\hline $\mathrm{O}(1)-\mathrm{C}(9)$ & $1.194(3)$ & $C(1)-C(2)-C(8)$ & $101.63(16)$ \\
\hline$O(2)-C(9)$ & $1.358(3)$ & $C(5)-C(3)-C(4)$ & $127.48(17)$ \\
\hline $\mathrm{O}(2)-\mathrm{C}(1)$ & $1.464(2)$ & $C(5)-C(3)-C(2)$ & $116.94(16)$ \\
\hline$O(3)-C(10)$ & $1.198(3)$ & $C(4)-C(3)-C(2)$ & $115.45(16)$ \\
\hline$O(4)-C(13)$ & $1.425(2)$ & $C(3)-C(5)-C(11)$ & $122.52(17)$ \\
\hline $\mathrm{O}(4)-\mathrm{C}(11)$ & $1.439(3)$ & $C(3)-C(5)-C(6)$ & $123.66(17)$ \\
\hline $\mathrm{O}(5)-\mathrm{C}(12)$ & $1.415(3)$ & $C(11)-C(5)-C(6)$ & $113.80(16)$ \\
\hline$O(5)-C(13)$ & $1.433(2)$ & $C(5)-C(6)-C(7)$ & $117.45(17)$ \\
\hline$C(1)-C(2)$ & $1.518(3)$ & $C(8)-C(7)-C(6)$ & $109.20(16)$ \\
\hline$C(2)-C(3)$ & $1.508(2)$ & $C(7)-C(8)-C(9)$ & $119.59(17)$ \\
\hline$C(2)-C(8)$ & $1.536(2)$ & $C(7)-C(8)-C(10)$ & $110.50(16)$ \\
\hline$C(3)-C(5)$ & $1.343(3)$ & $C(9)-C(8)-C(10)$ & $106.84(16)$ \\
\hline$C(3)-C(4)$ & $1.503(2)$ & $C(7)-C(8)-C(2)$ & $108.89(17)$ \\
\hline$C(5)-C(11)$ & $1.509(3)$ & $C(9)-C(8)-C(2)$ & $100.37(15)$ \\
\hline$C(5)-C(6)$ & $1.522(3)$ & $C(10)-C(8)-C(2)$ & $110.06(16)$ \\
\hline$C(6)-C(7)$ & $1.543(3)$ & $\mathrm{O}(1)-\mathrm{C}(9)-\mathrm{O}(2)$ & $121.57(19)$ \\
\hline$C(7)-C(8)$ & $1.515(3)$ & $O(1)-C(9)-C(8)$ & $129.3(2)$ \\
\hline$C(8)-C(9)$ & $1.518(3)$ & $O(2)-C(9)-C(8)$ & $109.12(16)$ \\
\hline$C(8)-C(10)$ & $1.529(3)$ & $O(3)-C(10)-C(8)$ & $124.63(19)$ \\
\hline$C(11)-C(12)$ & $1.547(2)$ & $\mathrm{O}(4)-\mathrm{C}(11)-\mathrm{C}(5)$ & $108.33(16)$ \\
\hline$C(13)-C(15)$ & $1.494(3)$ & $\mathrm{O}(4)-\mathrm{C}(11)-\mathrm{C}(12)$ & $103.30(15)$ \\
\hline \multirow[t]{2}{*}{$C(13)-C(14)$} & $1.506(3)$ & $C(5)-C(11)-C(12)$ & $115.81(16)$ \\
\hline & & $\mathrm{O}(5)-\mathrm{C}(12)-\mathrm{C}(11)$ & $104.73(15)$ \\
\hline$C(9)-O(2)-C(1)$ & $110.42(15)$ & $O(4)-C(13)-O(5)$ & $104.07(15)$ \\
\hline$C(13)-O(4)-C(11)$ & $109.19(14)$ & $O(4)-C(13)-C(15)$ & $109.44(17)$ \\
\hline$C(12)-O(5)-C(13)$ & $106.76(14)$ & $\mathrm{O}(5)-\mathrm{C}(13)-\mathrm{C}(15)$ & $108.48(17)$ \\
\hline$O(2)-C(1)-C(2)$ & $102.98(17)$ & $\mathrm{O}(4)-\mathrm{C}(13)-\mathrm{C}(14)$ & $110.20(18)$ \\
\hline$C(3)-C(2)-C(1)$ & $122.41(17)$ & $\mathrm{O}(5)-\mathrm{C}(13)-\mathrm{C}(14)$ & $111.03(18)$ \\
\hline$C(3)-C(2)-C(8)$ & $111.29(14)$ & $C(15)-C(13)-C(14)$ & $113.2(2)$ \\
\hline
\end{tabular}

Symmetry transformations used to generate equivalent atoms: 
Table D4. Anisotropic displacement parameters $\left(\AA^{2} \times 10^{3}\right)$ for 74 . The anisotropic displacement factor exponent takes the form: $-2 \pi^{2}\left[h^{2} a^{* 2} U^{11}+\ldots+2 h k a^{*} b^{*} U^{12}\right]$

\begin{tabular}{lllllll}
\hline & $\mathrm{U}^{11}$ & $\mathrm{U}^{22}$ & $\mathrm{U}^{33}$ & $\mathrm{U}^{23}$ & $\mathrm{U}^{13}$ & $\mathrm{U}^{12}$ \\
\hline $\mathrm{O}(1)$ & $32(1)$ & $14(1)$ & $42(1)$ & $-1(1)$ & $-7(1)$ & $1(1)$ \\
$\mathrm{O}(2)$ & $32(1)$ & $18(1)$ & $30(1)$ & $-5(1)$ & $7(1)$ & $8(1)$ \\
$\mathrm{O}(3)$ & $25(1)$ & $38(1)$ & $34(1)$ & $-2(1)$ & $-5(1)$ & $0(1)$ \\
$\mathrm{O}(4)$ & $16(1)$ & $28(1)$ & $14(1)$ & $-5(1)$ & $-2(1)$ & $7(1)$ \\
$\mathrm{O}(5)$ & $14(1)$ & $36(1)$ & $14(1)$ & $-4(1)$ & $0(1)$ & $2(1)$ \\
$\mathrm{C}(1)$ & $30(1)$ & $16(1)$ & $23(1)$ & $-1(1)$ & $8(1)$ & $6(1)$ \\
$\mathrm{C}(2)$ & $20(1)$ & $17(1)$ & $14(1)$ & $0(1)$ & $-1(1)$ & $-1(1)$ \\
$\mathrm{C}(3)$ & $14(1)$ & $12(1)$ & $12(1)$ & $0(1)$ & $-3(1)$ & $1(1)$ \\
$\mathrm{C}(4)$ & $18(1)$ & $16(1)$ & $15(1)$ & $1(1)$ & $5(1)$ & $3(1)$ \\
$\mathrm{C}(5)$ & $14(1)$ & $17(1)$ & $13(1)$ & $1(1)$ & $-1(1)$ & $1(1)$ \\
$\mathrm{C}(6)$ & $20(1)$ & $17(1)$ & $27(1)$ & $1(1)$ & $8(1)$ & $-2(1)$ \\
$\mathrm{C}(7)$ & $20(1)$ & $17(1)$ & $23(1)$ & $1(1)$ & $1(1)$ & $-4(1)$ \\
$\mathrm{C}(8)$ & $20(1)$ & $13(1)$ & $21(1)$ & $1(1)$ & $-2(1)$ & $-2(1)$ \\
$\mathrm{C}(9)$ & $21(1)$ & $15(1)$ & $27(1)$ & $-3(1)$ & $-8(1)$ & $1(1)$ \\
$\mathrm{C}(10)$ & $23(1)$ & $16(1)$ & $20(1)$ & $3(1)$ & $1(1)$ & $-2(1)$ \\
$\mathrm{C}(11)$ & $14(1)$ & $18(1)$ & $15(1)$ & $0(1)$ & $1(1)$ & $1(1)$ \\
$\mathrm{C}(12)$ & $15(1)$ & $26(1)$ & $18(1)$ & $-6(1)$ & $-2(1)$ & $2(1)$ \\
$\mathrm{C}(13)$ & $18(1)$ & $22(1)$ & $15(1)$ & $-6(1)$ & $0(1)$ & $3(1)$ \\
$\mathrm{C}(14)$ & $43(2)$ & $25(1)$ & $43(1)$ & $-9(1)$ & $-5(1)$ & $12(1)$ \\
$\mathrm{C}(15)$ & $16(1)$ & $62(2)$ & $26(1)$ & $-13(1)$ & $2(1)$ & $-4(1)$ \\
& & & & & & \\
\hline & & & & & & \\
\hline
\end{tabular}


Table D5. Hydrogen coordinate $\left(\times 10^{4}\right)$ and isotropic displacement parameter $\left(\AA^{2} \times 10^{3}\right)$ for 74 .

\begin{tabular}{|c|c|c|c|c|}
\hline & $\mathbf{x}$ & $y$ & $\mathbf{z}$ & $U(e q)$ \\
\hline $\mathrm{H}(1 \mathrm{~A})$ & 9385 & -299 & -265 & 27 \\
\hline$H(1 B)$ & 10416 & -168 & 379 & 27 \\
\hline $\mathrm{H}(2)$ & 6412 & -301 & 158 & 20 \\
\hline $\mathrm{H}(4 \mathrm{~A})$ & 7806 & 3538 & 435 & 24 \\
\hline $\mathrm{H}(4 \mathrm{~B})$ & 8128 & 2456 & -109 & 24 \\
\hline$H(4 C)$ & 9600 & 2507 & 436 & 24 \\
\hline $\mathrm{H}(6 \mathrm{~A})$ & 3282 & 606 & 1301 & 26 \\
\hline $\mathrm{H}(6 \mathrm{~B})$ & 4783 & 551 & 1834 & 26 \\
\hline $\mathrm{H}(7 \mathrm{~A})$ & 5022 & -1738 & 1566 & 24 \\
\hline $\mathrm{H}(7 \mathrm{~B})$ & 4303 & -1445 & 894 & 24 \\
\hline $\mathrm{H}(10)$ & 8142 & -174 & 1822 & 23 \\
\hline $\mathrm{H}(11)$ & 5918 & 3902 & 1080 & 19 \\
\hline $\mathrm{H}(12 \mathrm{~A})$ & 6193 & 2677 & 2198 & 24 \\
\hline $\mathrm{H}(12 \mathrm{~B})$ & 6097 & 4361 & 2080 & 24 \\
\hline $\mathrm{H}(14 \mathrm{~A})$ & 3651 & 5931 & 1684 & 55 \\
\hline $\mathrm{H}(14 \mathrm{~B})$ & 1744 & 5995 & 2068 & 55 \\
\hline $\mathrm{H}(14 \mathrm{C})$ & 1650 & 5890 & 1351 & 55 \\
\hline $\mathrm{H}(15 \mathrm{~A})$ & -448 & 3625 & 1510 & 52 \\
\hline $\mathrm{H}(15 \mathrm{~B})$ & -164 & 3715 & 2223 & 52. \\
\hline$H(15 C)$ & 447 & 2314 & 1867 & 52 \\
\hline
\end{tabular}


Table D6. Torsion angles [0] for $\mathbf{7 4}$.

\begin{tabular}{|c|c|c|c|}
\hline$C(9)-O(2)-C(1)-C(2)$ & $-21.8(2)$ & $C(7)-C(8)-C(9)-O(1)$ & $-37.8(3)$ \\
\hline $\mathrm{O}(2)-\mathrm{C}(1)-\mathrm{C}(2)-\mathrm{C}(3)$ & $161.20(16)$ & $C(10)-C(8)-C(9)-O(1)$ & $88.5(3)$ \\
\hline$O(2)-C(1)-C(2)-C(8)$ & $36.47(19)$ & $C(2)-C(8)-C(9)-O(1)$ & $-156.7(2)$ \\
\hline$C(1)-C(2)-C(3)-C(5)$ & $-156.39(18)$ & $C(7)-C(8)-C(9)-O(2)$ & $144.44(18)$ \\
\hline$C(8)-C(2)-C(3)-C(5)$ & $-36.2(2)$ & $C(10)-C(8)-C(9)-O(2)$ & $-89.22(19)$ \\
\hline$C(1)-C(2)-C(3)-C(4)$ & $27.3(2)$ & $C(2)-C(8)-C(9)-O(2)$ & $25.6(2)$ \\
\hline$C(8)-C(2)-C(3)-C(4)$ & $147.55(17)$ & $C(7)-C(8)-C(10)-O(3)$ & $155.17(19)$ \\
\hline$C(4)-C(3)-C(5)-C(11)$ & $-0.1(3)$ & $C(9)-C(8)-C(10)-O(3)$ & $23.6(3)$ \\
\hline$C(2)-C(3)-C(5)-C(11)$ & $-175.90(17)$ & $C(2)-C(8)-C(10)-O(3)$ & $-84.5(2)$ \\
\hline$C(4)-C(3)-C(5)-C(6)$ & $178.21(19)$ & $C(13)-O(4)-C(11)-C(5)$ & $134.42(15)$ \\
\hline$C(2)-C(3)-C(5)-C(6)$ & $2.4(3)$ & $C(13)-O(4)-C(11)-C(12)$ & $11.08(19)$ \\
\hline$C(3)-C(5)-C(6)-C(7)$ & $3.7(3)$ & $C(3)-C(5)-C(11)-O(4)$ & $122.49(19)$ \\
\hline$C(11)-C(5)-C(6)-C(7)$ & $-177.81(18)$ & $C(6)-C(5)-C(11)-O(4)$ & $-56.0(2)$ \\
\hline$C(5)-C(6)-C(7)-C(8)$ & $24.3(2)$ & $C(3)-C(5)-C(11)-C(12)$ & $-122.08(19)$ \\
\hline$C(6)-C(7)-C(8)-C(9)$ & $-170.86(17)$ & $C(6)-C(5)-C(11)-C(12)$ & $59.4(2)$ \\
\hline$C(6)-C(7)-C(8)-C(10)$ & $64.54(19)$ & $C(13)-O(5)-C(12)-C(11)$ & $-28.55(19)$ \\
\hline$C(6)-C(7)-C(8)-C(2)$ & $-56.5(2)$ & $\mathrm{O}(4)-\mathrm{C}(11)-\mathrm{C}(12)-\mathrm{O}(5)$ & $10.71(19)$ \\
\hline$C(3)-C(2)-C(8)-C(7)$ & $64.7(2)$ & $C(5)-C(11)-C(12)-O(5)$ & $-107.5(2)$ \\
\hline$C(1)-C(2)-C(8)-C(7)$ & $-163.47(16)$ & $C(11)-O(4)-C(13)-O(5)$ & $-28.6(2)$ \\
\hline$C(3)-C(2)-C(8)-C(9)$ & $-168.96(17)$ & $C(11)-O(4)-C(13)-C(15)$ & $-144.42(18)$ \\
\hline$C(1)-C(2)-C(8)-C(9)$ & $-37.09(19)$ & $C(11)-O(4)-C(13)-C(14)$ & $90.5(2)$ \\
\hline$C(3)-C(2)-C(8)-C(10)$ & $-56.6(2)$ & $C(12)-O(5)-C(13)-O(4)$ & $35.71(19)$ \\
\hline$C(1)-C(2)-C(8)-C(10)$ & $75.26(19)$ & $C(12)-O(5)-C(13)-C(15)$ & $152.17(17)$ \\
\hline$C(1)-O(2)-C(9)-O(1)$ & 179.3(2) & $C(12)-O(5)-C(13)-C(14)$ & $-82.8(2)$ \\
\hline $\mathrm{C}(1)-\mathrm{O}(2)-\mathrm{C}(9)-\mathrm{C}(8)$ & $-2.8(2)$ & & \\
\hline
\end{tabular}

